\title{
Fatty acid-binding protein as plasma marker for tissue injury
}

Citation for published version (APA):

Pelsers, M. M. A. L. (2004). Fatty acid-binding protein as plasma marker for tissue injury. [Doctoral Thesis, Maastricht University]. Universiteit Maastricht. https://doi.org/10.26481/dis.20040623mp

Document status and date:

Published: 01/01/2004

DOI:

10.26481/dis.20040623mp

Document Version:

Publisher's PDF, also known as Version of record

\section{Please check the document version of this publication:}

- A submitted manuscript is the version of the article upon submission and before peer-review. There can be important differences between the submitted version and the official published version of record.

People interested in the research are advised to contact the author for the final version of the publication, or visit the DOI to the publisher's website.

- The final author version and the galley proof are versions of the publication after peer review.

- The final published version features the final layout of the paper including the volume, issue and page numbers.

Link to publication

\footnotetext{
General rights rights.

- You may freely distribute the URL identifying the publication in the public portal. please follow below link for the End User Agreement:

www.umlib.nl/taverne-license

Take down policy

If you believe that this document breaches copyright please contact us at:

repository@maastrichtuniversity.nl

providing details and we will investigate your claim.
}

Copyright and moral rights for the publications made accessible in the public portal are retained by the authors and/or other copyright owners and it is a condition of accessing publications that users recognise and abide by the legal requirements associated with these

- Users may download and print one copy of any publication from the public portal for the purpose of private study or research.

- You may not further distribute the material or use it for any profit-making activity or commercial gain

If the publication is distributed under the terms of Article $25 \mathrm{fa}$ of the Dutch Copyright Act, indicated by the "Taverne" license above, 
Fatty acid-binding protein as plasma marker for tissue injury 
The study presented in this thesis was performed at the Cardiovascular Research Institute Maastricht

Fatty acid-binding protein as plasma marker for tissue injury

Maurice Pelsers

Thesis Maastricht University - With summary in Dutch

ISBN 90-9018161-X

Printed by: Ponsen \& Looijen B.V., Wageningen, The Netherlands.

(C) M.M.A.L. Pelsers, Maastricht, The Netherlands, 2004. All rights reserved 
Fatty acid-binding protein as plasma marker for tissue injury

\section{Proefschrift}

ter verkrijging van de graad van doctor aan de universiteit Maastricht, op gezag van Rector Magnificus, Prof.mr. G.P.M.F. Mols, volgens het besluit van het

College van Decanen, in het openbaar te verdedigen op woensdag 23 juni 2004 om 14.00 uur

door

Maurice Martinus Antonius Leonardus Pelsers

geboren op 23 januari 1968 te Elsloo (Lb) 


\section{Promotores}

Prof. dr. J.F.C. Glatz

Prof. dr. W.T. Hermens

Beoordelingscommissie

Prof. dr. M.P. van Dieijen-Visser (voorzitter)

Prof. dr. E. Heineman

Dr. Y. Pinto

Prof. dr. F. Spener (University of Münster, Germany)

Dr. P. Vos (Universiteit Nijmegen)

Financial support by the Netherlands Heart Foundation and the Dr. Ir. van de Laar Stichting for the publication of this thesis is gratefully acknowledged.

Additionally, gratitude is expressed to the Dutch Technology Foundation (project GGN 4680), HyCult biotechnology and Clindia Benelux BV for their financial support. 
De nieuwsgierigheid van een kind, als de uiteindelijke basis voor goede wetenschap, uit zich in de nooit aflatende vraag van het waarom.

Voor Inge en Lars 


\section{Contents}

Chapter 1.

General introduction and outline of the thesis

Chapter 2

Performance of fatty acid-binding protein as plasma marker for tissue injury

Chapter 3

Development of an enzyme-linked immunosorbent assay (ELISA) for hearttype fatty acid-binding protein (H-FABP)

Chapter 4

Application of the H-FABP immunoassay in animal research

Chapter 5

Influence of age, sex and day-to-day and within-day biological variation on plasma concentrations of heart-type fatty acid-binding protein and myoglobin in healthy subjects

\section{Chapter 6}

Plasma fatty acid-binding protein outperforms troponin $\mathrm{T}$ as a sensitive marker for minor myocardial injury in chronic heart failure and unstable angina

\section{Chapter 7}

Early assessment of exercise induced skeletal muscle injury using plasma fatty acid-binding protein

\section{Chapter 8}

Fatty acid-binding protein: a new biomarker of nephrotoxicity in the rat

\section{Chapter 9}

Perfusate levels of glutathione-S-transferase, alanine amino-peptidase and fatty acid-binding protein in the viability assessment of non-heart-beating donor kidneys

\section{Chapter 10}

Liver-type fatty acid-binding protein as a sensitive serum marker of acute hepatocellular damage in liver transplant recipients

\section{Chapter 11}

Intestinal-type and liver-type fatty acid-binding protein in the intestine: tissue distribution and clinical utility 
Chapter 12

Brain-type and heart-type fatty acid-binding protein in the brain: tissue distribution and clinical utility

Chapter 13

General discussion

Summary

163

Samenvatting

168

Dankwoord

174

Curriculum Vitea

178

Publicaties

179

Awards 


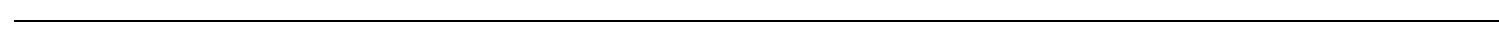




\section{General introduction and outline of the thesis}

The early detection of tissue injury, for instance due to a reduced oxygen supply (ischemia/reperfusion), poisoning, rejection, or trauma is important in stratifying patient treatment and reducing mortality and morbidity. ${ }^{(1)}$ In the clinical status such injury is often indicated by the plasma pattern of proteins that are released after cellular injury into the blood, the mechanism and characteristics of which will described in more detail in Chapter 2. The development of these so-called biochemical markers has been one of the significant changes in the field of clinical chemistry in the last decades and is now further explored by the novel possibilities of proteomics. ${ }^{(2)}$ Rapid release from injured cells and appearance in plasma, specific and high tissue content and low plasma level in normal healthy controls are the characteristics of an ideal biochemical marker protein. However, a major drawback has often been the time delay of the measurement, either due to logistics or laborious analyses. Therefore, more rapid analyses via improved automated immunoassays, less time-consuming bedside kits and biosensors, nowadays are the main improvements in so-called point-of-care testing.

In the field of cardiac injury like myocardial infarction, congestive heart failure and unstable angina ${ }^{(3)}$, biochemical markers have made their way into the coronary care unit, from the first described aspartate aminotransferase (AST) ${ }^{(4)}$, via lactate dehydrogenase ( $\mathrm{LDH}$, heart isoform) to the 'golden standard' protein creatine-kinase (CK-MB). Because this rather large protein $(84 \mathrm{kD})$ is only elevated in the blood 6 to $8 \mathrm{~h}$ after onset of symptoms, the search for earlier released proteins has led to the implementation of myoglobin $(\mathrm{Mb})$, while more heart-specific proteins are cardiac troponins $\mathrm{T}$ and I (cTnT and cTnI). Together these latter two proteins form the new marker panel for myocardial injury, next to CK-MB, electrocardiogram and history. ${ }^{(5)}$

Another protein with a high potential for sensitive and early detection of tissue injury is (cytoplasmic) fatty acid-binding protein (FABP), which is expressed in nine different isoforms, each termed after the tissue of its first detection. ${ }^{(6)}$ Heart-type fatty acid-binding protein (H-FABP) was the first FABP to be investigated as a diagnostic plasma marker. As a result of the fact that H-FABP turned out to be the earliest available marker for injured myocardium ${ }^{(7,8)}$, new studies were set up to evaluate the similar application of the specific FABP types to assess injury to skeletal muscle, kidney, liver, intestine and brain. These various studies will be described in more detail in this thesis.

In Chapter 2, a general overview of the function and clinical application of FABP is described as well as release patterns of cellular proteins after injury, assay development and point-of-care testing. The first step in evaluating the clinical utility of H-FABP was the development of a sensitive and rapid immunoassay. In Chapter 3, we describe the selection of anti-human H-FABP monoclonal antibodies (mAbs) and the development of a sandwich-type enzyme-linked immunosorbent assay (ELISA). This assay, with a total run time of $45 \mathrm{~min}$, is the most rapid, specific and sensitive H-FABP ELISA commercially available until now.

In Chapter 4, the specificity and sensitivity of the anti-human H-FABP mAbs was evaluated on tissue homogenates and purified or recombinant H-FABP from different species. It is shown that the selected mAbs recognize H-FABP in a broad range of different species and that the ELISA could be used to study fatty acid metabolism in migratory birds, effect of aging and streptozotocin-induced diabetes in rats, seasonal 
effects in hibernating squirrels and dietary variations in Atlantic salmon. The ELISA could also be used to study H-FABP as clinical marker for both detection of skeletal muscle injury in horses and myocardial injury in mice.

Cardiovascular disease is the most important cause of death in the Western society. One of the newly developing diseases with a major impact on coronary care units is congestive heart failure (also termed chronic heart failure [CHF]). Recent studies indicate that progressive deterioration of ventricular function in patients with CHF is associated with ongoing myocardial injury. ${ }^{(3)}$ However, in many patients with CHF or unstable angina pectoris (UAP) such injury is not diagnosed, because the currently used biochemical plasma markers lack sufficient sensitivity. To establish first a proper clinical reference range, Chapter 5 outlines the influence of age, sex and circadian rhythm on the biological variation of H-FABP in plasma of normal healthy controls. A cut-off value of $6 \mu \mathrm{g} / \mathrm{L}$ was established as reference value for detection of myocardial injury. In Chapter 6 , we used this reference value and compared H-FABP and cTnT as markers for minor myocardial injury during CHF and UAP. The data indicate that minor myocardial cell necrosis is detectable in a significant proportion of patients with CHF and that H-FABP is a more sensitive marker for detection of such injury than cTnT. An important finding was that H-FABP had a significant better negative prognostic value for recurrent cardiac events than cTnT.

Although H-FABP is mainly expressed in cardiomyocytes, it also occurs in much lower concentrations in skeletal muscle, kidney distal tubular cells and the brain. Chapter 7 describes the use of H-FABP as sensitive marker for exercise-induced skeletal muscle injury. Plasma H-FABP and Mb concentrations increase and decrease more rapidly than creatine kinase $(\mathrm{CK})$, indicating that both $\mathrm{H}-\mathrm{FABP}$ and $\mathrm{Mb}$ are more useful than $\mathrm{CK}$ for early detection of such injuries and for the monitoring of injury during repeated exercise bouts. In addition, the $\mathrm{Mb}$ to H-FABP ratio in plasma identifies the type of muscle injured (heart or skeletal muscle).

Chapters 8 and 9 describe the use of H-FABP for the detection of kidney injury, either due to heavy metal toxicity, administration of cyclosporin and gentamicin to rats or due to ischemia in human non-heart-beating donor kidneys destined for transplantation.

In chapter 10, the liver-type FABP (L-FABP) is evaluated as early marker for liver injury due to rejection in transplant recipients. Although the newly introduced marker glutathione-S-transferase (GST) already reduces mortality and morbidity when used in the clinical diagnosis, compared to the standard marker alanine aminotransferase $(\mathrm{ALT})^{(9)}$, L-FABP plasma levels were elevated significantly earlier than both these markers. Interestingly, L-FABP could also be used as marker for intestinal injury as outlined in Chapter 11. Intestinal FABP (I-FABP) and L-FABP are both expressed in enterocytes in the small intestine. Tissue content and clinical utility were investigated and, while tissue content of both I- and L-FABP correlated well with fatty acid uptake, elevated plasma levels of both I-FABP and L-FABP were found in patients suffering from intestinal diseases, while only L-FABP was increased in cases of purely hepatocellular injury.

A novel area for the application of FABP as biomarker for tissue injury is the field of brain injury. Chapter 12 outlines tissue contents and clinical application of two FABP types that occur in brain, namely brain-type FABP (B-FABP) and H-FABP. Both proteins appear to be more sensitive markers for brain injury than the currently used biomarkers S100B and neuron specific enolase (NSE) in patients with mild traumatic brain injury or electroconvulsive therapy. ${ }^{(10)}$ 
In Chapter 13, new insights in the application of biochemical marker proteins, especially FABP, are commented on in the general discussion. Marker characteristics, point-of-care testing, treatment stratification and future research are put in perspective to provide optimal markers for rapid and sensitive diagnoses of tissue injury.

\section{References}

1. Pelsers MMAL, Hermens WT, Glatz JFC. Performance of FABP as plasma marker of tissue injury. Clin Chim Acta 2004; in press

2. Hanash S. Disease proteomics. Nature 422:226-32.

3. Setsuta K, Seino Y, Ogawa T, Arao M, Miyatake Y, et al. Use of cytosolic and myofibril markers in the detection of ongoing myocardial damage in patients with chronic heart failure. Am J Med 2002; 13:717-22.

4. Karmen A, Wroblewski F, LaDue JS. Transaminase activity in human blood. J Clin Invest 1954;34:126-33.

5. Alpert JS, Thygesen K, Altman E, Bassand JP. Myocardial infarction redefined-A consensus document of the joint European Society of Cardiology/American College of Cardiology committee for the redefinition of myocardial infarction. J Am Coll Cardiol 2000;36:959-69.

6. Glatz JFC, Van der Vusse GJ. Cellular fatty acid-binding proteins: their function and physiological signification. Prog Lipid Res 1996;3:243-82.

7. Nakata T, Hashimoto A, Hase M, Tsuchihashi K, Shimamoto K. Human heart-type fatty acid-binding protein as an early diagnostic and prognostic marker in acute coronary syndrome. Cardiology 2003;99:96-104.

8. Glatz JFC, Van der Voort D, Hermens WT. Fatty acid-binding protein as the earliest available plasma marker of acute myocardial injury. J Clin Lig 2002;25:167-77.

9. Hughes VF, Trull AK, Gimson A, Friend PJ, Jamieson N, et al. Randomized trial to evaluate the clinical benefits of serum $\alpha$-glutathione-s-transferase concentration monitoring after liver transplantation. Transplant 1997;64:1446-52.

10. Pelsers M, Hanhoff T, van der Voort D, de Kruijk J, Twijnstra A, et al. Tissue specific types of fatty acid-binding proteins, B- and H-FABP, as novel markers for detection of brain injury. Clin Chem Lab Med 2003;41:P7.98(abstract). 
Chapter 1 


\section{Performance of fatty acid-binding proteins as plasma markers for tissue injury}

Part of this chapter will be published:

Pelsers MMAL, Hermens WT, Glatz JFC. Performance of fatty acid-binding proteins as plasma markers for tissue injury. Invited review for Clin Chim Acta, in press. 


\subsection{Abstract}

Biochemical markers have become important diagnostic and prognostic parameters in the management of patients with acute tissue injury. One of the novel and promising markers is cytoplasmic fatty acid-binding protein (FABP). This small $(15 \mathrm{kD})$ protein is involved in cellular long-chain fatty acid metabolism and is abundantly expressed in tissues with an active fatty acid metabolism like heart and liver. Following cell damage, FABP is rapidly released into the interstitium and plasma. In this review, studies in the fields of acute coronary syndromes, kidney- and liver transplantation, intestinal ischemia and brain injury are evaluated on the use of FABP as marker for tissue injury detection. Tissue contents and clinical utility of different FABP-types have been reported and indicate that an early release and the sensitive detection of tissue injury are unique features of FABP over other marker proteins.

The combined data indicate that monitoring of specific FABP types in plasma can help decrease mortality and morbidity in various clinical settings, especially in management of coronary syndromes, kidney- and liver transplantation, intestinal disease and brain injury.

\subsection{Introduction}

The presence in plasma of cellular proteins released after tissue injury or produced by malignant cells, commonly referred to as biochemical markers, is gaining more and more interest as being important in the management of patients with tissue injury due to acute ischemia/reperfusion, neurological disorders, cancer, organ rejection or trauma. Technological improvements of laboratory equipment and development of point-of-care testing have enabled bedside analysis of such proteins, allowing more rapid diagnosis and thereby promoting this development.

One of the promising new biomarker proteins is fatty acid-binding protein (FABP). This relatively small $(15 \mathrm{kD})$ cytoplasmic protein is abundantly expressed in tissues with an active fatty acid metabolism like heart and liver. ${ }^{(1,2)}$ Presently, nine distinct types have been identified, with each type showing a characteristic pattern of tissue distribution and a stable intracellular half-life of 2 to 3 days. ${ }^{(1)}$ These FABP types are named after the tissue in which they were first identified and belong to a multigene family of intracellular lipid-binding proteins. ${ }^{(1,3,4)}$ Their tertiary structure resembles a clam shell in which the ligand is bound in between the two halves of the clam by interaction with specific amino acid residues within the binding pocket, the so-called Bbarrel. ${ }^{(3,5)}$ The primary function of FABP is the facilitation of intracellular long-chain fatty acid transport ${ }^{(6)}$, while other functions include regulation of gene expression by mediating fatty acid signal translocation to peroxisome proliferator activated receptors (PPARs) ${ }^{(7)}$ and putative protection of cardiac myocytes against the detergent-like effects of locally high concentrations of long-chain fatty acids, especially during ischemia. ${ }^{(1,8)}$ The cellular expression of FABPs is regulated primarily at the transcriptional level and is responsive to changes in lipid metabolism as induced by (patho)physiological and pharmaceutical stimuli like ischemia ${ }^{(9)}$, endurance training ${ }^{(10)}$, diabetes ${ }^{(11,12)}$ hypertrophy ${ }^{(13,14)}$, and hypolipidemic drugs. ${ }^{(15)}$

Heart-type FABP (H-FABP) was first shown to be released from injured myocardium in $1988^{(16)}$, after which several studies have investigated its application as a biochemical marker ofmyocardial damage. Following the finding that H-FABP currently is the earliest available and probably most sensitive marker for injured myocardium ${ }^{(17,18)}$, 
additional studies were set up to evaluate the application of this and other FABP types for the monitoring of different tissue injury. In this paper we review (i) the current status of specific assays for FABP determination, (ii) the clinical application of plasma FABP determination for monitoring cardiac, skeletal muscle, kidney, liver, intestinal and brain injury, in comparison with currently used markers of tissue damage, and finally, (iii) perspectives on further developments in this field.

\subsection{Assays for FABP}

Mono- and polyclonal antibodies were raised against different types of FABP and both immunohistochemical and immunological assays were developed to measure tissue contents and plasma/serum and urine concentrations of specific FABP types. ${ }^{(19-30)}$ In order to develop a robust assay, monoclonal antibodies are preferred due to stability in production and specificity in epitope mapping. For research purposes, mono- and polyclonal antibodies are mainly applied in enzyme-linked immunosorbent assays (sandwich ELISAs), while in clinical practice they are used in diagnostic tests performed either on automated analysers or in semi-quantitative lateral flow assays.

\subsubsection{Development of immunoassays for FABP}

For H-FABP, polyclonal antibodies were first used in ELISAs to study the role of FABP in fatty acid metabolism in the rat ${ }^{(28,29,31)}$, pig $^{(32)}$, cattle $^{(33)}$, birds $^{(34)}$, Antarctic icefish $^{(35)}$, and locust ${ }^{(36)}$, or the application of FABP as clinical plasma biomarker in man in retrospective studies. ${ }^{(37-39)}$. Subsequently, the application of hybridoma technology supplied monoclonal antibodies (mAbs) as new and continuous sources of more robust clinical diagnostica. ${ }^{(40)}$ However, anti-human H-FABP mAbs were also applied in sandwich-type ELISAs ${ }^{(20,22,41)}$ such as a one-step ELISA with a total performance time of 45 min. ${ }^{(19,21)}$

To determine liver-type FABP (L-FABP) in human tissue and plasma, recently two groups have developed a sandwich ELISA, using recombinant L-FABP. ${ }^{(42,43)}$ For intestinal-type FABP (I-FABP) ELISAs specific for either rat- or human I-FABP have been developed. ${ }^{(44-47)}$ The latest development in clinical use of FABP is the detection of brain injury. For this purpose, a sandwich-type ELISA for brain-type FABP (B-FABP) was developed using affinity purified polyclonal antibodies raised against recombinant human B-FABP. ${ }^{(48)}$ An overview of the developed assays and their main characteristics is given in Table 2.1

\subsubsection{Specificity and sensitivity}

The specificity of the reported immunochemical assays for FABP generally is very high, because essentially no cross-reactivity of the used poly- or monoclonal antibodies (pAbs and mAbs, respectively) with other FABP types was observed. ${ }^{(19,20,44,47-49)}$ However, interspecies cross-reactivity is usually observed. For instance, the anti H-FABP mAbs generated by Roos et al. ${ }^{(19,49)}$ against human H-FABP cross-reacted with the H-FABPs from rat, mice, goose, horse, salmon, squirrel, crow, and starling, showing a crossreactivity between 5 and $66 \% .{ }^{(50-53)}$ Chapter 4 describes the use of the H-FABP ELISA in animal research in more detail.

For clinical application, it is noteworthy to mention that generally no differences were observed in performance of the FABP immunoassay among serum, and EDTA-, 
heparin- and citrated plasma. ${ }^{(21,54)}$ In general, samples need to be diluted at least 2 to 5 fold to prevent matrix effects. Recombinant H-FABP reacts immunochemically equivalent to the tissue-derived protein and is therefore commonly applied as standard in immunoassays. ${ }^{(19,49)}$ H-FABP appears a very stable protein as both plasma samples and recombinant protein solutions can be subjected to repeated freezing/thawing at least 8 times without loss of immunoreactivity. ${ }^{(21)}$ Samples could also be stored (at least) for 2 years at $-80^{\circ} \mathrm{C} .^{(55)}$ The intra- and interassay variation of a number of FABP assays has been evaluated with low and high standards of the calibration range. All assays showed an intra-assay variation (low and high calibrator) $<10 \%$ and an interassay-variation (low and high calibrator) $<15 \%$. No data have been reported about possible endogenous and exogenous interfering substances or an altered detection of H-FABP after hemolysis. Both sensitivity and specificity of the one-step human H-FABP ELISA described by Wodzig et al. ${ }^{(21)}$ were comparable with those of the two-step ELISA developed by Okhura et al. ${ }^{(20)}$

Table 2.1 Overview of reported specific immunoassays for human FABP types and their main characteristics

\begin{tabular}{|c|c|c|c|c|c|c|c|}
\hline $\begin{array}{l}\text { Type- } \\
\text { FABP }\end{array}$ & $\begin{array}{l}\text { Year } \\
\text { (Ref) }\end{array}$ & Test & $\begin{array}{c}\text { Test } \\
\text { principle }\end{array}$ & $\begin{array}{c}\text { Assay } \\
\text { time } \\
\text { (min) }\end{array}$ & $\begin{array}{c}\text { Calibration } \\
\text { range } \\
(\mu \mathrm{g} / \mathrm{L})\end{array}$ & $\begin{array}{l}\text { Detection } \\
\operatorname{limit}(\mu \mathrm{g} / \mathrm{L})\end{array}$ & $\begin{array}{c}\text { Reference } \\
\text { value } \\
\text { ( } \mu \mathrm{g} / \mathrm{L})\end{array}$ \\
\hline \multirow[t]{6}{*}{ Heart } & $\begin{array}{c}1996 \\
(21,27)\end{array}$ & $\begin{array}{l}\text { ELISA } \\
\text { (mAb) }\end{array}$ & $\begin{array}{l}\text { Direct non- } \\
\text { competitive }\end{array}$ & 45 & $0-60$ & 0.3 & 6 \\
\hline & $\begin{array}{c}1995 \\
(17,20)\end{array}$ & $\begin{array}{l}\text { ELISA } \\
\text { (mAb) }\end{array}$ & $\begin{array}{l}\text { Direct non- } \\
\text { competitive }\end{array}$ & 120 & $0-250$ & 1.25 & 6.1 \\
\hline & $\begin{array}{l}1999 \\
(57)\end{array}$ & $\begin{array}{l}\text { ELISA } \\
\text { (mAb) }\end{array}$ & $\begin{array}{l}\text { Direct non- } \\
\text { competitive }\end{array}$ & - & $0-300$ & 0.1 & 6 \\
\hline & $\begin{array}{c}1991 \\
(39)\end{array}$ & $\begin{array}{l}\text { ELISA } \\
\text { (pAb) }\end{array}$ & Competitive & - & & 1.0 & - \\
\hline & $\begin{array}{l}1998 \\
(40)\end{array}$ & $\begin{array}{l}\text { Latex } \\
\text { (mAb) }\end{array}$ & $\begin{array}{l}\text { Direct non- } \\
\text { competitive }\end{array}$ & 10 & $0-150$ & 1.1 & - \\
\hline & $\begin{array}{l}2000 \\
\text { (63) }\end{array}$ & $\begin{array}{c}\text { Sandwich } \\
\text { immuno } \\
\text { assay }\end{array}$ & - & - & - & - & 12 \\
\hline \multirow[t]{2}{*}{ Liver } & $\begin{array}{l}1999 \\
(42)\end{array}$ & $\begin{array}{l}\text { ELISA } \\
(\mathrm{mAb})\end{array}$ & - & - & - & 0.1 & - \\
\hline & $\begin{array}{c}2002 \\
(43)\end{array}$ & $\begin{array}{l}\text { ELISA } \\
(\mathrm{mAb})\end{array}$ & $\begin{array}{l}\text { Direct non- } \\
\text { competitive }\end{array}$ & 240 & $0-20$ & 0.1 & 17 \\
\hline \multirow[t]{4}{*}{ Intestinal } & $\begin{array}{c}2002 \\
(46)\end{array}$ & $\begin{array}{l}\text { ELISA } \\
\text { (pAb) }\end{array}$ & $\begin{array}{l}\text { Direct non- } \\
\text { competitive }\end{array}$ & 180 & $0-4$ & 0.1 & 0.1 \\
\hline & $\begin{array}{c}2003 \\
(47)\end{array}$ & $\begin{array}{l}\text { ELISA } \\
\text { (pAb) }\end{array}$ & $\begin{array}{l}\text { Direct non- } \\
\text { competitive }\end{array}$ & 240 & $0-5$ & 0.1 & 0.1 \\
\hline & $\begin{array}{l}1997 \\
(45)\end{array}$ & $\begin{array}{c}\text { RIA } \\
(\mathrm{pAb})\end{array}$ & - & - & - & 1.87 & 1.87 \\
\hline & $\begin{array}{c}1996 \\
(61)\end{array}$ & & - & - & - & 20 & 65 \\
\hline Brain & $\begin{array}{c}2003 \\
(48)\end{array}$ & $\begin{array}{l}\text { ELISA } \\
\text { (pAb) }\end{array}$ & $\begin{array}{l}\text { Direct non- } \\
\text { competitive }\end{array}$ & 180 & $0-1000$ & 5 & 5 \\
\hline
\end{tabular}


The detection limit of the published assays ranges from $0.3 \mu \mathrm{g} / \mathrm{L}$ (H-FABP) ${ }^{(11)}$ to $5 \mu \mathrm{g} / \mathrm{L}$ $(\mathrm{B}-\mathrm{FABP})^{(48)}$ while the calibration curve ranges from 0 to $4 \mu \mathrm{g} / \mathrm{L}$ in the L-FABP assay ${ }^{(42)}$ to $0-12 \mu \mathrm{g} / \mathrm{L}$ in the H-FABP assay. ${ }^{(21)}$ These ranges suggest the feasibility of improving the present assays with a relatively high detection limit into more sensitive assays that also show a wider measuring range.

\subsubsection{Reference interval}

The clinical utility of a biochemical marker for tissue injury detection depends on several aspects. An optimal biomarker would show a high tissue content in specific cells, a rapid release out of damaged cells resulting in an early appearance in the blood, and low levels in plasma/serum or urine of healthy individuals. Each of these parameters would contribute to a high sensitivity and specificity of the marker. Proper interpretation of plasma levels of biochemical markers for clinical diagnosis is dependent especially on the establishment of a reference interval. Moreover, differences in reported specificity and sensitivity of biomarkers are often due to an improperly selected pool of healthy donors or non-disease specific patients for establishing a reference interval.

Many clinical investigators have used healthy individuals to study these reference values. In general, the $95 \%$ confidence interval (mean+2SD) is used to express the clinical cut-off value, or reference value, although the tendency nowadays is to use the $99 \%$ confidence interval (mean+3SD). As FABP is rapidly cleared from the circulation by the kidneys, relatively low reference values are maintained in plasma. Several studies reported comparable FABP normal values. Tanaka et al. ${ }^{(39)}$ detected values of H-FABP in serum and urine between 0 and $2.8 \mu \mathrm{g} / \mathrm{L}(\mathrm{n}=86)$, Wodzig et al. found a mean value of 1.5 $\mu \mathrm{g} / \mathrm{L}(\mathrm{n}=88)^{(21)}$, Sorichter et al. ${ }^{(56)}$ reported a mean value of $1.9 \mu \mathrm{g} / \mathrm{L}(\mathrm{n}=62)$, and Pelsers et al. reported $1.5 \mu \mathrm{g} / \mathrm{L}(\mathrm{n}=312) .{ }^{(27)}$ Importantly, both age and sex significantly influence H-FABP normal values. ${ }^{(27)}$ A significantly $(p<0.005)$ higher plasma H-FABP concentration was found in men than in women, together with a significant increase $(p<0.001)$ during aging, from 20 to 70 years, and a significant $(p<0.005)$ higher concentration in the night as a result of a decreased glomular filtration rate. ${ }^{(27)}$ In view of a $95 \%$ confidence interval of 2.5 to $5.9 \mu \mathrm{g} / \mathrm{L}^{(27)}$, a reference value of $6 \mu \mathrm{g} / \mathrm{L}$ for myocardial injury has been proposed independently by Pelsers et al. ${ }^{(27)}$, Katruhka et al. ${ }^{(57)}$, Pagani et al. ${ }^{(58)}$ and Nakata et al. ${ }^{(17)}$

Pelsers and co-workers studied plasma H-FABP in a group of 312 healthy blood donors $^{(27)}$, and in a subset of 80 donors (40 males, 40 females) also investigated the plasma reference interval of L-FABP, B-FABP and I-FABP. ${ }^{(43,46,47)}$ No influence of age or sex was observed for L-FABP in plasma. ${ }^{(43)}$ However, due to a decrease in glomular filtration rate, L-FABP plasma concentrations were significantly $(p<0.01)$ higher during the night. In view of the normal value of $9.5 \pm 3.6 \mu \mathrm{g} / \mathrm{L}$ and the $95 \%$ confidence interval of 4.8 to $16.9 \mu \mathrm{g} / \mathrm{L}$, the reference value for liver injury was set at $17 \mu \mathrm{g} / \mathrm{L}{ }^{(43)}$

Three studies reported intestinal-type FABP being undetectable in plasma of healthy individuals ${ }^{(47,59.60)}$, while one study reported a relatively high I-FABP plasma concentration of up to $65 \mu \mathrm{g} / \mathrm{L} .{ }^{(61)}$ Most likely, this latter high value relates to different properties of the (recombinant) calibrator of the assay used because the reported detection limit of the assay was as high as $20 \mu \mathrm{g} / \mathrm{L} .{ }^{(61)}$ For I-FABP, the reference value was set by two groups of investigators at $0.1 \mu \mathrm{g} / \mathrm{L}$ as mean $+2 \mathrm{SD}$ of the detection limit $(0.05 \mu \mathrm{g} / \mathrm{L})$ of the immunoassay. ${ }^{(46,47)}$

Brain-type FABP (B-FABP) also could not be detected in plasma of healthy individuals. ${ }^{(48)}$ Because as yet, there is only a single report on plasma B-FABP 
concentrations, the reference value was also set at the mean+2SD of the detection limit of the immunoassay to amount to $5 \mu \mathrm{g} / \mathrm{L}$.

Table 2.2 gives an overview of currently agreed reference values, and the influence of sex and circadian rhythm on plasma concentrations of selected FABP types in healthy individuals. In general, the performance of FABP as plasma marker for tissue injury can be increased by repeated or even continuous measurement of plasma concentrations. This will be discussed in more detail in section 2.5.2.

Table 2.2 Influence of sex and circadian rhythm on plasma FABP concentrations

\begin{tabular}{|l|l|l|l|l|}
\hline & \multicolumn{4}{|c|}{ Plasma FABP concentration $(\boldsymbol{\mu g} / \mathbf{L})$} \\
\hline & \multicolumn{1}{|c|}{ H-FABP } & \multicolumn{1}{|c|}{ L-FABP } & I-FABP & B-FABP \\
\hline Men & $1.6(1.3-1.9)$ & $9.8(8.2-12.1)$ & $<0.1$ & $<5.0$ \\
\hline Women & $1.4(1.0-1.8)$ & $8.5(7.1-11.1)$ & $<0.1$ & $<5.0$ \\
\hline Daytime (09.30-17.00 $\mathbf{~})$ & $0.8(0.5-1.0)$ & $6.9(5.0-7.1)$ & $<0.1$ & $<5.0$ \\
\hline Evening (17.00-01.00 $\mathbf{h})$ & $0.9(0.6-1.3)$ & $5.9(4.8-6.6)$ & $<0.1$ & $<5.0$ \\
\hline Night $\mathbf{( 0 1 . 0 0 - 0 9 . 3 0 ~} \mathbf{~})$ & $1.1(0.7-1.5)^{\star}$ & $10.2(7.9-11.7)^{\star}$ & $<0.1$ & $<5.0$ \\
\hline Reference value & $6.0(27.57,58)$ & $17.0(43)$ & $0.1(46,47)$ & $<5.0(48)$ \\
\hline
\end{tabular}

\subsubsection{Point-of-care testing}

The start of treatment of a patient is very often hampered by a delayed availability of clinical parameters due to logistic reasons or time-consuming assays. A rapid diagnosis of the clinical status of a patient can be facilitated markedly by rapid assays. Therefore, point-of-care (POC) testing, also termed as bedside- or near patient testing, is becoming an important tool in decreasing the time to start treatment. Especially in acute coronary syndromes, the minimization of delay before start of treatment is expected to become a major component in the disease management, as discussed by Azzazy et al. ${ }^{(62)}$ POC testing can be achieved by applying small hand-held devices in the Emergency Department, Intensive Care, or even ambulances. Also, time-consuming assays in the clinical laboratory should be replaced by more rapid, but still specific and sensitive assays.

At present, more rapid detection systems then the currently used manual sandwich ELISAs are being developed for H-FABP. This FABP type is in focus because rapid measurement of H-FABP in plasma of patients entering the Emergency Department is of great value for detection or exclusion of acute myocardial infarction (AMI), for detection of a re-infarction, and for estimation of the extent of tissue injury induced by ischemia (see section 2.5.2). The rapid assays include an automated sandwich immunoassay by Ghani et al. ${ }^{(63)}$ and a micro-particle enhanced immunoassay described by Robers et al. ${ }^{(40)}$ This latter, fully automated latex-agglutination assay (performed by using a COBAS ${ }^{\circledR}$ MIRA Plus analyzer (Hoffmann-La Roche Ltd) uses carboxylated latex particles on which three monoclonal anti-human H-FABP antibodies are coated, each recognizing a different epitope. ${ }^{(19)}$ With a total performance time of $10 \mathrm{~min}$, a detection limit of 1.1 $\mu \mathrm{g} / \mathrm{L}$, a calibration curve ranging up to $2400 \mu \mathrm{g} / \mathrm{L}$ post-dilution and an intra- and interassay variation of $<7 \%$ and $<11 \%$ respectively, this assay currently is the most reliable and fastest method for improved cardiac marker POC testing of H-FABP in a clinical laboratory setting. ${ }^{(40)}$ Unfortunately, the assay is not yet commercially available. 
Semi-quantitative lateral-flow assays are also being applied for POC testing of $\mathrm{H}$ FABP, as described by Chan et al. ${ }^{(64,65)}$ and Watanabe et al. ${ }^{(66)}$, and are presently commercially available. These whole blood tests which can detect H-FABP 1 to $3 \mathrm{~h}$ after acute coronary syndrome, and with a $15 \mathrm{~min}$ duration of analysis, provide an answer of either normal or elevated H-FABP above a clinical reference value set at $6 \mu \mathrm{g} / \mathrm{L}$ after myocardial injury. However, low assay stability, inter-observer differences in interpretation of color development, and the inability to discriminate between low and high elevated H-FABP values could be major drawbacks of these tests. More quantitative plasma or whole blood tests, using electrochemical immunosensors ${ }^{(67-70)}$ or precipitation ellipsometry $^{(71)}$, have been developed but these too are not yet commercially available.

\subsection{Tissue content and distribution of FABP types}

Cytoplasmic FABPs have been detected in virtually all human tissues. Initially, FABPs from kidney ${ }^{(72)}$, mammary gland ${ }^{(25)}$ and skeletal muscle ${ }^{(28)}$ each were regarded as distinct FABP types, but later were identified as already existing types. ${ }^{(1)}$ H-FABP and L-FABP are the main types showing a multi-tissue expression. H-FABP is abundantly expressed in cardiomyocytes, but to a lesser extent also in skeletal muscle ${ }^{(32,73)}$, smooth muscle cells of the intestinal tract ${ }^{(47)}$, distal tubular cells of the kidney ${ }^{(74)}$, and specific parts of the brain. ${ }^{(48,75,76)}$ L-FABP is mainly expressed in hepatocytes ${ }^{(43)}$, but also in jejunal and ileal enterocytes $^{(47,77,78)}$, colonocytes and proximal tubular cells of the kidney. ${ }^{(72,74,79)}$. Due to this multi-tissue expression, several tissues contain more than one type of FABP either because of various cell species in one tissue or of co-expression of different FABP types in a single cell. ${ }^{(77,78)}$ Interestingly, in brain and in the intestinal tract, the tissue specifictypes are expressed to a lower extent than the co-expressed FABP types. An overview of tissue protein content of the different FABP types is presented in Table 2.3.

Table 2.3 Overview of reported tissue content of different human FABP types in heart, skeletal muscle, intestine, liver and brain.

\begin{tabular}{|l|l|c|c|c|c|}
\hline \multicolumn{1}{|c|}{ Tissue } & \multicolumn{1}{|c|}{ Subtype } & $\begin{array}{c}\text { H-FABP } \\
(\boldsymbol{\mu g} / \mathbf{g} \mathbf{w w})\end{array}$ & $\begin{array}{c}\text { L-FABP } \\
(\boldsymbol{\mu g} / \mathbf{g} \mathbf{w w})\end{array}$ & $\begin{array}{c}\text { I-FABP } \\
(\boldsymbol{\mu g} / \mathbf{g} \mathbf{~ w w})\end{array}$ & $\begin{array}{c}\text { B-FABP } \\
(\boldsymbol{\mu g} / \mathbf{g} \mathbf{w w})\end{array}$ \\
\hline Heart (13) & Epicardial & 540 & - & - & - \\
\hline & Midcardial & 600 & - & - & - \\
\hline & Endocardial & 550 & - & - & - \\
\hline Skeletal muscle $^{(73)}$ & & 173 & - & - & - \\
\hline Liver $^{(49)}$ & & - & 2700 & - & - \\
\hline Small intestine $^{(47)}$ & Duodenum & 3.5 & 124 & 2.22 & - \\
\hline & Jejunum & 4.9 & 198 & 4.79 & - \\
\hline & lleum & 3.2 & 58 & 1.04 & - \\
\hline & Colon & 2.7 & 26 & 0.27 & - \\
\hline & Frontal lobe & 26.3 & - & - & 3.1 \\
\hline & Temporal lobe & 31.9 & - & - & 2.2 \\
\hline & Occipital lobe & 21.2 & - & - & 1.0 \\
\hline & Striatum & 30.6 & - & - & 0.8 \\
\hline & Pons & 39.5 & - & - & 2.0 \\
\hline & cerebellum & 16.2 & - & - & 2.8 \\
\hline
\end{tabular}




\subsection{Clinical utility of FABP in comparison with other tissue injury markers}

\subsubsection{Release pattern of cellular proteins following tissue injury.}

Since the 1950's, the appearance of cellular proteins in plasma has been used as a diagnostic tool for assessment of organ damage. When ischemia persists, many affected cells will become irreversibly injured. This is characterized by disruption of the cell membrane and leakage of cellular constituents like cytoplasmic and cytoskeletal proteins into the circulation. Soluble cytoplasmic proteins are released simultaneously, but structural proteins first need to be liberated from the structural matrix or degraded, and therefore often appear later in the circulation. From injured cardiac myocytes, small proteins will diffuse more rapidly than large proteins through the interstitial space via the endothelial clefts into the vascular space (Fig. 2.1). The size of these endothelial clefts is variable, from large clefts in the liver to smaller pores in heart, skeletal muscle and finally to impermeability in brain (blood-brain barrier). As a result, the diffusion rate and time of appearance of the released proteins into the circulation also differ. The smaller the clefts, the more large protiens will reach the circulation via the lymph flow. Finally, these proteins will be eliminated from plasma by either hepatic endocytosis or renal clearance. Therefore, the time course of the plasma concentration of these marker proteins is not only dependent on the time course of the disease, but also on the molecular size and distribution over extravascular compartments, and on the rate of elimination from plasma. ${ }^{(80)}$

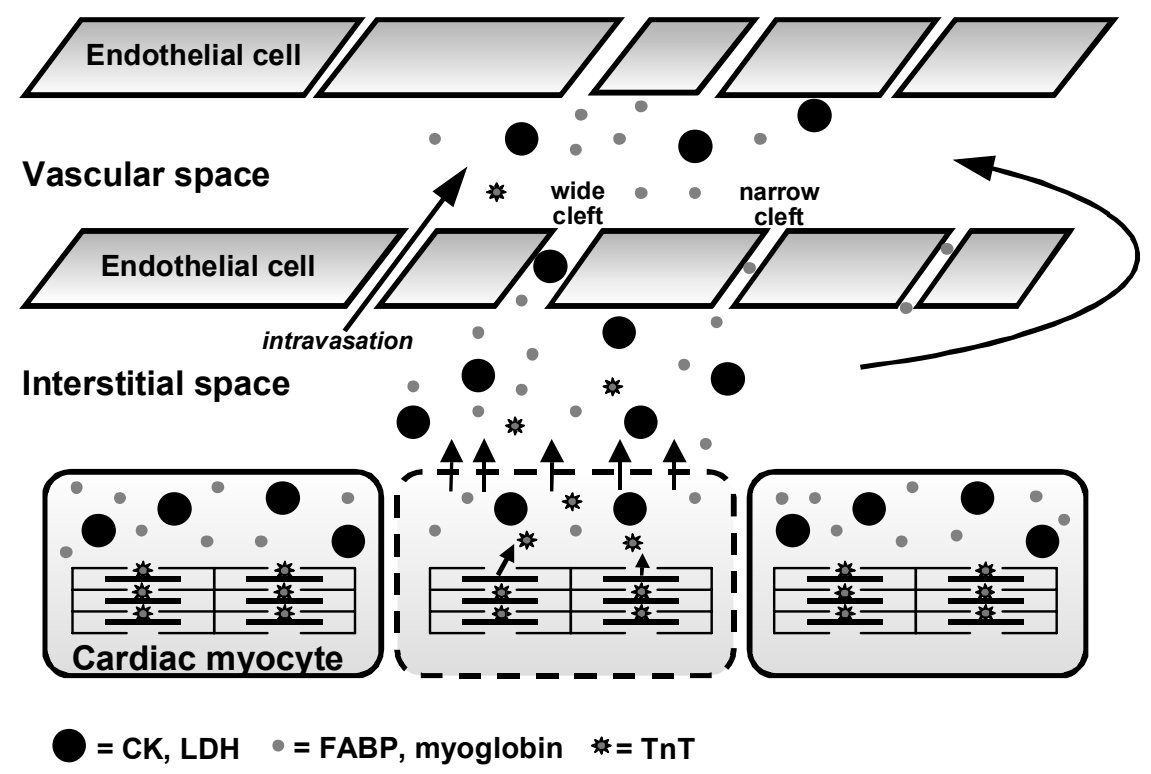

Figure 2.1 Schematic presentation of the possible transport routes of protein released from damaged tissue cells to the plasma compartment, as exemplified for cardiac myocytes. Small proteins, such as FABP and myoglobin, rapidly cross the endothelial cell barrier, while larger proteins such as creatine kinase (CK) and lactate dehydrogenase (LDH) have a longer diffusion time. Structurally bound proteins (such as the troponins) first must be dissociated from the myofibrillar matrix before they can be released into the interstitial space. (Adapted from reference 195 with permission). 


\subsubsection{Myocardial injury}

The most intensively studied example to highlight the benefits of biochemical markers is the heart. Already in the early 70's, the World Health Organization introduced a combination of two out of three characteristics as definition of an acute myocardial infarction (AMI): an electrocardiogram involving the development of Q-waves, typical symptoms (i.e., chest discomfort) and an elevated plasma level of cardiac enzymes. ${ }^{(81)}$ In 2000, AMI was redefined ${ }^{(82)}$, with increased importance on the use of biochemical markers. When ischemia of the heart occurs after the formation of a thrombus on a ruptured atherosclerotic plaque (see Chapter 13), rapid reperfusion of the occluded coronary arteries by either thrombolytic therapy (streptokinase or tissue plasminogenactivator) or percutaneous coronary interventions (PCI), reduces mortality significantly. ${ }^{(83)}$ Ischemia-reperfusion injury leads to accelerated release of cytoplasmic and structural proteins into the bloodstream ${ }^{(84)}$, which allows earlier diagnosis of the severity of the injury by the amount of elevated plasma levels of these proteins. Creatine kinase isoenzyme MB (CK-MB) has been the standard cardiac plasma marker for a long time, but currently more cardiac specific proteins like cardiac troponin $\mathrm{T}$ (cTnT) and troponin I (cTnI) are being advised as new plasma markers ${ }^{(82)}$ for the indication of cardiac cell death.

The potential of H-FABP as marker for myocardial injury has been reported by several groups. ${ }^{(18,22,37,39,85)}$ The characteristics of the release of H-FABP from injured myocardium closely resemble those of myoglobin. As an example, Fig. 2.2 shows mean plasma release curves of H-FABP, myoglobin, and for comparison, cTnT, for 15 AMI patients, treated with reperfusion therapy, from whom blood samples were obtained frequently during the first $24 \mathrm{~h}$ of hospitalization. ${ }^{(86)}$ In patients treated with standard thrombolytic therapy after AMI, peak plasma concentrations of H-FABP and myoglobin are reached at about $4 \mathrm{~h}$ after first symptoms (Fig. 2.2), whereas for creatine kinase (CK or CK-MB) this takes about $12 \mathrm{~h}$, and for lactate dehydrogenase (LDH) about $20 \mathrm{~h}^{(55)}$ Furthermore, plasma H-FABP and myoglobin return to their respective reference ranges already within $24 \mathrm{~h}$ after AMI, enhancing the usefulness of both markers for the assessment of a recurrent infarction. ${ }^{(73)}$ However, if no thrombolytic therapy is administered, the H-FABP plasma level returns to normal only after $36 \mathrm{~h}^{\left({ }^{(8)}\right)}$ The release of myofibrillar proteins cTnT and cTnI from injured myocardium follows a different pattern with elevated plasma concentrations occurring from approximately $8 \mathrm{~h}$ up to more than 1 week after infarction. ${ }^{(88,89)}$ Therefore, the so-called diagnostic window of the various proteins differs considerably and this is sometimes obscured by the use of hospital admission time, instead of onset of first symptoms, in studies validating the clinical use of H-FABP, myoglobin, cTnT and cTnI. ${ }^{(63)}$

\section{Early diagnosis of AMI}

Several studies have now confirmed that H-FABP is an excellent plasma marker for the early differentiation of patients with and those without AMI, with better performance than myoglobin. Table 2.4 lists the results of the five major studies reported to date that compared the diagnostic performance of H-FABP with that of the established early marker myoglobin in patients admitted to hospital with chest pain suggestive of AMI. Table 2.4 shows that in each study, the area under the receiver operating characteristic (ROC) curve, constructed for the admission blood samples from all patients, was found significantly greater for H-FABP than for myoglobin, indicating a superior performance of H-FABP. 

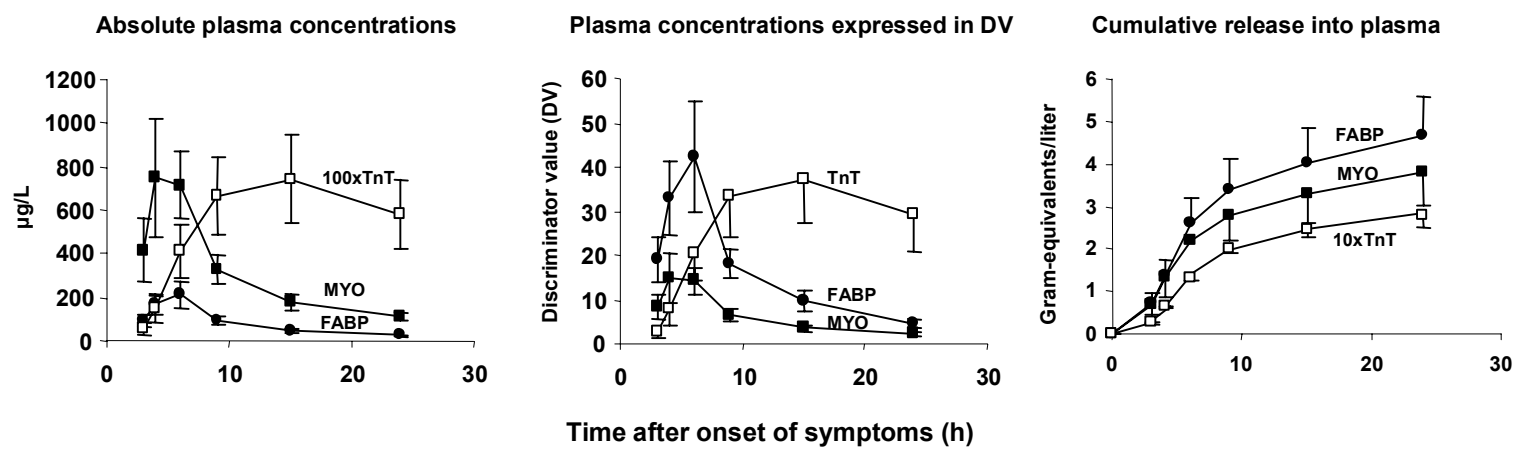

Figure 2.2 Mean plasma concentrations of $\operatorname{FABP}(\bullet)$, Myoglobin $(\mathrm{Mb})(\boldsymbol{\bullet})$, and troponin $\mathrm{T}(\mathrm{TnT})$ $(\square)$ as a function of time after acute myocardial infarction (AMI) for a subset of 15 patients who were treated successfully with reperfusion therapy and from whom serial blood samples were obtained up to $24 \mathrm{~h}$ after onset of symptoms. The data are presented as plasma concentrations in $\mu \mathrm{g} / \mathrm{L}$ (left panel) or relative to the respective reference value for FABP $(6 \mu \mathrm{g} / \mathrm{L}), \mathrm{MB}(60 \mu \mathrm{g} / \mathrm{L})$, and TnT $(0.1 \mu \mathrm{g} / \mathrm{L})$ (middle panel). The mean cumulative release expressed in gram equivalents ( $\mathrm{g}$ eq) of healthy myocardium per liter of plasma (infarct size) is also given (right panel). Data refer to mean \pm SEM. (Adapted from reference 18 with permission, but cumulative release of CTnT has been adjusted due to new clearance rates of fragmented cTnT. ${ }^{(196)}$

Table 2.4 Diagnostic performance of plasma FABP and myoglobin in detection of AMI: a comparison of several studies.

\begin{tabular}{|c|c|c|c|c|c|c|c|c|}
\hline \multirow[t]{2}{*}{ reference $^{\text {(ref) }}$} & \multirow{2}{*}{$\begin{array}{c}\text { Number } \\
\text { of } \\
\text { centers }\end{array}$} & \multirow{2}{*}{$\begin{array}{c}\text { Number } \\
\text { of } \\
\text { patients }\end{array}$} & \multirow{2}{*}{$\begin{array}{l}\text { Patients } \\
\text { with } \\
\text { AMI (\%) }\end{array}$} & \multicolumn{2}{|c|}{ Admission time } & \multicolumn{3}{|c|}{ Area under ROC curve } \\
\hline & & & & Mean (h) & Range (h) & FABP & Mb & $\mathbf{P}^{*}$ \\
\hline Ishii $1997^{(197)}$ & 1 & 165 & 60 & 3.5 & $3-12$ & 0.898 & 0.782 & $<0.01$ \\
\hline Glatz 1997(90) & 4 & 312 & 54 & 3.3 & $1.5-8$ & 0.901 & 0.824 & $<0.001$ \\
\hline Okamoto $2000^{(91)}$ & 1 & 189 & 74 & 4.0 & $0-12$ & 0.921 & 0.843 & $<0.05$ \\
\hline Ghani $2000^{(63)}$ & 3 & 460 & 21 & $\sim 3^{* *}$ & $3-7^{* *}$ & 0.800 & 0.730 & Not given \\
\hline Nakata 2003 (17) & 8 & 133 & 44 & $\sim 6$ & $0-48$ & 0.936 & 0.862 & Not given \\
\hline
\end{tabular}

The performance of these two early plasma markers is given for measurements made in admission blood samples taken from patients entering the hospital with chest pain suggestive of AMI. $\mathrm{P}^{*}$ values comparing the areas under the ROC curve for FABP and myoglobin. ${ }^{* *}=0-4 \mathrm{~h}$ period with added hospital delay of approximately $3 \mathrm{~h}$ (see text). Abbreviations: AMI=acute myocardial infarction, ROC curve=receiver operating characteristics curve, FABP=fatty acidbinding protein

The analysis of subgroups of patients showed even a better performance of H-FABP compared with myoglobin, if the patients were admitted earlier after onset of symptoms. ${ }^{(3,90,91)}$ For instance, in the EUROCARDI multi-center study ${ }^{(90)}$, the subgroup of patients admitted 0-3 $\mathrm{h}$ after onset of symptoms showed an area under the ROC-curve of 0.845 for H-FABP and 0.717 for myoglobin (Fig. 2.3), while the subgroup of patients admitted 3-6 $\mathrm{h}$ after onset of symptoms showed 0.945 for H-FABP and 0.892 for myoglobin. These observations extent similar previous results. ${ }^{(85,92-94)}$ 
To further improve the monitoring of cardiac tissue injury, the concept of more frequent or continuous measurement of H-FABP in plasma has been applied. By using two plasma samples, one at admission and the other 1 to $2 \mathrm{~h}$ after admission, sequential FABP monitoring may permit diagnosing patients suspected of AMI already 1 to $2 \mathrm{~h}$ after admission. Renneberg et al. ${ }^{(95)}$ reported a $100 \%$ exclusion of non-AMI patients using this method. Haastrup et al. ${ }^{(96)}$, used the same approach of serial measurements and reported an increase of factor 3 to 4 in the probability of detecting an AMI. In both studies, patients were admitted to the Coronary Care Unit within $6 \mathrm{~h}$ after onset of symptoms. However, should patients arrive after $6 \mathrm{~h}$ after onset of symptoms, this method would not be valid anymore as H-FABP plasma values will decrease from peak values at 4 to $6 \mathrm{~h}$ to normal plasma levels at 12 to $24 \mathrm{~h}$.

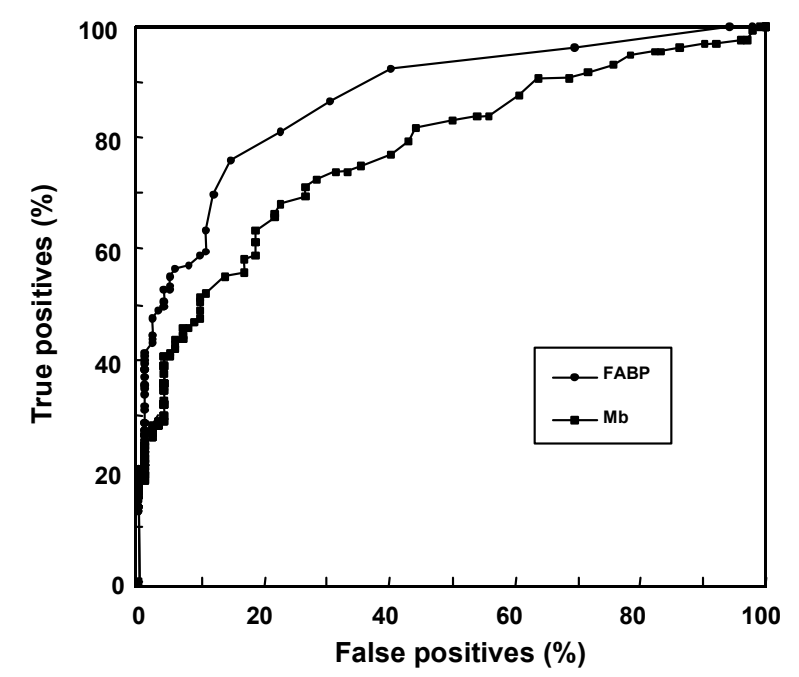

Figure 2.3 Receiver operating (ROC) curves for detection of acute myocardial infarction (AMI) in 238 patients with chest pain suggestive of $\mathrm{AMl}$ and admitted to hospital within $6 \mathrm{H}$ after onset of symptoms, comparing the concentrations of H-FABP $(\bullet)$ and myoglobin $(\mathrm{Mb})(\circ) .{ }^{(90)}$

On-line continuous monitoring of plasma FABP would require the sampling of blood constituents via a microdialysis probe or via continuous ultrafiltration of venous blood (at a rate of $0.1-1 \mu \mathrm{L} / \mathrm{min}$ ), both of which have been described previously. ${ }^{(97)}$ Furthermore, an immunodisplacement assay has been developed for an on-line biosensor for $\mathrm{H}$ $\mathrm{FABP}^{(98)}$ and is expected to be useful for the on-line monitoring of patients during open heart surgery or with unstable angina. This approach would have the advantage of a rapid determination of changes in plasma FABP concentration, independent of its reference concentration, and therefore a more early diagnosis or exclusion of AMI. ${ }^{(98)}$

\section{Minor myocardial injury: congestive heart failure and unstable angina pectoris}

Although acute myocardial infarctions account for most myocardial injuries, elevated plasma concentrations of cTnT have also been shown in a marked proportion of patients with congestive heart failure (CHF), indicating that progressive deterioration of ventricular function in CHF patients is associated with ongoing minor myocardial injury and worse prognosis. ${ }^{(99)}$ In addition, in patients with idiopathic dilated cardiomyopathy $^{(100)}$ and with unstable angina pectoris (UAP) ${ }^{(101-103)}$, elevated levels of cTnT or cTnI indicate minor necrosis and increased risk.

Preliminary reports for CHF patient groups showed that serum H-FABP concentrations were higher with more severe heart failure, and significantly correlated with serum TnT. In addition, the subgroup of patients with the highest serum H-FABP levels showed the highest incidence of subsequent cardiac events. ${ }^{(104,105)}$ Recently, these observations have been confirmed for other patient groups and indicate that H-FABP is a 
very sensitive marker of minor myocardial injury in patients with congestive heart failure $^{(106,107)}$ One study showed that in a group of 58 patients with CHF (NYHA class III or IV), plasma H-FABP level was elevated $(>6 \mu \mathrm{g} / \mathrm{L})$ in 47 patients, while cTnT was elevated $(>0.02 \mu \mathrm{g} / \mathrm{L})$ in only 31 patients ${ }^{(107)}$ (see Chapter 6). Increased specificity of $\mathrm{H}-$ FABP, compared to cTnT, was indicated by the fact that, when plasma H-FABP was $<6$ $\mu \mathrm{g} / \mathrm{L}$, the negative predictive value for a recurrent event within 90 days was $81 \%$, while cTnT $<0.02 \mu \mathrm{g} / \mathrm{L}$ showed a negative predictive value of $57 \%$. ${ }^{(53)}$ This difference most likely is explained by insufficient sensitivity of the cTnT assay. Although for cTnT a cutoff value of $0.1 \mu \mathrm{g} / \mathrm{L}$ for indication of myocardial injury is commonly used, 0.05 and 0.02 $\mu \mathrm{g} / \mathrm{L}$ are now being evaluated as proper cut-off now that more sensitive immunoassays are being developed.

In patients with UAP, often including minor myocardial injury, H-FABP allows an early and sensitive assessment of injury as demonstrated by Katrukha et al. ${ }^{(57)}$ Patients $(\mathrm{n}=31)$ with UAP showed elevated $(>0.2 \mu \mathrm{g} / \mathrm{l}) \mathrm{cTnI}$ plasma levels in $13 \%$ and elevated $\mathrm{H}-$ FABP plasma levels $(>6 \mu \mathrm{g} / \mathrm{L})$ in $54 \%$ of the admission samples, whereas at $6 \mathrm{~h}$ after admission, cTnI was elevated in $58 \%$ and H-FABP in $52 \%$ of the samples. Smith et al. ${ }^{(103)}$ reported 4 out of 18 UAP patients showed elevated plasma H-FABP levels in samples taken 2-4 h after onset of symptoms (chest pain). These preliminary data suggest that H-FABP is a sensitive marker for minor myocardial injury in patients with UAP, with similar sensitivity as CTnI, but at an earlier point after admission.

The putative application of H-FABP as marker for the detection of myocardial injury is illustrated for four selected patients who each were clinically diagnosed as having UAP, but whose plasma release curves of H-FABP showed a characteristic rise and fall and reached values above the clinical cut-off value of $6 \mu \mathrm{g} / \mathrm{L}$ (Fig. 2.4). ${ }^{(18)}$ In each of these cases the plasma myoglobin concentration followed that of H-FABP but did not show a clear curve and/or did not reach the clinical cut-off value of $60 \mu \mathrm{g} / \mathrm{L}$ (Fig. 2.4).

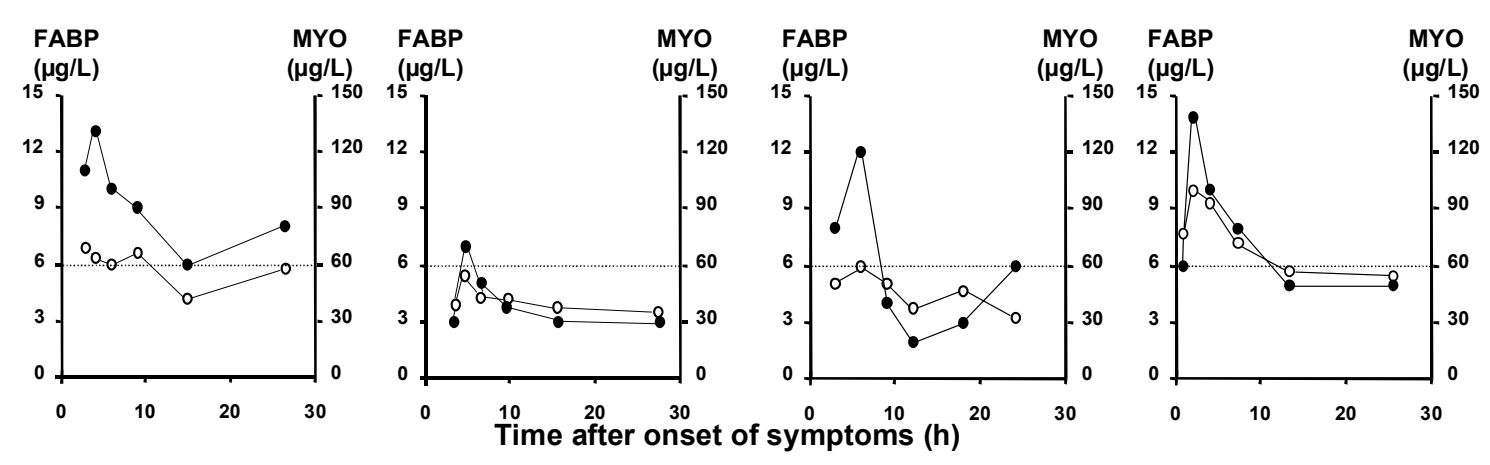

Figure 2.4 Examples of plasma release curves of H-FABP and myoglobin in four individual patients clinically diagnosed as having unstable angina pectoris (UAP). In these patients, plasma $\mathrm{H}$-FABP $(\bullet)$ and myoglobin $(\mathrm{Mb})(\mathrm{O})$ were elevated above their respective reference value (dashed line; $6 \mu \mathrm{g} / \mathrm{L}$ for H-FABP and $60 \mu \mathrm{g} / \mathrm{L}$ for myoglobin) and show a typical "rise and fall" pattern, suggesting the occurrence of minor myocardial injury. Data obtained from the EUROCARDI multicenter trial. ${ }^{(90)}$

Infarct size, reperfusion and coronary bypass grafting

Several studies show that the cumulative release of CK, LDH, myoglobin and H-FABP can be used to estimate myocardial infarct size, taking into account the specific clearance rates from plasma. ${ }^{(38,55,108,109)}$ When evaluating early thrombolytic therapy in patients 
with AMI, quantification of infarct size can reliably be performed but as the usual enzymatic markers appear relatively late in blood, data become available rather late to have an influence on acute care. ${ }^{(110,111)}$ Therefore, it is of interest that the more rapidly released markers H-FABP and myoglobin can also be applied for infarct quantification. $^{(38,108)}$ Because H-FABP and myoglobin are cleared via the kidneys, renal insufficiency could hamper the utility of both proteins. However, to correct for the effect of renal insufficiency, individually estimated clearance rates can successfully be applied for infarct size estimation as suggested by De Groot et al. ${ }^{(55)}$. As a result, myocardial infarct size can also be measured from plasma H-FABP in patients with renal failure. ${ }^{(11)}$

Detection of successful coronary reperfusion in patients with AMI, using $\mathrm{H}-$ FABP, has been reported by three independent groups of investigators. ${ }^{(112-114)}$ Following successful reperfusion both plasma H-FABP and myoglobin were found to rise sharply, whereas in patients with failed reperfusion these markers rise at a slower rate. H-FABP and myoglobin perform equally well as non-invasive markers to discriminate between reperfused and non-reperfused patients, but generally relatively low sensitivities and specificities (approximately 70\%) were found. Normalization to infarct size improved these to approximately $80 \%$, indicating their suitability in retrospective studies with known infarct size. ${ }^{(112,115)}$

Several studies show that H-FABP also can be useful for early detection of postoperative myocardial tissue loss in patients undergoing coronary bypass surgery. ${ }^{(88,116-119)}$ Myocardial injury in such patients may be caused by global ischemia/reperfusion ${ }^{(120)}$ injury and, in addition, by postoperative myocardial infarction. Fransen et al. ${ }^{(116)}$ reported that in patients developing a postoperative myocardial infarction, a second increase in plasma markers was observed in which H-FABP increased already $4 \mathrm{~h}$ after reperfusion, while CK and myoglobin increased not until $8 \mathrm{~h}$ after reperfusion, allowing for an earlier indication of postoperative myocardial infarction, and also permitting the earlier transport of patients without infarction from the intensive care unit to the ward.

\subsubsection{Skeletal muscle injury}

H-FABP is mainly expressed in the heart, but to a lesser extent also in skeletal muscle (Table 2.3). Monitoring myocardial injury may be hampered when patients suffered skeletal muscle injury either due to cardioversion, multiorgan failure, postoperative states, or vigorous exercise. This monitoring problem can be overcome by using the plasma ratio of myoglobin over H-FABP concentrations. This ratio in plasma reflects the ratio of the contents of both proteins in the affected tissue, as the latter differs between heart muscle (myoglobin/H-FABP ratio 2 to 5) and skeletal muscles (myoglobin/H-FABP ratio 20 to 70 , depending on type of muscle. ${ }^{(73,88,119)}$ ). In patients with AMI, it was found that the plasma myoglobin/H-FABP ratio is approximately 5 during the entire period of elevated plasma levels, while for patients with aortic surgery (causing no-flow ischemia of the lower extremities), the plasma myoglobin/H-FABP ratio was $45 .{ }^{(73,119)}$ When patients are defibrillated shortly after AMI, intercostal pectoralis muscles are likely to be injured, and an increase in plasma myoglobin/H-FABP ratio was seen rising from 8 to 60 during $24 \mathrm{~h}$ after AMI. ${ }^{(73)}$ In cases where a second increase in plasma concentrations of marker proteins occurs, this ratio can be helpful to discriminate a recurrent infarction (ratio remains at 2 to 5) from additional skeletal muscle injury (ratio rises to 20-70).

In the case of vigorous exercise, skeletal muscle damage occurs which results in a temporary loss of muscle function and coordination. ${ }^{(121)}$ Normally, increased blood levels 
of CK and myoglobin are used to diagnose exercise induced muscle damage ${ }^{(121-123)}$, but Sorichter et al. ${ }^{(56)}$ showed that after 20 min of downhill running (eccentric muscle contractions), plasma H-FABP increases after physical exercise by healthy subjects, and that its pattern of release into and clearance from the blood is similar to that of myoglobin. For both H-FABP and myoglobin, a significant increase was reached earlier (30 min) than for CK (2 h), indicating the usefulness of the former for the early detection of muscle injury. cTnI was not detectable in plasma from the investigated athletes, indicating that the source of muscle protein release after downhill running is damaged skeletal muscle rather than heart muscle, which was confirmed by a plasma myoglobin/H-FABP ratio of $15{ }^{(56)}$ Also in a group of junior rowers, plasma levels of $\mathrm{H}-$ FABP and of CK were evaluated during 5 weeks of training ${ }^{(124)}$ and showed that acute exercise induced a larger relative increase in plasma H-FABP (70 to $362 \%)$ than in CK (24 to 156\%). Taken together, these data indicate that simultaneous measurement of $\mathrm{H}$ FABP and myoglobin in plasma could be helpful for the early diagnosis of skeletal muscle damage, as the combination of these markers can give trainers and athletes early and specific information about the exercised skeletal muscles in training sessions and after competition. This information will help avoid additional skeletal muscle damage or overtraining and could allow better control of specific training sessions.

\subsubsection{Liver injury}

Release of cytoplasmic proteins from damaged hepatocytes into the vascular system can be caused by e.g. acetaminophen (paracetamol) intoxication, ischemia and reperfusion injury, liver congestion, shock, trauma or rejection after transplantation. The hepatocytes are in close contact with the vasculature, as they are separated by a single endothelial layer with large clefts as mentioned before (see section 2.5.1). Biochemical plasma markers of acute hepatocellular injury, including alanine aminotransferase (ALT), and aspartate aminotransferase, are commonly used to investigate the presence, and monitor the progress, of liver disease. ${ }^{(125)}$ The currently used markers, however, lack sensitivity, and, with the exception of ALT, adequate specificity for liver disease. Although ALT can be measured very quickly and cost-effectively on a routine clinical analyzer, the fact remains that the plasma concentration of this relatively large protein $(96 \mathrm{kD})$ is rather late to increase above the upper reference value after cell damage. Thus, more specific and sensitive markers of liver injury in general are needed for patient monitoring. ${ }^{(126)}$

Recently, alpha glutathione S-transferase ( $\alpha$-GST) has been introduced as the most sensitive and specific marker of hepatocellular damage currently available commercially. This cytoplasmic $26 \mathrm{kD}$ protein, present in liver, kidney and intestine, is released rapidly from damaged hepatocytes, and has a short in vivo plasma half-life. ${ }^{(127-}$ ${ }^{130)}$ In a randomized trial to look at the clinical benefit, it was shown that by using $\alpha$-GST for indication of hepatocellular injury due to rejection after liver transplantation, mortality and morbidity decreased due to the more rapid augmentation of immunosuppressive drugs. ${ }^{(128)}$

In search of even smaller and more specific cytoplasmic proteins of liver injury, livertype FABP (L-FABP) $)^{(1,15,131,132)}$ shows to be a promising new marker. Pelsers et al. ${ }^{(43)}$ investigated L-FABP release following hepatocellular injury due to rejection in a group of liver transplant recipients who had episodes of acute hepatocellular rejection during their post-transplantation stay in the hospital. Such patients are intensely monitored to control their periods of rejection. ${ }^{(133-135)}$ Acute rejection as final diagnosis is currently 
based on liver biopsy data. ${ }^{(136)}$ Clinical symptoms like fever, malaise and jaundice as well as liver function tests indicate whether a biopsy has to be taken. ${ }^{(137)}$ The forementioned study showed that L-FABP rises significantly in all rejection periods and can be detected in plasma earlier than $\alpha$-GST and ALT (Chapter 10, Fig. 10.2 and 10.3). ${ }^{(43)}$ L-FABP is also earlier when the day of treatment is taken as reference. Due to the abundant content of L-FABP in liver tissue, the relative elevation of serum values after liver injury is higher than those of $\alpha$-GST and of ALT, making L-FABP a more sensitive marker. ${ }^{(43)}$ This sensitivity most likely can even be enhanced as more frequent bloodsampling allows better monitoring of the rise of a plasma marker. Although only a small group of patients was tested, this study shows that L-FABP is a promising new biochemical marker for the early detection of hepatocellular injury. ${ }^{(43)}$

\subsubsection{Kidney injury}

Maatman et al. ${ }^{(72,74)}$ discovered already in 1992 the presence of two types of FABP in the kidney, which later turned out to be H-FABP, located in the distal tubular cells, and LFABP which is located in the proximal tubular cells. Remarkably, however, the application of FABP as marker for kidney injury due to ischemia or toxic heavy metals has only recently been investigated. ${ }^{(138-143)}$

\section{Nephrotoxicity}

Environmental or occupational exposure to toxic metals such as mercury $(\mathrm{Hg})$, lead $(\mathrm{Pb})$, or cadmium $(\mathrm{Cd})$ is well known to lead to renal diseases like acute renal failure. ${ }^{(144)}$ Although the exact mechanisms of metal nephrotoxicity remain unclear, histological characteristic features are lesions that tend to predominate in specific regions of the nephron within specific cells ${ }^{(145)}$, while functional alterations are characterized by changes in renal plasma flow, glomular filtration rate, and proximal or distal tubular damage. ${ }^{(146)}$ Also gentamicin and cyclosporin are known to induce dose dependently renal injury. The assessment of biomarkers to detect nephrotoxicity has been studied before, but sensitivity and specificity of urinary- and serum profiles of these markers still need to be improved. ${ }^{(147-149)}$

Urinary H-FABP levels were evaluated in a rat model, showing that administration of mercuric chloride, cyclosporin and gentamycin all induced renal damage. ${ }^{(142)}$ Especially in gentamicin treated rats, urinary H-FABP levels increased markedly, indicating distal tubular injury and expressing the sensitivity of H-FABP compared to currently used markers (see Chapter 8).

\section{Kidney transplants}

Renal transplantation is a recognized treatment for end-stage renal failure. ${ }^{(150)}$ The increasing shortfall in the availability of donor organs for transplantation has led to a renewed interest in the non-heart-beating donor (NHBD) as a potential source of transplantable kidneys. It has been estimated that the UK donor pool could be increased by 20 to $45 \%$ by the universal inclusion of NHBD derived kidneys. ${ }^{(151)}$ However, a major problem with the use of such kidneys is the inevitable tissue damage sustained from periods of warm ischemia. This ischemic tissue injury associates the use of NHBD kidneys with two adverse conditions, namely primary nonfunction and delayed graft function. Thus, the success of NHBD renal transplants depends on the efficacy of pretransplant organ preservation and viability assessment to detect damaged kidneys that will never work. Machine preservation using continuous hypothermic pulsatile perfusion 
has great advantages in preventing warm ischemia induced tissue injury and has been adopted in NHBD kidney screening initiatives. ${ }^{(152)}$ Perfusion characteristics (flow, pressure, resistance, temperature, weight gain) with biochemical marker analysis of kidney effluents are used to assess viability. Although a number of such parameters have been investigated with mixed success, the quantification of the total enzyme activity of glutathione-S-transferase (tGST) ${ }^{(153)}$ is currently regarded as the most promising. However, there is still no reliable biochemical marker to predict long-term viability.

To evaluate the use of FABP types, Kievit et al. ${ }^{(153)}$ showed, that after aortic clamping in rats, H-FABP plasma levels were elevated significantly earlier than those of the currently used markers tGST and lactate dehydrogenase. ${ }^{(153)}$ L-FABP showed no significant changes. Continuing these finding in a human setting, the potential of H-FABP as biochemical marker, was compared with alanine aminopeptidase (Ala-AP) ${ }^{(154)}$ and tGST, to indicate renal tissue injury in machine perfusion pretransplant and to predict long-term renal function. ${ }^{(138-141)}$ tGST, Ala-AP and H-FABP plasma concentrations showed similar increases in NHBD kidney perfusates over a $4 \mathrm{~h}$ machine perfusion period. The activities of each marker were similarly raised (at corresponding perfusion time points) in discarded versus transplanted kidneys, with H-FABP having the tendency to be the most sensitive marker. ${ }^{(138-141)}$ Based on these findings, the conclusion was reached that next to donor age, donor medical history, macroscopic appearance, warm ischemic time and ex vivo perfusion, biomarkers like H-FABP represent useful pre-transplant indicators of immediate kidney viability and short term kidney function. ${ }^{(139)}$ Although the protein plasma markers did not predict the efficacy of renal function in the long term, the use for short-term screening of kidney function does lead to a survival rate of NHBD kidneys which is sufficient to serve as an important source to match the increasing waiting lists.

\subsubsection{Intestinal injury}

For the early detection of intestinal injury due to small bowel ischemia, inflammation or rejection, no plasma protein is routinely analyzed. Several studies have investigated the use of biochemical markers like hexoaminidase and lactate dehydrogenase ${ }^{(59)}$ or physiological markers like mucosal $\mathrm{pH}^{(155)}$, but these were non-conclusive. I-FABP occurs in the enterocytes of small intestine and constitutes $2 \%$ of enterocyte protein. ${ }^{(156,157)}$ Interestingly, intestinal cells also express L-FABP, which occurs in liver and additionally in kidney. ${ }^{(74)}$ When intestinal ischemia is limited to a period of less than $2 \mathrm{~h}$, only the villi are affected while the crypt cells remain intact, and there is a rapid recovery of function. ${ }^{(158)}$ Because I-FABP and L-FABP are mainly expressed in the villi and not in the crypt ${ }^{(45,156,157)}$, both proteins may be early and sensitive plasma markers of intestinal ischemia. Previous studies by Marks, Gollin and Lieberman describe the use of I-FABP for the detection of rat intestinal injury after acute ischemic diseases ${ }^{(59)}$, rejection ${ }^{(60,159)}$ and necrotic enterocolitis ${ }^{(44)}$, but in patients, different results were reported. ${ }^{(45,160-166)}$ Lieberman et al. ${ }^{(45,165)}$ showed elevated serum I-FABP concentrations, ranging from $1.9 \mu \mathrm{g} / \mathrm{L}$ to $50 \mu \mathrm{g} / \mathrm{L}$, in patients with necrotic enterocolitis, intestinal ischemia and systemic inflammatory response syndrome. In cardiopulmonary bypass, gastrointestinal perfusion was altered and elevated I-FABP urinary levels in high risk patients indicated intestinal ischemia. ${ }^{(160)}$ This was also shown by Kanda et al. ${ }^{(163,164)}$ in serum of patients with intestinal ischemia and mesenteric infarction, but Kaufman et al. ${ }^{(166)}$ presented lack of utility of I-FABP in predicting intestinal allograft rejection.

Recently, Guthmann et al. ${ }^{(46)}$ described the use of both I-and L-FABP as diagnostic markers for necrotic enterocolitis in preterm infants and concluded that L-FABP is a 
promising sensitive marker for stage I, while I-FABP appears to be a specific parameter for the early detection of intestinal injury leading to severe stage III. ${ }^{(46)}$

These data were confirmed by Pelsers et al. ${ }^{(47)}$, who investigated tissue distribution and contents of both I-FABP and L-FABP in human intestine along the duodenal to colonal axis in surgery and autopsy samples, and the potential of these proteins as plasma marker for the detection of intestinal injury in patients with intestinal and/or hepatic disease (see Chapter 11). The L-FABP tissue contents in the small intestine were markedly higher than those of I-FABP (Chapter 11, Figure 11.2). For L-FABP, comparable data were published by Sakai et al. ${ }^{(167)}$ Elevated plasma levels of both IFABP and L-FABP were found in patients suffering from intestinal diseases, while only L-FABP was increased in cases of purely hepatocellular injury (Chapter 11, Figure 11.3). ${ }^{(47)}$ As a result, besides I-FABP, also L-FABP appears a useful plasma marker for the detection of intestinal injury, especially in patients undergoing intestinal surgery. Although these proteins show a distinct pattern of tissue distribution, their ratio in plasma after intestinal injury was not significantly different and, therefore, did not allow localization of necrosis. H-FABP, which is expressed in smooth muscle cells ${ }^{(73)}$, was measured to investigate whether intestinal autopsy samples are comparable in their amount of muscle cells to reveal no significant differences in the complete small intestinal tract (Chapter 11, Figure 11.2). ${ }^{(47)}$

\subsubsection{Brain injury}

The most recent development for using FABP as tissue injury marker is for brain injury. Research in the field of brain-specific proteins as biochemical plasma markers for neurological disorders or brain injury is expanding. Protein S100B, neuron-specific enolase, myelin basic protein and glial fibrillary acidic protein are presently being evaluated as marker proteins in cerebrospinal fluid and/or blood for detection of brain injury in neurological patients ${ }^{(168-170)}$, patients with cerebrovascular accidents ${ }^{(171)}$, traumatic brain injury ${ }^{(172)}$, stroke ${ }^{(173,174)}$, or tumor cerebri ${ }^{(175)}$ and dementia ${ }^{(176)}$, eventually even to locate the site of injury (neuron, glia or myelin). However, conflicting results on elevated S100B serum concentrations after cardiac injury ${ }^{(177-179)}$ indicate that the specificity of this protein is limited.

Brain-type FABP (B-FABP) and H-FABP are new potential markers for the detection of brain injury. B-FABP was first identified in the brain of rodents showing a variable tissue expression during development. ${ }^{(75,180-183)}$ Quantitative data on tissue content in segments of the human brain as well as the potential of both FABPs as plasma marker for the detection of brain injury in patients were recently studied ${ }^{(48)}$ (see Chapter 12). Frontal-, temporal-, occipital lobe, striatum, pons and cerebellum showed 10 fold higher tissue contents of H-FABP compared to B-FABP (Table 2.3). Unlike B-FABP, HFABP is detected in the neurons of the gray matter (neuronal cell bodies) and constitutes $0.01 \%$ of total brain cytosolic protein. ${ }^{(75,184)}$

In healthy individuals, with the available immunoassay (detection limit $5 \mu \mathrm{g} / \mathrm{L}$ ), no BFABP could be detected in plasma or serum. ${ }^{(48)}$ In patients with mild traumatic brain injury $(n=130)$, serum levels of B-FABP were elevated in $68 \%$ and of H-FABP in $70 \%$ of the patients, compared to elevated concentrations of S100B found in $45 \%$ and of NSE in $51 \%$ of the patients. In serum samples $(n=234)$ of patients treated with electroconvulsive therapy $(\mathrm{n}=14)$, B-FABP was elevated in $6 \%$ of the samples, while H-FABP was above its reference value of $6 \mu \mathrm{g} / \mathrm{L}$ in $17 \%$ of the samples, and S100B was above its reference level of $0.3 \mu \mathrm{g} / \mathrm{L}$ in $0.4 \%$ of the samples. These patient studies indicate that B-FABP and 
H-FABP are more sensitive markers for brain injury than the currently used markers S100B and NSE. ${ }^{(48)}$ Guilaume et al. ${ }^{(184,185)}$ recently proposed H-FABP and B-FABP as markers for brain injury in stroke and Creutzfeld-Jacob, but unfortunately only nonquantitative data on H-FABP were presented.

\subsection{Conclusion and perspectives}

Biochemical plasma markers have become important parameters in the management of patients with tissue injury due to ischemia/reperfusion, rejection or trauma. Small cytoplasmic proteins are preferred for this purpose as they rapidly diffuse from damaged cells into the circulation. Certainly in the field of myocardial injury, these biochemical markers have proven important tools for the diagnosis of patients with suspected acute myocardial infarction especially in those cases where ECG changes are equivocal or absent, and therefore are included in criteria for the diagnosis of acute coronary syndromes, next to clinical symptoms and ECG pattern. ${ }^{(82,186,187)}$ In the last decades, these biochemical markers have gained increasing attention for several reasons. First, the introduction of new therapeutic strategies has called for earlier and more sensitive markers for appropriate diagnosis of patients, especially in case of acute coronary syndromes or cerebrovascular accidents, so as to begin the proper therapy as early as possible. ${ }^{(188,189)}$ Second, several new plasma markers have been introduced and some were found not only to allow for the assessment of the disease, but also to be of prognostic value. ${ }^{(88)}$ FABP is a novel biochemical marker with a relatively high tissue content and a low normal plasma value which result in specific release characteristics to make it the preferred plasma marker for early diagnosis of tissue injury.

H-FABP has proven not only to be an excellent marker for cardiac injury in acute coronary syndromes ${ }^{(17,18,39,94)}$, but also sensitive enough for detecting minor myocardial injury in heart failure. ${ }^{(57,100,106,190)}$ Importantly, all clinical studies with patients suspected of having an acute myocardial infarction and evaluating both H-FABP and myoglobin, have revealed a superior performance of H-FABP over myoglobin for the early detection of acute myocardial infarction. Limitations of the use of H-FABP as a diagnostic plasma marker for myocardial injury are the fact that (i) it is not cardiospecific, (ii) the diagnostic window is relatively small, extending to only 24 to $30 \mathrm{~h}$ after onset of chestpain, and (iii) its elimination from plasma by renal clearance can cause falsely high values in case of kidney malfunction. However, despite these possible drawbacks, H-FABP has been reported still as the most sensitive plasma marker for myocardial injury, and has the advantage to rapidly detect a re-infarction and the ability to be used as a marker for infarct size quantification by using individually estimated renal clearance rates.

Because H-FABP also is expressed in distal tubular cells, it can be used as biomarker for detection of ischemic injury in kidney perfusates of non-heart beating (NHBD) donors. Several reports already indicate H-FABP to be a better marker for shortterm transplant viability assessment than the currently used marker GST. Both H-FABP and GST seem not to be useful to predict long-term renal function post-transplant of machine-perfused NHBD kidneys. ${ }^{(140-143)}$ Interestingly, H-FABP and GST are good markers for renal toxicity. ${ }^{(142)}$ More recently, H-FABP also appears to be a marker for brain injury as it is expressed in the gray matter of the brain. Together with the newly developed marker of brain injury, B-FABP, promising new data about the detection of injury in patients with mild brain trauma or electroconvulsive therapy have been reported. ${ }^{(48)}$ In view of the expression of H-FABP in several tissues, a multi-marker 
approach may be recommended to differentiate tissue injury of either heart, kidney or brain.

L-FABP has only recently been investigated as injury marker, and shows promising results as new marker for rejection induced liver injury ${ }^{(43)}$, and as marker for intestinal injury. ${ }^{(47)}$ The relatively high intestinal content of L-FABP, when compared to I-FABP, makes L-FABP a more sensitive plasma marker for intestinal injury. Again, a multimarker approach would have to be used to differentiate between liver- and intestinal injury. Intestinal injury can specifically be detected by plasma I-FABP, as this FABP type only occurs in intestinal enterocytes. However, its tissue expression is relatively low ${ }^{(47)}$, so that more sensitive immunoassays should be developed to fully exploit the potential of this marker, and also to establish a proper reference interval and to investigate biological variations in plasma levels of normal healthy controls.

This comment also applies to the specific marker of brain injury, B-FABP. The presently available immunoassay for B-FABP has a high detection limit that did not allow for the detection of B-FABP in plasma of healthy individuals. ${ }^{(48)}$

Specific FABP types also occur in ileal enterocytes (ileal lipid binding protein, ILBP) ${ }^{(191)}$, peripheral nervous system (myelin lipid binding protein, M-LBP) ${ }^{(192)}$, testis (TFABP $)^{(193)}$, and epidermal cells $(\mathrm{E}-\mathrm{FABP}) .{ }^{(194)}$ The use of these proteins as plasma markers for tissue injury has, however, not yet been explored.

In spite of the fact that not all FABPs are tissue specific, this family of small cytoplasmic proteins is gaining more and more interest as early and sensitive plasma markers of tissue injury. A rapid test format to be applied to all FABP types by simply exchanging specific monoclonal antibodies, would make the FABPs important plasma parameters, especially in the field of point-of care testing, for detection of cardiac, kidney, liver, intestinal and brain injury, alone or in combination with other markers, so as to diagnose and treat patients as early as possible.

\subsection{References}

1. Glatz JFC, Van der Vusse GJ. Cellular fatty acid-binding proteins. Their function and physiological significance. Prog Lipid Res 1996;35:243-82.

2. Storch J, Thumser EA. The fatty acid transport function of fatty acid-binding proteins. Biochim Biophys Acta 2000;1486:28-44.

3. Banaszak L, Winter N, Xu Z, Bernlohr DA, Cowan S, et al. Lipid binding proteins: a family of fatty acid and retinoid transport proteins. Adv Protein Chem 1994;45:89-151.

4. Schaap FG, Van der Vusse GJ, Glatz JFC. Evolution of the family of intracellular lipid binding proteins in vertebrates. Moll Cell Biochem 2002;239:69-77.

5. Young AC, Scapin G, Kromminga A, Patel SB, Veerkamp JH, et al. Structural studies on human muscle fatty acid-binding protein at $1.4 \AA$ resolution: Binding interaction with three C18 fatty acids. Structure 1994;2:523-34.

6. Schaap FG, Binas B, Danneberg H, van der Vusse GJ, Glatz JF. Impaired long-chain fatty acid utilization by cardiac myocytes isolated from mice lacking the heart-type fatty acid binding protein gene. Circ Res 1999;85:329-37.

7. Wolfrum C, Borrmann CM, Borchers T, Spener F. Fatty acids and hypolipidemic drugs regulate peroxisome proliferator-activated receptors alpha - and gamma-mediated gene expression via liver fatty acid binding protein: a signaling path to the nucleus. Proc Natl Acad Sci USA 2001;98:2323-8.

8. Glatz JFC, Storch J. Unraveling the significance of cellular fatty acid-binding proteins. Curr Opin Lipidol 2001;12:267-74. 
9. Sambandam N, Lopaschuk GD. AMP-activated protein kinase (AMPK) control of fatty acid and glucose metabolism in the ischemic heart. Prog Lipid Res 2003;42:238-56.

10. Van Breda E, Keizer HA, Vork MM, Surtel DA, de Jong YF, et al. Modulation of fatty acidbinding protein content of rat heart and skeletal muscle by endurance training and testosterone treatment. Eur J Physiol 1992;421:274-9.

11. Glatz JFC, Van Breda E, Keizer HA, de Jong YF, Lakey JR, et al. Rat heart fatty acidbinding protein content is increased in experimental diabetes. Biochem Biophys Res Commun 1994;199:639-46.

12. Pelsers MMAL, Lutgerink JT, Nieuwenhoven FA, Tandon NN, van der Vusse GJ, et al. A sensitive immunoassay for rat fatty acid translocase (CD36) using phage antibodies selected on cell transfectants: abundant presence of fatty acid translocase/CD36 in cardiac and red skeletal muscle and up-regulation in diabetes. Biochem $J$ 1999;337:407-14.

13. Kragten JA, Van Nieuwenhoven FA, Van Dieijen-Visser MP, Theunissen PH, Hermens WT, et al. Distribution of myoglobin and fatty acid-binding protein in human cardiac autopsies. Clin Chem 1996;42:337-8.

14. Vork MM, Trigault N, Snoeckx LHEK, Glatz JFC, Van der Vusse GJ. Heterogenous distribution of fatty acid-binding protein in the hearts of Wistar Kyoto and spontaneously hypertensive rats. J Mol Cell Cardiol 1992;24:317-21.

15. Bass NM, Barker ME, Manning JA, Jones AL, Ockner RJ. Acinar heterogeneity of fatty acidbinding protein in the livers of male, female and clofibrate treated rats. Hepatology 1989;9:12-21.

16. Glatz JFC, Van Bilsen M, Paulussen RJA, Veerkamp J, Van der Vusse GJ, et al. Release of fatty acid-binding protein from isolated rat heart subjected to ischemia and reperfusion or the calcium paradox. Biochim Biophys Acta 1988;961:148-52.

17. Nakata T, Hashimoto A, Hase M, Tsuchihashi K, Shimamoto K. Human heart-type fatty acid-binding protein as an early diagnostic and prognostic marker in acute coronary syndrome. Cardiology 2003;99:96-104.

18. Glatz JFC, Van der Voort D, Hermens WT. Fatty acid-binding protein as the earliest available plasma marker of acute myocardial injury. J Clin Lig Ass 2002;25:167-77.

19. Roos W, Eymann E, Symannek M, Duppenthaler J, Wodzig KWH, et al. Monoclonal antibodies to human heart fatty acid-binding protein. J Immunol Methods 1995;183:149-153.

20. Okhura Y, Asayama K, Ishii H, Nishimura S, Sunahara N, et al. Development of a sandwich enzyme-linked immunosorbent assay for the determination of human heart-type fatty acidbinding protein in plasma and urine by using two different monoclonal antibodies specific tot human heart fatty acid-binding protein. J Immunol Methods 1995;178:99-111.

21. Wodzig KWH, Pelsers MMAL, Van der Vusse GJ, Roos W, Glatz JFC. One-step enzyme linked immunosorbent assay (ELISA) for plasma fatty acid-binding protein. Ann Clin Biochem 1997;34:263-8.

22. Knowlton AA, Burrier RE, Brecher P. Rabbit heart-protein. Isolation, characterisation, and application of a monoclonal antibody. Circ Res 1989;65:981-8.

23. Watanabe K, Wakabayashi H, Veerkamp JH, Ono T, Suzuki T. Immunohistochemical distribution of heart-type fatty acid-binding protein immunoreactivity in normal human tissue and after an acute myocardial infarction. J Pathol 1993;170:59-65.

24. Jagschies G, Reers M, Unterberg C, Spener F. Bovine fatty acid-binding proteins. Isolation and characterisation of two cardiac fatty acid-binding proteins that are distinct from corresponding hepatic proteins. Eur J Biochem 1985;152:537-45.

25. Zschiesche W, Kleine A, Spitzer E, Veerkamp JH, Glatz JF. Histochemical localization of heart-type fatty acid-binding protein in human and murine tissues. Histochem Cell Biol 1995;103:147-56.

26. Epstein LF, Bass NM, Iwahara S, Wilton DC, Muller-Eberhard U. Immunological identity of rat liver cytosolic heme-binding protein with purified and recombinant liver fatty acid binding protein by western blots of two-dimensional gels. Biochem Biophys Res Commun 1994;204:163-8. 
27. Pelsers MM, Chapelle JP, Knapen M, Vermeer C, Muijtjens AMM, et al. Influence of age, sex and day-to-day and within-day biological variation on plasma concentrations of fatty acid-binding protein and myoglobin in healthy subjects. Clin Chem 1999;45:441-3.

28. Vork MM, Glatz JFC, Surtel DA, Knubben HJ, Van der Vusse GJ. A sandwich enzymelinked immunosorbent assay for the determination of rat heart fatty acid-binding protein using the streptavidin-biotin system. Application to tissue and effluent samples from normoxic rat heart perfusion. Biochim Biophys Acta 1991;1075:199-205.

29. Crisman TS, Claffey KP, Saouaf R, Hanspal J, Brecher P. Measurement of rat heart fatty acid-binding protein by ELISA. Tissue distribution, developmental changes and sub-cellular distribution. J Mol Cell Cardiol 1987;19:423-31.

30. Das DK, Barua PK, Jones RM. Release of fatty acid-binding protein from ischemicreperfused rat heart and its prevention by mepacrine. Biochim Biophys Acta 1991;1073:394401.

31. Knowlton AA, Apstein CS, Saouf R, Brecher P. Leakage of heart fatty acid-binding protein with ischemia and reperfusion in the rat. J Mol Cell Cardiol 1989;21:577-83.

32. Paulussen RJ, van Moerkerk HT, Veerkamp JH. Immunochemical quantification of fatty acid-binding proteins. Tissue distribution of liver and heart FABP types in human and porcine tissues. Int J Biochem 1990;22:393-8.

33. Börchers T, Unterberg C, Rudel H, Robenek H, Spener F. Subcellular distribution of cardiac fatty acid-binding protein in bovine heart muscle and quantification with an enzyme-linked immunosorbent assay. Biochim Biophys Acta 1989;1002:54-61.

34. Guglielmo CG, Haunerland NH, Hochachka PW, Williams TD. Seasonal dynamics of flight muscle fatty acid binding protein and catabolic enzymes in a migratory shorebird. Am J Physiol Regul Integr Comp Physiol 2002;282:R1405-13.

35. Londraville RL, Sidell BD. Purification and characterization of fatty acid-binding protein from aerobic muscle of the Antarctic icefish Chaenocephalus aceratus. $J$ Exp Zool 1995;273:190-203.

36. Haunerland NH, Andolfatto P, Chisholm JM, Wang Z, Chen X. Fatty acid-binding protein in locust flight muscle. Developmental changes of expression, concentration and intra-cellular distribution. Eur J Biochem 1992;210:1045-51.

37. Kleine AH, Glatz JF, Van Nieuwenhoven FA, Van der Vusse GJ. Release of heart fatty acidbinding protein into plasma after acute myocardial infarction in man. Mol Cell Biochem 1992;116:155-62.

38. Glatz JF, Kleine AH, van Nieuwenhoven FA, Hermens WT, Van Dieijen-Visser MP, et al. Fatty-acid-binding protein as a plasma marker for the estimation of myocardial infarct size in humans. Br Heart $J$ 1994;71:135-40.

39. Tanaka T, Hirota Y, Sohmiya K, Nishimura S, Kawamura K. Serum and urinary human heart fatty acid-binding protein in acute myocardial infarction. Clin Biochem 1991;24:195-201.

40. Robers M, Van der Hulst FF, Fischer MAJG, Roos W, Salud CE, et al. Development of a rapid microparticle-enhanced turbidimetric immunoassay for plasma fatty acid-binding protein, an early marker of acute myocardial infarction. Clin Chem 1998;44:1564-7.

41. Katrukha A, Bereznikova A, Filatov V. Development of sandwich time-resolved immunofluorometric assay for the quantitative determination of fatty acid-binding protein (FABP). Clin Chem 1997;43:S106 (abstract).

42. Wolfrum C, Buhlmann C, Rolf B, Börchers T, Spener F. Variation of liver-type fatty acidbinding protein content in the human hepatoma liver-type cell line HepG2 by peroxisome proliferators and antisense RNA affects the rate of fatty acid-uptake. Biochim Biophys Acta 1999;1437:194-201.

43. Pelsers MMAL, Morovat A, Alexander GJM, Hermens WT, Trull AK, et al. Liver fatty acidbinding protein as a sensitive serum marker of acute hepatocellular damage in liver transplant recipients. Clin Chem 2002;48:2055-7.

44. Gollin G, Marks WH. Elevation of circulating intestinal fatty acid-binding protein in luminal contents-initiated model of NEC. J Pediatr Surg 1993;28:367-70. 
45. Lieberman JM, Sacchettini J, Marks C, Marks WH. Human intestinal fatty acid binding protein: report of an assay with studies in normal volunteers and intestinal ischemia. Surgery 1997;121:335-42.

46. Guthmann F, Börchers T, Wolfrum C, Wustrack T, Bartholomaus S, et al. Plasma concentration of intestinal- and liver-FABP in neonates suffering from necrotizing enterocolitis and in healthy preterm neonates. Mol Cell Biochem 2002;239:227-34.

47. Pelsers MMAL, Namiot Z, Kisiekewski W, Namiot A, Januszkiewicz M, et al. Intestinal-type and liver-type fatty acid-binding protein in the intestine: tissue distribution and clinical utility. Clin Biochem 2003;36:529-35.

48. Pelsers M, Hanhoff T, van der Voort D, de Kruijk J, Twijnstra A, et al. Tissue specific types of fatty acid-binding proteins, B- and H-FABP, as novel markers for detection of brain injury. Clin Chem Lab Med 2003;41:P7.98(abstract).

49. Schreiber A, Specht B, Pelsers MMAL, Glatz JFC, Börchers T, et al. Recombinant human heart-type fatty acid-binding protein as standard in immunochemical assays. Clin Chem Lab Med 1998;36:283-8.

50. Aartsen WM, Pelsers MMAL, Hermens WT, Glatz JFC, Daemen MJAP, et al. Heart fatty acid-binding protein and cardiac troponin $\mathrm{T}$ plasma concentrations as markers for myocardial infarction after coronary ligation in mice. Pfluglers Arch. 2000;439:416-22.

51. Pelsers MMAL, Bishop CM, Butler PJ, Glatz JFC. Fatty acid-binding protein content of heart and skeletal muscles of the migratory barnacle goose during development. Am J Physiol 1999;276:R637-43.

52. Luiken JFP, Arumugam Y, Dyck D, Bell RC, Pelsers MMAL, et al. Increased rates of fatty acid uptake and plasmalemmal fatty acid transporters in obese zucker rats. $J$ Biol Chem 2001;276:40567-73.

53. Pelsers MMAL. Performance of fatty acid-binding protein as plasma marker for tissue injury. PhD thesis Maastricht University 2004.

54. Hayashida N, Chihara S, Tayama E, Akasu K, Kai E, Kawara T, et al. Influence of renal function on serum and urinary heart fatty acid-binding protein levels. J Cardiovasc Surg 2001;42:735-40.

55. De Groot MJM, Wodzig KWH, Simoons ML, Glatz JFC, Hermens WT. Measurement of myocardial infarct size from plasma fatty acid-binding protein or myoglobin, using individually estimated clearance rates. Cardiovasc Res 1999;44:315-24.

56. Sorichter S, Mair J, Koller A, Pelsers MMAL, Puschendorf B, et al. Early assessment of exercise induced skeletal muscle injury using plasma fatty acid-binding protein. Br J Sports Med 1998;32:121-4.

57. Katrukha A, Bereznikova A, Filatov V, et al. Improved detection of minor ischemic cardiac injury in patients with unstable angina by measurement of cTnI and fatty acid-binding protein (FABP). Clin Chem 1999;45:A139 (abstract).

58. Pagani F, Bonora R, Bonetti G, Panteghini M. Evaluation of a sandwich enzyme-linked immunosorbent assay for the measurement of serum heart fatty acid-binding protein. Ann Clin Biochem 2002;39:404-5.

59. Gollin G, Marks C, Marks WH. Intestinal fatty acid-binding protein in serum and urine reflects early ischemic injury to the small bowel. Surgery 1993;113:545-51.

60. Marks WH, Gollin G. Biochemical detection of small intestinal allograft rejection by elevated circulating levels of serum intestinal fatty acid-binding protein. Surgery 1993;114:206-10.

61. Kanda T, Fujii H, Tani T, Marukami H, Suda T. Intestinal fatty acid-binding protein is a useful diagnostic marker for mesenteric infarction in humans. Gastroenterology 1996;110:339-43.

62. Azzazy HME, Christenson RH. Cardiac markers of acute coronary syndromes: is there a case for point-of-care testing? Clin Biochem 2002;35:13-27.

63. Ghani F, Wu AHB, Graff L, Petry C, Armstrong G, et al. Role of heart-type fatty acidbinding protein in early detection of acute myocardial infarction. Clin Chem 2000;46:718-9. 
64. Chan CPY, Sum KW, Cheung KY, Glatz JFC, Sanderson JE, et al. Development of a quantitative lateral-flow assay for rapid detection of fatty acid-binding protein. $J$ Immunol Methods 2003;279:91-100.

65. Chan CPY, Cheng WS, Glatz JFC, van der Voort D, Hempel A, et al. Early diagnosis of acute myocardial infarction using immunosensors and immunotests. Anal Letters 2003;36:1987-2004.

66. Watanabe T, Ohkubo Y, Matsuoka H, Kimura H, Sakai Y, et al. Development of a simple whole blood panel test for detection of human heart-type fatty acid-binding protein. Clin Biochem 2001;34:257-63.

67. Siegmann-Thoss C, Renneberg R, Glatz JFC, Spener F. Enzyme immunosensors for diagnosis of myocardial infarction. Sens Actuators 1996;B30:71-6.

68. Schreiber A, Feldbrügge R, Key G, Glatz JFC, Spener F. An immunosensor based on disposable electrodes for rapid estimation of fatty acid-binding protein, an early marker for myocardial infarction. Biosens Bioelectron 1997;12:1131-7.

69. Key G, Schreiber A, Feldbrügge R, McNeil CJ, Jorgenson P, et al. Multicenter evaluation of an amperometric immunosensor for plasma fatty acid-binding protein: an early marker for myocardial infarction. Clin Biochem 1999;32:229-31.

70. O'Regan TM, Pravda M, O’Sullivan CK, Guilbault GG. Development of a disposable immunosensor for the detection of human heart-type fatty acid-binding protein in whole blood using screen-printed carbon electrodes. Talanta 2002;57:501-10.

71. Robers M, Rensink IJAM, Hack CE, Aarden LA, Reutelingsperger CP, et al. A new principle for rapid immunoassay of proteins based on in situ precipitate-enhanced ellipsometry. Biophys $J$ 1999;76;2769-76.

72. Maatman R, Van Kuppevelt T, Veerkamp J. Two types of fatty acid-binding protein in human kidney. Isolation, characterization and localization. Biochem J 1991;273:759-66.

73. Van Nieuwenhoven FA, Kleine AH, Wodzig KWH, Hermens WT, Kragten HA, et al. Discrimination between myocardial and skeletal muscle injury by assessment of the plasma ratio of myoglobin over fatty acid-binding protein. Circulation 1995;92:2848-54.

74. Maatman RG, Van der Westerlo EM, Van Kuppevelt TH, Veerkamp JH. Molecular identification of the liver- and the heart-type fatty acid-binding proteins in human and rat kidney. Use of the reverse transcriptase polymerase chain reaction. Biochem J 1992;288:285290.

75. Myers-Pane SC, Hubbel T, Pu L, Schnütgen F, Börchers T, et al. Isolation and characterization of two fatty acid-binding proteins from mouse brain. $J$ Neurochem 1996; 66:1648-56.

76. Sellner PA, Chu W, Glatz JFC, Berman NEJ. Developmental role of fatty acid-binding proteins in the mouse brain. Dev Brain Res 1995;89:33-46.

77. Gordon JI, Elshourbagy N, Lowe JB, Liao WS, Alpers DH, Taylor JM. Tissue specific expression and developmental regulation of two genes coding for rat fatty acid-binding proteins. J Biol Chem 1985;260:1995-8.

78. Shield HM, Bates ML, Bass NM, Best CJ, Alpers DH, et al. Light microscopic immunocytochemical localization of hepatic and intestinal types of fatty acid-binding proteins in rat small intestine. J Lipid Res 1986;27:549-57.

79. Lam KT, Borkan S, Claffey KP, Schwartz JH, Chobanian AV, et al. Properties and differential regulation of two fatty acid-binding proteins in the rat kidney. $J$ Biol Chem 1988;263:15762-8.

80. Hermens WT. Mechanisms of protein release from injured heart muscle. Dev Cardiovasc Med 1998;205:85-98.

81. World Health Organization, Working Group on the Establishment of Ischemic Heart Disease Registers. Report of the Fifth Working Group, Copenhagen. In: Report no. Eur 8201 (5). World Health Organization, Geneva, 1971.

82. Alpert JS, Thygesen K, Antman E, Bassand JP. Myocardial infarction redefined-A consensus document of The Joint European Society of Cardiology/American College of Cardiology 
Committee for the redefinition of myocardial infarction. J Am Coll Cardiol. 2000;36:959-69.

83. Keeley EC, Boura JA, Grines CL. Primary angioplasty versus intravenous thrombolytic therapy for acute myocardial infarction: a quantitative review of 23 randomised trails. Lancet 2003;361:13-20.

84. Maxwell SRJ, Lip GYH. Reperfusion injury: a review of the pathophysiology, clinical manifestations and therapeutic options. Int J Cardiology 1997;58:95-117.

85. Glatz JFC, Van der Vusse GJ, Simoons M, Kragten JA, Van Dieijen-Visser MP, Hermens WT. Fatty acid-binding protein and the early detection of myocardial infarction. Clin Chim Acta 1998;272:87-92.

86. Hermens WT, Pelsers MMAL, Mullers-Boumans ML, de Zwaan C, Glatz JFC. Combined use of markers of muscle necrosis and fibrinogen conversion in the early differentiation of myocardial infarction and unstable angina. Clin Chem 1998;44:890-2.

87. Wodzig KW, Kragten JA, Modrzejewski W, Gorski J, Van Dieijen-Visser MP, et al. Thrombolytic therapy does not change the release ratios of enzymatic and non-enzymatic myocardial marker proteins. Clin Chim Acta 1998;272:209-23.

88. Mair J. Progress in myocardial damage detection: New biochemical markers for clinicians. Crit Rev Clin Lab Sci 1997;34:1-66.

89. Kragten JA, Hermens WT, Van Dieijen-Visser MP. Cardiac Troponin T release into plasma after acute myocardial infarction: only fractional recovery compared with enzymes. Ann Clin Biochem 1996;33:314-23.

90. Glatz JFC, Haastrup B, Hermens WT, de Zwaan C, Barker J, et al. Fatty acid-binding protein and the early detection of acute myocardial infarction: the EUROCARDI multicenter trail. Circulation 1997;96:I-215(abstract).

91. Okamoto F, Sohmiya K, Okhura Y, Kawamura K, Asayama K, et al. Human heart-type cytoplasmic fatty acid-binding protein (H-FABP) for the diagnosis of acute myocardial infarction. Clinical evaluation of H-FABP in comparison with myoglobin and creatine kinase isoenzyme MB. Clin Chem Lab Med 2000;38:231-8.

92. Sanders GT, Schouten Y, de Winter RJ, et al. Evaluation of human heart type fatty acidbinding protein assay for the early detection of myocardial infarction. Clin Chem 1998;44:A132(abstract).

93. Panteghini M, Bonora R, Pagani F, et al. Heart fatty acid-binding protein is useful in early and myocardial-specific diagnosis of acute myocardial infarction. Clin Chem 1997;43:S157(abstract).

94. Abe S, Saigo M, Yamashita T, et al. Heart fatty acid-binding protein is useful in early and myocardial-specific diagnosis of acute myocardial infarction. Circulation 1996;94:I-323 (abstract).

95. Chan CPY, Sanderson JE, Glatz JFC, Cheng WS, Hempel A, et al. A superior early myocardial infarction marker - human heart-type fatty acid-binding protein. Zeitschr Kardiol 2004; in press.

96. Haastrup B, Gill S, Kristensen SR, Jorgensen PJ, Glatz JFC, et al. Biochemical markers of ischemia for the early identification of acute myocardial infarction without ST segment elevation. Cardiol 2002;94:254-61.

97. Kaptein WA, Zwaagstra JJ, Venema K, Korf J. Continuous ultraslow microdialysis and ultrafiltration for subcutaneous sampling as demonstrated by glucose and lactate measurements in rats. Anal Chem 1998;70:4696-4700.

98. Van der Voort D, Pelsers MMAL, Korf J, Hermens WT, Glatz JFC. Development of a displacement immunoassay for human heart-type fatty acid-binding protein in plasma; the basic conditions. Biosens Bioelectr 2003;19:465-71.

99. Setsuta K, Seino Y, Ogawa T, Arao M, Miyatake Y, et al. Use of cytosolic and myofibril markers in the detection of ongoing myocardial damage in patients with chronic heart failure. Am J Med 2002;113:717-22. 
100. Sato Y, Yamada T, Taniguchi R, Nagai K, Makiyama T, et al. Persistently increased serum concentrations of cardiac troponin $\mathrm{T}$ in patients with idiopathic dilated cardiomyopathy are predictive of adverse outcomes. Circ 2001;103:369-74.

101. Seino Y, Tomita Y, Takano T, Hayakawa H. Early identification of cardiac events with serum troponin T in patients with unstable angina. Lancet 1993;342:1236-7.

102. Seino Y, Tomita Y, Hoshino K, Setsuta K, Takano T, et al. Pathophysiological analysis of serum troponin $\mathrm{T}$ release kinetics in evolving ischemic myocardial injury. Jpn Circ J 1996;60:265-76.

103. Smith N. The clinical utility of FABP in acute coronary syndromes. PhD thesis University of Newcastle 2001.

104. Setsuta K, Arao M, Miyataka Y, Imair T. Elevated levels of heart-type fatty acid-binding protein in patients with chronic heart failure. Circulation 1999;100:I-649 (abstract).

105. Komamura K, Okhura Y, Asayama K, et al. Heart-type fatty acid-binding protein: An important predictor of cardiac events in heart failure. J Card Fail 1999;5(suppl 1):19(abstract).

106. Goto T, Takase H, Toriyama T, Sigiura T, Sato K, et al. Circulating concentrations of cardiac proteins indicate the severity of congestive heart failure. Heart 2003;86:1303-7.

107. Pelsers MMAL, Bakker J, Pinto YM, Van Dieijen-Visser MP, Hermens WT, et al. Plasma fatty acid-binding protein outperforms troponin $\mathrm{T}$ as a sensitive marker for myocardial injury in heart failure. Clin Chem Lab Med 2003;41:S11.6(abstract).

108. Wodzig KWH, Kragten JA, Hermens WT, Glatz JFC, van Dieijen-Visser MP. Estimation of myocardial infarct size from plasma fatty acid-binding protein. Influence of renal function. Eur J Clin Chem Biochem 1997;35:191-8.

109. Hermens WT, Van der Veen FH, Willem GM, Reneman RS. Complete recovery in plasma of enzymes lost from the heart after permanent coronary occlusion in the dog. Circulation 1990;81:649-59.

110. Simoons ML, Serruys PW, Van den Brand M, et al. Early thrombolysis in acute myocardial infarction: limitation of infarct size and improved survival. J Am Coll Cardiol 1986;7:717-28.

111. Van der Laarse A. Rapid estimation of myocardial infarct size. Cardiovas Res 1999;44:247-8.

112. Ishii J, Nagamura Y, Nomura M, Wang JH, Taga S, et al. Early detection of successful coronary reperfusion based on serum concentration of human heart-type cytoplasmic fatty acid-binding protein. Clin Chim Acta 1997;262:13-27.

113. De Lemos JA, Antman EM, Morrow DA, Llevadot J, Giugliano RP, et al. Heart-type fatty acid-binding protein as a marker of reperfusion after thrombolytic therapy. Clin Chim Acta 2000;298:85-97.

114. De Groot MJM, Muijtjens AMM, Simoons ML, Hermens WT, Glatz JFC. Assessment of coronary reperfusion in patients with myocardial infarction using fatty acid-binding protein concentrations in plasma. Heart 2001;85:278-85.

115. De Groot MJM, Kragten HJA, Hermens WT, Glatz JFC. Assessment of coronary reperfusion by cardiac marker proteins in patients with myocardial infarction. $C V R \& R$ 2003;24:144-9.

116. Fransen EJ, Maessen JG, Hermens WT, Glatz JFC. Demonstration of ischemiareperfusion injury separate from postoperative infarction in CABG patients. Ann Thoracic Surg 1998;65:48-53.

117. Hayashida N, Chihara S, Akasu K, Oda T, Tayama E, et al. Plasma and urinary levels of heart fatty acid-binding protein in patients undergoing cardiac surgery. Jpn Circ J 2000;64:18-22.

118. Suzuki K, Sawa Y, Kadoba K, Takahashi T, Ichikawa H, et al. Early detection of cardiac damage with fatty acid-binding protein after cardiac operations. Ann Thorac Surg 1998;65:54-8. 
119. Petzold T, Feindt P, Sunderdiek U, Boeken U, Fischer Y, et al. Heart-type fatty acidbinding protein (H-FABP) in the diagnosis of myocardial injury in coronary artery bypass grafting. Eur J Cardiothor Surg 2001;19:859-64.

120. Yoshimoto K, Tanaka T, Somiya K, Tsuji R, Okamoto F, et al. Human heart-type cytoplasmic fatty acid-binding protein as an indicator of acute myocardial infarction. Heart Vessels 1995;10:304-9.

121. Clarkson PM, Nosaka K, Braun B. Muscle function after exercise-induced muscle damage and rapid adaptation. Med Sci Sports Exerc 1992;24:512-20.

122. Driessen-Kletter MF, Amerlink GJ, Bar PR, van Gijn J. Myoglobin is a sensitive marker of increased muscle membrane vulnerability. J Neurol 1990;237:234-8.

123. Rodenburg JB, Bar PR, De Boer RW. Relations between muscle soreness and biochemical and functional outcomes of eccentric exercise. J Appl Physiol 1993;74:2976-83.

124. Yuan Y, Kwong AW, Kaptein WA, Fong C, Tse M, et al. The responses of fatty acidbinding protein and creatine kinase to acute and chronic exercise in junior rowers. Res $Q$ Exerc Sport 200374:277-83.

125. Dufour DR, Lott JA, Nolte FS, Gretch DR, Koff RS, et al. Diagnosis and monitoring of hepatic injury. Performance characteristics of laboratory tests. Clin Chem 2000;46:12;202749.

126. Trull AK. The clinical validation of novel strategies for monitoring transplant recipients. Clin Biochem 2001;34:3-7.

127. Trull AK, Facey SP, Rees GW, Wight DGD, Noble-Jamieson G, et al. Serum $\alpha$ glutathione S-transferase, a sensitive marker of hepatocellular damage associated with liver allograft rejection. Transplant 1994;58:1345-51.

128. Hughes VF, Trull AK, Gimson A, Friend PJ, Jamieson N, et al. Randomized trial to evaluate the clinical benefits of serum $\alpha$ - glutathione s-transferase concentration monitoring after liver transplantation. Transplant 1997;64:1446-52.

129. Becket GJ, Hayles JD. Plasma gluthatione S-transferase: biomedical applications. $A d v$ Clin Chem 1993;30:281-3.

130. Platz KP, Mueller AR, Haller GW, Müller C, Wenig M, et al. Determination of $\alpha$ - and $\pi$ Gluthatione-S-transferase will improve monitoring after liver transplantation. Transplant proc 1997; 29:2827-9.

131. Ockner RK, Manning JA, Kane JP. Fatty acid-binding protein. Isolation from rat liver, characterization and immunochemical quantification. Biol Chem 1982;257:7872-8.

132. Gordon JI, Alpers DH, Ockern RJ, Strauss AW. The nucleotide sequence of rat liver fatty acid-binding protein mRNA. J Biol Chem 1983;258:3356-63.

133. Ascher N, Stock PG, Baumgarder GL, Payne WD, Najarian JS. Infection and rejection of primary hepatic transplant in 93 consecutive patients treated with triple immunosuppressive therapy. Surg Gynecol Obstet 1988;167:474-84.

134. European FK506 Multicentre Liver Study Group. Randomized trial comparing tacrolimus (FK506) and cyclosporin in prevention of liver allograft rejection. Lancet 1994;344:423-8.

135. Neuhaus P, Bechstein WO, Blumhardt G, Wiens M, Lemmens P, et al. Comparison of FK506- and cyclosporine-based immunosuppresion in primary orthopic liver transplantation: a single center experience. Transplant 1995;59:31-40.

136. Wight DGD. Pathology of liver transplantation. In: Symmeers WS, ed. Systemic Pathology, Volume 11: Liver, biliary tract and exocrine pancreas. New York: Churchill Livingstone, 1994;543-96.

137. Adams D. Mechanisms of liver allograft rejection in man. Clin Sci 1990;78:353-50.

138. Gok MA, Pelsers MMAL, Glatz JFC, et al. Use of two biomarkers of renal ischemia to assess machine-perfused non-heart-beating donor kidneys. Clin Chem 2003;49:172-5.

139. Gok MA, Pelsers MMAL, Glatz JFC, et al. Comparison of perfusate activities of glutathione-S-transferase, alanine aminopeptidase and fatty acid-binding protein in the assessment of non-heart-beating donor kidneys. Ann Clin Biochem 2003:40:252-8. 
140. Gok MA, Pelsers MMAL, Glatz JFC, Shenton BK, Buckley PE, et al. Creatinine clearance and viability biomarkers of machine perfused non-heart-beating donors: is there a correlation? Transplant Proc 2003;35:768.

141. Gok MA, Pelsers MMAL, Glatz JFC, et al. Do tissue damage markers used to assess machine perfused NHBD kidneys predict long term renal function post-transplant? Clin Chim Acta 2003;338:33-43.

142. Pelsers MMAL, Davies D. Fatty acid-binding protein: a new biomarker of nephrotoxicity in the rat (abstract). In: Abstract Book to the 4th international conference on lipid binding proteins, Maastricht the Netherlands, 2001.

143. Kievit JK, Pelsers MMAL, Daemen MARC, Buurman WA, Kootstra G, et al. Quantification of early ischemic renal injury in the rat using fatty acid-binding protein (abstract). In: Abstract Book of the European Meeting on Biomarkers of Organ Damage and Dysfunction, Cambridge UK, April 3-7, 2000:107.

144. Roels HA, Hoet P, Lison D. Usefulness of biomarkers of exposure to inorganic mercury, lead, or cadmium in controlling occupational and environmental risks of nephrotoxicity. Ren Fail 1999;21:251-62.

145. Diamond GL, Zalups RK. Understanding renal toxicity of heavy metals. Toxicol Pathol 1998;26:92-103.

146. Girardi G, Elias MM. Verapamil protection against mercuric chloride-induced renal glomular injury in rats. Toxicol Appl Pharmacol 1988;152:360-5.

147. Bernard A, Lauwerys R. Epidemiological application of early markers of nephrotoxicity. Toxicol Lett 1989;46:293-306.

148. Price RG, Taylor SA, Chivers I, et al. Development and validation of new screening tests for nephrotoxic effects. Hum Exp Toxicol 1996;15:S10-19.

149. Taylor SA, Chivers ID, Price RG, Arce-Tomas M, Milligan P, et al. The assessment of biomarkers to detect nephrotoxicity using an integrated database. Environ Res 1997;75:23-33.

150. Loeb W. The measurement of renal injury. Toxicol Pathol 1998;26:26-8.

151. Terasaki P, Cho Y, Cecka J. Strategy for eliminating the kidney shortage. Clin Transpl 1997;11:265-7.

152. Balupuri S, Buckley P, Snowden C, Mustafa M, Sen B, et al. The trouble with kidneys derived from the non-heart-beating donor: a single center 10-year experience. Transplant 2000;15:842-6.

153. Kievit J, Oomen A, Janssen M, van Kreel B, Heineman E, et al. Viability assessment of non-heart-beating donor kidneys by alpha glutathione S- transferase in the machine perfusate. Transplant Proc 1997;29:1381-3.

154. Matteucci E, Carmellini M, Bertoni C, Boldrini E, Mosca F, et al. Urinary excretion rates of multiple renal indicators after kidney transplantation: clinical significance for early graft outcome. Ren Fail 1998;20:325-30.

155. Andersen LW, Landrow L, Baek L, Jansen E, Baker S. Association between gastric intramucosal $\mathrm{pH}$ and splanchnic endotoxin, antibodies to endotoxin, and tumor necrosis factor alpha concentrations in patients undergoing cardiopulmonary bypass. Crit Care Med 1993;21:210.

156. Sacchetini JC, Hauft SM, Van Camp SL, Cistola DP, Gordon JL. Developmental and structural studies of an intracellular lipid binding protein expressed in the ileal epithelium. $J$ Biol Chem 1990;265:19199-207.

157. Ockner RK, Manning JA. Fatty acid-binding protein in small intestine. J Clin Invest 1974;54:326-38.

158. Robinson JW, Mirkovitch V. The recovery of function and microcirculation in small intestinal loops following ischemia. Gut 1972;13:784-9.

159. Morrisey PE, Gollin G, Marks WH. Small bowel allograft rejection detected by serum intestinal fatty acid-binding protein is reversible. Transplant 1996;61:1451-55. 
160. Holmes JH, Lieberman JM, Probert CB, Marks WH, Hill ME, et al. Elevated intestinal fatty acid-binding protein and gastrointestinal complications following cardiopulmonary bypass: a preliminary analysis. J Surg Res 2001;100:192-6.

161. Kuo PC, Morris J, Marks WH, Lieberman JM, Johnson DL, et al. Human syngeneic intestinal transplantation: evaluation of enterocyte viability with serum levels of intestinal fatty acid-binding protein. Clin Transplant 1996;10:282-6.

162. Sonnino R, Ereso G, Arcuni J, Franson R. Human intestinal fatty acid-binding protein in peritoneal fluid is a marker of intestinal ischemia. Trans Proc 2000;32:1280.

163. Kanda T, Fujii H, Fujita M, Sakai Y, Ono T, Hatakeyama K. Intestinal fatty acid-binding protein is available for diagnosis of intestinal ischemia: immunochemical analysis of two patients with ischaemic intestinal diseases. Gut 1995;36:788-91.

164. Kanda T, Fujii H, Tani T, Marukami H, Suda T. Intestinal fatty acid-binding protein is a useful diagnostic marker for mesenteric infarction in humans. Gastroenterology 1996;110:339-43.

165. Edelson MB, Sonnino R, Bagwell C, Lieberman J, Marks WH, et al. Plasma intestinal fatty acid-binding protein in neonates with necrotizing entercolitis: a pilot study. J Ped Surg 1999;34:1453-7.

166. Kaufman SS, Lyden ER, Marks WH, Lieberman J, Sudan DL. Lack of utility of intestinal fatty acid-binding protein levels in predicting intestinal allograft rejection. Transplant 2001;71:1058-60.

167. Sakai Y. Quantitative measurement of liver fatty acid-binding protein in the human gastrointestinal tract. Nipp Sho Gak Zas 1990;87:2594-604.

168. Lamers KJB, Vos P, Verbeek MM, Rosmalen F, van Geel WJA, et al. Protein S-100B, neuron-specific enolase (NSE), myelin basic protein (MBP) and glial fibrillary acidic protein (GFAP) in cerebrospinal fluid (CSF) and blood of neurological patients. Brain Res Bull 2003;61:261-4.

169. Rothermundt M, Peters M, Prehn JHM, Arolt V. S100B in brain damage and neurodegeneration. Microsc Res Tech 2003;60:614-32.

170. Verbeek MM, De Jong D, Kremer HP. Brain-specific proteins in cerebrospinal fluid for the diagnosis of neurodegenerative diseases. Ann Clin Biochem 2003;40:25-40.

171. Aurrel A, Rosengren LE, Karlsson B, Ollson J, Zbornikove V, Haglid KG. Determination of S-100 and glial fibrillary acidic protein concentration in CSF after brain infarction. Stroke 1991;22:1254-8.

172. Romner B, Ingebrigtsen T, Kongstad P, Borgesen SE. Traumatic brain damage: serum S100 protein measurements related to neuroradiological findings. $J$ Neurotrauma 2000;17:6417.

173. Herrmann M, Vos PE, Wunderlich MT, de Bruijn CH, Lamers KJ. Release of glial tissue specific protein after acute stroke: a comparative analysis of serum concentrations of protein S-100B and glial fibrillary acidic protein. Stroke 2000;31:2670-7.

174. Martens P, Raabe A, Johnsson. Serum S-100 and neuron-specific enolase for prediction of regaining consciousness after global cerebral ischemia. Stroke 1998;29:2363-6.

175. Nakagawa H, Yamada M, Kanayama T, Tsuruzono K, Miyawaki Y, et al. Myelin basic protein in the cerebrospinal fluid of patients with brain tumors. Neurosurgery 1994;34:82533.

176. Nooijen PTGA, Schoonderwaldt HC, Wevers RA, Hommes OR, Lamers KJB. Neuron specific enolase, S-100 protein, myelin basic protein and lactate in CSF in dementia. Dement Geriatr Cogn Disord 1997;8:169-73.

177. Kilminster S, Treasure T, McMillam T, Holt DW. Neuropsychological change and S-100 protein release in 130 unselected patients undergoing cardiac surgery. Stroke 1999;30:186974.

178. Mussack T, Biberthaler P, Kanz KG, Wiedemann E, Gippber-Steppert C, et al. Serum S$100 \mathrm{~B}$ and interleukine- 8 as predictive marker for comparative neurologic outcome analysis of 
patients after cardiac arrest and severe traumatic brain injury. Crit Care Med 2002;30:266974.

179. Missler U, Orlowski N, Nötzold A, Dibbelt L, Steinmeier E, et al. Early elevation of S100B protein in blood after cardiac surgery is not a predictor of ischemic cerebral injury. Clin Chim Acta 2002;321:29-33.

180. Kurtz A, Zimmer A, Schnütgen F, Brüning G, Spener F, Müller T. The expression pattern of a novel gene encoding brain-fatty acid-binding protein correlates with neuronal and glial cell development. Development 1994;120:2637-49.

181. Feng L, Hatten ME, Heintz N. Brain lipid-binding protein (BLBP): a novel signaling system in the developing mammalian CNS. Neuron 1994;12:895-908.

182. Pu L, Igbavboa U, Wood WG, Roths JB, Kier AB, et al. Expression of fatty acid-binding protein is altered in aged mouse brain. Mol Cell Biochem; 1999;198:69-78.

183. Heuckeroth RO, Birkenmeier EH, Levin MS, Gordon JI. Analysis of the tissue specific expression, developmental regulation, and linkage relationships of a rodent gene encoding heart fatty acid-binding protein. $J$ Biol Chem 1987;262:9709-17.

184. Zimmermann-Ivol CG, Burkhard PR, Le Floch-Rohr J, Allard L, Hochstrasser DF, et al. Fatty acid-binding protein as a serum marker for the early diagnosis of stroke: A pilot study. Mol Cell Proteomics 2004;3:66-72.

185. Guillaume E, Zimmerman C, Burkhard P, Hochstrasser D, Sanches J. A Potential cerebrospinal fluid and plasmatic marker for the diagnosis of Creutzfeldt-Jakob disease. Proteomics 2003;3:1495-9.

186. Ryan TJ, Antman EM, Brooks NH, Califf RM, Hillis LD, et al. 1999 Update: ACC/AHA guidelines for the management of patients with acute myocardial infarction: Executive summary and recommendations. Circulation 1999;100:1016-30.

187. Smith SC Jr, Dove JT, Jacobs AK, Kennedy JW, Kereiakes D, et al. ACC/AHA guidelines of percutaneous coronary intervention. Executive summary. $J$ Am Coll Cardiol 2001;37:2215-38.

188. Adams JE, Abendschein DR, Jaffe AS: Biochemical markers of myocardial injury. Is MB creatine kinase the choice for the 1990s? Circulation 1993;88:750-63.

189. Christenson RH, Azzazy HME: Biochemical markers of the acute coronary syndromes. Clin Chem 1998;44:1855-64.

190. Setsuta K, Seino Y, Takahasi N, Ogawa T, Sasaki K, et al. Clinical significance of elevated levels of cardiac troponin $\mathrm{T}$ in patients with chronic heart failure. Am J Cardiol 1999;84:608-11.

191. Sacchettini JC, Hauft SM, Van Camp SL, Cistola DP, Gordon JI. Developmental and structural studies of an intracellular lipid-binding protein expressed in the ileal epithelium. $J$ Biol Chem 1990;265:19199-207.

192. Jones TA, Bergfors T, Sedzik J, Unge T. The three-dimensional structure of the P2 myelin protein. EMBO J 1988;7:1597-604.

193. Schmitt MC, Jamison RS, Orgebin-Christ MC, Ong DE. A novel, testis-specific member of the cellular lipophilic transport protein superfamily, deduced from a complementary deoxyribonucleic acid clone. Biol Reprod 1994;51:239-45.

194. Siegenthaler G, Hotz R, Chattelard-Gruaz D, Jaconi S, Saurat JH. Characterization and expression of a novel human fatty acid-binding protein: the epidermal-type (E-FABP). Biochem Biophys Res Commun 1994;302:363-71.

195. Van Nieuwenhoven FA. Heart fatty acid-binding protein. PhD thesis Maastricht University, Maastricht, Netherlands 1996.

196. Diris JH, Hackeng CM, Kooman JP, Pinto YM, Hermens WT, et al. Impaired renal clearance explains elevated troponin $\mathrm{T}$ fragments in hemodialysis patients. Circulation 2004;109:23-5.

197. Ishii J, Wang JH, Naruse H, Taga S, Kinoshita M, et al. Serum concentrations of myoglobin vs human heart-type cytoplasmic fatty acid-binding protein in early detection of acute myocardial infarction. Clin Chem 1997;43:1372-8 
Chapter 2 


\section{Development of an enzyme-linked immunosorbent assay (ELISA) for heart-type fatty acid-binding protein (H-FABP)}

Part of this chapter is published:

Roos W, Eymann E, Symannek M, Duppenthaler J, Wodzig KWH, Pelsers MMAL, Glatz JFC. Monoclonal antibodies to human heart fatty acid-binding protein. J Immunol Methods 1995;183:149-153.

Wodzig KWH, Pelsers MMAL, van der Vusse GJ, Roos W, Glatz JFC. One-step enzyme-linked immunosorbent assay (ELISA) for plasma fatty acid-binding protein. Ann Clin Biochem 1997;34:263-8. 


\subsection{Abstract}

To allow a more rapid determination of H-FABP concentration in plasma, a direct noncompetitive (sandwich-type) ELISA was developed. Monoclonal antibodies to human HFABP were characterized via BIAcore analyses and used to develop an immunochemical assay in order to determine H-FABP concentrations in plasma or tissue. Out of 13 hybridomas, 2 monoclonal IgG1 antibodies were selected to develop a non-competitive sandwich ELISA. As both antibodies recognize different epitopes, simultaneous incubation of the H-FABP containing sample with the immobilized capture antibody and the conjugated detector antibody is permitted, resulting in a total performance time of 45 min. The detection limit of $0.3 \mu \mathrm{g} / \mathrm{L}$ permits an accurate determination of $\mathrm{H}-\mathrm{FABP}$ in healthy individuals and the detection of micro-necrosis in patients with unstable angina or heart failure. In conclusion we can state that the newly developed immunoassay for $\mathrm{H}$ FABP is rapid and sensitive and is now being evaluated for determination of plasma $\mathrm{H}$ FABP concentrations in patients entering the coronary care unit for the early assessment or exclusion of myocardial injury.

\subsection{Introduction}

Heart-type fatty acid-binding protein (H-FABP) is a newly introduced plasma marker of acute myocardial infarction (AMI) in man. ${ }^{(1-6)}$ The plasma kinetics of H-FABP (15 kD) closely resemble those of myoglobin $(\mathrm{Mb})(18 \mathrm{kD})$ in that significantly elevated plasma concentrations are found within $3 \mathrm{~h}$ after AMI which generally return to normal values within 12 to $24 \mathrm{~h}^{(5-7)}$ These features make H-FABP a useful biochemical marker especially for the early assessment or exclusion of $\mathrm{AMI}^{(5-6)}$ and for monitoring of a recurrent infarction. ${ }^{(7)}$ Recent studies show that micro-necrosis in either patients with unstable angina or heart failure can be detected with the plasma concentration of $\mathrm{H}$ FABP (see Chapter 6). Since H-FABP released from the heart after AMI is quantitatively recovered in plasma, $\mathrm{H}-\mathrm{FABP}$ can also be used to estimate infarct size. ${ }^{\left({ }^{8}\right)}$ As with $\mathrm{Mb}$, small quantities of H-FABP are also expressed in skeletal muscle, which are released into the circulation following injury (see Chapter 7). ${ }^{(7)}$ However, as the ratio of the tissue concentrations of $\mathrm{Mb}$ over $\mathrm{H}-\mathrm{FABP}$ is different in heart (2 to 5) compared to skeletal muscles (20 to 70), the assessment of this ratio in plasma allows the discrimination between myocardial and skeletal muscle injury. ${ }^{(7)}$

The clinical application to confirm or exclude AMI soon after admission requires a rapid test system. Mass detection by an immunochemical method is preferred. However, reported immunochemical assays for H-FABP take about 2 to 5 h to complete. ${ }^{(2,3,5,9)}$ Here we describe the characterization of monoclonal antibodies to human H-FABP and the development of a highly sensitive one-step sandwich-ELISA for H-FABP determination in plasma or tissue with a total performance time of only $45 \mathrm{~min}$.

\subsection{Material and methods}

\subsubsection{Plasma samples}

\section{Healthy subjects}

For determination of the reference range of H-FABP in serum and plasma, blood samples were withdrawn from 79 healthy subjects (61 men, median age 35, range 20 to 51 years; 
and 18 women, median age 38, range 23 to 51 years). Subjects were taking no medication. Blood samples were obtained between 9.00 and 12.00 and collected in glass tubes (preparation of serum). For 10 subjects, a second blood sample was collected in glass tubes containing dry heparin (preparation of plasma). After centrifugation at $1500 \mathrm{~g}$ for $10 \mathrm{~min}$, serum or plasma was collected and stored at $-70^{\circ} \mathrm{C}$ until analysis.

\section{Myocardial injury patients}

Comparison of the present assay with a previously described immunochemical assay for H-FABP was carried out on serial plasma samples from patients with confirmed AMI. We studied six randomly selected patients (five men, one woman, median age 58, range 52 to 61 years) from a population of 22 patients enrolled in another study. ${ }^{(10)}$ Patients were admitted to the coronary care unit with chest pain and ST segment elevation $(>1$ $\mathrm{mm}$ ) typical of AMI within $6 \mathrm{~h}$ after the onset of symptoms. They received thrombolytic therapy consisting of 1.5 million units of streptokinase given by infusion in $40 \mathrm{~min}$. Blood samples, obtained at admission and subsequently at nine time points (final sample was taken $24 \mathrm{~h}$ after admission), were collected in dry-heparin containing tubes and processed exactly as described above.

\subsubsection{Isolation and purification of H-FABP}

Human H-FABP, used as standard in the calibration curves, was purified from heart autopsies by gelpermeation and anionexchange chromatography as described previously. ${ }^{(5)}$ In addition, we used recombinant human H-FABP, kindly donated from Dr. T. Börchers (University of Münster, Germany).

\subsubsection{Monoclonal-antibody based assay of H-FABP}

For measurement of H-FABP in serum and plasma, a direct non-competitive ELISA of the antigen capture type (sandwich ELISA) was developed, based on the use of monoclonal antibodies (mAb). Thirteen mAbs, all of subtype IgG1 and directed against purified human H-FABP, were raised by the classical hybridoma technology and characterized by surface plasmon resonance analysis using a Pharmacia Biacore sensor (Fig. 3.1). The mAbs recognized five distinct (three independent and two overlapping) epitopes on human H-FABP (Fig. 3.2), and showed no cross-reactivity with human intestinal-type and human liver-type FABP. Seven of the mAbs were selected on the basis of stability of the hybridoma clone and affinity for H-FABP. Affinity constants for $\mathrm{H}-\mathrm{FABP}$ interactions with these selected mAbs range from $5 \times 10^{7}$ to $3 \times 10^{8} \mathrm{M}^{-1}$. ${ }^{(11)}$ Antibodies were stored in buffer solution at $-20^{\circ} \mathrm{C}$, and conjugated antibodies at $4{ }^{\circ} \mathrm{C}$, and were found to be stable for more than 48 months. Cross-reactivity of the selected mAbs 66E2 and 67D3 with H-FABP from different species was evaluated and described in Chapter 4. 


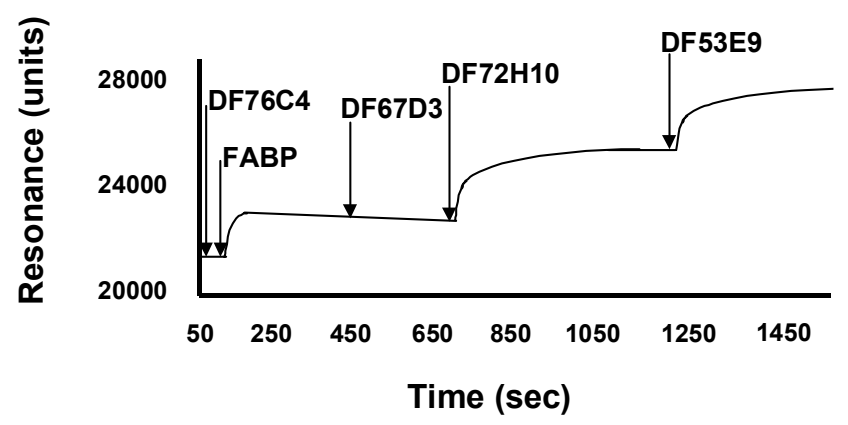

Figure 3.1 Sensorgram demonstrating the binding of 3 monoclonal antibodies to H-FABP.

Assays were carried out on polystyrene Maxisorb microtitre plates (Nunc) (Fig. 3.3). Plates were coated overnight at $4^{\circ} \mathrm{C}$ with $200 \mathrm{ng}$ per well of catcher mAb 67D3 in $100 \mu \mathrm{L}$ $0.1 \mathrm{M}$ sodium bicarbonate buffer ( $\mathrm{pH}$ 9.4). The wells then were washed five times $(200$ $\mu \mathrm{L} /$ well) with phosphate-buffered saline containing $0.1 \%(\mathrm{w} / \mathrm{v})$ bovine serum albumin (A4503 from Sigma, St. Louis, MO, USA) and 0.05\% Tween 20 (PBT). Thereafter, 50 $\mu \mathrm{L}$ of a solution containing $180 \mathrm{ng} / \mathrm{ml}$ of detection mAb 66E2 conjugated with horseradish peroxidase (HRP; P8375 from Sigma, St Louis, MO, USA) and recognizing a different epitope group on H-FABP was added to each well. This was immediately followed by $50 \mu \mathrm{L}$ of the standard containing 0 to $12 \mu \mathrm{g} / \mathrm{L} \mathrm{H}-\mathrm{FABP}$ ( 0 to $600 \mathrm{pg}$ purified human $\mathrm{H}$-FABP per well), or $50 \mu \mathrm{L}$ of minimal 5-fold prediluted human serum or plasma samples. After incubation for $30 \mathrm{~min}$ at $37^{\circ} \mathrm{C}$ or $60 \mathrm{~min}$ at room temperature, the plates were washed five times with PBT and incubated with $100 \mu \mathrm{L} /$ well of a substrate solution consisting of $20 \mathrm{mM}$ tetramethyl benzidine (TMB, Lucron Bioproducts, Gennep, The Netherlands). After $5 \mathrm{~min}$, the reaction was stopped with $50 \mu \mathrm{L} /$ well of $2 \mathrm{M} \mathrm{H}_{2} \mathrm{SO}_{4}$. The absorbance was read at $450 \mathrm{~nm}$ using a Titertek Multiscan MKII spectrophotometer (Labsystems, Helsinki, Finland). The detection limit of the assay was $0.3 \mu \mathrm{g} / \mathrm{L}$.

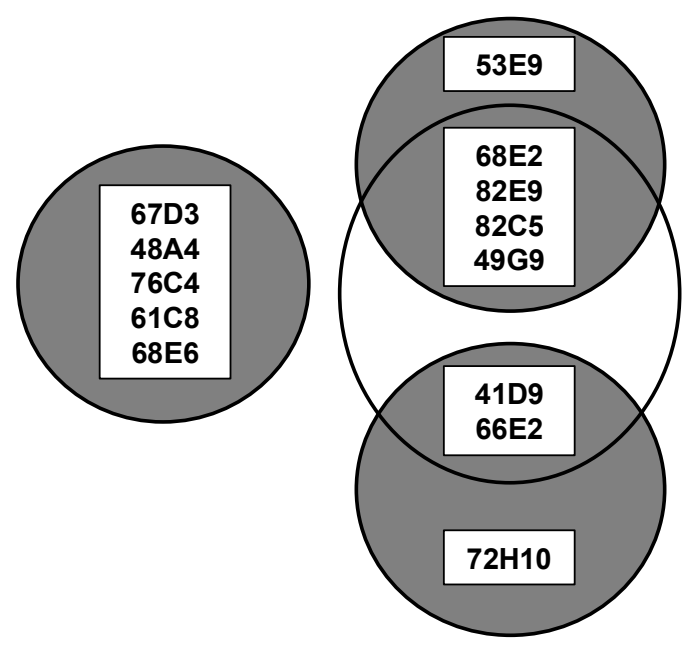

Figure 3.2 Two dimensional representation of the binding pattern of the monoclonal antibodies to the different epitopes of $\mathrm{H}-\mathrm{FABP}$

\subsubsection{Polyclonal-antibody based assay of H-FABP}

The newly developed mAb based sandwich ELISA was compared with the polyclonalantibody (pAb) based ELISA described previously. ${ }^{(5)}$ The latter assay was carried out in a similar manner as outlined above, but used mono-specific polyclonal IgG antibodies isolated by affinity chromatography from rabbit serum. After coating the wells with 
capture antibody, blocking with 5\% (w/v) bovine serum albumin, and addition of standards or diluted plasma samples, incubation took place for $1.5 \mathrm{~h}$ at room temperature. The plates were then washed five times with PBT and incubated for another $1.5 \mathrm{~h}$ with 60 ng/well biotinylated mono-specific polyclonal rabbit IgG (detector antibody) in $100 \mu \mathrm{L}$ $\mathrm{PBT} /$ well. Thereafter, the plates were washed again and detection of the biotinylated antibody bound to H-FABP was achieved by incubation with $100 \mu \mathrm{L}$ of streptavidineHRP (Pierce, Rockford, IL, USA) for $1 \mathrm{~h}$, followed by washing and development with $100 \mu \mathrm{L} /$ well of a substrate solution consisting of $20 \mathrm{mM}$ O-phenylene diamine (OPD)

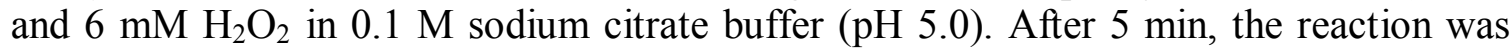
stopped with $50 \mu \mathrm{L}$ of $2 \mathrm{M} \mathrm{H}_{2} \mathrm{SO}_{4}$. The absorbance was read at $492 \mathrm{~nm}$ and the detection limit of the assay was $1 \mu \mathrm{g} / \mathrm{L} .{ }^{(5)}$

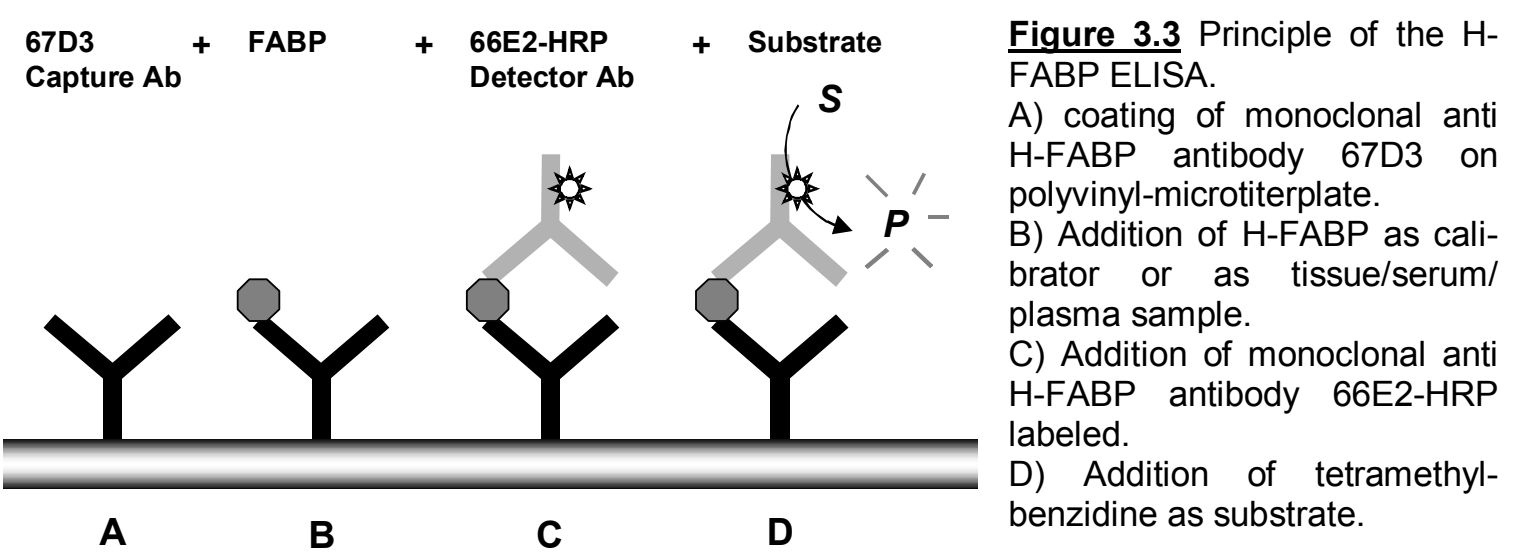

\subsubsection{Statistical analysis}

Data are presented as mean \pm SD. Statistical analysis of differences between groups was performed with Student's t-test. $p<0.05$ was considered statistically significant.

\subsection{Results and Discussion}

\subsubsection{Performance of monoclonal antibody-based assay}

The seven different mAbs selected on the basis of stability of the hybridoma clone and affinity for H-FABP were tested as both capture and as detector antibodies (the latter conjugated with HRP) in different combinations by a checkerboard ELISA approach. For combinations of $\mathrm{mAbs}$ directed against distinct epitope groups, a similar linear H-FABP standard curve was found, with the absorbance at a specific H-FABP concentration differing maximally two-fold from the observed with the eventually selected mAbs. Optimal results were obtained with the combination of mAb 67D3 immobilized on the microtitre plate and mAb 66E2 conjugated with HRP as detector antibody. The standard curve was found to be linear up to $12 \mu \mathrm{g} / \mathrm{L} \mathrm{H}-\mathrm{FABP}$, and no differences were found between a standard curve with FABP isolated from human heart and that recorded with recombinant human FABP (the absorbance with the latter was $97 \pm 5 \%(n=3)($ Fig. 3.4). 


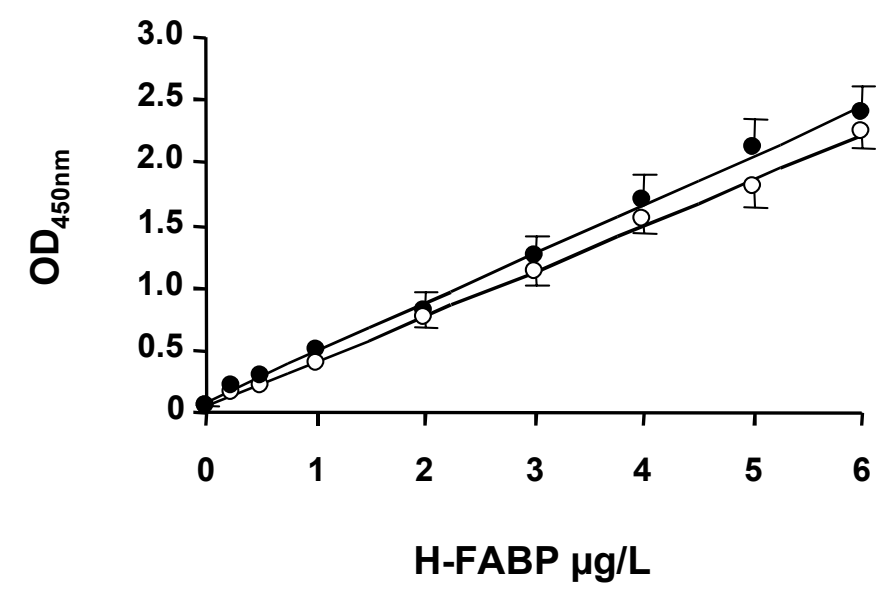

Figure 3.4 Standard curves for the one-step H-FABP ELISA using monoclonal antibodies and tissue derived $(\bullet)$ or recombinant (०) human H-FABP. Data refer to mean $( \pm S D)$ for ten curves.

\subsubsection{Assay variation and linearity of dilution}

To estimate the imprecision of the assay, two different human plasma pools with elevated H-FABP concentrations were analyzed three times each on 10 consecutive days. For the pooled plasma sample with a relatively low plasma H-FABP concentration $(26 \mu \mathrm{g} / \mathrm{L})$ the calculated intra-assay coefficient of variation (CV) was $6 \%$ and the inter-assay CV $11 \%$, for the pooled plasma sample with a high H-FABP concentration $(280 \mu \mathrm{g} / \mathrm{L})$ the intraassay $\mathrm{CV}$ was $5 \%$ and the inter-assay CV $9 \%$.

The linearity of dilution was investigated using the plasma samples with a high H-FABP concentration. Serial dilutions (up to 10-fold) were made in saline. After correction of the measured value for the dilution factor, recovery was calculated to be between 97 and $113 \%$. Recovery of pure human H-FABP added in various quantities to plasma of healthy individuals amounted to $97 \pm 5 \%$ as mean \pm SD for 12 determinations.

\subsubsection{Method comparison}

Fifty-four plasma samples with H-FABP concentrations between 2 and $310 \mu \mathrm{g} / \mathrm{L}$, as measured with the existing immunochemical assay based on polyclonal antibodies, were re-evaluated using the newly developed mAb ELISA. The correlation was $y=1.04 \mathrm{x}+0.23$ $(r=0.99)$. Agreement between the two methods was analyzed in a difference plot according to Bland and Altman (Fig. 3.5). ${ }^{(12)}$ The accuracy was assessed by calculating the $95 \%$ confidence interval (mean \pm 2 SEM) for the mean of differences $(4.3 \mu \mathrm{g} / \mathrm{L})$. As this interval ( -0.8 to $7.8 \mu \mathrm{g} / \mathrm{L})$ includes zero, there is no evidence of systematic bias. With respect to the precision, the scatter of the differences was found to increase as the average increased (Fig. 3.3), but the limits of agreement (mean $\pm 2 \mathrm{SD}$ i.e., -21.5 and $30.2 \mu \mathrm{g} / \mathrm{L}$ ) are acceptably small. We conclude that there is agreement between the methods.

To determine the stability of H-FABP in plasma samples on storage and following repeated cycles of freezing and thawing, six plasma samples with H-FABP concentrations ranging from 25 to $250 \mu \mathrm{g} / \mathrm{L}$ were assayed freshly, then divided into aliquots and stored at $4^{\circ} \mathrm{C}$ for 1 week, and at $-20^{\circ} \mathrm{C}$ and $-70^{\circ} \mathrm{C}$ for 12 months. When compared to fresh plasma samples, no significant alterations in H-FABP concentration were found in these samples as analyzed in the given time periods. Repeated freezing and thawing (tested up to eight times) also had no influence on measured H-FABP concentrations (data not shown). The high stability of H-FABP in plasma agrees with the observations made by Ohkaru. ${ }^{(9)}$ 


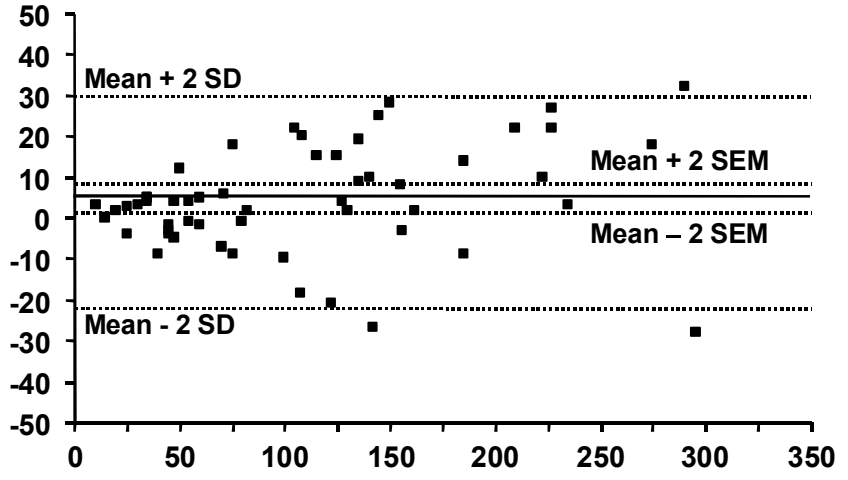

Average $[(m A b+p A b) / 2, \mu g / L]$
Figure 3.5 Difference plot of 54 plasma samples in which H-FABP concentration was measured by a monoclonal antibody (mAb) and polyclonal antibody based (pAb) immunochemical assay. Mean difference (solid line), 95\% confidence interval for the mean difference [mean (2SEM) dashed line], and limits of agreement [mean (2SD) dashed line] are shown.

\subsubsection{Reference values}

In this study, the mAb ELISA was used to measure the H-FABP concentrations in serum and heparinized plasma samples from 79 apparently healthy individuals (Table 3.1). Men showed a slightly higher H-FABP concentration $(1.6 \pm 0.8 \mu \mathrm{g} / \mathrm{L}$ for $\mathrm{n}=61)$ than women $(1.4 \pm 0.5 \mu \mathrm{g} / \mathrm{L}$ for $\mathrm{n}=18)$, but the difference was not statistically significant. H-FABP concentrations measured in serum did not differ from those measured in heparinized plasma (plasma/serum ratio $1.04 \pm 0.8$ for $n=10$ ). Serum H-FABP showed a slight increase with age e.g., mean values for men and women aged 41 to 51 years were $60 \%$ and $50 \%$ higher, than in men and women of 20 to 30 years (Table 3.1$)$ respectively $(p<0.05)$. The increase of serum H-FABP with age most likely relates to the fact that H-FABP is eliminated from the circulation predominantly by renal clearance ${ }^{(3,5)}$ and renal function generally decreases with age. ${ }^{(13)}$ In addition, release of H-FABP from muscle tissue may increase with age. For plasma myoglobin, which is also cleared from the circulation mostly by the kidneys ${ }^{(14)}$, a similar increase with age has been found. ${ }^{(15,16)}$ In Chapter 5 , we present a larger and more detailed study on H-FABP and myoglobin normal values to establish a cut-off value for detection of myocardial injury.

Table 3.1 H-FABP concentration in serum samples from healthy subjects

\begin{tabular}{|c|c|c|c|c|}
\hline \multicolumn{5}{|c|}{ FABP concentration ( $\mu \mathrm{g} / \mathrm{L})$} \\
\hline Sex & Age (years) & $n$ & Mean (SD) & Range \\
\hline \multirow[t]{4}{*}{ Women } & $20-30$ & 5 & $1.0(0.6)$ & $0.3-1.7$ \\
\hline & $31-40$ & 8 & $1.6^{*}(0.4)$ & $1.0-2.2$ \\
\hline & $41-51$ & 5 & $1.6(0.6)$ & $0.7-2.4$ \\
\hline & All & 18 & $1.4(0.5)$ & $0.3-2.4$ \\
\hline \multirow[t]{4}{*}{ Men } & $20-30$ & 19 & $1.2(0.4)$ & $0.5-2.0$ \\
\hline & $31-40$ & 30 & $1.8^{*}(0.9)$ & $0.9-5.0$ \\
\hline & $41-51$ & 12 & $1.8^{\star}(0.9)$ & $0.9-3.7$ \\
\hline & All & 61 & $1.6(0.8)$ & $0.5-5.0$ \\
\hline
\end{tabular}

*Significantly different from value at age 20-30 $p<0.05$ 
For all subjects investigated, the mean $\pm \mathrm{SD}$ value of serum $\mathrm{H}-\mathrm{FABP}$ was $1.6 \pm 0.8 \mu \mathrm{g} / \mathrm{L}$ $(\mathrm{n}=79)$. This value agrees with a study of Tanaka ${ }^{(3)}$ who reported H-FABP in plasma from healthy subjects to vary between 0 and $2.8 \mu \mathrm{g} / \mathrm{L}(\mathrm{n}=86)$ although later the same group reported a higher reference concentration of $3.6 \pm 1.8 \mu \mathrm{g} / \mathrm{L}(\mathrm{n}=100) .{ }^{(9)}$ Our present value however is lower than that determined previously in our laboratory, $9 \pm 5 \mu \mathrm{g} / \mathrm{L}$ $(n=72) .{ }^{(5)}$ This difference may be related to the use of less specific polyclonal antibodies in the ELISA at that time compared to the currently used monoclonal antibodies, which could have caused overestimated values in case of low predilution of samples (5-fold predilution was used). The lower sensitivity of this previous assay may also have contributed to the difference in reference concentration.

\subsubsection{Evaluation}

A non-competitive sandwich ELISA for H-FABP was developed which is based on the use of monoclonal capture and detector antibodies recognizing different epitope groups on the protein molecule. This permits the simultaneous incubation of the H-FABP containing serum or plasma sample with the (immobilized) capture antibody and the (conjugated) detector antibody, thus limiting the number of steps of the assay procedure. In addition, an incubation time of $30 \mathrm{~min}$ at $37^{\circ} \mathrm{C}$ appeared sufficient, which relates to the antibodies having been selected for a high affinity for H-FABP. Since detection of the HRP conjugate is very rapid ( $<7 \mathrm{~min}$ ), the entire procedure, including washing steps and reading of the absorbance can be performed routinely within $45 \mathrm{~min}$, which is markedly faster than the $5 \mathrm{~h}$ needed to complete the previously developed polyclonal antibodybased immunochemical assay. ${ }^{(5)}$ However, for convenience in analyzing large amounts of samples in our lab, we incubated $1 \mathrm{~h}$ at room temperature.

The newly developed immunoassay showed a low intra- and inter-assay variation and an excellent comparability with the previously described assay for H-FABP. ${ }^{(5)}$ The detection limit of $0.3 \mu \mathrm{g} / \mathrm{L}$ is markedly lower than that of reported direct ${ }^{(5,9,17)}$ or competitive immunoassays ${ }^{(2,3)}$ and is sufficiently low to permit the accurate determination of H-FABP concentrations in plasma of healthy individuals (see Chapter 5). The measuring range allows samples from patients with AMI to be routinely diluted 25 -fold and include $>90 \%$ of reported H-FABP concentrations in pathological samples $(7.5$ to $300 \mu \mathrm{g} / \mathrm{L}) .^{(2,3,5-8)}$ The use of monoclonal antibodies ensures a source of antibodies of constant quality so that the assay can be easily automated. In view of the good performance of H-FABP as plasma marker for early phase diagnosis of AMI, the immunoassay is currently being used for determination of H-FABP in blood from patients entering the coronary care unit of the hospital. Furthermore, the H-FABP ELISA is useful as reference assay for even more rapid assay systems as H-FABP immunosensors are currently being developed. ${ }^{(18)}$

\subsection{Rerefences}

1. Glatz JFC, Van Bilsen M, Paulussen RJA, Veerkamp JH, Van der Vusse GJ, et al. Release of fatty acid-binding protein from isolated rat heart subjected to ischemia and reperfusion or to the calcium paradox. Biochim Biophys Acta 1988;961:148-52.

2. Knowlton AA, Burrier RE, Brecher P. Rabbit heart fatty acid-binding protein: isolation, characterization and application of a monoclonal antibody. Circ Res 1989;65:981-8.

3. Tanaka T, Hirota Y, Sohmiya K, Nishimura S, Kawamura K. Serum and urinary human heart fatty acid-binding protein in acute myocardial infarction. Clin Biochem 1991;24:195-201. 
4. Adams JE, Abendschein DR, Jaffe AS. Biochemical markers of myocardial injury. Is MB creatine kinase the choice for the 1990s? Circulation 1993;88:750-63.

5. Kleine AH, Glatz JFC, Van Nieuwenhoven FA, Van der Vusse GJ. Release of heart fatty acid-binding protein into plasma after acute myocardial infarction in man. Moll Cell Biochem 1992;116:155-62.

6. Tsuji R, Tanaka T, Sohmiya K, Hirota Y, Yoshimoto K, et al. Human heart-type cytoplasmic fatty acid-binding protein in serum and urine during hyperacute myocardial infarction. Int $J$ Cardiol 1993;41:209-17.

7. Van Nieuwenhoven FA, Kleine AH, Wodzig KWH, Hermens WT, Kragten JA, et al. Discrimination between myocardial and skeletal muscle injury by assessment of the plasma ratio of myoglobin over fatty acid-binding protein. Circulation 1995;92:2848-54.

8. Glatz JFC, Kleine AH, van Nieuwenhoven FA, Hermens WT, Van Dieijen-Visser MP, et al. Fatty acid-binding protein as a plasma marker for the estimation of myocardial infarct size in humans. Br Heart $J$ 1994;71:135-40.

9. Ohkaru Y, Asayama K, Ishii H, Nishimura S, Sunahara N, et al. Development of a sandwich enzyme-linked immunosorbent assay for the determination of human heart-type fatty acidbinding protein in plasma and urine by using two different monoclonal antibodies specific for human heart-type fatty acid-binding protein. J Immunol Methods 1995;178:99-111.

10. Kragten JA, Hermens WT, Van Dieijen-Visser MP. Cardiac troponin T release into plasma after acute myocardial infarction: only fractional recovery compared with enzymes. Ann Clin Biochem 1996;33:314-23.

11. Roos W, Eymann E, Symannek M, Duppenthaler J, Wodzig KWH, et al. Monoclonal antibodies to human heart fatty acid-binding protein. J Immunol Methods 1995;183:149-53.

12. Bland JM, Altman DG. Statistical methods for assessing agreement between two methods of clinical measurement. Lancet 1986;1:307-10.

13. Wissenschaftliche Tabellen Geigy, Teilband Körperflussigkeiten, 8th edn. Basel, Switzerland, 1977:98-101.

14. Rabkin R, Dahl DC. Renal uptake and disposal of proteins and peptides. In: Audus KL, Raub TJ. Biological barriers to protein delivery. New York: Plenum Press. 1993:299-338.

15. Chen IW, David R, Maxon HR, Sperling M, Stein EA. Age-, sex-, and race-related differences in myoglobin concentrations in the serum of healthy persons. Clin Chem 1980;26:1864-8.

16. Chapelle JP, Lemache K, El Allaf M, El Allaf D, Piérard L. Fast determination of myoglobin in serum using a new radial partition immunoassay. Clin Biochem 1994;24:423-8.

17. Brothers G, Cardone B, Mangion J, Styba G, Jackowski G, et al. Development and characterization of monoclonal and polyclonal antibodies to human heart fatty acid-binding proteins. Clin Chem 1995;41:588.

18. Van der Voort D, Pelsers MMAL, Korf J, Hermens WT, Glatz JFC. Development of a displacement immunoassay for human heart-type fatty acid-binding protein in plasma: the basic conditions. Biosens Bioelectron 2003,19:465-71. 
Chapter 3 


\section{Application of the H-FABP immunoassay in animal research}

Data on migration effects in goose, fatty acid metabolism in diabetic heart, and infarct size measurement in mice, were published in:

Pelsers MMAL, Bishop CM, Butler PJ, Glatz JFC. Fatty acid-binding protein content of heart and skeletal muscles of the migratory barnacle goose during development. Am J Physiol 1999;276:R637-43.

Pelsers MMAL, Lutgerink J, Nieuwenhoven FA, Tandon NN, van der Vusse GJ, et al. A sensitive immunoassay for fatty acid translocase (CD36) using phage antibodies selected on cell transfectants: abundant presence of FAT/CD36 in cardiac and red skeletal muscle and upregulation in diabetes. Biochem $J$ 1999;3:407-14.

Aartsen WM, Pelsers MMAL, Hermens WT, Glatz JFC, Daemen MJAP, et al. Heart fatty acid-binding protein and cardiac troponin $\mathrm{T}$ plasma concentrations as markers for myocardial infarction after coronary ligation in mice. Pfluglers Arch 2000;439:416-22. 


\subsection{Abstract}

Heart-type fatty acid-binding protein (H-FABP) is a cytoplasmic transporter protein of long-chain fatty acids. Because fatty acid metabolism is an important subject of research, applying different human and animal study protocols, we developed a direct noncompetitive (sandwich-type) ELISA for the quantification of H-FABP in plasma and tissue samples. The aim of this chapter was to show the applicability of the ELISA in different studies of H-FABP regulation and diagnostic use in several animal model systems. Cross-reactivity of the selected monoclonal antibodies was measured with recombinant and purified H-FABPs from different species. The assay was then applied in tissue and plasma samples to study either fatty acid metabolism or the use of H-FABP as diagnostic marker for heart and skeletal muscle injury. The monoclonal antibodies recognize H-FABP in most tested species. Cross-reactivity compared to the purified human H-FABP ranged from $5 \%$ to $66 \%$ for horse, dog, cattle, mouse, rat and goose respectively. Duck, chicken and woodpigeon H-FABP could not be detected. Variations in H-FABP tissue content, due to changes in fatty acid metabolism, were induced by extensive flight, development, streptozotocin induced diabetes, and hibernation. Diagnostic use of H-FABP as plasma marker was observed for skeletal muscle injury in racehorses and myocardial injury in mice.

From these studies we can conclude that H-FABP is a well-conserved protein during evolution and the newly developed immunoassay for human H-FABP can be applied for several animal model systems, because cross-reactivity of the monoclonal anti-human HFABP antibodies in different species is sufficient.

\subsection{Introduction}

The transport of sufficient amounts of long-chain fatty acids between tissues and within tissue cells is of vital importance to fulfill various physiological functions like intestinal uptake of dietary fatty acids, energy production from fatty acid oxidation, incorporation of fatty acids into complex lipids like phospholipids and cholesterolesters, fatty acylation of specific proteins and the signaling function of fatty acids and metabolites. ${ }^{(1)}$ In blood and interstitial fluid, albumin is the main transporter of fatty acids, while on the cellular level, FABP is the protein involved in cytoplasmic transport of these compounds. ${ }^{(1,2)}$ Fatty acid translocase (FAT/CD36) and plasmalemmal FABP $\left(\mathrm{FABP}_{\mathrm{pm}}\right)$ are associated with the membrane and facilitate the translocation of fatty acids from the interstitial space into the cytoplasm (Fig. 4.1)..$^{(3,4)}$

Long-chain fatty acids are the main source of energy supply of the heart and therefore the regulation of fatty acid uptake and transport, especially the role of H-FABP, and the regulation of the fatty acid metabolism in heart is a subject of continued interest. Therefore, we developed a direct non-competitive (sandwich-type) ELISA for the determination of heart-type FABP (H-FABP) concentration in plasma or tissue, as described in Chapter 3. H-FABP is expressed in various species during evolution as described by Schaap et al. ${ }^{(5)}$ and the aims of this study were (i) to measure crossreactivity of the anti-human $\mathrm{H}-\mathrm{FABP}$ antibodies with other H-FABPs and (ii) to evaluate the applicability of the ELISA in different animal studies investigating H-FABP regulation and/or its diagnostic utility. H-FABP is also released into the circulation after cell death and can therefore be used as a plasma marker for the detection of tissue injury. 


\section{Interstitial space}

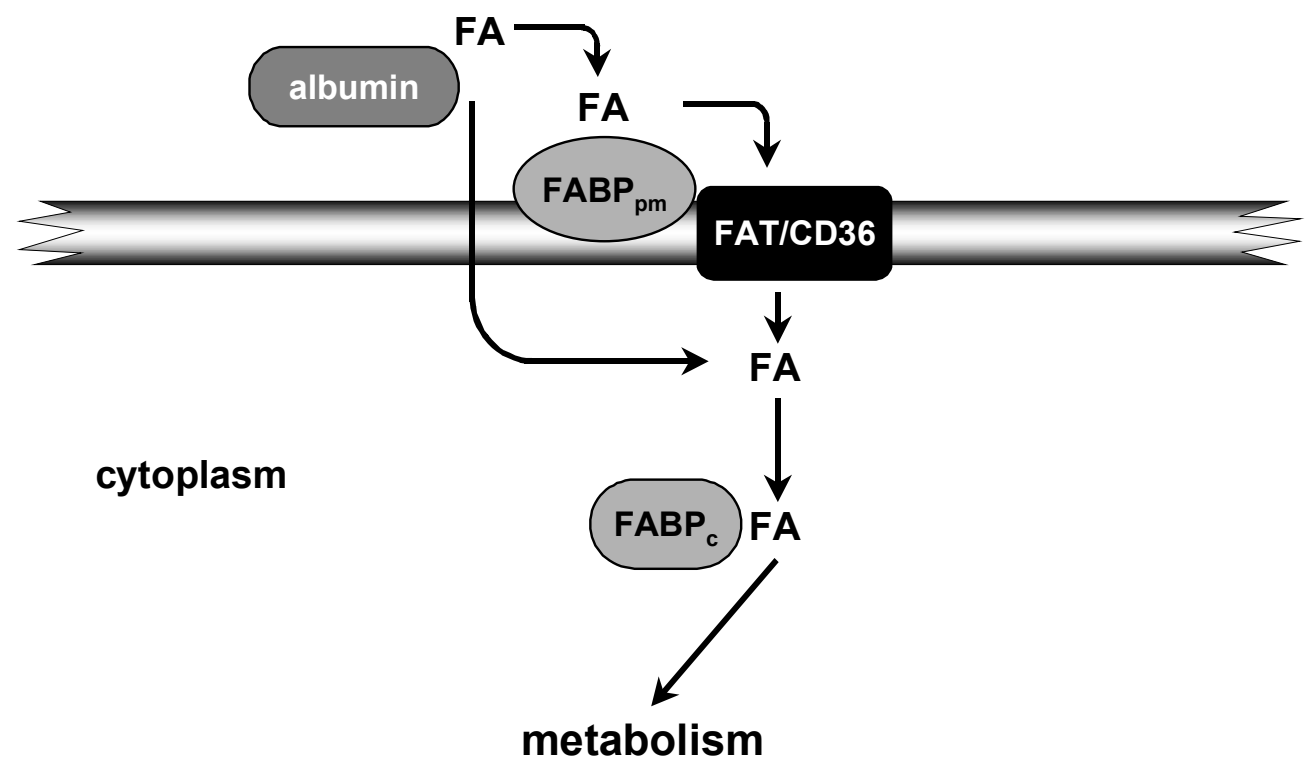

Figure 4.1 Overview of cellular fatty acid metabolism expressing membrane transport proteins fatty acid-translocase (FAT/CD36) and plasmalemmal FABP $\left(F A B P_{p m}\right)$ and intracellular fatty acidbinding protein (FABP).

\subsection{Materials and methods}

\subsubsection{Tissues and serum/plasma}

Heart and skeletal muscle samples from goose, duck, sparrow, woodpigeon, chicken, crow, starling, rat, squirrel, and salmon were homogenized $(3-16 \% \mathrm{w} / \mathrm{v})$ in SET-buffer (0.25 M sucrose, $10 \mathrm{mM}$ EDTA, $10 \mathrm{mM}$ Tris, $\mathrm{pH}$ 7.4) using an Ultra-Turrax homogenizer (IKA Werke, Breisgau, Germany). After sonication, samples were centrifuged (5 min, $1000 \mathrm{~g}$ ) and supernatant (cytoplasmic proteins) and pellet (membrane fractions) were stored at $-80^{\circ} \mathrm{C}$ until further analyses.

\subsubsection{Isolation and purification of H-FABP}

Human H-FABP, used as standard in the calibration curves, was purified from heart autopsies by gel permeation and anion exchange chromatography as described previously. ${ }^{(6)}$ Essentially, the same procedure was used to purify H-FABP from goose ${ }^{(7)}$, horse-, rat-, mouse and dog H-FABP (data not shown). In addition, we used recombinant human-, mouse- and bovine H-FABP as well as human intestinal-type FABP (I-FABP), kindly donated by Dr. T. Börchers (University of Münster, Germany). Recombinant rat H-FABP was purified according to Schaap et al. ${ }^{(8)}$ Recombinant liver-type FABP (LFABP) was kindly donated by Prof. J. Veerkamp (University of Nijmegen, the Netherlands). 


\subsubsection{Westernblotting and H-FABP ELISA}

For measurement of H-FABP in plasma and tissue, a sandwich type ELISA was developed, based on the use of monoclonal antibodies $(\mathrm{mAb})$, as described in Chapter $3 .{ }^{(9)}$ First, western blotting was performed to evaluate specificity of the anti-human HFABP monoclonal antibodies with H-FABP from different species. Homogenates and purified H-FABP were electroforesed on a $12 \%$ SDS gel and, afterwards, blotted on a nitrocellulose membrane. After blotting, the membrane was washed and blocked with 5\% non-fat dry milk in phosphate buffered saline (PBS). After washing two times with $\mathrm{PBS} / 0.1 \%$ BSA $/ 0.05 \%$ Tween-20 (PBT), $1 / 250$ diluted $\mathrm{mAb}$ 66E2-horseradisch peroxidase labeled was incubated overnight at $4^{\circ} \mathrm{C}$.

After washing, ECL coloring was performed for $30 \mathrm{sec}$. The ELISA was performed with recombinant human H-FABP as standard ( 0 to $12 \mu \mathrm{g} / \mathrm{L}$ ) and crossreactivity with other FABPs was expressed as percentage compared to the standard.

\subsubsection{Statistical analyses}

Data are presented as mean \pm SD. Statistical analysis of differences between groups were performed with Student's t-test. $p<0.05$ was considered to be statistically significant.

\subsection{Results}

\subsubsection{Specificity of the H-FABP mAbs}

Western blot analysis showed that the anti-human H-FABP antibodies specifically recognize H-FABP (Fig. 4.2). H-FABP from duck, woodpigeon and chicken could not be detected. In the ELISA, H-FABP from different species showed different percentages cross-reactivity (Fig. 4.3), ranging from 5 to $66 \%$. Purified or recombinant H-FABP from goose, rat, horse, dog and mouse were used as standard in the ELISA to study metabolic and clinical use.

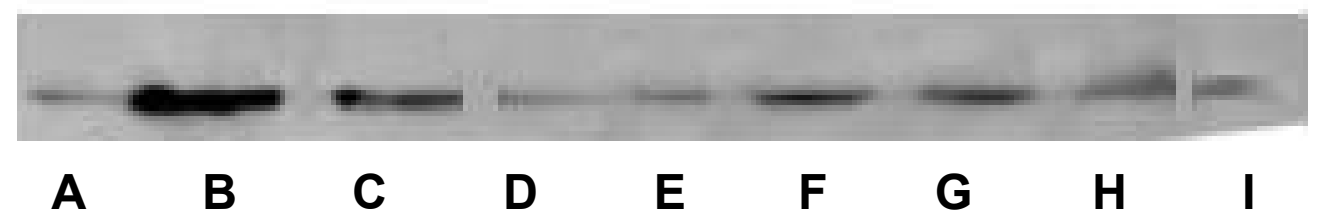

Figure 4.2 Western blot analysis of anti-human H-FABP monoclonal antibodies to: A) Squirrel heart, B) Recombinant Human H-FABP, C) Goose heart, D) Horse heart, E) Crow pectoralis, F) Rat heart, G) Bovine heart, H) Mouse heart, I) Starling heart. 


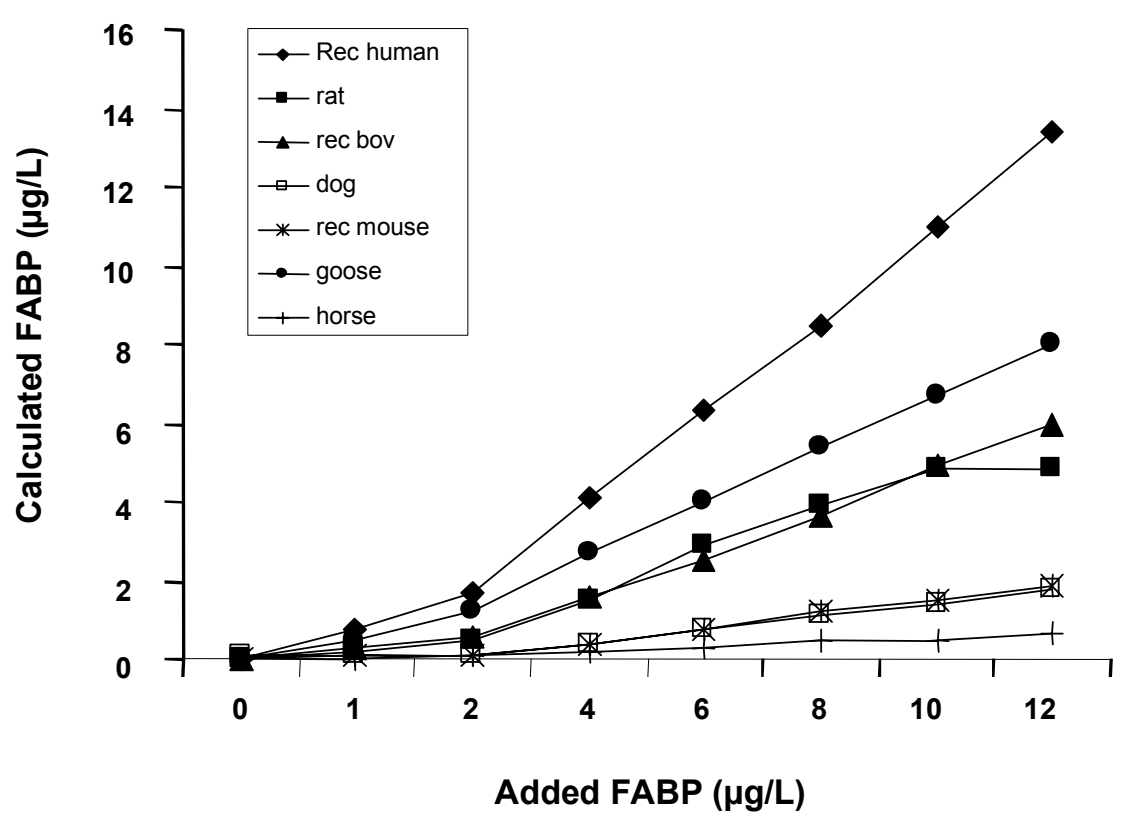

Figure 4.3 Human $\mathrm{H}$ FABP ELISA comparing cross-reactivity of purified dog, goose, and horse H-FABP and recombinant rat, bovine and mouse $\mathrm{H}$ FABP.

\subsection{Animal studies}

\subsubsection{Long-term migratory flight and fatty acid metabolism in goose}

\section{Background}

The long-distance migratory flights of birds are predominantly fuelled by the oxidation of fatty acids, which are sourced primarily from extracellular adipose stores, in contrast to mammals who use intramuscular stores of triacyl-glyceroles. ${ }^{(10,11)}$ Therefore, these fatty acids have to be transported, via the circulatory system, to the mitochondria of the active muscles which is potentially rate limiting. ${ }^{(12,13)}$ An important facilitator of fatty acid transport within the cytoplasm of muscle cells is H-FABP, which serves as an intracellular carrier of long-chain fatty acids. ${ }^{(1)}$ In mammals, the muscular H-FABP content is related to the fatty acid oxidation capacity of the tissue. ${ }^{(14)}$

The aim of this study was to investigate the effects of long-term flight on muscle fatty acid metabolism by measuring H-FABP in samples taken from muscles with different fatty acid oxidation capacity (heart, pectoralis, and semimembranosus muscles) of a longdistance avian migrant, the barnacle goose (Branta leucopsis), at various stages of development. These birds fly approximately $2500 \mathrm{~km}$ from their Artic breeding grounds to winter in southwestern Scotland when the gosling are around $12 \mathrm{wk}$ of age. The pectoralis was divided into peripheral and deep fibers, because it is known that this mixed-type muscle contains a higher percentage of oxidative fibers in the deeper layers than in the peripheral layers.

\section{Material and methods}

Pectoralis, heart and semimembranosus leg muscle tissue was obtained from wild and captive barnacle goose (Branta Leucopsis), before and after migration. Captive barnacle geese were kept in outdoor aviaries at Birmingham, UK. Goslings were sampled at 3 $(n=4), 5(n=8), 6(n=4), 7(n=10)$, and 20 weeks $(n=2)$ of age. Captive adult birds $(n=6)$ that were older than two years and flight restricted so that they could only fly for a few meters, were sampled 12 weeks after the average hatch date for the population of captive 
goslings. Wild barnacle geese were caught using corral nets or small pneumatic-powered cannon nets and sampled in two areas on the western coast of the island of Spitsbergen, Svalbard, Norway. Samples were taken from wild goslings at $7(n=4)$ and 11.5 weeks posthatch $(n=2)$ and from wild adult geese at $7(n=8), 9(n=3)$, and $10.5 \mathrm{wk}(\mathrm{n}=9)$ after the average hatch date for the population of wild goslings.

Duck, sparrow, woodpigeon, chicken, crow, and starling pectoralis and heart samples were kindly donated by Dr. PJ Butler, School of Biological Sciences, University of Birmingham, Birmingham, UK. The H-FABP ratio (pectoralis over heart) of these birds was compared with the ratio in goose. All samples were dissected and directly frozen in liquid nitrogen and stored at $-80^{\circ} \mathrm{C}$ until use. H-FABP was measured with an ELISA as described in Chapter 3, using purified goose H-FABP as calibrator.

\section{Results}

Western blot analyses identified a single goose muscle protein of $15 \mathrm{kD}$ that was able to bind fatty acids (Fig. 4.2). ${ }^{(7)}$ This protein showed a $66 \%$ cross-reactivity with antibodies against human H-FABP (Fig. 4.3). Captive goslings showed no significant changes in $\mathrm{H}-$ FABP content of either the heart $(62.6 \pm 10.6 \mu \mathrm{g} / \mathrm{g} \mathrm{ww})$ or the semimembranosus muscle $(8.4 \pm 1.9 \mu \mathrm{g} / \mathrm{g} \mathrm{ww})$ during development (Fig. 4.4). However, in both peripheral and deep sites within the pectoralis muscle, H-FABP content of samples taken from captive goslings increased around 10-fold throughout development and reached values of 30 to $40 \mu \mathrm{g} / \mathrm{g} \mathrm{ww}$ in fledging goslings at 7 weeks of age (Fig. 4.5). A further twofold higher value was seen in wild but not in captive goslings immediately before migration (12 weeks of age). Similarly, H-FABP content was significantly $(p<0.005)$ higher in pectoralis samples taken from wild adults $(94.3 \pm 3.6 \mu \mathrm{g} / \mathrm{g} \mathrm{ww})$ compared with those from captive adults $(60.5 \pm 3.6 \mu \mathrm{g} / \mathrm{g} \mathrm{ww})$ (Fig. 4.5). These results suggest that the experience of flight activity may be of critical importance in achieving maximal expression of H-FABP in the pectoralis muscles of postfledging and mature geese immediately before migration. The ratio of heart to pectoralis FABP content in sparrow (2.1), starling (0.7) and crow (0.7) was comparable to that of barnacle geese (0.9).

\section{Discussion}

This is the first time that H-FABP has been quantified in the locomotor muscles of a bird that is capable of migrating long distances. In general, the H-FABP content in adult skeletal muscles (pectoralis and semimembranosus) of the barnacle goose were similar $(10-100 \mu \mathrm{g} / \mathrm{g} \mathrm{ww})$ to those found in the skeletal muscles of higher vertebrates such as the rat $(10-300 \mu \mathrm{g} / \mathrm{g} \mathrm{ww})^{(15)}$ and humans $(10-160 \mu \mathrm{g} / \mathrm{g} \mathrm{ww}){ }^{(16)}$ However, the H-FABP content of the cardiac muscle of barnacle geese was markedly lower $(60 \mu \mathrm{g} / \mathrm{g}$ ww $)$ than that of rats $(700 \mu \mathrm{g} / \mathrm{g} \mathrm{ww})^{(15)}$ or humans $(500 \mu \mathrm{g} / \mathrm{g} \mathrm{ww})^{(1)}$, and these differences were not related to differences in tissue protein content. The relative H-FABP content in the heart and pectoralis muscles of other avian species (sparrow, starling, and crow) indicated that these species may have higher H-FABP contents in their cardiac and flight muscles than those found in the barnacle goose but that the ratio of heart to pectoralis FABP content was comparable to that of barnacle geese. Thus, assuming that H-FABP content is a reliable indicator of fatty acid utilization, it would appear that FABP mediated fatty acid transport is lower in barnacle goose heart than in human or rat heart, although the physical demands for migrating geese are at least as high as those of a running mammal. Surprisingly, the H-FABP content of the oxidative heart muscle did not increase during development. Therefore, glucose metabolism needs to be investigated to clarify the energy flux of the heart. 


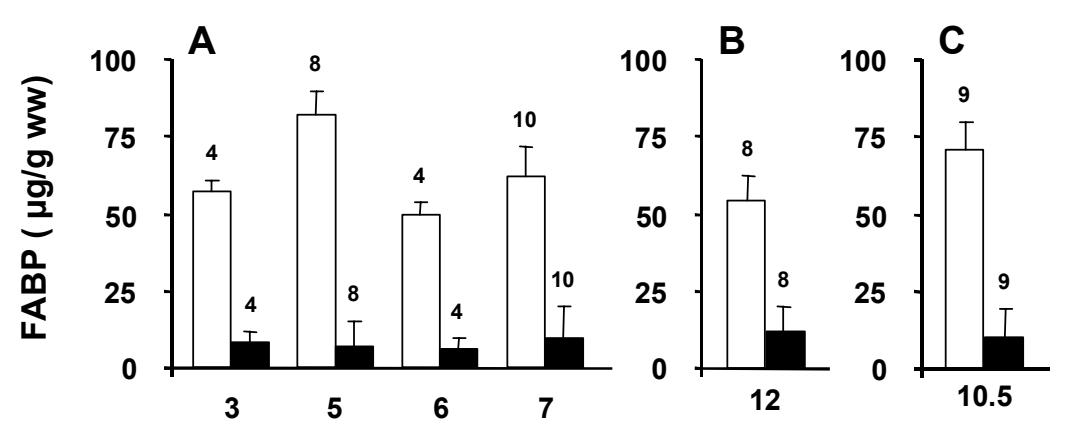

Time elapsed since mean population hatch date (weeks)

Figure 4.4 FABP contents of heart muscle (open bars) and semimembranosus leg muscle (solid bars) at various stages during development in captive goslings $A$ ) and postbreeding captive and wild adults ( $B$ and $C$, respectively). Captive adults had been flight restricted for at least 2 yr. Note that migration takes place $\sim 12$ wk after mean population hatch date of goslings. Data are given as means $\pm \mathrm{SE}$, with numbers over bars representing numbers of samples studied. $w w=w e t$ weight.

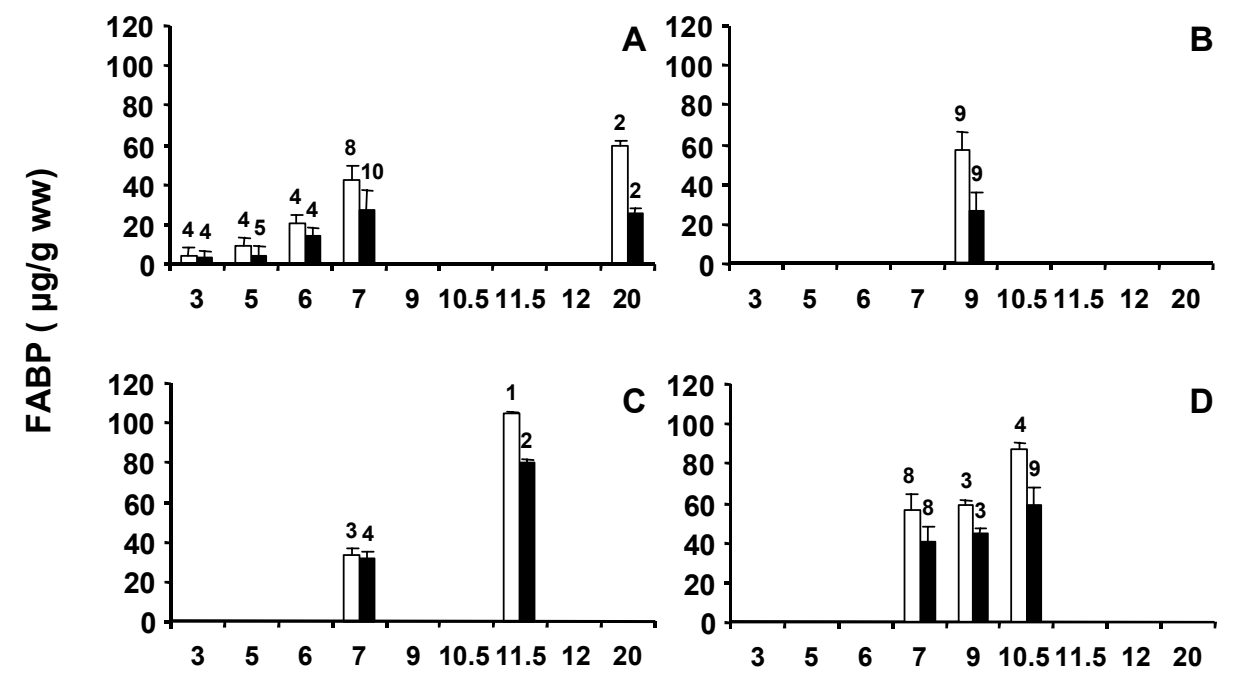

Time elapsed since mean population hatch date (weeks)

Figure 4.5 FABP contents of deep (open bars) and peripheral sites (solid bars) of breast muscle (pectoralis) at various stages during development of captive and wild goslings ( $A$ and $C$, respectively) and of postbreeding captive and wild adult geese ( $B$ and $D$, respectively). Adult geese were at least $2 \mathrm{yr}$ of age. Note that migration takes place $\sim 12 \mathrm{wk}$ after mean population hatch date of goslings. Data are given as means \pm SE, with numbers over bars representing numbers of samples studied. * Significantly $(p<0.05)$ higher values in respective muscle compared with earlier stage of development studied.

\subsubsection{Effect of aging and streptozotocin-induced diabetes in rat heart}

\section{Background}

The cellular expression of FABPs is regulated primarily at the transcriptional level and is responsive to changes in lipid metabolism as induced by several (patho)physiological and pharmaceutical stimuli like diabetes. ${ }^{(17)}$ Because glucose uptake is hampered in diabetes due to either reduced insulin sensitivity (type II) or lack of insulin production (type I), fatty acid oxidation is upregulated to uphold sufficient energy supply to the heart. ${ }^{(18)}$ The 
aim of this study was to investigate the influence of aging and experimental diabetes on energy production in rat heart and skeletal muscles by measuring H-FABP and FAT/CD36 tissue contents.

\section{Material and methods}

H-FABP and FAT/CD36 in heart and skeletal muscles was measured in Wistar rats at birth (day 0), and at 2, 6, 21 and 70 days after birth. Fetal hearts were obtained from pregnant rats sacrificed at day 21 of pregnancy (day -1). Six adult male Wistar rats of ca. $250 \mathrm{~g}$ were rendered diabetic by a single injection of $17.5 \mathrm{mg}$ streptozotocin in $1 \mathrm{ml}$ citrate buffer $(70 \mathrm{mg} / \mathrm{kg}$ body weight) while six control animals received an injection with citrate buffer alone. Three weeks later the animals were sacrificed, and from each animal, heart, soleus, extensor digitorum longus and liver were quickly removed and frozen in liquid nitrogen. For FAT/ CD36 measurements, we developed via phage display technology a sandwich ELISA of the antigen-capture type as described previously. ${ }^{(19)}$ This method is described in more detail in Chapter 11. H-FABP was measured with an ELISA as described in Chapter 3, using recombinant rat $\mathrm{H}-\mathrm{FABP}$ as calibrator.

Results

During rat heart development, the H-FABP protein content increased from $1.2 \pm 0.1 \mathrm{mg} / \mathrm{g}$ protein before birth (day -1) to $5.4 \pm 0.8 \mathrm{mg} / \mathrm{g}$ protein at day 70 (Fig. 4.6). FAT/CD36 increased from $1.7 \pm 0.7 \mathrm{mg} / \mathrm{g}$ protein (day -1) to $3.6 \pm 0.4 \mathrm{mg} / \mathrm{g}$ protein at day 70 (Fig. 4.6). In streptozotocin-induced diabetic rats, the muscle contents of H-FABP decreased from heart to soleus to extensor digitorum longus (EDL) from both control and diabetic rats. In experimental diabetes, a statistically significant increase of H-FABP content was shown in soleus and EDL muscles. Heart also showed an increase in H-FABP content, but due to a large variation, this was not significant (Table 4.1). The FAT/CD36 content of the diabetic heart however, was 2 to 3 fold higher than that of non-diabetic control animals. Oxidative soleus and glycolytic EDL muscles showed markedly lower FAT/CD36 contents than cardiac muscle, but a similar 2-3 fold upregulation in the diabetic animals (Table 4.1).

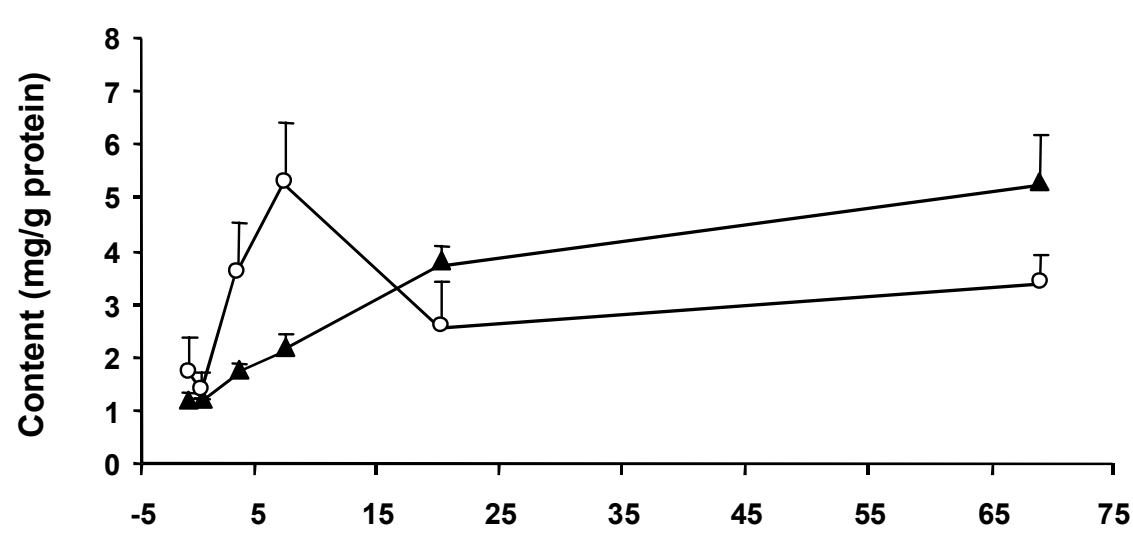

Figure 4.6 FAT and H-FABP protein contents of rat heart during development. Data represent means $\pm S . D$, for five animals. $\triangle \mathrm{H}$-FABP (mg/g of protein); O FAT (mg/g of protein).

Age (days) 


\section{Discussion}

In rat heart, we have now established, for the first time at the protein level, that both FAT/CD36 and H-FABP show a similar muscle tissue distribution (heart>soleus muscle> EDL muscle). Furthermore, FAT/CD36 and H-FABP are upregulated during development (heart) and after induction of experimental diabetes (skeletal muscles). These data are in line with the suggested protein-protein interaction between FAT/CD36 and $\mathrm{H}-\mathrm{FABP}^{(20)}$ and, therefore, further support the role for FAT/CD36 in the cellular uptake of long-chain fatty acids by muscle cells.

Table 4.1 FAT/CD36 and H-FABP protein content of adult rat muscles

\begin{tabular}{|l|c|c|c|c|}
\hline \multirow{2}{*}{} & \multicolumn{3}{|c|}{ Content (mg/g protein) } \\
\cline { 2 - 5 } & \multicolumn{2}{|c|}{ FAT/CD36 } & \multicolumn{2}{c|}{ H-FABP } \\
\hline Tissue & Control & Diabetic & Control & Diabetic \\
\hline Heart & $4.2 \pm 2.3$ & $11.0 \pm 5.7^{*}$ & $5.7 \pm 1.1$ & $7.4 \pm 2.4$ \\
\hline Soleus & $0.6 \pm 0.1$ & $1.4 \pm 0.5^{*}$ & $2.6 \pm 0.2$ & $4.8 \pm 0.8^{*}$ \\
\hline EDL & $0.3 \pm 0.1$ & $1.2 \pm 0.8^{*}$ & $0.5 \pm 0.1$ & $0.8 \pm 0.2^{*}$ \\
\hline Liver & $0.2 \pm 0.3$ & $0.2 \pm 0.1$ & $<0.1$ & $<0.1$ \\
\hline
\end{tabular}

The contents of FAT/CD36 and H-FABP were measured in non-perfused heart, skeletal muscles and liver obtained from adult control and streptozotocin-induced diabetic rats. Both FAT/CD36 and H-FABP values were determined via an ELISA specific for FAT/CD36 or H-FABP respectively. Data are expressed in $\mathrm{mg}$ per $\mathrm{g}$ of total protein and are means $\pm S D$ for six animals. *Significantly different from control $(p<0.05)$.

\subsubsection{Hibernation in ground squirrels}

\section{Background}

Ground squirrels do not eat during the hibernating season and their winter metabolism is based almost exclusively on lipids, slowly consuming the huge reserves of body fat that are laid down during late summer and early autumn feeding. ${ }^{(21)}$ Hence, all components of lipid catabolism including intertissue and intracellular transport, storage and release mechanisms, and oxidative pathways need to be optimized for the challenges of hibernation. FABPs are one of these components and play a role in the intracellular trafficking of non-esterified fatty acids.

\section{Materials and methods}

Fatty acid metabolism in hibernating squirrels was studied for the first time by investigating the H-FABP protein content in 4 groups of hearts $(n=13)$ from ground squirrels as obtained from the Department of Genetics, College of Agriculture and Life Sciences, Raleigh, North Carolina, USA. Each group contained hearts from squirrels sacrificed during different seasons and state of activity, i.e., summer active (August), hibernating (November), inter-bout arousal (December) and spring active (May). HFABP was measured with an ELISA as described in Chapter 3. Because no purified squirrel H-FABP was available, the percentage of cross-reactivity could not be determined. Therefore, data are expressed relative to human H-FABP. 
Results

In the active summer period (August), H-FABP in the heart was $1.32 \mathrm{mg} / \mathrm{g}$ protein, while during hibernation (November) and inter-bout arousal (December) values raised to 1.96 and $3.44 \mathrm{mg} / \mathrm{g}$ protein, respectively. In springtime, H-FABP dropped to $2.78 \mathrm{mg} / \mathrm{g}$ protein

\section{Discussion}

The up-regulation of FABP genes and proteins levels during hibernation ${ }^{(21)}$ and arousal is probably effective in increasing intracellular supplies and movement of long-chain fatty acids. This would help to support both basal lipid oxidation during torpor (sleep) and, perhaps more importantly, the high rates of lipid catabolism that fuel thermogenesis during arousal. Recently, upregulation of H-FABP in heart during hibernation has been reported in the little brown bat, confirming our observations in the squirrel. ${ }^{(22)}$

\subsubsection{H-FABP in salmon}

\section{Background}

In fish, Londraville et al. ${ }^{(23)}$ reported the isolation of H-FABP from the Antarctic icefish Chaenocephalus aceratus and showed that H-FABP data were similar to mammalian values, although they were derived from an organism that is distant from mammals in terms of phylogeny, body temperature, and physiology. ${ }^{(23)}$ They suggested that the FABP family is conserved not only in primary sequence, but also in its physiological properties. Because H-FABP expression is regulated via peroxisome proliferator-activated receptors, which are responsive to long-chain fatty acids, diets containing different fatty acids can influence H-FABP expression. ${ }^{(24)}$

The aim of this study was to determine the H-FABP concentration in control salmon. This knowledge will enable us to further study the effects of these diets on fatty acid metabolism in salmon breeding.

\section{Material and methods}

H-FABP was determined in control heart, red and white muscle from Atlantic Salmon $(n=6)$. Samples were obtained from Dr. Ann-Elise Jordal from the Norway Department of Fisheries, in cooperation with Nutreco, Netherlands. H-FABP was measured with an ELISA as described in Chapter 3. Because no purified salmon H-FABP was available, the percentage of cross-reactivity could not be determined. Therefore data were expressed relative to human $\mathrm{H}-\mathrm{FABP}$.

\section{Results}

In white glycolytic muscle, H-FABP content was $34 \pm 18 \mu \mathrm{g} / \mathrm{g}$ ww, while the more oxidative red muscle contained $193 \pm 39 \mu \mathrm{g} / \mathrm{g}$ ww. Heart muscle contained $141 \pm 29 \mu \mathrm{g} / \mathrm{g}$ Ww.

\section{Discussion}

In Atlantic salmon, we report for the first time H-FABP content in hearts and skeletal muscle. Strikingly, while glycolytic white muscle and aerobic red muscle showed comparable differences as in other vertebrates, the heart had a H-FABP content that is not higher than that of red muscle. This would suggest that fatty acids as energy source for fish heart are of less importance than in mammals. Further studies in fish fatty acid metabolism have to investigate this finding. 


\subsubsection{H-FABP as marker for skeletal muscle injury in racehorses}

\section{Background}

H-FABP is expressed both in heart and in skeletal muscles (see Chapter 7). ${ }^{(16)}$ Upon injury of either tissue, elevated H-FABP concentrations in plasma can be detected. This study was set up to investigate the use of H-FABP as plasma marker for skeletal muscle injury in racehorses.

\section{Materials and methods}

Plasma was obtained from 10 active racehorses from the Hong Kong Jockey Club, preand post-race (group A) and from 3 distinct horses suffering from stiffness after training (group B). In group A, glucose and lactate levels were measured to indicate the fitness of the horses. In group B, late plasma marker creatine kinase was measured to compare muscle injury with the early plasma marker H-FABP. Lactate, glucose and CK were measured by the local veterinarian hospital. Freshly dissected heart for H-FABP purification was obtained from the local slaughterhouse in Oensel, the Netherlands. Plasma H-FABP was measured with an ELISA as described in Chapter 3, using purified H-FABP as calibrator.

\section{Results}

\section{Comparison of pre- and post-race data}

In all horses of group A, there was a clear increase of plasma glucose, lactate and $\mathrm{H}-$ FABP levels after the race (Fig. 4.7). This accumulated level of glucose is the difference resulting from the glucose formation, driven by glycogen conversion after adrenaline action during the race, and consumption. The pre- and post-race difference in lactate level is a clear indicator for the oxygen supply of the muscle and therefore the fitness state of the horse. The more accumulated lactate, the less fit is the horse. For plasma H-FABP, an average increase of $300 \%$ could be measured after the physical stress of the race. This could indicate cellular damage as well as increased lymphatic washout.

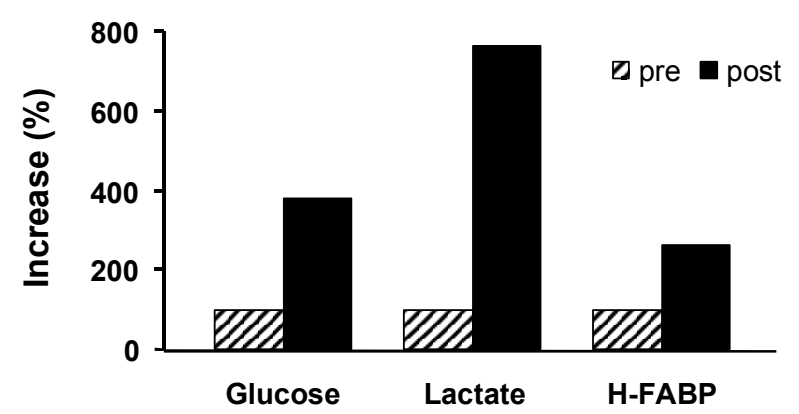

Figure 4.7 Plasma levels of glucose, lactate and H-FABP pre- and post-race horses $(n=10)$.

Clinical samples of individual horses taken over several days after muscle damage The horses of group B (Cassidy, Nugget and Jag) were investigated after getting stiff during the training. For Cassidy, CK values were high at the first day, indicating some muscle injury problem (Table 4.2). Lactate remained higher compared to normal, indicating poor fitness. For Nugget and Jag, CK values were quite low immediately after getting stiff. However, these levels increased several hours later at the same day. In all 3 
horses, the H-FABP plasma level directly after training was 15 to 45 times higher than normal, while in group A only 3 times elevated levels were found. However, in all 3 horses, H-FABP plasma levels returned to normal within 1 day. H-FABP proved to be a valuable earlier indicator than $\mathrm{CK}$ for muscle problems in 2 out of 3 horses as CK plasma levels were elevated almost 1 day later compared to H-FABP.

Table 4.2 Plasma levels of creatine kinase (CK), glucose, lactate and H-FABP of horse getting stiff after training.

\begin{tabular}{|c|c|c|c|c|}
\hline \multicolumn{5}{|c|}{ Cassidy } \\
\hline $\begin{array}{c}\text { Days after } \\
\text { training }\end{array}$ & CK & $\begin{array}{l}\text { Glucose } \\
\text { (mmol/L) }\end{array}$ & $\begin{array}{l}\text { Lactate } \\
\text { (mmol/L) }\end{array}$ & $\begin{array}{c}\text { H-FABP } \\
(\mu \mathrm{g} / \mathrm{L})\end{array}$ \\
\hline 1 & 11332 & 3.92 & 8.10 & 6.36 \\
\hline 2 & 391 & 5.51 & 2.36 & 0.20 \\
\hline 4 & 77 & 5.72 & 1.60 & 0.12 \\
\hline \multicolumn{5}{|c|}{ Nuggett } \\
\hline $\begin{array}{c}\text { Days after } \\
\text { training }\end{array}$ & CK & $\begin{array}{l}\text { Glucose } \\
\text { (mmol/L) }\end{array}$ & $\begin{array}{l}\text { Lactate } \\
\text { (mmol/L) }\end{array}$ & $\begin{array}{c}\text { H-FABP } \\
(\mu \mathrm{g} / \mathrm{L})\end{array}$ \\
\hline 1 & 3432 & 6.32 & 7.62 & 16.65 \\
\hline 1 & 14866 & 7.89 & 4.98 & 0.71 \\
\hline 2 & 1091 & 6.27 & 2.53 & 0.13 \\
\hline 4 & 211 & 6.46 & 2.25 & 0.09 \\
\hline \multicolumn{5}{|c|}{ Jag } \\
\hline $\begin{array}{c}\text { Days after } \\
\text { training }\end{array}$ & CK & $\begin{array}{l}\text { Glucose } \\
\text { ( } \mathrm{mmol} / \mathrm{L})\end{array}$ & $\begin{array}{l}\text { Lactate } \\
\text { (mmol/L) }\end{array}$ & $\begin{array}{c}\text { H-FABP } \\
(\mu \mathrm{g} / \mathrm{L})\end{array}$ \\
\hline 1 & 4415 & 4.46 & 7.14 & 15.83 \\
\hline 1 & 5259 & 6.38 & 5.20 & 0.26 \\
\hline 2 & 326 & 4.93 & 3.40 & 0.14 \\
\hline 4 & 113 & 5.71 & 2.01 & 0.10 \\
\hline
\end{tabular}

\section{Discussion}

The use of H-FABP as diagnostic marker for skeletal muscle injury in humans has previously been reported (see Chapter 7). ${ }^{(16)}$ In the present study H-FABP also turned out to be the earliest marker for muscle injury due to extensive exercise in race-horses. The established markers creatine kinase and lactate dehydrogenase appeared significantly later in plasma than H-FABP. The use of H-FABP in horse training programs could be beneficial for adjusting training and treatment of racehorses.

\subsubsection{H-FABP as marker for myocardial injury in mice}

\section{Background}

Ligation of the main left coronary artery in mice serves as a model for myocardial infarction. We tested whether plasma concentrations of H-FABP and/or cardiac troponin $\mathrm{T}$ (cTnT) discriminate between infarcted and sham-operated mice and whether this allowed a proper estimation of infarct size. ${ }^{(25)}$

\section{Materials and methods}

Mice were subjected to coronary artery ligation or sham surgery and release curves of $\mathrm{H}$ FABP and cTnT were determined by taking plasma samples at $0,4,24$ and $48 \mathrm{~h}$ after ligation. 
Plasma H-FABP was measured with an ELISA as described in Chapter 3, using recombinant mouse H-FABP as calibrator. Plasma cTnT was determined using the second-generation cTnT ELISA (Enzyme-test, Troponin T, Boehringer Mannheim Corp, Indianapolis, Ind).

\section{Results}

At $4 \mathrm{~h}$ after surgery the mean $( \pm \mathrm{SD}) \mathrm{H}-\mathrm{FABP}$ plasma concentration was $461 \pm 134 \mu \mathrm{g} / \mathrm{L}$ $(\mathrm{n}=10)$ in myocardial infarction and $185 \pm 51 \mu \mathrm{g} / \mathrm{L}(\mathrm{n}=6 ; p<0.001)$ in sham-operated mice (Fig. 4.8), while $24 \mathrm{~h}$ after surgery H-FABP levels had returned to normal levels in both groups. cTnT plasma concentrations increased up to $48 \mathrm{~h}$ after myocardial infarction to $13.5 \pm 6.2 \mu \mathrm{g} / \mathrm{L}(\mathrm{n}=6 ; p<0.001)$ compared with $0.031 \pm 0.063 \mu \mathrm{g} / \mathrm{L}(\mathrm{n}=7)$ in sham-operated mice. Linear regression analysis revealed a significant correlation between plasma $\mathrm{H}-$ FABP at $4 \mathrm{~h}$ and infarct size determined 7 days after surgery. Plasma cTnT did not correlate significantly with infarct size.
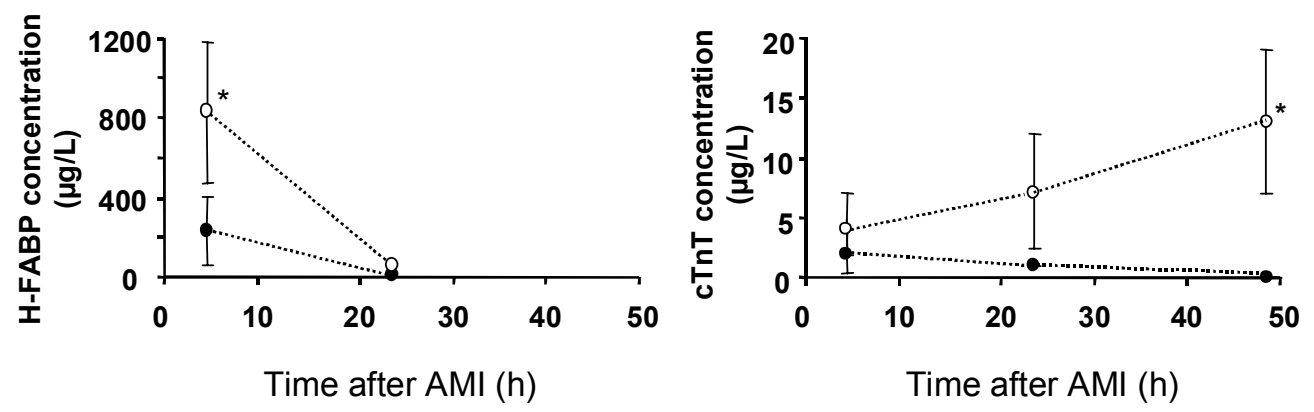

Figure 4.8 Plasma H-FABP (left panel) and cTnT (right panel) concentrations at 4,24 and $48 \mathrm{~h}$ after surgery. Mean $\pm S D$ of sham (solid circles, $n=9$ ) and MI (open circles, $n=9$ ), * $p<0.001$.

\section{Discussion}

As in humans ${ }^{(26)}$, H-FABP levels measured in mouse plasma increased earlier than plasma levels of cTnT after myocardial infarction. In the present study we also found $\mathrm{H}-$ FABP plasma levels at $4 \mathrm{~h}$ after infarct to be a suitable marker for the estimation of infarct size, while cTnT lacked this property. In conclusion, we can state that the plasma cTnT concentration at $48 \mathrm{~h}$ after infarction can be used to distinguish myocardial infarction from sham-operated mice, whereas H-FABP concentration at $4 \mathrm{~h}$ can be used for risk stratification of animals according to infarct size.

\subsection{General discussion}

Because the two monoclonal antibodies directed against human H-FABP specifically react with $\mathrm{H}-\mathrm{FABP}$ from other species with cross-reactivity ranging from 5 to $66 \%$, respective epitopes on this protein must be well conserved during evolution. The developed ELISA can, therefore, be used in a broad range of animal models to study either aspects of fatty acid metabolism or the release of H-FABP following tissue injury. When species-purified or recombinant H-FABP is available, real tissue or plasma values can be obtained. When no species standard is available, values should be expressed relative to human $\mathrm{H}-\mathrm{FABP}$. 


\subsection{References}

1. Glatz JFC, Van der Vusse GJ. Cellular fatty acid-binding proteins: their function and physiological signification. Prog Lipid Res 1996;3:243-82.

2. Glatz JFC, Storch J. Unravelling the significance of cellular fatty acid-binding proteins. Curr Opin Lipidol 2001;12:267-74.

3. Stremmel W, Strohmeyer G, Borchard F, Kochwa S, Berk PD. Isolation and partial characterization of a fatty acid-binding protein in rat liver plasma membranes. Proc Natl Acad Sci USA 1985;82:4-8.

4. Abumrad NA, El-Maghrabi MR, Amri EZ, Lopez E, Grimaldi PA. Cloning of a rat adipocyte membrane protein implicated in binding or transport of long-chain fatty acids that is induced during preadipocyte differentiation. Homology with human CD36. $J$ Biol Chem 1993;268:17665-8.

5. Schaap FG, van der Vusse GJ, Glatz JFC. Evolution of the family of intracellular lipid binding proteins in vertebrates. Mol Cell Biochem 2002;239:69-77.

6. Van Nieuwenhoven FA, Kleine AH, Wodzig KW, Hermens WT, Kragten HA, et al. Highyield two-step chromatographical procedure for purification of fatty acid-binding protein from human heart. J Chromatogr 1991;570:173-9.

7. Pelsers MMAL, Bishop CM, Butler PJ, Glatz JFC. Fatty acid-binding protein content of heart and skeletal muscles of the migratory barnacle goose during development. Am J Physiol 1999; 276: R637-43.

8. Schaap FG, Specht B, van der Vusse GJ, Borchers T, Glatz JF. One-step purification of rat heart-type fatty acid-binding protein expressed in Escherichia coli. J Chromatogr B Biomed Appl 1996;679:61-7.

9. Wodzig KWH, Pelsers MMAL, Van der Vusse GJ, Roos W, Glatz JFC. One-step enzymelinked immunosorbent assay (ELISA) for plasma fatty acid-binding protein. Ann Clin Biochem 1997;34:263-8.

10. Schmidt-Nielsen K. Animal Physiolog 1990, Cambridge, UK:Cambridge University Press.

11. Weber JM, Brichon G, Swingelstein G, McClelland G, Saucedo C, et al. Design of the oxygen and substrate pathways. IV. Partitioning energy provision from fatty acids. $J$ Exp Biol 1996;199:1667-74.

12. Jenni L, Jenni-Eiermann S. Fuel supply and metabolic constraints in migrating birds. J Avion Biol 1998;29:521-8.

13. Jenni-Eiermann S, Jenni L. High plasma triglyceride levels in small birds during migratory flights: a new pathway for fuel supply during endurance locomotion at very high massspecific metabolic rates? Physiol Zool 1992;65:112-23.

14. Bass NM. The cellular fatty acid-binding proteins: aspects of structure, regulation and function. Int Rev Cytol 1988;111:143-184.

15. Vork MM, Glatz JFC, Surtel DM, Knubben HJM, van der Vusse GJ. A sandwich enzyme linked immunosorbent assay for the determination of rat heart fatty acid-binding protein. Biochim. Biophys. Acta 1075: 199-205, 1991.

16. Van Nieuwenhoven FA, Kleine AH, Wodzig KWH, Hermens WT, Kragten HA, et al. Discrimination between myocardial and skeletal muscle injury by assessment of the plasma ratio of myoglobin over fatty acid-binding protein. Circulation 1995;92:2848-54.

17. Glatz JFC, Van Breda E, Keizer HA, de Jong YF, Lakey JR et al. Rat heart fatty acid-binding protein content is increased in experimental diabetes. Biochem Biophys Res Commun 1994; 199:639-46.

18. Luiken JJ, Koonen DP, Willems J, Zorzano A, Becker C, et al. Insulin stimulates long-chain fatty acid utilization by rat cardiac myocytes through cellular redistribution of FAT/CD36. Diabetes 2002;51:3113-9.

19. Pelsers MM, Lutgerink JT, Nieuwenhoven FA, Tandon NN, van der Vusse GJ, et al. A sensitive immunoassay for fatty acid translocase (CD36) using phage antibodies selected on 
cell trans-fectants: abundant presence of FAT/CD36 in cardiac and red skeletal muscle and upregulation in diabetes. Biochem J 1999;3:407-14.

20. Spitsberg VL, Matitashvili E, Gorewit RC. Association and coexpression of fatty acidbinding protein and glycoprotein CD36 in the bovine mammary gland. Eur J Biochem 1995;230:872-8.

21. Hittel D, Storey KB. Differential expression of adipose- and heart-type fatty acid binding proteins in hibernating ground squirrels. Biochim Biophys Acta 2001;30:238-43.

22. Eddy SF, Storey KB. Up-regulation of fatty acid-binding proteins during hibernation in the little brown bat, Myotis Lucifugus. Biochim Biophys Acta 2004;1676:63-70.

23. Londraville RL, Sidell BD. Purification and characterization of fatty acid-binding protein from aerobic muscle of the Antarctic icefish Chaenocephalus aceratus. $J$ Exp Zool 1995;273:190-203.

24. Gilde AJ, Van Bilsen M. Peroxisome proliferator-activated receptors (PPARs): regulators of gene expression in heart and skeletal muscle. Acta Physiol Scand 2003;175:425-34.

25. Aartsen WM, Pelsers MMAL, Hermens WT, Glatz JFC, Daemen MJAP, et al. Heart fatty acid-binding protein and cardiac troponin $\mathrm{T}$ plasma concentrations as markers for myocardial infarction after coronary ligation in mice. Pfluglers Arch 2000;439:416-22.

26. Glatz JFC, van der Voort D, Hermens WT. Fatty acid-binding protein as the earliest available plasma marker of acute myocardial injury. J Clin Lig Ass 2002;25:167-77. 


\section{Influence of age, sex and day-to-day and within-day biological variation on plasma concentrations of heart-type fatty acid- binding protein and myoglobin in healthy subjects}

Part of this chapter is published:

Pelsers MMAL, Chapelle JP, Knapen M, Vermeer C, Muijtjens, et al. Influence of age, sex and day-to-day and within-day variation on plasma concentrations of fatty acidbinding protein and myoglobin in healthy subjects. Clin Chem 1999;45:441-3. 


\subsection{Abstract}

In order to establish a clinical reference range for H-FABP and Myoglobin $(\mathrm{Mb})$, the influence of age, sex and biological variation on normal plasma H-FABP and $\mathrm{Mb}$ concentrations in healthy individuals needs to be extensively evaluated. For the influence of age and sex, plasma samples were obtained from 312 donors visiting the blood bank of Liège, Belgium. For the study of within-person biological variation, plasma samples were obtained from 6 young and apparently healthy volunteers recruited from the student population of Maastricht University. H-FABP was measured with the sensitive noncompetitive sandwich-type ELISA as described in Chapter 3. The median and 95\% confidence interval plasma concentrations of $\mathrm{H}-\mathrm{FABP}$ and $\mathrm{Mb}$ were $1.5 \mu \mathrm{g} / \mathrm{L}$ (0.7-5.9 $\mu \mathrm{g} / \mathrm{l})$ and $27 \mu \mathrm{g} / \mathrm{L}(10.3-56.3 \mu \mathrm{g} / \mathrm{L})$ respectively, and were significantly lower in women than in men $(p<0.005)$. Both markers also showed an increase in the health-related plasma concentration during aging, but the effect of aging was more prominent in the plasma concentration of H-FABP $(p<0.001)$ than $\mathrm{Mb}(p<0.01)$. For the within-day biological variation, a significant increase was seen for H-FABP plasma concentration from daytime $(0.8 \mu \mathrm{g} / \mathrm{L})$ to evening $(0.9 \mu \mathrm{g} / \mathrm{L})$ to night $(1.1 \mu \mathrm{g} / \mathrm{L})$. The same trend was seen for $\mathrm{Mb}$ but this did not reach statistical significance.

In conclusion, time of day, age and sex do influence the reference value of both H-FABP and $\mathrm{Mb}$. Therefore, we suggest an upper reference value of $6 \mu \mathrm{g} / \mathrm{L}$ for $\mathrm{H}-\mathrm{FABP}$ and 60 $\mu \mathrm{g} / \mathrm{L}$ for $\mathrm{Mb}$.

\subsection{Introduction}

Both heart-type FABP (H-FABP) and Myoglobin (Mb), increase significantly within 1 to $3 \mathrm{~h}$ after onset of symptoms of acute myocardial infarction (AMI) and return to healthrelated values within 12 to $24 \mathrm{~h}^{(1)}$ For the early assessment or exclusion of AMI, HFABP performs better than $\mathrm{Mb}^{(2,3)}$ Although $\mathrm{H}-\mathrm{FABP}$, like $\mathrm{Mb}$, is also found in skeletal muscle, the distinct ratio of the contents of Mb over H-FABP in heart (ratio 2 to 5) and skeletal muscle (ratio 20 to 70 ) allows the discrimination between myocardial and skeletal muscle injury. ${ }^{(4)}$

For the assessment of clinical reference values, it is important to know the possible influence of biological variations such as age, sex, and day-to-day and within-day fluctuations. ${ }^{(5)}$ However, for H-FABP such data are not complete, although variation in normal values due to age and sex have been reported before (see Chapter 3). The aim of the present study was to establish these parameters for H-FABP first in a large group of volunteers of different ages. Myoglobin was also measured to delineate possible effects of age and sex on the ratio of the plasma concentrations of Mb over H-FABP. We also studied day-to-day and within-day biologic variation (within-person) for both H-FABP and $\mathrm{Mb}$ concentrations in another group of volunteers.

\subsection{Material and methods}

\subsubsection{Plasma samples}

For the first substudy, plasma samples were taken from 312 donors (110 women and 202 men; ages, 21 to 70 years) visiting the blood bank of Liège, Belgium. EDTA was added to the samples to prevent clotting. For the study of within-person biologic variation, 
plasma samples were obtained from young and apparently healthy volunteers (six men and six women, aged 19 to 27 years), recruited from the student population of Maastricht University. Samples were obtained at the following time points: on day 1, at 09.30, 11.00, $14.00,17.00,20.00$, and $23.00 \mathrm{~h}$; on day 2, at $03.00,07.00,09.30 \mathrm{~h}$; and on days 8, 15, 22, 29, and 57 at $09.30 \mathrm{~h}$. Citrate was added to prevent clotting, and samples were immediately aliquoted and frozen at $-80^{\circ} \mathrm{C}$ until further analyses. The study was approved by the medical ethics committee of the Academic Hospital Maastricht, and all subjects gave informed consent.

\subsubsection{Assays}

H-FABP was measured with a sensitive noncompetitive sandwich-type ELISA as described in Chapter $3^{(6)}$, using recombinant human H-FABP as the calibrator. ${ }^{(7)} \mathrm{Mb}$ was measured with a turbidimetric immunoassay (Unimate $3 \mathrm{Mb}$; Roche Diagnostic Systems) on a Cobas Mira plus analyzer (Roche). The inter- and intra-assay analytical imprecision (CV) was $<11 \%$ for $\mathrm{H}-\mathrm{FABP}^{(6)}$ and $<10 \%$ for $\mathrm{Mb}$ (Unimate 3 performance data; Roche). Both assays showed no interference from either citrate or EDTA (data not shown).

\subsubsection{Statistics}

BMDP Statistical software was used for statistical analysis. All data are presented as medians, with 2.5 and 97.5 percentiles in parentheses. Samples with values below the detection limit of $0.3 \mu \mathrm{g} / \mathrm{L}$ FABP or $7.5 \mu \mathrm{g} / \mathrm{L} \mathrm{Mb}$ were assigned the detection limit.

\subsection{Results}

The median plasma concentrations of $\mathrm{H}-\mathrm{FABP}$ and $\mathrm{Mb}$ in the first substudy $(\mathrm{n}=312)$ were $1.5 \mu \mathrm{g} / \mathrm{L}(0.7-5.9 \mu \mathrm{g} / \mathrm{L})$ and $27 \mu \mathrm{g} / \mathrm{L}(10.3-56.3 \mu \mathrm{g} / \mathrm{L})$, respectively. The median ratio of the plasma concentrations of $\mathrm{Mb}$ over H-FABP was 15.3 (5.0-39.7). Plasma concentrations of both cardiac markers showed a sex dependency. Plasma H-FABP $(p<0.005$; Mann-Whitney test $)$ and $\mathrm{Mb}(p<0.0001)$ values were lower in women than in men (Fig. 5.1). The ratio of Mb over H-FABP showed no significant difference between sexes. Both cardiac markers showed an increase in the health-related plasma concentration during aging (Fig. 5.1). The effect of aging was more prominent in the plasma concentration of H-FABP $(p<0.0001$; regression analysis) than $\mathrm{Mb}(p<0.01)$. As a result, the ratio of $\mathrm{Mb}$ over $\mathrm{H}-\mathrm{FABP}$ was also age-dependent $(p<0.001)$.

The day-to-day variation in plasma concentrations of $\mathrm{H}-\mathrm{FABP}$ and $\mathrm{Mb}$, expressed as mean CV (within-person) of seven time points (days 1, 2, 8, 15, 22, 29, and 57) of all 12 subjects and calculated as $\mathrm{CV}^{2}$ within-person $=\mathrm{CV}^{2}$ total $-\mathrm{CV}^{2}$ analytical imprecision ${ }^{(5)}$ was $14 \%$ for H-FABP and $18 \%$ for Mb. For analysis of within-day variation of H-FABP and $\mathrm{Mb}$, three time blocks were used: daytime as the most active period (09.30-17.00), evening as a more relaxed period (17.00-03.00), and night as the resting period (03.0009.30). For plasma H-FABP, a significant increase was seen $(p<0.005$; BMDP Statistical Software, program $2 \mathrm{~V})$ from daytime $(0.8 \mu \mathrm{g} / \mathrm{L})$ to evening $(0.9 \mu \mathrm{g} / \mathrm{L})$ to night $(1.1$ $\mu \mathrm{g} / \mathrm{L})$. For $\mathrm{Mb}$, a similar trend was found from daytime $(20.9 \mu \mathrm{g} / \mathrm{L})$ to evening $(22.6$ $\mu \mathrm{g} / \mathrm{L})$ to night $(23.1 \mu \mathrm{g} / \mathrm{L})$; however, this did not reach statistical significance. The overall values for men [H-FABP, $1.2 \mu \mathrm{g} / \mathrm{L}(0.6-1.6 \mu \mathrm{g} / \mathrm{L}) ; \mathrm{Mb}, 25 \mu \mathrm{g} / \mathrm{L}(22-29 \mu \mathrm{g} / \mathrm{L})]$ and women [H-FABP, $0.7 \mu \mathrm{g} / \mathrm{L}(0.4-1.2 \mu \mathrm{g} / \mathrm{L}) ; \mathrm{Mb}, 20 \mu \mathrm{g} / \mathrm{L}(15-22 \mu \mathrm{g} / \mathrm{L})]$ confirm the data of the first substudy (age group, 21 to 30 years). 

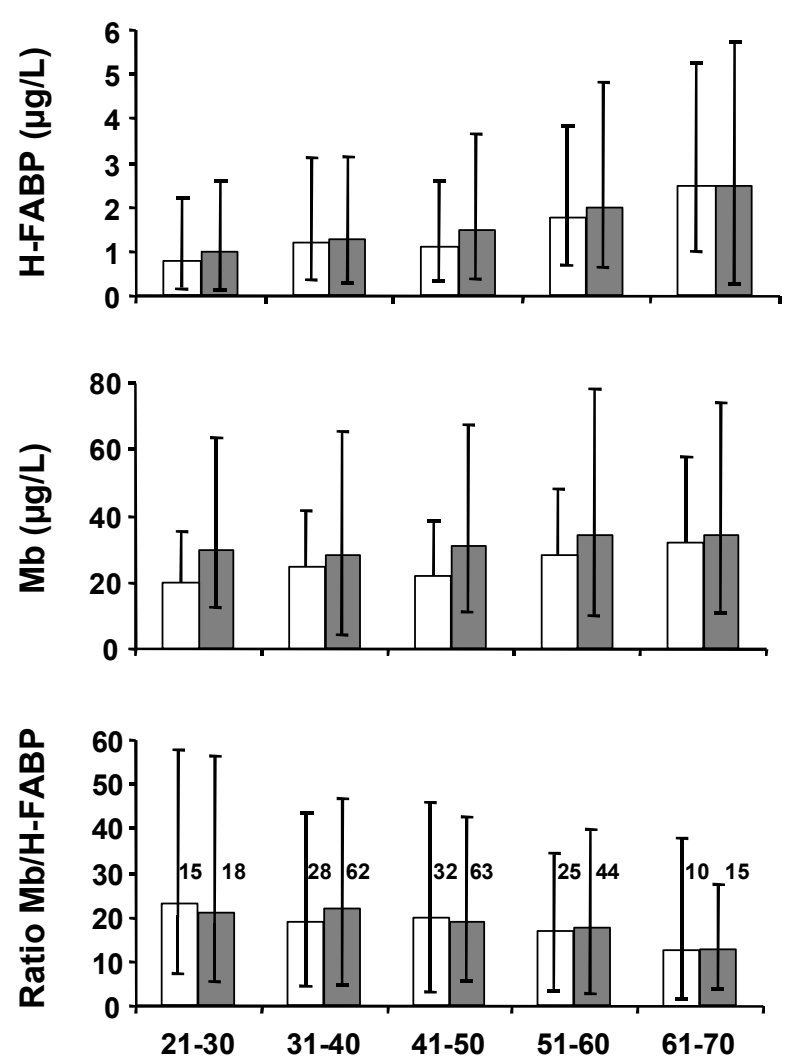

Figure 5.1 Median plasma concentrations (2.5 and 97.5 percentiles) of H-FABP (upper panel), $\mathrm{Mb}$ (middle panel), and the plasma ratio of $\mathrm{Mb}$ over H-FABP (lower panel) in apparently healthy men (black bars) and women (white bars) of different age groups. Numbers above bars refer to the number of subjects studied.

\section{Age (years)}

\subsection{Discussion}

The measured median plasma H-FABP $(1.5 \mu \mathrm{g} / \mathrm{L})$ and $\mathrm{Mb}(27 \mu \mathrm{g} / \mathrm{L})$ concentrations of healthy subjects are similar to previously published values of $1.6 \mu \mathrm{g} / \mathrm{L}$ for H-FABP and $33 \mu \mathrm{g} / \mathrm{L}$ for $\mathrm{Mb}^{(1,6)}$, as are the differences in myoglobin plasma values between men and women. ${ }^{(8,9)}$ The observed increases of the H-FABP and Mb plasma concentrations with age, especially after 50 years, are most likely explained by the decrease in renal function in elderly people, which in the case of $\mathrm{Mb}$ may be partly counterbalanced by diminishing skeletal muscle mass, especially in men. ${ }^{(10)}$ Both cardiac markers show differences between men and women, which might be explained by the fact that men have a relatively larger muscle mass than women.

The within-day variations found for H-FABP may be related to the reported increased glomerular filtration rate during the day ${ }^{(11)}$ but this explanation is not confirmed by a significant within-day variation of $\mathrm{Mb}$. A limitation of this substudy is that observations were made for subjects 19 to 27 years of age, whereas most acute coronary syndromes appear in older persons.

In conclusion, this study shows that when using H-FABP and (or) $\mathrm{Mb}$ as plasma markers for the diagnosis of AMI, the time of day is of minor relevance; age and sex, however, are more important because these will influence the upper reference values of both these markers. In addition, caution should be taken when using the Mb over $\mathrm{H}-\mathrm{FABP}$ ratio to discriminate cardiac from skeletal muscle injury, especially for patients $>50$ years of age. 
For clinical reference, we suggest a value of $6 \mu \mathrm{g} / \mathrm{L}$ H-FABP as cut-off for myocardial injury.

\subsection{References}

1. Glatz JFC, Van der Vusse GJ, Simoons ML, Kragten JA, Van Dieijen-Visser MP, et al. Fatty acid-binding protein and the early detection of acute myocardial infarction. Clin Chim Acta 1998;242:87-92.

2. Ishii J, Wang JH, Naruse H, Taga S, Kinoshita M, et al. Serum concentrations of myoglobin vs heart-type cytoplasmic fatty acid-binding protein in early detection of acute myocardial infarction. Clin Chem 1997;43:1372-8.

3. Glatz JFC, Haastrup B, Hermens WT, de Zwaan C, Barker J, et al. Fatty acid-binding protein and the early detection of acute myocardial infarction: the EUROCARDI multicenter trial Circulation 1997;96:215.

4. Van Nieuwenhoven FA, Kleine AH, Wodzig KWH, Hermens WT, Kragten JA, et al. Discrimination between myocardial and skeletal muscle injury by assessment of the plasma ratio of myoglobin over fatty acid-binding protein. Circulation 1995;92:2548-54.

5. Ross SM, Fraser CG. Biological variation of cardiac markers: analytical and clinical considerations. Ann Clin Biochem 1998;35:80-4.

6. Wodzig KWH, Pelsers MMAL, Van der Vusse GJ, Roos W, Glatz JFC. One-step enzymelinked immunosorbent assay (ELISA) for plasma fatty acid-binding protein. Ann Clin Biochem 1997;34:263-8.

7. Schreiber A, Specht B, Pelsers MMAL, Glatz JFC, Börchers T, et al. Recombinant heart type fatty acid-binding protein as standard in immunochemical assays. Clin Chem Lab Med 1998;36:283-8.

8. Chapelle JP, Lemache K, El Allaf M, El Allaf D, Piérard L. Fast determination of myoglobin in serum using a new radial partition immunoassay. Clin Biochem 1994;27:423-8.

9. Chen IW, David R, Maxon HR, Sperling M, Stein EA. Age-, sex-, and race-related differences in myoglobin concentrations in the serum of healthy persons. Clin Chem 1980;26:1864-8.

10. Górski J, Hermens WT, Borawski J, Mysliwiec M, Glatz JFC. Increased fatty acid-binding protein concentration in plasma of patients with chronic renal failure. Clin Chem 1997;43:193-5.

11. Minors DS, Waterhouse JM. Circadian rhythms and the human, Bristol, UK. Wright PSG 1981;68-94. 
Chapter 5 
Plasma fatty acid-binding protein outperforms troponin $\mathbf{T}$ as a sensitive marker for minor myocardial injury in chronic heart failure and unstable angina

Part of this chapter is published:

Pelsers MMAL, Bakker J, Pinto Y, van Dieijen-Visser MP, Hermens WT, et al. Plasma fatty acid-binding protein outperforms TnT as a sensitive marker of myocardial injury in heart failure. Clin Chem Lab Med 2003;41:S11.6 


\subsection{Abstract}

Recent studies indicate that progressive deterioration of ventricular function in patients with chronic heart failure (CHF) is associated with ongoing myocardial injury. However, many patients with CHF or unstable angina pectoris (UAP) are not diagnosed and treated as having minor myocardial injury, because the currently used biochemical plasma markers lack sufficient sensitivity. In this study we compared heart-type fatty acidbinding protein (H-FABP) and cardiac Troponin $\mathrm{T}$ (cTnT) as markers for minor myocardial injury during CHF and UAP. Plasma samples were obtained at admission from 62 consecutive patients with CHF (NYHA class III or IV) and 23 patients with UAP. All CHF patients had elevated $(\geq 62 \mathrm{pmol} / \mathrm{L})$ plasma concentrations of NT-Brain Natriuretic Peptide (NT-proBNP). In both groups no skeletal muscle injury was present, as evidenced from a plasma myoglobin/H-FABP ratio $<15$. Kidney malfunction was determined by plasma creatinine levels $>120 \mu \mathrm{M}$. Patients were subdivided into four groups according to plasma concentrations of H-FABP and cTnT. In the CHF group, plasma cTnT was elevated $(>0.02 \mu \mathrm{g} / \mathrm{L})$ in 28 patients. H-FABP however was elevated $(>6 \mu \mathrm{g} / \mathrm{L})$ in 42 patients. Interestingly, only 3 patients had a normal H-FABP level together with an elevated cTnT level, while 17 patients $(29 \%)$ showed increased plasma H-FABP, despite a normal plasma cTnT concentration. In the UAP group, 6 patients $(26 \%)$ had elevated H-FABP levels with normal cTnT levels. Kidney function did not influence the relative differences between H-FABP and cTnT for detection of myocardial injury. H-FABP had a significantly better negative predictive value than cTnT. Patients with a plasma H-FABP level below the reference value had $19 \%$ chance of a recurrent cardiac event within 90 days, while patients with a plasma cTnT below the reference value had a $43 \%$ chance of a recurrent cardiac event. These data suggest that $(i)$ minor myocardial cell necrosis is detectable in a significant proportion of patients with $\mathrm{CHF}$, (ii) $\mathrm{H}-\mathrm{FABP}$ is a more sensitive marker for detection of minor myocardial injury than cTnT, (iii) H-FABP is a significant better prognostic marker than cTnT.

\subsection{Introduction}

In the last decade, cardiac specific Troponins (cTnT and cTnI) have emerged as important parameters for the diagnosis and treatment of patients with suspected myocardial injury. ${ }^{(1)}$ Together with the currently used markers myoglobin $(\mathrm{Mb})$ and creatine-kinase MB (CK-MB) these sensitive and specific cardiac markers are essential as new therapeutic strategies have called for earlier and more appropriate diagnosis to exclude low-risk patients who can be sent home safely. ${ }^{(2)}$ Although acute myocardial infarctions account for most myocardial injuries, elevated plasma concentrations of cTnT have also been shown in a marked proportion of patients with CHF, indicating that progressive deterioration of ventricular function in CHF patients is associated with ongoing minor myocardial injury and worse prognosis. ${ }^{(3,4)}$ In addition, in patients with idiopathic dilated cardiomyopathy ${ }^{(5)}$ and with $\mathrm{UAP}^{(6,7)}$ elevated levels of cTnT indicate minor necrosis and increased risk.

Nowadays CHF, which can be subdivided into two entities, namely systolic (difficulty emptying the left ventricle) and diastolic (inability to fill and relax the left ventricle) dysfunction, has become a major cardiovascular disease with a poor prognosis and an increased prevalence during aging. Although many cardiac disorders can lead to CHF (like previous myocardial infarction, myocarditis, cardiomyopathy), coronary artery 
disease and hypertension are currently the most common causes. Stretch of the left ventricle by increased ventricular wall tension and volume overload leads mainly to elevated secretion of the B-type natriuretic peptide (BNP). ${ }^{(8,9)} \mathrm{BNP}$ and the splice product NT-proBNP have shown to accurately reflect heart failure severity as classified by the New York Heart Association (NYHA). ${ }^{(10)}$ However, minor necrosis of cardiomyocytes is very often not detected by a coronary angiogram. Therefore, cytoplasmic and myofibrillar proteins are evaluated as sensitive markers for minor myocardial injury in patients without acute coronary syndrome (ACS) like UAP and CHF. These markers are not only useful for diagnosis of myocardial injury, but can also serve as prognostic markers for the prediction of future cardiac events. ${ }^{(4,6,7)}$

The small (15 kD) cytoplasmic H-FABP was compared with cTnT and showed similar prognostic values. ${ }^{(4)}$ H-FABP is predominantly expressed in the heart, but to a much lower extent also in skeletal muscle, distal tubulus cells of the kidney, small intestine and the brain. ${ }^{(1)}$ The release of H-FABP into the bloodstream after tissue injury is relatively rapid and comparable with that of myoglobin (see Chapter 2). However, due to the relatively low plasma value in healthy individuals and the high tissue content, H-FABP is more sensitive than either myoglobin or $\mathrm{cTnT}$ and, therefore, a better marker for minor myocardial injury. ${ }^{(12-14)}$

In order to improve sensitivity and specificity of detecting minor myocardial injury, we compared plasma levels of H-FABP and cTnT in patients with CHF or UAP. As both proteins are cleared by the kidney ${ }^{(15,16)}$, creatinine levels were determined to study the influence of renal dysfunction.

\subsection{Materials and Methods}

\subsubsection{Subjects}

Chronic heart failure: we studied 62 consecutive patients (40 men and 22 women, mean age \pm SD: $75,1 \pm 11,1$ years) with suspected chronic heart failure (NYHA class III or IV), who were admitted to the University Hospital Maastricht between March 2003 and May 2003. Serum samples were obtained upon admission. NT-proBNP was measured as indication of the degree of CHF. ${ }^{(9)}$.

Unstable Angina Pectoris: we studied 23 patients with suspected unstable angina pectoris (17 men and 6 women, mean age \pm SD: $68.6 \pm 9.9$ years), who were admitted to the University Hospital Maastricht during the above-mentioned period. Serum samples were obtained upon admission.

In both groups, patients with skeletal muscle injury (plasma myoglobin/FABP ratio 20 to 70) or active myocardial ischemia (discharge diagnosis) were excluded. Creatinine was measured to study the influence of renal function. The study was approved by the local medical ethical committee.

\subsubsection{Measurements}

H-FABP was measured with a commercially available sandwich ELISA obtained from HyCult biotechnology (Uden, the Netherlands) as described in Chapter 3. Using standards of 2 and $12 \mu \mathrm{g} / \mathrm{L}$, the intra- and interassay variations were $5 \%$ and $<11 \%$, 
respectively. The detection limit of the assay was $0.3 \mu \mathrm{g} / \mathrm{L}$. No cross-reactivity $(<0.01 \%)$ of the used monoclonal antibodies with other types of FABP was detected. ${ }^{(17)}$

cTnT, NT-proBNP, and myoglobin were measured with an electro-chemiluminescence immuno assay (ECLIA method, Elecsys ${ }^{\circledR}$ ). Creatinine was analysed on a Beckman Synchron CX-7 system (Beckman Instruments, Mijdrecht, The Netherlands). Quality control was performed with a control serum from the manufacturer, and intra- and interassay imprecisions were 1.3 and $1.9 \%$, respectively.

\subsubsection{Analysis}

The cut-off value for $\mathrm{H}-\mathrm{FABP}$ was $6 \mu \mathrm{g} / \mathrm{L}$ as the normal value in plasma of healthy donors $(\mathrm{n}=310)$ ranges from 0.70 to $5.88 \mu \mathrm{g} / \mathrm{L}(2.5-97.5$ percentile) and is influenced by age, sex and circadian rhythm (see Chapter 5). ${ }^{(18)}$ For cTnT, the currently used cut-off value for a myocardial infarct is $0.1 \mu \mathrm{g} / \mathrm{L}$, although $0.05 \mu \mathrm{g} / \mathrm{L}$ is being proposed since new and more sensitive immunoassays are developed. The detection limit of the immunoassay kit from Roche Diagnostics is $0.0123 \mu \mathrm{g} / \mathrm{L} .{ }^{(19)}$ Setsuta et al. ${ }^{(4)}$ have set the cut-off value for detection of minor myocardial injury by cTnT at $0.02 \mu \mathrm{g} / \mathrm{L}$ as 45 asymptomatic subjects with normal ECG, echocardiography and chest x-ray all showed cTnT levels $<0.02 \mu \mathrm{g} / \mathrm{L}$. The effect of renal function was analyzed at creatinine plasma levels of 120,150 and $190 \mu \mathrm{M}$.

\subsection{Results}

In the CHF group, we excluded 2 patients with acute myocardial ischemia and 2 patients with no proper diagnosis. In both groups no skeletal muscle injury (plasma myoglobin/FABP ratio $20-70)^{(20)}$ was observed.

\section{CHF}

CHF patients could be subdivided into four groups according to the plasma concentrations of H-FABP and cTnT (Table 6.1) In the total CHF group, median plasma cTnT level was $0.02 \mu \mathrm{g} / \mathrm{L}(2.5-97.5$ percentiles $0.01-1.41 \mu \mathrm{g} / \mathrm{L})$ while 28 patients had elevated $(>0.02 \mu \mathrm{g} / \mathrm{L})$ plasma cTnT levels (Table 6.1A). H-FABP was elevated ( $>6 \mu \mathrm{g} / \mathrm{L})$ in 42 patients; median level in the total CHF group was $11.0 \mu \mathrm{g} / \mathrm{L}(2.5-97.5$ percentiles 3.2-47.1 $\mu \mathrm{g} / \mathrm{L}$ ). As shown in Table 6.1, 38 patients had an elevated cTnT as well as an elevated H-FABP or a normal cTnT as well as a normal H-FABP. Only 3 patients had a normal H-FABP level together with an elevated cTnT level, while 17 patients $(29 \%)$ showed increased plasma H-FABP despite a normal plasma cTnT concentration.

\section{$U A P$}

The same subdivision as mentioned above could be made in the UAP group (Table 6.1). Median plasma cTnT was $0.01 \mu \mathrm{g} / \mathrm{L}(2.5-97.5$ percentiles $0.008-0.75 \mu \mathrm{g} / \mathrm{L})$ while 11 patients had elevated $(>0.02 \mu \mathrm{g} / \mathrm{L})$ plasma cTnT levels (Table 6.1B). H-FABP was elevated $(>6 \mu \mathrm{g} / \mathrm{L})$ in 15 patients; median level in the total UAP group was $7.5 \mu \mathrm{g} / \mathrm{L}(2.5-$ 97.5 percentiles $1.61-45.53 \mu \mathrm{g} / \mathrm{L}$ ). Only 2 patients had a normal H-FABP level together with an elevated cTnT level, while 6 patients $(26 \%)$ showed increased plasma H-FABP despite a normal plasma cTnT concentration. Interestingly, 13 UAP patients had elevated ( $\geq 62 \mathrm{pmol} / \mathrm{L}$ ) BNP levels. 
Table 6.1 Distribution of hospitalized CHF and UAP patients according to normal or elevated plasma FABP $(>6 \mu \mathrm{g} / \mathrm{L})$ and cTnT concentrations $(>0.02 \mu \mathrm{g} / \mathrm{L})$.

\begin{tabular}{|l|c|c|}
\hline$A$ & $\mathbf{c T n T}+(\mathbf{n}=\mathbf{2 8})$ & $\mathbf{c T n T}-(\mathbf{n}=\mathbf{3 0})$ \\
\hline FABP $+(\mathbf{n = 4 2})$ & 25 & 17 \\
\hline FABP $-(\mathbf{n = 1 6})$ & 3 & 13 \\
\hline
\end{tabular}

\begin{tabular}{|l|c|c|}
\hline$B$ & cTnT + $(n=11)$ & cTnT $-(n=12)$ \\
\hline FABP $+(n=15)$ & 9 & 6 \\
\hline FABP $-(n=8)$ & 2 & 6 \\
\hline
\end{tabular}

$\operatorname{CHF}(A, n=58), \operatorname{UAP}(B, n=23)$

Table 6.2 Influence of renal function on the distribution of hospitalized CHF patients according to normal or elevated plasma FABP $(>6 \mu \mathrm{g} / \mathrm{L})$ and cTnT concentrations $(>0.02 \mu \mathrm{g} / \mathrm{L})$.

\begin{tabular}{|c|l|l|l|}
\hline $\begin{array}{c}\text { Creatinine cut off value } \\
(\boldsymbol{\mu} \mathrm{mol} / \mathrm{L})\end{array}$ & \multicolumn{3}{|c|}{ Number of patients } \\
\cline { 2 - 4 } & & TnT + & TnT - \\
\hline \multirow{2}{*}{120} & FABP + & 7 & 14 \\
\cline { 2 - 4 } & FABP - & 3 & 9 \\
\hline \multirow{2}{*}{150} & FABP + & 13 & 16 \\
\cline { 2 - 4 } & FABP - & 3 & 10 \\
\hline \multirow{2}{*}{190} & FABP + & 15 & 18 \\
\cline { 2 - 4 } & FABP - & 3 & 12 \\
\hline
\end{tabular}

CHF ( $n=58)$. Patients with creatinine $>$ cut-off value were not taken into account.

\section{Renal function in $\mathrm{CHF}$}

Although creatinine levels above $120 \mu \mathrm{M}$ indicated that 25 out of 58 patients showed diminished creatinine clearance, no difference between H-FABP and cTnT was observed with respect to the sensitivity of detecting myocardial injury at plasma creatinine levels of $120 \mu \mathrm{M}, 150 \mu \mathrm{M}$ and $190 \mu \mathrm{M}$ (Table 6.2).

\section{Prognostic value in $\mathrm{CHF}$}

Table 6.3 shows that elevated plasma levels of both H-FABP and cTnT have no power to discriminate the positive predictive value ( $\mathrm{PPV}=$ true positives/(true + false positives)) of recurrent events. PPV for H-FABP and cTnT is $45.4 \%$ and $39.3 \%$ respectively. However, when both markers are below reference value, the negative predictive value (NPV= true negatives/ (true+false negatives)) of recurrent cardiac events for H-FABP and cTnT is $81.3 \%$ and $56.7 \%$ respectively. So when plasma H-FABP level is below the clinical reference value of $6 \mu \mathrm{g} / \mathrm{L}$, only $18.7 \%$ of the patients have a recurrent cardiac event, while when cTnT is below the reference value $43.3 \%$ of the patients have a recurrent event.

Table 6.3 Recurrent cardiac event rate of CHF patients within 90 days after hospital discharge.

\begin{tabular}{|l|c|}
\hline & $\begin{array}{c}\text { Number of } \\
\text { patients }\end{array}$ \\
\hline $\mathrm{FABP}>6 \mu \mathrm{g} / \mathrm{L}$ and recurrent event within 90 days & 19 \\
\hline $\mathrm{FABP}>6 \mu \mathrm{g} / \mathrm{L}$ and no recurrent event within 90 days & 23 \\
\hline $\mathrm{FABP}<6 \mu \mathrm{g} / \mathrm{L}$ and recurrent event within 90 days & 3 \\
\hline $\mathrm{FABP}<6 \mu \mathrm{g} / \mathrm{L}$ and no recurrent event within 90 days & 13 \\
\hline $\mathrm{cTnT}>0.02 \mu \mathrm{g} / \mathrm{L}$ and recurrent event within 90 & 11 \\
\hline $\mathrm{cTnT}>0.02 \mu \mathrm{g} / \mathrm{L}$ and no recurrent event within 90 & 17 \\
\hline $\mathrm{cTnT}<0.02 \mu \mathrm{g} / \mathrm{L}$ and recurrent event within 90 & 11 \\
\hline $\mathrm{cTnT}<0.02 \mu \mathrm{g} / \mathrm{L}$ and no recurrent event within 90 & 19 \\
\hline
\end{tabular}




\subsection{Discussion}

Troponins have become established markers for the detection of myocardial injury. ${ }^{(21)}$ However, congestive heart failure and unstable angina pectoris are cardiovascular diseases with minor myocardial injury due to ventricular remodeling, changes in the extracellular matrix, disturbances in calcium regulation, and necrosis or apoptosis of cardiomyocytes. ${ }^{(22-24)}$ Comparable to observations by Setsuta et al. ${ }^{(4)}$, we detected elevated cTnT levels only in $48.3 \%$ CHF patients (28 out of 58). In contrast, H-FABP was found to detect ongoing minor myocardial injury in $72.4 \%$ CHF patients (42 out of 58), indicating that H-FABP is a more sensitive marker for minor cardiomyocyte necrosis than cTnT. These data are confirmed in the patient group with unstable angina pectoris where H-FABP detects minor myocardial injury in $25 \%$ more patients when compared to cTnT. Myoglobin was measured in both patient groups in order to exclude elevated levels of H-FABP due to skeletal muscle injury as reported previously by Van Nieuwenhoven et al. ${ }^{(20)}$ and suggested by Setsuta et al. ${ }^{(4)}$ The plasma myoglobin/H-FABP ratio indicated no skeletal muscle injury (ratio $<15$ ), and therefore elevated H-FABP levels must be due to cardiomyocyte injury. In $3 \mathrm{CHF}$ and 2 UAP patients, cTnT was elevated, while H-FABP was not. These patients probably suffered from a small myocardial infarction, where $\mathrm{H}-$ FABP already is cleared from the circulation while cTnT is still elevated. This finding stresses the importance of sensitive biochemical markers, as no other clinical symptoms of AMI were recorded in these patients.

Renal failure was investigated as possible reason for elevated H-FABP values. ${ }^{(15,25,26)}$ Although kidney dysfunction (creatinine $>120 \mu \mathrm{M}$ ) was observed in 25 out of 58 patients, relative differences between H-FABP and cTnT were not influenced by creatinine cut-off values of 120,150 and $190 \mu \mathrm{M}$, indicating that both proteins are cleared via the kidney. Thus, H-FABP appears to be the more sensitive marker of myocardial injury, unrelated to kidney malfunction.

Interestingly, we found in 13 out of 23 UAP patients elevated levels of NT-proBNP, a recently established marker for heart failure. This indicates that the diagnosis of CHF is still very difficult and that plasma patterns of biochemical markers like NT-proBNP, HFABP and cTnT are needed to differentiate between UAP and CHF although especially in end-stage heart failure (NYHA class III and IV) this can be complicated.

In summary, from this study we conclude that $(i)$ minimal myocyte injury is detectable in a significant proportion of patients with CHF and UAP and, (ii) H-FABP is a more sensitive marker than cTnT for detection of minimal myocyte injury. The significant higher negative predictive value of H-FABP compared to cTnT can be used to rule out future cardiac events and to study the influence of newly developed treatments on CHF patients.

\subsection{References}

1. Newby LK, Goldmann BU, Ohman EM. Troponin: an important prognostic marker and risk stratification tool in non-ST-segment elevation acute coronary syndromes. $J$ Am Coll Cardiol 2003;41:S31-6.

2. Alpert JS, Thygesen K, Altman E, Bassand JP. Myocardial infarction redefined-A consensus document of the joint European Society of Cardiology/American College of Cardiology committee for the redefinition of myocardial infarction. J Am Coll Cardiol 2000;36:959-69. 
3. Setsuta K, Seino Y, Takahasi N, Ogawa T, Sasaki K, et al. Clinical significance of elevated levels of cardiac troponin T in patients with chronic heart failure. Am J Cardiol 1999;84:60811.

4. Setsuta K, Seino Y, Ogawa T, Arao M, Miyatake Y, et al. Use of cytosolic and myofibril markers in the detection of ongoing myocardial damage in patients with chronic heart failure. Am J Med 2002;113:717-22.

5. Sato Y, Yamada T, Taniguchi R, Nagai K, Makiyama T, et al. Persistently increased serum concentrations of cardiac troponin $\mathrm{T}$ in patients with idiopathic dilated cardiomyopathy are predictive of adverse outcomes. Circ 2001;103:369-74.

6. Seino Y, Tomita Y, Takano T, Hayakawa H. Early identification of cardiac events with serum troponin $\mathrm{T}$ in patients with unstable angina. Lancet 1993;342:1236-7.

7. Seino Y, Tomita Y, Hoshino K, Setsuta K, Takano T, et al. Pathophysiological analysis of serum troponin $\mathrm{T}$ release kinetics in evolving ischemic myocardial injury. Jpn Circ J 1996;60:265-76.

8. Yasue H, Yoshimura M, Sumida H, Kikuta K, Kugiyama K, et al. Localization and mechanism of secretion of B-type natriuretic peptide in comparison with those of A-type natriuretic peptide in normal subjects and patients with heart failure. Circ 1994;90:195-203.

9. Davidson NC, Struthers AD. Brain natriuretic peptide. J Hypertens 1994;12:329-36.

10. Remme WJ, Swedberg K. Comprehensive guidelines for the diagnosis and treatment of chronic heart failure. Task force for the diagnosis and treatment of chronic heart failure of the European Society of Cardiology. Eur J Heart Failure 2002;4:11-22.

11. Glatz JFC, van der Vusse GJ. Cellular fatty acid-binding proteins: their function and physiological signification. Prog Lipid Res 1996;3:243-82.

12. Glatz JFC, van der Voort D, Hermens WT. Fatty acid-binding protein as the earliest available plasma marker of acute myocardial injury. J Clin Lig Ass 2002;25:167-77.

13. Nakata T, Hashimoto A, Hase M, Tsuchihaski K, Shimamoto K. Human heart-type fatty acid-binding protein as an early diagnostic and prognostic marker in acute coronary syndromes. Cardiology 2003;99:96-104.

14. Okamoto F, Sohmiya K, Ohkaru Y, Kawamura K, Asayama K, et al. Human heart-type cytoplasmic fatty acid-binding protein (H-FABP) for the diagnosis of acute myocardial infarction. Clinical evaluation of H-FABP in comparison with myoglobin and creatine kinase isoenzyme MB. Clin Chem Lab Med 2000;38:231-8.

15. Wodzig KW, Kragten JA, Hermens WT, Glatz JF, Van Dieijen-Visser MP. Estimation of myocardial infarct size from plasma myoglobin or fatty acid-binding protein. Influence of renal function. Eur J Clin Chem Biochem 1997;35:191-8.

16. Van Dieijen-Visser MP, Dirix JHC, Kooman J, Pinto YM, Hermens WT, et al. Fragmentation of Troponin T in plasma and tissue. Clin Chem Lab Med 2003;41:S11.4.

17. Wodzig KWH, Pelsers MMAL, Van der Vusse GJ, Roos W, Glatz JFC. One-step enzymelinked immunosorbent assay (ELISA) for plasma fatty acid-binding protein. Ann Clin Biochem 1997;34:263-8.

18. Pelsers MMAL, Chapelle JP, Knapen M, Vermeer C, Muijtjens AMM, et al. Influence of age, sex and day-to-day and within-day biological variation on plasma concentrations of fatty acid-binding protein and myoglobin in healthy subjects. Clin Chem 1999;45:441-3.

19. Muller-Bardorff M, Hallermayer K, Schroder A, Ebert C, Borgya A, et al. Improved troponin $\mathrm{T}$ ELISA specific for cardiac troponin $\mathrm{T}$ isoform: assay development and analytical and clinical validation. Clin Chem 1997;43:458-66.

20. Van Nieuwenhoven FA, Kleine AH, Wodzig WH, Hermens WT, Kragten HA, et al. Discrimination between myocardial and skeletal muscle injury by assessment of the plasma ratio of myoglobin over fatty acid-binding protein. Circulation 1995;92:2848-54.

21. Mair J. Cardiac troponin I and T: are enzymes still relevant as cardiac markers? Clin Chim Acta 1997;257:99-115.

22. Davies CH, Harding SE, Poole-Wilson PA. Cellular mechanisms of contractile dysfunction in human heart failure. Eur Heart J 1996;17:189-98. 


\section{Chapter 6}

23. Narula J, Haider N, Virmani R, DiSalvo TG, Kolodgie FD, et al. Apoptosis in myocytes in end-stage heart failure. $N$ Engl J Med 1996;335:1182-9.

24. Olivetti G, Abbi R, Quaini F, Kajstura J, Cheng W, et al. Apoptosis in the failing heart. $N$ Engl J Med 1997;336:1131-41.

25. Gorski J, Hermens WT, Borawski J, Mysliwiec M, Glatz JF. Increased fatty acid-binding protein concentration in plasma of patients with chronic renal failure. Clin Chem 1997;43:193-5.

26. Nayashida N, Chihara S, Tayama E, Akasu K, Kai E, et al. Influence of renal function on serum and urinary heart fatty acid-binding protein levels. J Cardiovasc Surg 2001;42:735-40. 


\section{Early assessment of exercise induced skeletal muscle injury using plasma fatty acid-binding protein}

Part of this chapter is published:

Sorichter S, Mair J, Koller A, Pelsers MMAL, Puschendorf B, et al. Early assessment of exercise induced skeletal muscle injury using plasma fatty acid-binding protein. Brit $J$ Sport Med 1998;32:121-4. 


\subsection{Abstract}

Eccentric muscle contractions have been shown to damage skeletal muscle. In this study we wanted to test whether heart-type fatty acid-binding protein (H-FABP) is a useful plasma marker for the early detection of exercise induced skeletal muscle injury in healthy subjects. Plasma concentrations of H-FABP and Myoglobin (Mb) were measured in six healthy physical education teacher trainees after 20 min of downhill running $(16 \%$ incline; mean lactate $4 \mathrm{mmol} / 1 ; 70 \%$ of maximum oxygen uptake $\left.\left(\mathrm{VO}_{2} \mathrm{MAX}\right)\right)$. Creatine kinase $(\mathrm{CK})$ was measured for comparison. Significant increases were found in plasma H-FABP (mean peak level $50 \mu \mathrm{g} / \mathrm{L}), \mathrm{Mb}(823 \mu \mathrm{g} / \mathrm{L})$, and CK $(491 \mathrm{U} / \mathrm{L}) . \mathrm{Mb}$ and $\mathrm{H}-$ FABP concentrations were already significantly elevated $(p<0.05)$ at $30 \mathrm{~min}$, but $\mathrm{CK}$ not until $2 \mathrm{~h}$ after exercise. Whereas $\mathrm{Mb}$ and H-FABP decreased to normal levels within 24 $\mathrm{h}, \mathrm{CK}$ activity remained elevated for $48 \mathrm{~h}$. The Mb over H-FABP ratio in plasma after exercise induced muscle injury was 15.0 (1.3) (mean (SEM)) (range 7.4 to 31.1 ), which is within the range of ratios calculated for skeletal muscle tissue contents of $\mathrm{Mb}$ and $\mathrm{H}$ FABP, but different from the reported plasma ratio after myocardial injury (2 to 5$)$. In conclusion we can state that after eccentric exercise induced muscle injury, plasma $\mathrm{H}$ $\mathrm{FABP}$ and $\mathrm{Mb}$ increase and decrease more rapidly than $\mathrm{CK}$, indicating that both $\mathrm{H}-\mathrm{FABP}$ and $\mathrm{Mb}$ are more useful than $\mathrm{CK}$ for the early detection of such injuries and the monitoring of injury during repeated exercise bouts. In addition, the Mb over H-FABP ratio in the plasma identifies the type of muscle injured.

\subsection{Introduction}

It is shown that skeletal muscles are often damaged by eccentric muscle contractions, where muscles are lengthened as they produce force, especially after unaccustomed bouts of exercise. ${ }^{(1)}$ The occurrence and extent of such exercise induced muscle injury is routinely assessed from increased blood levels of muscle proteins, as this provides the simplest way of studying the effects of exercise on muscles. The proteins usually measured are $\mathrm{CK}$ and $\mathrm{Mb}$, where the latter generally allows earlier detection of muscle injury than $\mathrm{CK} .{ }^{(1-3)}$ However, neither of these proteins is specific for skeletal muscle, as they are present in relatively high concentrations in the myocardium as well and are released into the plasma after myocardial infarction. ${ }^{(4)}$ Thus far, no absolutely specific marker protein for skeletal muscle injury has been available for routine diagnosis.

$\mathrm{H}-\mathrm{FABP}$ has been introduced as a plasma marker for the early detection of myocardial infarction. ${ }^{(5-7)}$ Both H-FABP $(15 \mathrm{kD})$ and $\mathrm{Mb}(18 \mathrm{kD})$ are low molecular mass cytoplasmatic proteins present in heart as well as skeletal muscle, and each show similar plasma release curves after muscle injury. ${ }^{(6)}$ However, as in skeletal muscle the $\mathrm{Mb}$ content is higher and the H-FABP content lower than in heart muscle ${ }^{(6-8)}$, it was suggested that the ratio of $\mathrm{Mb}$ over H-FABP should be a useful index to identify the type of muscle injured in patients. ${ }^{(6)}$ In heart tissue the Mb to H-FABP ratio is about 2 to 5 , and in skeletal muscles it varies from 20 to 70 , depending on the type of muscle. ${ }^{(6,9)}$

The aims of this study were to investigate whether H-FABP is also a useful plasma marker for the early detection of eccentric exercise induced muscle injury in healthy subjects and whether in this case the assessment of the Mb over H-FABP ratio in plasma can be used to identify skeletal muscle as the source of muscle protein release. For this purpose we measured H-FABP, Mb, CK, and cardiac troponin I (cTnI) in six healthy young subjects before and at several time points after $20 \mathrm{~min}$ of downhill running. 


\subsection{Material and Methods}

\subsubsection{Exercise test}

\section{Probands}

All six male physical education teacher trainees (mean age 26, range 22 to 29) had no physical limitations to exercise and were not involved in any specific training. The risks and benefits of the study were explained, and written informed consent was obtained from each participant. All subjects were instructed to refrain from unaccustomed exercise during the course of the study starting $48 \mathrm{~h}$ before the exercise session.

\section{Warm up protocol}

The 15 min warm up consisted of 5 min running on a treadmill at a speed which corresponded to the individual aerobic threshold, followed by 5 min of stretching the leg muscles and finishing up with three series of eight knee bends.

\section{Eccentric exercise regimen}

The probands successfully performed a test of their maximum oxygen uptake $\left(\mathrm{VO}_{2} \mathrm{MAX}\right)$ on a treadmill ergometer. The exercise session consisted of $20 \mathrm{~min}$ of downhill treadmill running (16\% incline). The exercise intensity (running speed) on the treadmill was heart rate controlled. The target heart rate during downhill running was that found at $70 \%$ of $\mathrm{VO}_{2} \mathrm{MAX}$ in the $\mathrm{VO}_{2} \mathrm{MAX}$ test performed two weeks before downhill running. Blood samples used for the determination of muscle proteins were taken immediately before exercise, and $30 \mathrm{~min}$ and 2, 6, 24, and $48 \mathrm{~h}$ after exercise.

\subsubsection{Laboratory analyses}

\section{Lactate}

Capillary blood samples for the determination of lactate concentration were collected from a prewarmed ear lobe. Immediately $100 \mu 1$ of the sample was mixed with $200 \mu 1$ of a cold $8 \%$ perchloric acid solution and refrigerated until subsequent lactate determination by an enzymatic method (LACT; Boehringer-Mannheim, Mannheim, Germany).

\section{Blood collection}

Blood was collected from a superficial forearm vein in EDTA coated tubes (Sarstedt, Nümbrecht, Germany). CK activity was assayed without delay. Blood samples for $\mathrm{H}-$ FABP, cTnI, and $\mathrm{Mb}$ measurements were immediately centrifuged and the plasma subsequently frozen and stored at $-20^{\circ} \mathrm{C}$ until further analyses.

\section{$H-F A B P$}

Blood samples from 62 apparently healthy blood donors, including 44 men and 18 women, aged $32 \pm 10$ years (mean $\pm \mathrm{SD}$ ) were used to establish the reference range for the H-FABP assay used. H-FABP was determined in plasma by a sandwich ELISA as described in Chapter 3 (sandwich ELISA), using specific monoclonal antibodies. ${ }^{(10)}$

\section{$C K, c T n I$, and $M b$}

These proteins were measured by commercially available assays (CK: Granutest 15, Merck, Darmstadt, Germany; cTnI: Troponin-I Pasteur, Sanofi-Diagnostics-Pasteur, Marnesla-Coquette, France; Mb: Access, Sanofi-Diagnostics-Pasteur). 


\subsubsection{Calculations and statistics}

The ratio of $\mathrm{Mb}$ over $\mathrm{H}-\mathrm{FABP}$ was calculated only for those samples in which both proteins were increased to at least twice their baseline value. ${ }^{(6)}$ For this reason, calculations were not performed for some time points. For the calculation, the individual basal levels of all three proteins were subtracted from the plasma levels measured after exercise. All variables were tested for normal distribution and equal variance. Mean and SEM were calculated to describe continuous variables. Student's paired $t$ test, linear regression, one way analysis of variance for repeated measurements, and post-hoc comparisons by the Student-Newman-Keuls methods were used for intra- and inter-group comparison. $p<0.05$ was considered to indicate statistical significance.

\subsection{Results}

\subsubsection{Plasma reference value}

The mean \pm SD H-FABP concentration in plasma from healthy blood donors was $1.9 \pm 0.8$ $\mu \mathrm{g} / \mathrm{L}$. The upper reference value, calculated non-parametrically as the 97.5 percentile of H-FABP concentrations, was $3.4 \mu \mathrm{g} / \mathrm{L}$. Plasma H-FABP in the six subjects under study before exercise was $3.0 \pm 1.3 \mu \mathrm{g} / \mathrm{L}$, which is not significantly different from that of the blood donors.

\subsubsection{Eccentric exercise}

During exercise, plasma lactic acid levels rose to about $4 \mathrm{mM}$ in all six downhill runners. cTnI could not be detected in any sample taken, but H-FABP, Mb, and CK all increased significantly after exercise. The time to reach peak concentration and return to normal was significantly shorter for H-FABP and Mb than for CK (Fig. 7.1). H-FABP and Mb were already significantly $(p<0.05)$ increased, relative to pre-exercise values, at $30 \mathrm{~min}$ after exercise (mean increase for H-FABP 13.9-fold and for Mb 8.7-fold). Mean peak values were reached for H-FABP $(50 \pm 13 \mu \mathrm{g} / \mathrm{L})$ and $\mathrm{Mb}(826 \pm 230 \mu \mathrm{g} / \mathrm{L})$ between 2 and 6 $\mathrm{h}$ after exercise, while the values found at 24 and $48 \mathrm{~h}$ were not significantly increased (Fig. 7.1). In contrast, the increase in plasma CK activity was not significant at $30 \mathrm{~min}$ after exercise (mean increase 2.1 -fold), but became and remained significant $(p<0.05)$ between 2 and $48 \mathrm{~h}$ after exercise (Figure 7.1). The peak value for CK was reached at $6 \mathrm{~h}$ and amounted to $491 \pm 121 \mathrm{U} / \mathrm{L}$. Peak H-FABP concentrations in individual subjects correlated with peak CK levels $(r=0.74 ; p<0.05)$. A positive correlation was found for the time courses of plasma FABP and $\left.\mathrm{Mb}\left(\mathrm{f}_{(\mathrm{x}}\right)=-7.85+(15.4 \mathrm{x}) r=0.93, p<0.0001\right)$. The calculated $\mathrm{Mb}$ over $\mathrm{H}-\mathrm{FABP}$ ratio was constant after exercise without significant differences. For all blood samples taken after the end of eccentric exercise, the Mb over $\mathrm{H}-\mathrm{FABP}$ ratio (calculated for 20 samples with significantly elevated $\mathrm{Mb}$ and $\mathrm{H}-\mathrm{FABP}$ levels) was $15.0 \pm 1.3$ (mean $\pm \mathrm{SD})$. 


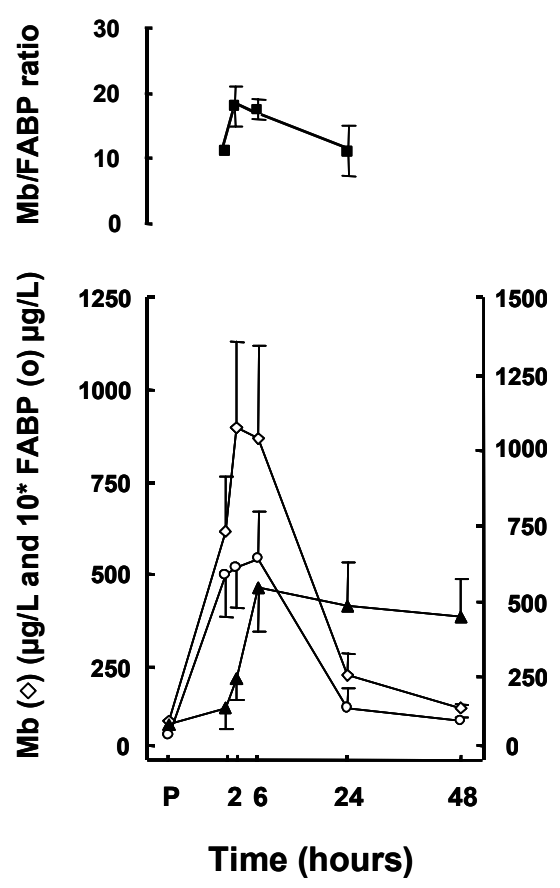

Figure 7.1 Plasma heart-type fatty acid binding protein (H-FABP), Myoglobin (Mb), Creatine Kinase (CK), and the $\mathrm{Mb}$ to $\mathrm{H}-\mathrm{FABP}$ ratio after $20 \mathrm{~min}$ of downhill running on a treadmill (16\% incline; $70 \%$ VO2MAX) in six healthy young athletes. Data are mean (SEM). The $\mathrm{Mb}$ to $\mathrm{H}-\mathrm{FABP}$ ratio was calculated only for those samples in which both proteins were increased to at least twice the baseline value. $\mathrm{H}-\mathrm{FABP}$ and $\mathrm{Mb}$ were both significantly $(p<0.05)$ increased from baseline values at $0.5,2$, and $6 \mathrm{~h}$ after exercise, and CK at 2 , J 6,24 , and $48 \mathrm{~h}$ after exercise. The bar indicates the period of eccentric exercise. $P$, pre-exercise.

\subsection{Discussion}

Unaccustomed exercise bouts especially with eccentric muscle contractions frequently produce skeletal muscle damage, which results in a temporary loss of muscle function and coordination. ${ }^{(1)}$ Increased blood levels of $\mathrm{CK}$ and $\mathrm{Mb}$ are frequently used to diagnose exercise induced muscle damage. ${ }^{(1-3)}$ More recently, H-FABP has been introduced as a plasma marker for the early detection of necrotic muscle injury in patients. ${ }^{(5,6,9)}$

The present study is the first one to show that plasma H-FABP increases after physical exercise by healthy subjects and that its pattern of release into and clearance from the blood is similar to that of $\mathrm{Mb}$. For both $\mathrm{H}-\mathrm{FABP}$ and $\mathrm{Mb}$ a significant increase was reached earlier after exercise $(30 \mathrm{~min})$ than for CK $(2 \mathrm{~h})$, indicating the usefulness of the former for the early detection of muscle injury. In addition, both H-FABP and Mb had returned to baseline values at $24 \mathrm{~h}$ after exercise whereas CK remained elevated until (at least) $48 \mathrm{~h}$ after exercise. The relatively short half-life of $\mathrm{H}-\mathrm{FABP}$ and $\mathrm{Mb}$ in plasma relates to their rapid elimination from plasma mostly by renal clearance. ${ }^{(3,5)}$ Our findings suggest that $\mathrm{H}-\mathrm{FABP}$ and $\mathrm{Mb}$, in comparison with $\mathrm{CK}$, are also more useful for the separate monitoring of muscle injury during repeated exercise bouts. The calculated $\mathrm{Mb}$ over H-FABP ratio (mean value 15.0, range 7.4 to 31.1 ) is comparable with that found in skeletal muscle tissue (20 to 70$).{ }^{(6)}$ cTnI was not detectable in plasma from the investigated athletes, indicating that the source of muscle protein release after downhill running is damaged skeletal muscle rather than heart muscle. ${ }^{(1)}$ Our present results extend the previous (preliminary) observation that plasma H-FABP and Mb increase after heavy exercise on a treadmill, with a calculated Mb over H-FABP ratio of 23 (mean for 4 volunteers) ${ }^{(9)}$, and are also in accordance with the finding that plasma H-FABP and $\mathrm{Mb}$ increase after abdominal aortic surgery, with a calculated Mb over H-FABP ratio varying from 35 to $50{ }^{(6)}$ However, the ratio of the plasma concentrations of Mb over H-FABP 
after physical exercise is different from the ratio of 2 to 5 found after acute myocardial infarction. ${ }^{(6)}$

In conclusion, H-FABP, like $\mathrm{Mb}$, allows earlier assessment of exercise induced skeletal muscle injury than $\mathrm{CK}$, and because of its rapid plasma clearance it is also particularly suited for assessment of recurrent injury. An electrochemical immunosensor for the rapid (about $15 \mathrm{~min}$ ) assay of H-FABP in plasma ${ }^{(12)}$ will be useful for this purpose. In addition, the different ratios of the plasma concentrations of $\mathrm{Mb}$ over H-FABP found after skeletal and myocardial tissue injury reflect the different ratios found in the affected tissue, and thus allow the differentiation whether $\mathrm{Mb}$ and $\mathrm{H}-\mathrm{FABP}$ are released from skeletal muscle or myocardium.

Therefore, we suggest that simultaneous measurement of $\mathrm{H}-\mathrm{FABP}$ and $\mathrm{Mb}$ in plasma could be helpful for the early diagnosis of skeletal muscle damage, as the combination of these markers can give trainers and athletes early and specific information about the exercised skeletal muscles in training sessions and after competition. This information could help to avoid additional skeletal muscle damage or over-training and could allow better control of specific training sessions.

\subsection{References}

1. Clarkson PM, Nosaka K, Braun B. Muscle function after exercise-induced muscle damage and rapid adaptation. Med Sci Sports Exerc 1992;24:512-20.

2. Driessen-Kletter MF, Amerlink GJ, Bar PR, van Gijn J. Myoglobin is a sensitive marker of increased muscle membrane vulnerability. J Neurol 1990;237:234-8.

3. Rodenburg JB, Bar PR, De Boer RW. Relations between muscle soreness and biochemical and functional outcomes of eccentric exercise. J Appl Physiol 1993;74:2976-83.

4. Mair J, Artner-Dworzak E, Lechleitner P, Morras B, Smidt J, et al. Early diagnosis of acute myocardial infarction by a newly developed rapid immunoturbidimetric assay for myoglobin. Br Heart J 1992;68:462-8.

5. Kleine AH, Glatz JFC, Van Nieuwenhoven FA, Van der Vusse GJ. Release of heart fatty acid-binding protein into plasma after acute myocardial infarction in man. Mol Cell Biochem 1992;116:155-62.

6. Van Nieuwenhoven FA, Kleine AH, Wodzig KWH, Hermens WT, Kragten HA, et al. Discrimination between myocardial and skeletal muscle injury by assessment of the plasma ratio of myoglobin over fatty acid-binding protein. Circulation 1995;92:2848-54.

7. Yoshimoto K, Tanaka T, Somiya K, Tsuji R, Okamoto F, et al. Human heart-type cytoplasmic fatty acid-binding protein as an indicator of acute myocardial infarction. Heart Vessels 1995;10:304-9.

8. Sylven C, Jansson E, Book K. Myoglobin content in human skeletal muscle and myocardium: relation to fibre type and size and oxidative capacity. Cardiovasc Res 1984;18:443-6.

9. Van Nieuwenhoven FA, Kleine AH, Keizer HA, et al. Comparison of myoglobin and fatty acid-binding protein as plasma marker for muscle damage in man. Eur $J$ Physiol 1992;421:R40(abstract).

10. Roos W, Eymann E, Symannek M, Duppenthaler J, Wodzig KWH, et al. Monoclonal antibodies to human heart fatty acid-binding protein. J Immunol Methods 1995;183:149-53.

11. Adams JE, Bodor GS, Davila-Roman VG, Delmez JA, Apple FS, et al. Cardiac Troponin I: A marker with high specificity for cardiac injury. Circulation 1993;88:101-6.

12. Schreiber A, Feldbrügge R, Key G, Glatz JFC, Spener F, et al. An immunosensor based on disposable electrodes for rapid estimation of fatty acid-binding protein, an early marker of myocardial infarction. Biosens Bioelectron 1997;12:1131-7. 


\section{Fatty acid binding protein: a new biomarker of nephrotoxicity} in rat.

Part of this chapter is submitted:

Pelsers MMAL, Glatz JFC, Davies D. Fatty acid binding protein: a new biomarker of nephrotoxicity in the rat. Submitted 


\subsection{Abstract}

Biomarkers to detect nephrotoxicity have been studied before, but sensitivity and specificity of urinary- and serum profiles of these markers still need to be improved. The aim of this study was to evaluate various analytes in rat blood and urine and to relate the presence of these analytes with renal damage to specific regions of the rat kidney following the administration of the three nephrotoxic agents: mercuric chloride $\left(\mathrm{HgCl}_{2}\right)$, cyclosporin or gentamicin. Lactate dehydrogenase ( $\mathrm{LDH})$, total protein, heart-type fatty acid-binding protein (H-FABP) and glutathione-S-transferase (GST) in urine showed that $\mathrm{HgCl}_{2}$ induced a broad nephrotoxic effect, while cyclosporin induced only mild injury. Gentamicin administration induced the most severe injury as indicated by significantly elevated urinary levels of LDH, total protein, H-FABP and GST. In conclusion, we can state that the patterns of urinary markers are different for the three nephrotoxins used in this study and that these patterns appear to reflect the location and degree of injury observed by histopathological evaluation of the kidney.

\subsection{Introduction}

Environmental or occupational exposure to toxic heavy metals such as mercury, lead, or cadmium is well known to lead to renal diseases like acute renal failure. ${ }^{(1)}$ Although the exact mechanisms of metal nephrotoxicity remain unclear, histologically characteristic features are lesions that tend to predominate in specific regions of the nephron within specific cells ${ }^{(2)}$, leading to functional alterations as changes in renal plasma flow and glomular filtration rate, and proximal or distal tubular damage. ${ }^{(3)}$ This suggests that certain regions of the nephron are selectively sensitive to specific metals. ${ }^{(2-4)} \mathrm{HgCl}_{2}$ is known to induce oxidative stress in several tissues, leading to acute renal failure in rats. ${ }^{(5)}$ Gentamicin, a widely used drug for the treatment of gram-negative infections, impairs energy production and mitochondrial dysfunction as effects are observed on expression of proteins involved in the citric acid cycle, gluconeogenesis, fatty acid-synthesis, transport and cellular stress responses. ${ }^{(6,7)}$ In addition, free radical production is also reported to be upregulated by gentamicin or the immunosupressive agent cyclosporin. ${ }^{(8,9)}$ The latter also induces inhibition of mitochondrial metabolism. ${ }^{(10)}$

Sensitivity and specificity of biomarkers to detect nephrotoxicity still needs to be improved. ${ }^{(11-14)}$ In this study, the administration of the nephrotoxic agents $\mathrm{HgCl}_{2}$, cyclosporin A and gentamicin was investigated for inducing renal damage to specific regions of the rat kidney. This chapter examines the potential usefulness of a new nephrotoxic biomarker, FABP ${ }^{(15)}$, which can be detected in the urine of rats. In kidney, FABP is located in both the proximal (liver-type FABP; L-FABP) and distal (heart-type FABP; H-FABP) tubulus. ${ }^{(16)}$ H-FABP has been associated with early release following tissue injury to the kidneys. ${ }^{(17)}$ In the present study, the release into urine or plasma of HFABP is compared with changes in other markers of nephrotoxicity, namely the presence of total protein, LDH and GST ( $\alpha$ and $\mu$ isoforms). GSTs are found in general in high concentrations in the renal tubules. In rat, $\alpha$ GST is found mainly in the cells of the proximal renal tubules and $\mu$ GST (human equivalent is $\pi$ GST) in the distal renal tubules. ${ }^{(18)}$ In response to renal tubular injury, these proteins are rapidly released into the urine. 


\subsection{Materials and Methods}

\subsubsection{Experimental animals and study design}

In this study, Wistar derived Alderley Park male rats were used; 36 days old, weight range 115 to $164 \mathrm{~g}$. The animals were individually housed in metabolism cages that allowed for the daily collection of urine samples for a $16 \mathrm{~h}$ collection period between 16.00 and 8.00 the following morning. Urine volume was measured daily starting from 2 days before the start of dosing to the end of the study. The results were assigned to the study day number when urine collection was started (i.e., the urine volume recorded on day 2 of the study was collected overnight of day 1 and was assigned to day 1).

Group I: rats $(\mathrm{n}=5)$ were given daily oral doses $(10 \mathrm{ml} / \mathrm{kg})$ of physiological saline (Phoenix Pharmaceuticals, $0.9 \% \mathrm{w} / \mathrm{v}$ ) and acted as controls. Animals were followed until day 13.

Group II: rats $(\mathrm{n}=5)$ were given a single subcutaneous (sc) dose (2 mg/kg) of $\mathrm{HgCl}_{2}$ (Sigma, $0.2 \mathrm{mg} / \mathrm{ml}$ ). Animals were followed until day 4.

Group III: rats $(\mathrm{n}=5)$ were given daily oral doses $(45 \mathrm{mg} / \mathrm{kg})$ of cyclosporin A (Sandoz Pharmaceuticals, $4.5 \mathrm{mg} / \mathrm{ml}$ ) for 13 days. Animals were followed until day 13 .

Group IV: rats $(\mathrm{n}=5)$ were given oral doses, $(60 \mathrm{mg} / \mathrm{kg}$, twice a day) of gentamicin (Sigma, $12 \mathrm{mg} / \mathrm{ml}$ ) for 10 days. Animals were followed until day 10.

Urine samples were collected on days $-1,2,3,6,8$, and 10. An additional urine sample was collected for the control and animals receiving cyclosporin on day 13. Tail vein blood samples were taken on day $-1,7$ and 11 while a vena cava sample was taken at necropsy on day 4,11 or 14 . At necropsy the kidneys were taken for histopathological examination.

\subsubsection{Analytical Methods}

For both blood and urine, the concentration of total protein and the activity of LDH were assessed spectrophotometrically on the Roche Modular (Method 1929917 and 1876961 respectively, Roche, Switzerland). H-FABP was assessed immunometrically via a sandwich-type ELISA (HyCult biotechnology, Uden, The Netherlands), as described in Chapter $3^{(19)}$, using rat recombinant $\mathrm{H}_{-\mathrm{FABP}^{(20)}}$ as standard (see Chapter 4). The calibration curve ranges from 0 to $12 \mu \mathrm{g} / \mathrm{L}$. GST $(\alpha-$ and $\mu)$ were assessed immunometrically via two specific sandwich-type ELISAs (Biotrin, Dublin, Ireland). Serum creatinine was measured using a modified Jaffe's reaction on the Roche Modular (Method 1875418, Roche Switzerland). Urea was measured by a kinetic UV assay where urea is hydrolysed by urease to form $\mathrm{CO}_{2}$ and ammonia. The ammonia formed then reacts with alpha-ketoglutarate and NADH in the presence of GLDH to yield glutamate and $\mathrm{NAD}^{+}$. The decrease in absorbance due to consumption of NADH is measured kinetically. The urine results were expressed as total excretion over the $16 \mathrm{~h}$ period, taking into account the individual urine volume on that day.

\subsubsection{Statistics}

Student's t-test was used to statistically compare the group mean results for the treated animals with the control animals for each day. 


\subsection{Results}

\subsubsection{Kidney function}

\section{Urine volume}

Urine volumes produced over the $16 \mathrm{~h}$ collection period, for each day of the study, are displayed in Figure 8.1. For the control animals, the mean daily volume up to day 10, were generally similar for each day but increased to about twice the pre-study mean value at the end of the study. For the $\mathrm{HgCl}_{2}$ dosed animals, peak urine volume was observed overnight on day 2. A steady increase in urine volume was seen in the cyclosporin-dosed animals from day 3 , with peak volumes approximately double that of controls being observed on day 6 , but declined to levels below control animals on day 13 . For the gentamicin-dosed animals little change in urine volume occurred until days 6 and 7 when the volume increased by about 3-fold compared to controls. A second peak in urine volume occurred on days 9 and 10. For each dose group individual variability is large with some animals showing a marked increase in urine volume, while others do not appear to be affected.

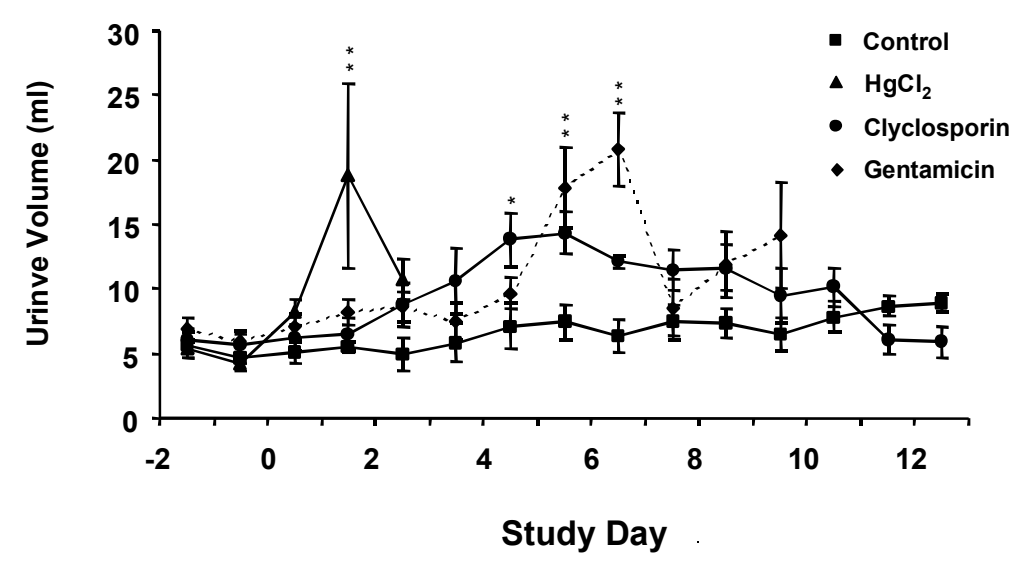

Figure 8.1 Mean $\pm S D$ for the urine volume $(\mathrm{ml})$ excreted each day of the study. Student's t-test analysis was used to compare treatment effect with the control values for each day $\left({ }^{*}, p<0.05 ;{ }^{* *}\right.$, $p<0.01)$.

Plasma urea and creatinine clearance

Plasma urea and creatinine levels were increased (10- and 6-fold, respectively), on day 4 of the study for those animals given the single dose of $\mathrm{HgCl}_{2}$ (Figure 8.2). For the cyclosporin dosed rats, urea and creatinine levels were significantly elevated on days 7 , 11 and 14 with a 2.5-fold increase over the pre-study value for urea while creatinine showed only a marginal increase. For the gentamicin-dosed animals, urea and creatinine were increased 8-fold and 5-fold respectively, on day 11. 


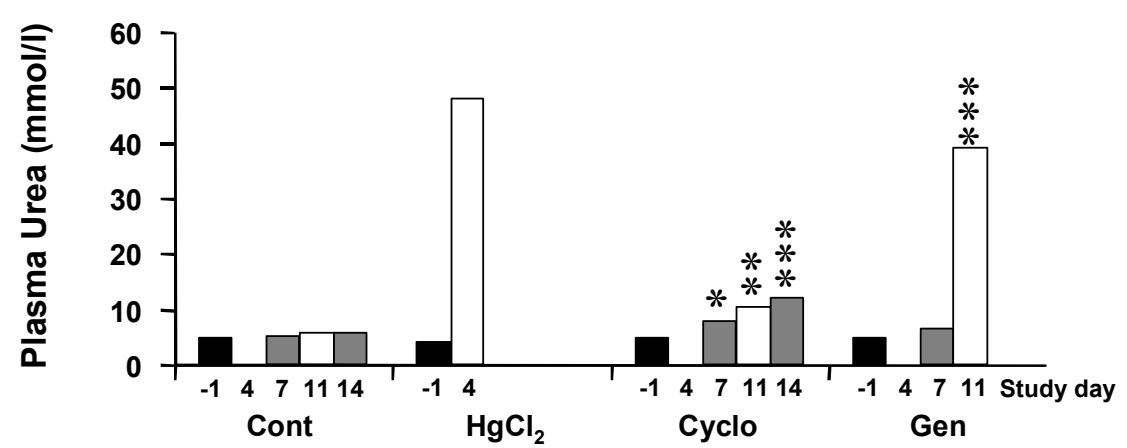

Figure 8.2 Plasma concentrations of the measured analytes expressed as mean \pm SD. Under each bar is indicated the study day on which the samples were collected. Student's t-test analysis was

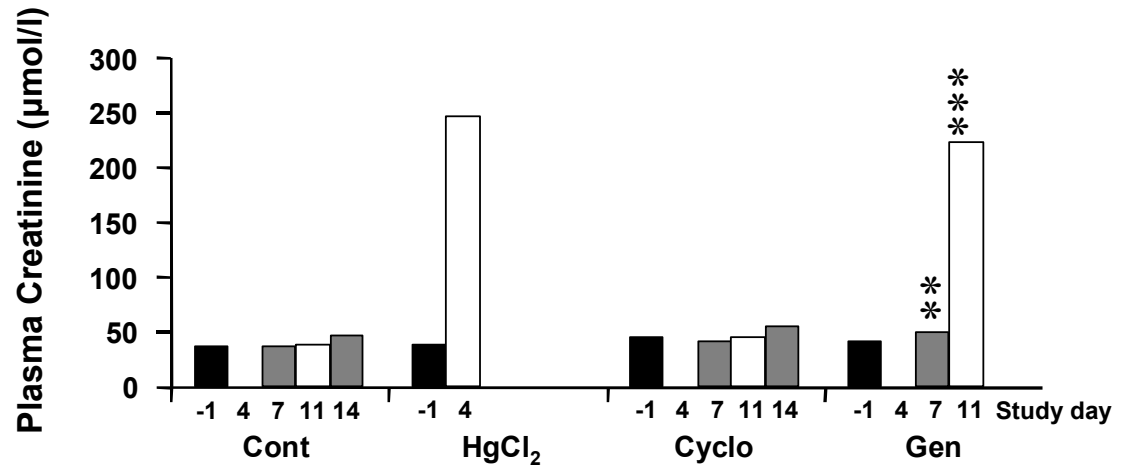
used to compare treatment effect with the control values for each day (* $p<0.05 ; \quad$ ** $p<0.01$; $\left.{ }^{* * *} p<0.001\right)$

\subsubsection{Kidney injury}

The results are expressed as total excretion over the $16 \mathrm{~h}$ urine collection period (ng) since this is considered to provide the most meaningful interpretation of the compound's effect on the kidney.

\section{Total protein}

As the control males mature, an increased excretion of total protein in the urine is observed. In the $\mathrm{HgCl}_{2}$ group the excretion of total protein showed marked increases on day 2 with values that were 2 to 10 fold higher than controls (Fig. 8.3, top panel). The values had returned to control levels in the urine samples collected overnight on day 3 . With cyclosporin, a decrease in the amount of protein excreted was observed from day 2 , and the protein values remained constant and did not show the increase in protein excretion shown by the control animals. This difference was statistically significant $(p<0.05)$ from day 6 on. For the gentamicin-treated rats, an increase in total protein was seen from day 2 , with a maximum 6 -fold increase being observed on day 8 , and a 4 -fold increase being observed on day 10 .

\section{$L D H$}

Lactate dehydrogenase was evaluated as conventional enzyme marker of nephrotoxicity and is presented in Figure 8.3, lower panel. The urinary activities of this enzyme were very similar with no change in controls or cyclosporin dosed animals over the study period. $\mathrm{HgCl}_{2}$ did induce a slight increase in total LDH activity on day 2, but this was not statistically significant. In the gentamicin-treated group, LDH activity showed a progressive increase from day 2 with maximum values being seen on day 8 before the values declined on day 10 . 

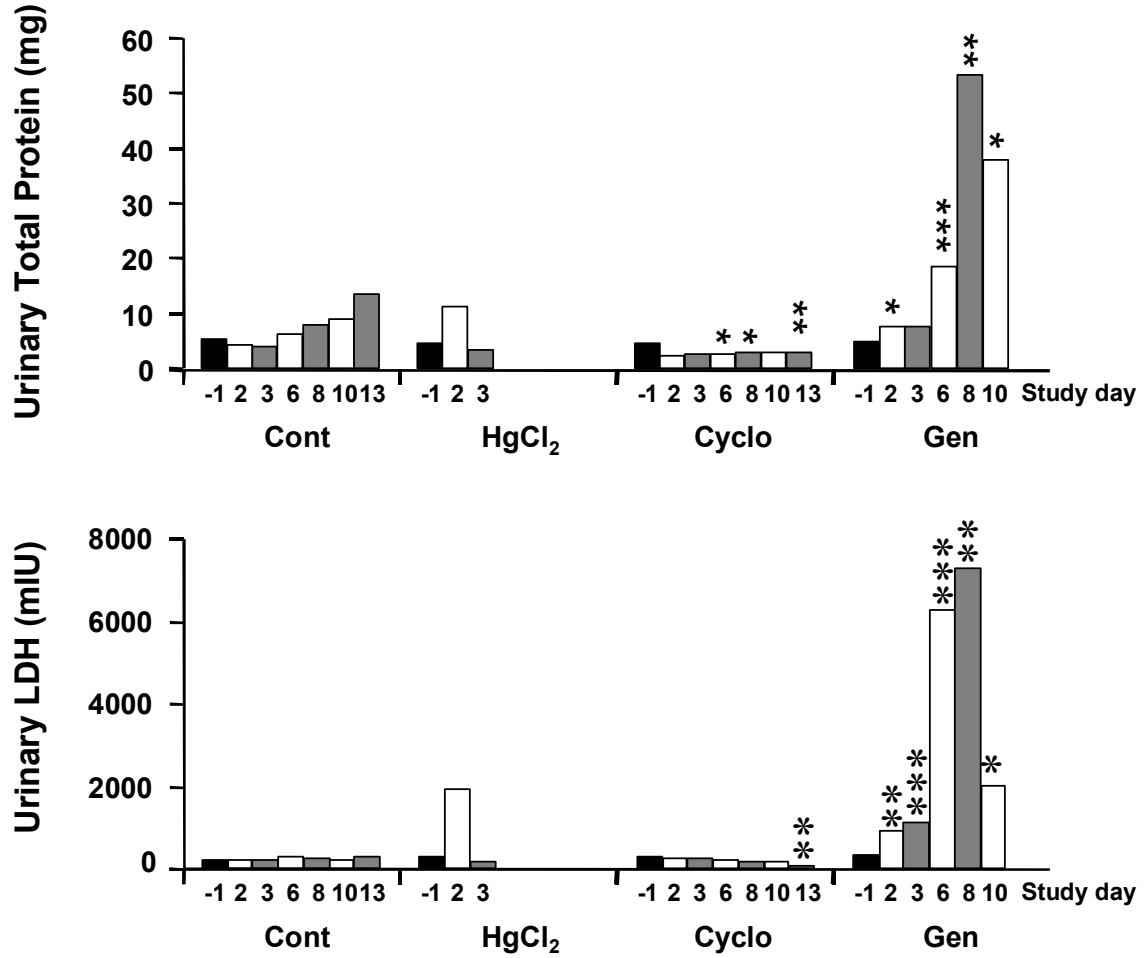

Figure 8.3 Urine daily excretion over $16 \mathrm{~h}$ for total protein (top panel) and lactate dehydrogenase (lower panel). Other information as described in the legend of Figure 8.2.

\section{H-FABP}

Plasma H-FABP values $(\mu \mathrm{g} / \mathrm{L})$ were only elevated in the gentamicin-dosed animals on day 11 and on day 14 of the cyclosporin-dosed animals (Fig 8.4, top panel).

Total $16 \mathrm{~h}$ excreted urinary H-FABP values (ng) in the control animals were significantly lower on days 6 and 8 compared to the other days (Fig 8.4, lower panel). The same pattern was noticed by addition of cyclosporin, but $\mathrm{HgCl}_{2}$ showed an increase on day 2 in urinary H-FABP content, followed by a decrease on day 3. Gentamicin induced the most prominent changes in urinary H-FABP as significant elevations are observed with a peak on day 8 where the concentration of H-FABP in the urine was 60 -fold greater than prestudy, with $7554 \mathrm{ng}$ compared to $126 \mathrm{ng}$ for the control animals.

\section{GST}

$\alpha$ GST shows a strong rise in total excretion in the $\mathrm{HgCl}_{2}$ group, compared to control samples (Fig 8.5, top panel). The latter also show a rise during aging. In cyclosporindosed rats, effects on $\alpha$ GST secretion are minor but significant. Gentamicin-dosed rats, however, show a significant rise in total $\alpha$ GST secretion from day 2 to 14, with strong fluctuations.

$\mu$ GST also shows a strong rise in total excretion in the $\mathrm{HgCl}_{2}$ group, compared to control samples (Fig 8.5, lower panel). On the other hand, cyclosporin induces a more significant $\mu$ GST release than $\alpha$ GST, while gentamicin shows much lower total $\mu$ GST excretion than $\alpha$ GST. 

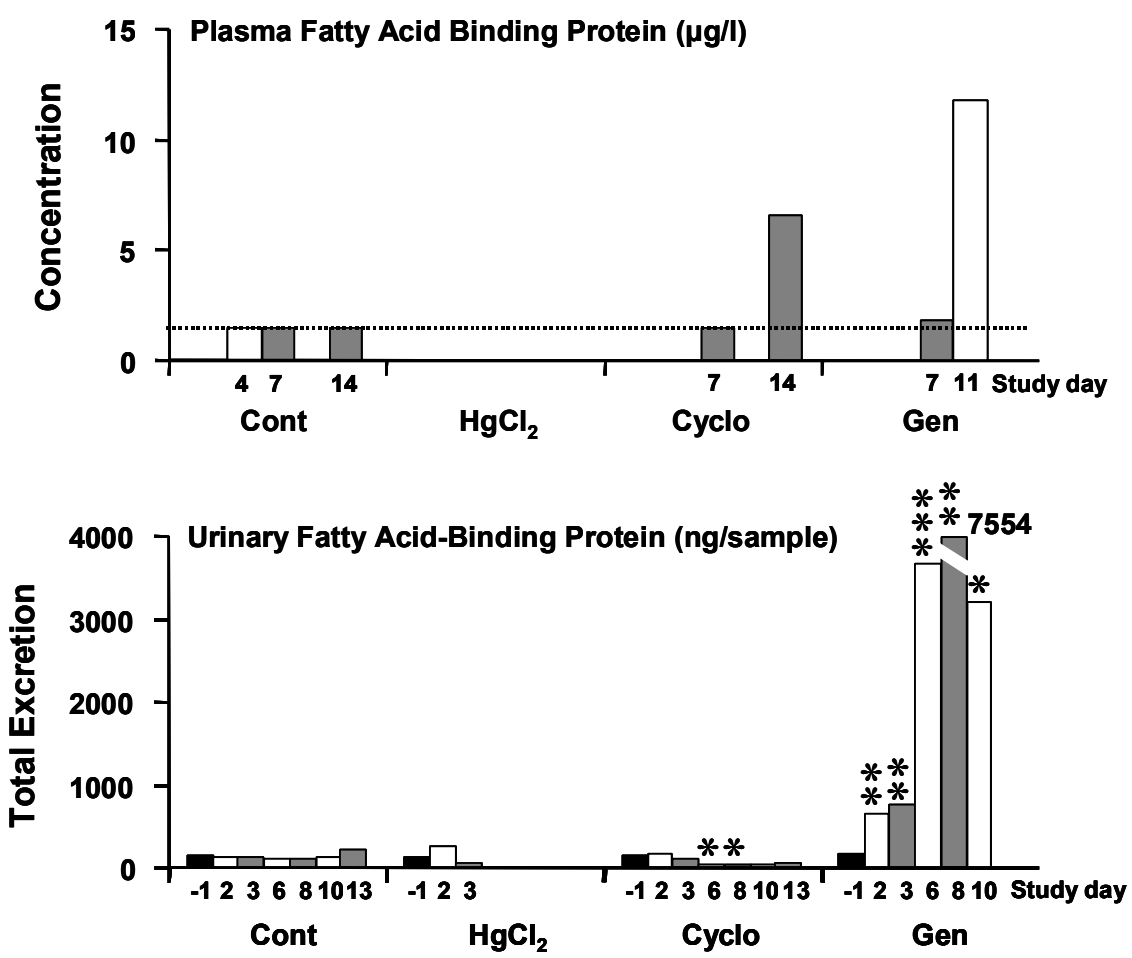

Figure 8.4 Plasma values (top panel) and urine daily excretion over $16 \mathrm{~h}$ (lower panel) for $\mathrm{H}$ FABP. Other information as described in the legend of Figure 8.2.
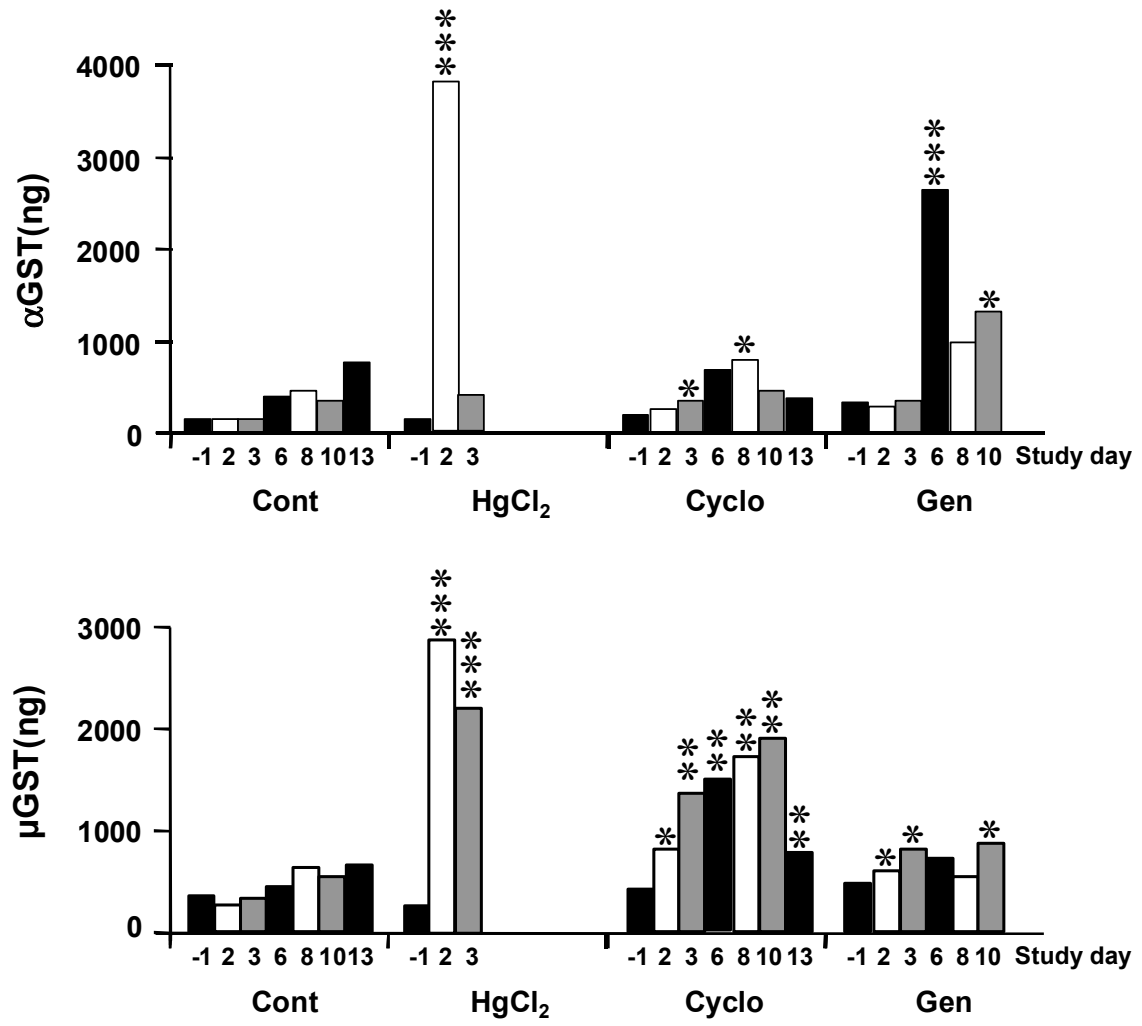

Figure 8.5 Urine daily excretion over $16 \mathrm{~h}$ for $\alpha$-GST (top panel) and $\mu$-GST (lower panel). Other information as described in the legend of Figure 8.2. 


\section{Histopathology}

Rats dosed with $\mathrm{HgCl}_{2}$ showed severe nephropathy at termination, primarily focused on the pars recta, which showed severe necrosis in all five rats (Table 8.1). The proximal convoluted tubules showed minimal to mild necrosis. $\mathrm{HgCl}_{2}$ administration also affected the more distal components of the nephron including Loop of Henle, thick ascending tubules and, to some degree, distal convoluted tubules. All five animals showed a moderate regeneration of the thick ascending tubules but only minimal to mild changes were seen in the other regions. Rats dosed with cyclosporin A showed a mild or moderate nephropathy, primarily affecting ascending and distal tubules.

Rats dosed with gentamicin showed severe nephropathy affecting all areas of the tubules. The most severe changes were focused on the proximal convoluted tubules where all the rats showed severe damage, the presence of protein casts and a high degree of regenerative basophilia. In these animals a mild necrosis of the pars recta was also observed accompanied by a more pronounced regenerative basophilia. Mild to moderate regenerative changes were seen in the Loop of Henle and thick ascending tubules but the distal convoluted tubules showed a mild necrosis and a marked regenerative basophilia, probably indicative of a previous damage. The collecting ducts appear to be mildly affected by the administration of gentamicin and, unlike for the other treatments, the tubules show accumulation of cellular debris and protein casts associated with interstitial inflammatory cell infiltration.

Table 8.1 Summary of pathology tubular damage.

\begin{tabular}{|c|c|c|c|c|c|c|}
\hline & \multicolumn{5}{|c|}{ Summary of degeneration/necrosis/regeneration } \\
\hline & $\begin{array}{c}\text { Proximal } \\
\text { convoluted }\end{array}$ & $\begin{array}{c}\text { Pars } \\
\text { recta }\end{array}$ & Loop & $\begin{array}{c}\text { Thick } \\
\text { ascending }\end{array}$ & $\begin{array}{c}\text { Distal } \\
\text { convoluted }\end{array}$ & $\begin{array}{c}\text { Collecting } \\
\text { duct }\end{array}$ \\
\hline $\mathrm{HgCl}_{2} \mathbf{2} \mathrm{mg} / \mathrm{kg}$ & ++ & ++++ & ++ & +++ & ++ & + \\
\hline $\begin{array}{c}\text { Cyclosporine } \\
\mathbf{4 5} \mathrm{mg} / \mathrm{kg} / \text { day }\end{array}$ & + & + & & ++ & ++ & \\
\hline $\begin{array}{c}\text { Gentamicine } \\
\mathbf{1 2 0} \mathrm{mg} / \mathrm{kg} / \text { day }\end{array}$ & ++++ & ++ & ++ & +++ & +++ & + \\
\hline
\end{tabular}

+ , minimal effect; ++, mild effect; +++ moderate effect; ++++, severe effect

\subsection{Discussion and conclusion}

With $\mathrm{HgCl}_{2}$, renal damage occurred within 2 days of administration which was only detectable by elevated urinary levels of both GST isoforms, indicating proximal and distal tubular injury. Histopathology indicated damage to both the pars recta and distal tubules with little damage to the proximal tubules. The renal function, however, was largely affected as indicated by an increased urine volume (decreased water resorption), leading to increased plasma creatinine and urea levels.

In cyclosporin-treated animals, the histopathology revealed damage primarily to the ascending and distal tubules which was confirmed by a strong increase in urinary levels of the distally located $\mu$ GST levels. Surprisingly, distally located H-FABP was decreased in urine after cyclosporin treatment which might be explained by the fact that $\mathrm{H}-\mathrm{FABP}$ is released via another route into the circulation instead of urine. Total protein and LDH were also reduced compared to pre-study and the control values for each study day. Unfortunately, no plasma GST levels were determined to confirm this hypothesis. The degree of kidney damage is considered as modest since the plasma urea increases 
were quite small and the increase in urine volume was maximal on day 6 , before returning to control values by the end of the study.

Gentamicin produced clear histological evidence of damage to the proximal convoluted tubules with marked epithelial necrosis, which is shown also by significantly elevated urinary levels of proximally located $\alpha$ GST. Other more distal regions of the nephron were also affected as shown by severely elevated levels of H-FABP and $\mu$ GST. These changes were associated with a marked increase in urine volume and plasma urea on day 11. Increases in LDH and total protein were seen from day 2 with further marked increases in all four parameters from day 6 onwards. Increases in LDH and total protein were evident prior to increases in plasma urea concentrations although no plasma samples were collected between days 6 and 11 .

In conclusion, the patterns of urinary markers are different for the three nephrotoxins used in this study and these patterns appear to reflect the location and degree of damage observed by histopathological evaluation of the kidney. Both plasma and urinary H-FABP levels are suitable markers for detection of kidney distal tubular injury. In future studies, next to H-FABP, L-FABP might be investigated as marker for detection of injury to the proximal kidney tubular cells.

\subsection{References}

1. Roels HA, Hoet P, Lison D. Usefulness of biomarkers of exposure to inorganic mercury, lead, or cadmium in controlling occupational and environmental risks of nephrotoxicity. Ren Fail 1999;21:251-62.

2. Diamond GL, Zalups RK. Understanding renal toxicity of heavy metals. Toxicol Pathol 1998;26:92-103.

3. Girardi G, Elias MM. Verapamil protection against mercuric chloride-induced renal glomular injury in rats. Toxicol Appl Pharmacol 1988;152:360-5.

4. Berndt WO. The role of transport in chemical nephrotoxicity. Toxicol Pathol 1998;26:52-7.

5. Goering PL, Fisher BR, Noren BT, Papaconstantinou A, Rojko JL, et al. Mercury induced regional and cell-specific stress protein expression in rat kidney. Toxicol Sci 2000;53:447-57.

6. Charlwood J, Skehel JM, King N, Camilleri P, Lord P, et al. Proteomic analysis of rat kidney cortex following treatment of gentamicin. J Proteome Res 2002;1:73-82.

7. Sundin DP, Sandoval R, Molitoris BA. Gentamicin inhibits renal protein and phosphilipid metabolism in rats: implications involving intracellular trafficking. $J$ Am Soc Nephrol 2001;12:114-23.

8. Baliga R, Ueda N, Walker PD, Shah SV. Oxidant mechanisms in toxic acute renal injury. Drug Metab Rev 1999;31:971-97.

9. Kumar KV, Shifow AA, Naidu MU, Ratnakar KS. Carvedilol: a beta blocker with antioxidant property protects against gentamicin-induced nephrotoxicity in rats. Life Sci 2000;66:260311.

10. Serkova N, Klawitter J, Niemann CU. Organ-specific response to inhibition metabolism by cyclosporin in the rat. Transplant Int 2003;16:748-55.

11. Bernard A, Lauwerys R. Epidemiological application of early markers of nephrotoxicity. Toxicol Lett 1989;46:293-306.

12. Price RG, Taylor SA, Chivers I, Arce-Tomas M, Crutcher E, et al. Development and validation of new screening tests for nephrotoxic effects. Hum Exp Toxicol 1996;15:S10-9.

13. Taylor SA, Chivers ID, Price RG, Arce-Tomas M, Milligan P, et al. The assessment of biomarkers to detect nephrotoxicity using an integrated database. Environ Res 1997;75:23-33.

14. Loeb W. The measurement of renal injury. Toxicol Pathol 1998;26:26-8.

15. Glatz JFC, Van der Vusse GJ. Cellular fatty acid-binding proteins: their function and physiological signification. Prog Lipid Res 1996;3:243-82. 
16. Maatman R, Van Kuppevelt T, Veerkamp J. Two types of fatty acid-binding protein in human kidney. Isolation, characterization and localization. Biochem J 1991;273:759-66.

17. Gok MA, Pelsers MMAL, Glatz JFC, Bhatti AA, Shenton B, et al. Comparison of perfusate activities of glutathione S-transferase, alanine aminopeptidase and fatty acid-binding protein in the assessment of non-heart-beating donor kidneys. Ann Clin Biochem 2003:40:252-8.

18. Strange R, Spiteri M, Ramachandran S, Fryer A. Glutathione-S-transferase family of enzymes. Mutat Res 2001;482:21-6.

19. Wodzig KW, Pelsers MMAL, van der Vusse GJ, Roos W, Glatz JFC. One-step enzymelinked immunosorbent assay (ELISA) for plasma fatty acid-binding protein. Ann Clin Biochem 1997;34:263-8.

20. Schaap F, Specht B, van der Vusse GJ, Börchers T, Glatz JFC. One-step purification of rat heart-type fatty acid-binding protein expressed in Escherichia coli. J Chromatogr Biomed Appl 1996; 679:61-7. 


\section{Perfusate levels of glutathione S-transferase, alanine amino- peptidase and heart-type fatty acid-binding protein in the viability assessment of non-heart-beating donor kidneys}

Can perfusate levels of tissue damage markers predict long-term renal function posttransplant?

\section{Part of this chapter is published:}

Gok MA, Pelsers MMAL, Glatz JFC, Shenton BK, Buckley PE, et al. Do tissue damage markers used to assess machine perfused NHBD kidneys predict long term renal function post-transplant? Clin Chim Acta 2003;338:33-43.

Gok MA, Pelsers MMAL, Glatz JFC, Shenton BK, Peaston R, et al. Use of two biomarkers of renal ischemia to assess machine-perfused non-heart-beating donor kidneys. Clin Chem 2003;49:172-5.

Gok MA, Pelsers MMAL, Glatz JFC, Bhatti AA, Shenton BK, et al. Comparison of perfusate activities of glutathione S-transferase, alanine aminopeptidase and fatty acidbinding protein in the assessment of non-heart-beating donor kidneys. Ann Clin Biochem 2003:40:252-8.

Gok MA, Pelsers MMAL, Glatz JFC, Shenton BK, Buckley PE, et al. Creatinine clearance and viability biomarkers of machine perfused non-heart-beating donors: is there a correlation? Transplant Proceed 2003;35:768. 


\subsection{Abstract}

With a universal shortage of donor organs, screening and selection of marginal kidneys from non-heart-beating donors (NHBDs) provides a valuable source for transplantation. Pre-transplant viability assessment is based on a combination of flow characteristics and assessment of ischemic tissue injury during NHBD kidney machine perfusion by measurement of total glutathione-S-transferase (tGST) activity. Successful viability screening has facilitated 74 renal transplants from 63 NHBDs within the Newcastle (UK) transplant centre since 1998, with a first-year graft survival of $90.5 \%$. Alanine aminopeptidase (Ala-AP) and heart-type fatty acid-binding protein (H-FABP) were investigated as alternative biochemical markers to tGST for pre-transplantation viability assessment. They were measured, together with tGST, in tissue perfusate samples from 74 machineperfused kidneys from controlled (intensive care department; withdrawal of treatment) and uncontrolled (accident and emergency department) NHBDs. Samples were taken on $0,1,2,3$ and $4 \mathrm{~h}$ perfusion. tGST was measured enzymatically, while Ala-AP and H-FABP were measured immunochemically. During machine perfusion, a parallel response was seen for each of the three markers in the perfusates of controlled and uncontrolled NHBD kidneys over the 4-h perfusion period. The levels of all markers were significantly higher in uncontrolled versus controlled donors and in discarded versus transplanted kidneys. A highly significant correlation was obtained between tGST, Ala-AP activities and HFABP concentration $(p<0.001)$ in corresponding samples, but with a clear tendency for H-FABP to be the most sensitive marker of ischemic kidney injury. No correlation was found between pre-transplant biomarker concentrations and long-term renal function, as determined by creatinine clearance rate. tGST, Ala-AP and H-FABP represent comparable pre-transplant indicators of immediate kidney viability and short-term kidneyfunction, with $\mathrm{H}-\mathrm{FABP}$ tending to be the most sensitive marker. Although the biomarkers do not predict the efficacy of renal function in the longer term, the use for short-term screening of kidney function does lead to a survival rate of NHBD kidneys which is sufficient to serve as an important source to match the increasing waiting lists.

\subsection{Introduction}

Renal transplantation is a recognized treatment for end-stage renal failure, offering a better quality of life, independence from dialysis, better survival rates, and decreased cardiovascular complications. ${ }^{(1)}$ Recently, continued increases in the prevalence of endstage renal failure and the length of transplantation waiting lists have not been matched by an increased supply of donors from the traditional brainstem dead donors or living donors. This increasing shortfall in the availability of donor organs for transplantation has led to a renewed interest in the non-heart-beating donor (NHBD) as a potential source of transplantable kidneys. It has been estimated that the UK donor pool could be increased by 20 to $45 \%$ by the universal inclusion of NHBD derived kidneys. ${ }^{(1)}$ However, a major problem with the use of such kidneys is the inevitable tissue damage sustained from periods of warm ischemia. This ischemic tissue injury associates the use of NHBD kidneys with two adverse conditions, namely primary nonfunction (PNF) and delayed graft function (DGF). Thus the success of NHBD renal transplants depends on the efficacy of pre-transplant organ preservation and viability assessment to screen-out damaged kidneys that will never work. Machine preservation using continuous hypothermic pulsatile perfusion has great advantages in preventing warm ischemia 
induced tissue injury and has been adopted in NHBD kidney screening initiatives. ${ }^{(2)}$ Perfusion characteristics (flow, pressure, resistance, temperature, weight gain) with biochemical marker analysis of kidney effluents are used to assess viability. Although a number of such parameters have been investigated with mixed success, the quantification of the enzyme glutathione-S-transferase (GST) is currently regarded as the most promising. However, there is still no totally reliable biochemical marker to differentiate viable and non-viable kidneys. ${ }^{(3)}$

The objective of the present investigation was to compare the ability of two novel potential biochemical markers, alanine aminopeptidase (Ala-AP) ${ }^{(4)}$ and heart-type fatty acid-binding protein $(\mathrm{H}-\mathrm{FABP})^{(5)}$ with the more routinely established biochemical marker, GST, to indicate renal tissue injury in machine perfusion pretransplant and to predict long-term renal function. The use of controlled and uncontrolled NHBD kidneys provided a differential model of ischemia. Controlled donors represented donors from intensive therapy/high-dependency unit referrals (withdrawal of treatment); these donors had reduced primary warm ischemic times (WIT). Uncontrolled donors represented donors from Accident and Emergency Department referrals who had suffered cardiorespiratory arrest and had generally undergone a period of resuscitation; these donors had longer primary WITs.

The measurement of Ala-AP in urine as an index of tissue damage in renal disease has been described previously, including the assessment of kidney function posttransplant. ${ }^{(4,6,7)}$ However, with the exception of the preliminary report by Balupuri et al. ${ }^{(2)}$, the use of Ala-AP as a potential biochemical marker of tissue injury in human NHBD kidneys prior to transplant has not been described. Although H-FABP has been reported as a sensitive biochemical marker of myocardial damage following myocardial infarction, it has not been previously investigated as a marker of tissue injury in NHBD kidneys.

\subsection{Materials and methods}

\subsubsection{Donor kidneys}

NHBD kidneys $(\mathrm{n}=126)$ were procured from 63 donors, and categorized with established criteria (Table 9.1). ${ }^{(8)}$ Maastricht category II (uncontrolled) donors were referred from the local Accident and Emergency Department, following cardiac arrest which was unresponsive to cardiopulmonary resuscitation. Maastricht category III (controlled) donors were referred from Intensive Care Units, following withdrawal of supportive therapy (Table 9.1). Uncontrolled donor kidneys predominantly had longer primary warm ischemic times and therefore greater ischemic insult than controlled donor kidneys. In total, 74 renal transplants were performed, of which $45.9 \%$ (34 of 74) involved uncontrolled donor kidneys and 54.0\% (40 of 74) involved controlled donor kidneys.

In all cases a bolus of 25000 IU of heparin was administered systemically (immediately prior to declaration of death) and a femoral cut-down performed to insert a doubleballoon triple-lumen catheter into the aorta, through which $20 \mathrm{~L}$ of heparinized $(5000$ IU/L) preservation fluid was perfused. After donor family consent was obtained, the kidneys were removed (secondary warm ischemic time) and machine perfused for 4 to 8 $\mathrm{h}$ using the Newcastle hypothermic preservation system, primed with $500 \mathrm{~mL}$ of modified University of Wisconsin organ preservation solution. ${ }^{(9,10)}$ A variety of parameters, including temperature, flow rate, perfusion pressure and perfusion resistance, 
were measured on samples of effluent taken on an hourly basis. A total of 5 perfusates were collected for each donor kidney; 1 pre-perfusion sample and 4 samples up to $4 \mathrm{~h}$ of perfusion. The perfusate GST levels were determined in 'real time' with prior arrangement with the Biochemistry Department. Further perfusate samples were taken and immediately frozen at $-20^{\circ} \mathrm{C}$ for subsequent analysis of Ala-AP and H-FABP.

Table 9.1 Maastricht classification of the non-heart-beating donors and the outcome of the kidneys.

\begin{tabular}{|l|l|c|c|}
\hline \multicolumn{5}{|c|}{ Outcome of the kidneys } \\
\hline Maastricht category & Description & Transplanted & Discarded \\
\hline I (uncontrolled) & Dead on arrival & 0 & 0 \\
\hline II (uncontrolled) & Unsuccessful resuscitation & 34 & 41 \\
\hline III (controlled) & $\begin{array}{l}\text { Withdrawal of treatment } \\
\text { awaiting cardiorespiratory arrest }\end{array}$ & 36 & 11 \\
\hline IV (controlled) & $\begin{array}{l}\text { cardiorespiratory arrest while } \\
\text { brain dead }\end{array}$ & 4 & 0 \\
\hline
\end{tabular}

\subsubsection{Measurement of biochemical markers}

GST is a microsomal enzyme (molecular mass $26 \mathrm{kD}$, mostly appearing as dimer of 52 $\mathrm{kD})$ with a wide tissue distribution. It takes part in detoxification reactions via conjugation of metabolites with glutathione. ${ }^{(11)}$ Its use in transplant viability assessment was investigated in the late $1970 \mathrm{~s}^{(12)}$ In human kidney, two renal iso-enzymes of GST have been identified, $\alpha$-GST and $\pi$-GST, which are located in the proximal and distal tubules, respectively. Tissue damage resulting from prolonged warm ischemia results in the release of $\alpha$-GST and the usefulness of this parameter as a predictor of NHBD renal transplant outcome has been reported. ${ }^{(3)}$ As $\alpha$-GST is measured via a time-consuming immunoassay (Biotrin, Ireland), Balupuri et al. compared the relative merits of total GST (tGST) and $\alpha$-GST as markers of NHBD renal tissue injury ${ }^{(13)}$ and demonstrated that a spectrophotometrically assay for tGST activity could reliably substitute $\alpha$-GST. Total GST was measured using a spectrophotometric assay as previously described. ${ }^{(14)}$ All analyses were performed at $25^{\circ} \mathrm{C}$ using a Cobas Mira automated analyzer (Roche Diagnostics, Lewes, Sussex). A calibration curve was constructed using a series of standards prepared from a Maastricht standard diluted in phosphate buffer $(0.1 \mathrm{M}, \mathrm{pH}$ 5.9).

Ala-AP is an ectopeptidase (molecular mass $100 \mathrm{kDa}$ ) that is located in the cytosol and plasma membrane of various tissues and is thought to be involved both in the generalized process of intracellular protein turnover as well as in the regulation of physiologically active peptides. ${ }^{(15,16)}$ The measurement of urinary Ala-AP as an index of tissue damage in renal disease has been described previously. ${ }^{(6)}$ Ala-AP activity was measured using a specific fluorometric assay as previously described. ${ }^{(17)}$

FABP is a transport protein (molecular mass $15 \mathrm{kDa}$ ) that is involved in the translocation of long-chain fatty acids from the membrane through the cytoplasm to their site of $\beta$ oxidation in the mitochondria. Serum H-FABP has been reported to be a sensitive and quantitative biochemical marker of myocardial injury following myocardial infarction. ${ }^{(18,19)}$ In the renal parenchyma, two isoforms, H-FABP and liver-type (LFABP), have been located in the distal and proximal renal tubules, respectively. ${ }^{(20,21)}$ 
Heart-type FABP (H-FABP) was assayed using a sandwich ELISA assay (HyCult biotechnology, Uden, the Netherlands) as described in Chapter 3, using recombinant $\mathrm{H}-$ FABP as standard. ${ }^{(22,23)}$ All biochemical marker results were corrected for $100 \mathrm{~g}$ kidney tissue mass.

Venous blood was collected into a vacutainer tube containing serum gel separator and allowed to clot for $30 \mathrm{~min}$ prior to centrifugation at $1300 \mathrm{~g}$ for $10 \mathrm{~min}$. Serum creatinine was measured using a modified Jaffe's reaction on an Olympus AU 640 analyser.

\subsubsection{Renal function}

The creatinine clearance for individual NHBD renal transplant recipients was determined by the Cockcroft-Gault formula using the lowest serum creatinine in the post-operative period ( 2 to 4 years). The lowest serum creatinine was generally found within the $3^{\text {rd }}-48^{\text {th }}$ month post-operative period.

\subsubsection{Statistical analysis}

Statistical evaluation of data between groups of NHBD kidneys (i.e., transplanted versus discarded; controlled versus uncontrolled) was performed using the Mann-Whitney $U$ test, with $p<0.05$ as the level of significance. The coefficient of determination $r^{2}$ was used to determine the linear relationship between the GST/Ala-AP and GST/FABP scatterplot data. Biomarker analysis was performed on all perfusates whether or not the kidney was used or discarded.

\subsection{Results}

\subsubsection{Perfusion data}

The perfusate levels for tGST, Ala-AP and H-FABP increased from time T0 to T2, and reached plateau levels up to T4 (Fig. 9.1). A parallel response is seen for all three biomarkers in perfusates of controlled and uncontrolled donors, being low in the optimal kidneys (controlled donors). The differences between the donor groups are especially notable at time T3. A similar pattern is observed for the transplanted and discarded kidneys although only tGST was used in the viability assessment (Fig. 9.2). The perfusate tGST levels in some of the discarded kidneys are below the critical level of 200 IU/L/100g, as these kidneys had failed on other parameters as in Table 9.2. There were comparatively higher perfusate levels of tGST, Ala-AP and H-FABP at time T4 in discarded and category II donor kidneys, than transplanted and category III donor kidneys. This reflects a greater ischemic insult and damage in these donor groups (Fig. 9.3 and 9.4). Fig. 9.5a and 9.5b illustrate the scatterplot of paired "Ala-AP and tGST" and "H-FABP and tGST" values respectively for all perfused kidneys. NHBD kidneys of decreased viability as in the uncontrolled and discarded group show more scatter in the paired values ("Ala-AP-GST" and "H-FABP-GST"), which is represented in the higher segment of the linear regression line.

\subsubsection{Transplantation data}

There were 34 renal transplants using uncontrolled donors and 40 using controlled donors, with lower discard rates perceived with the controlled donors (Tables 9.1 and 
9.2). The two groups of donors were matched for donor and recipient factors. Warm ischemic time was significantly lower in controlled than in uncontrolled donors (Table 9.2). The first-year graft survival rates were $83 \%$ and $97 \%$ in recipients of uncontrolled and controlled NHBD kidneys, whereas the first-year patient survival rates were $82 \%$ and $94 \%$ in recipients of uncontrolled and controlled NHBD kidneys, respectively.
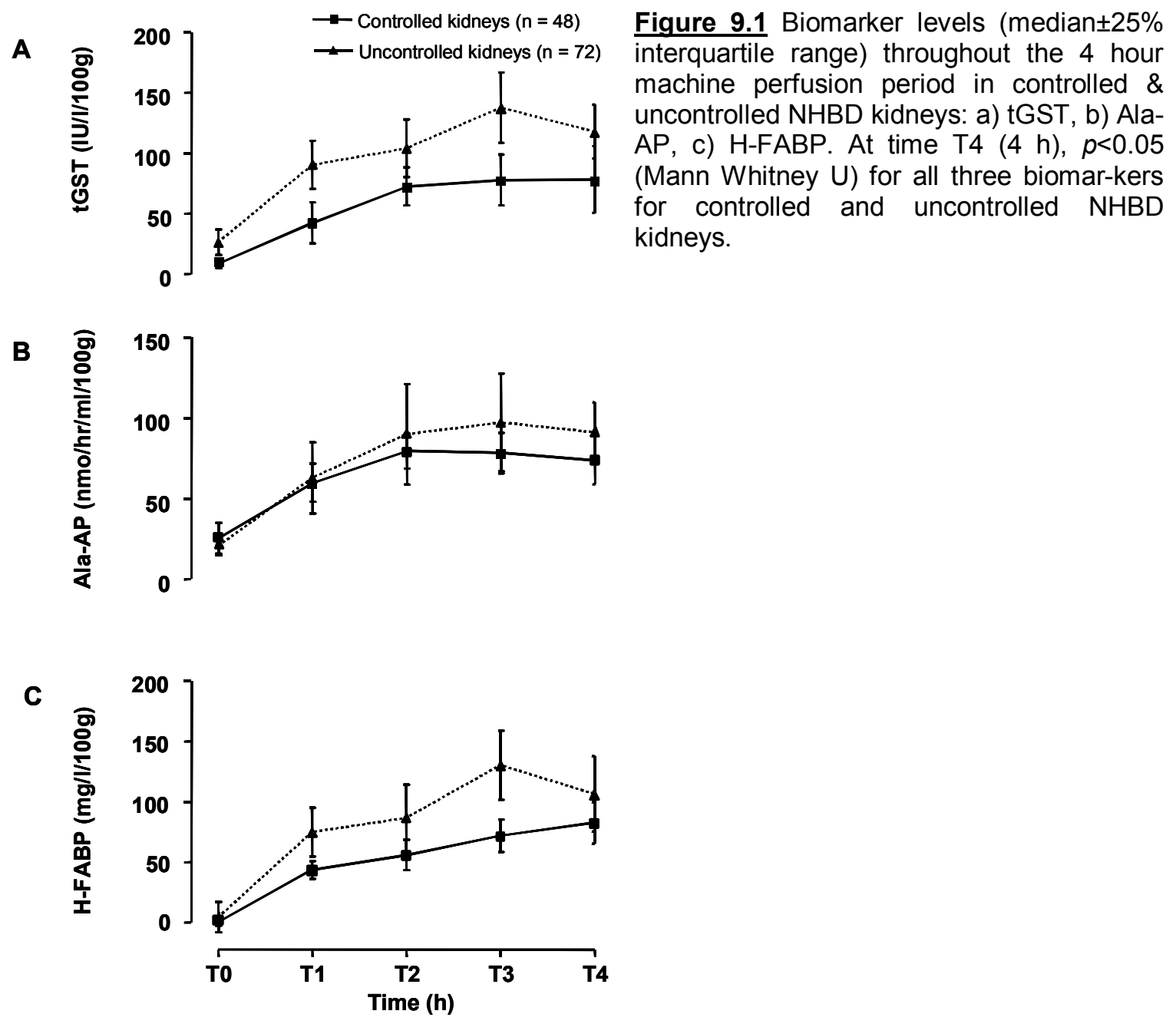

In terms of graft function, renal transplants of uncontrolled donors produced a PNF rate of $13 \%$ and DGF rate of $87 \%$, whereas renal transplants of controlled donors produced an immediate function rate of $32 \%$ and DGF of $68 \%$. The mean tGST activity and H-FABP concentration (expressed per $100 \mathrm{~g}$ of kidney tissue) at 4 (4th hour of machine perfusion) for uncontrolled donors were $143 \pm 18 \mathrm{U} / \mathrm{L}$ and $184 \pm 13 \mu \mathrm{g} / \mathrm{L}$, respectively. For controlled donors tGST activity and H-FABP concentration were $96 \pm 14 \mathrm{U} / \mathrm{L}$ and $80 \pm \mu \mathrm{g} / \mathrm{L}$, respectively.

The differential renal ischemic model was illustrated by the fact that uncontrolled donors suffered worse ischemic insult with significantly longer primary WITs (Table 9.2). Clinically, the use of uncontrolled donors was associated with a higher discard rate, poorer graft survival rate, higher PNF and DGF rates and lower IF rates compared with controlled donors (Table 9.2). This was reflected by significantly higher biomarker 
concentrations detected in the kidney perfusate during machine perfusion of uncontrolled donors $(p<0.05)$ (Fig. 9.1).

A

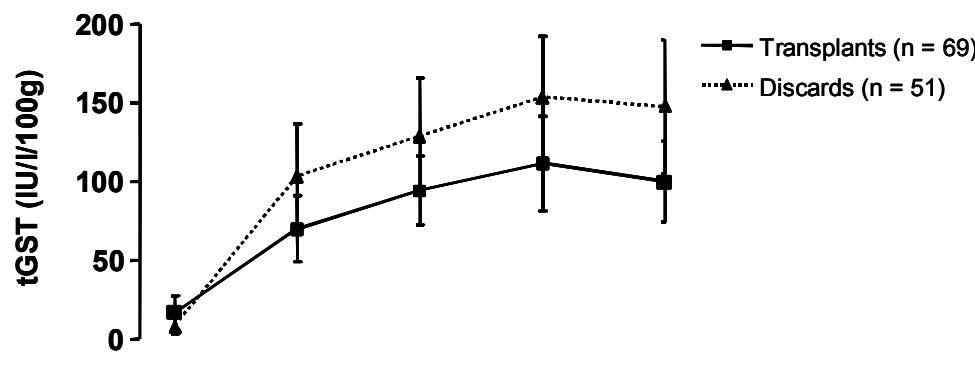

B

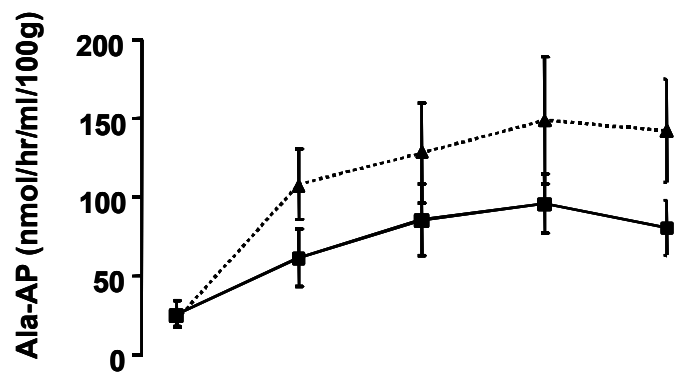

C

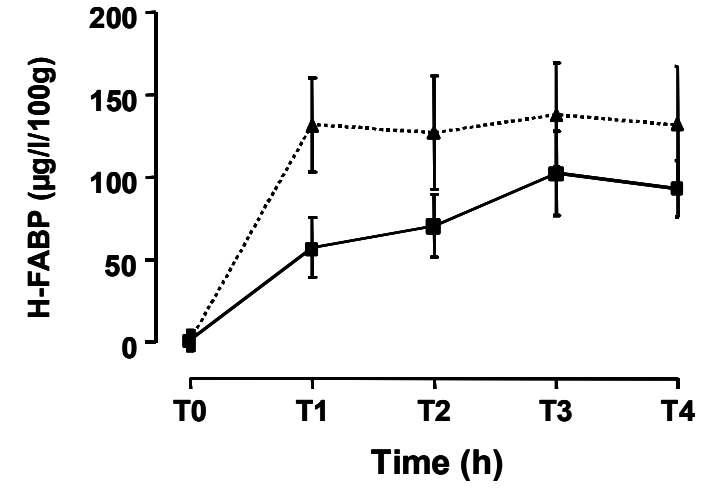

Figure $\quad 9.2$ Biomarker levels (median $\pm 25 \%$ interquartile range) throughout the 4 hour machine perfusion period in transplanted and discarded kidneys: a) tGST, b) AlaAP, c) H-FABP. At time T4 $(4 \mathrm{~h}), \quad \mathrm{p}<0.05 \quad$ (Mann Whitney $U$ ) for all three biomarkers for transplanted and discarded NHBD kidneys.

\subsubsection{Long-term renal function}

The pre-transplant concentration of tGST, Ala-AP and H-FABP did not correlate with subsequent longer term renal function, as assessed by measurement of serum creatinine (tGST: spearman correlation $\mathrm{r}=-0.02$, Ala-AP: $\mathrm{r}=0.02, \mathrm{H}-\mathrm{FABP}: \mathrm{r}=-0.05$ ) and creatinine clearance (tGST: $r=0.08$, Ala-AP: $r=-0.02$, H-FABP: $r=0.14$ ) for those kidneys that had passed their viability tests (Table 9.2). Renal function also showed no correlation with respect to maximum pre-transplant tGST value. 
Chapter 9

Table 9.2 Descriptive demographics results of controlled and uncontrolled donors.

\begin{tabular}{|c|c|c|c|}
\hline NHBD kidneys procured & $\begin{array}{l}\text { Uncontrolled } \\
\qquad(n=75)\end{array}$ & $\begin{array}{c}\text { Controlled } \\
(n=41)\end{array}$ & $\begin{array}{c}\text { Mann-Whitney U-test } \\
\text { (p value) }\end{array}$ \\
\hline $\begin{array}{l}\text { Transplanted } \\
\text { Discarded }\end{array}$ & $\begin{array}{l}34 \\
41\end{array}$ & $\begin{array}{l}40 \\
11\end{array}$ & $<0.0001^{a}$ \\
\hline $\begin{array}{l}\text { Age } \text { (years) }^{\mathrm{b}} \\
\text { Donor } \\
\text { Recipient }\end{array}$ & $\begin{array}{l}50.3 \pm 1.6 \\
49.1 \pm 2.2\end{array}$ & $\begin{array}{l}43.1 \pm 2.8 \\
52.1 \pm 2.4\end{array}$ & $\begin{array}{l}0.07^{\mathrm{a}} \\
0.4^{\mathrm{a}}\end{array}$ \\
\hline $\begin{array}{l}\text { Ischemic time (min) } \\
1^{\text {st }} \text { Warm ischemic time } \\
2^{\text {nd }} \text { Warm ischemic time } \\
\text { Cold ischemic time }\end{array}$ & $\begin{array}{l}24.9 \pm 1.5 \\
38.9 \pm 2.0 \\
1513 \pm 52\end{array}$ & $\begin{array}{l}20.5 \pm 1.5 \\
36.2 \pm 1.2 \\
1468 \pm 54\end{array}$ & $\begin{array}{l}<0.05^{\mathrm{a}} \\
0.4^{\mathrm{a}} \\
0.4^{\mathrm{a}}\end{array}$ \\
\hline $\begin{array}{l}1^{\text {st }} \text { year survival rate }(\%) \\
\text { Kidney } \\
\text { Patient }\end{array}$ & $\begin{array}{l}83.3 \\
82.3\end{array}$ & $\begin{array}{l}96.9 \\
94.1\end{array}$ & $\begin{array}{l}<0.05^{c} \\
0.2^{c}\end{array}$ \\
\hline $\begin{array}{l}\text { Function (\%) } \\
\text { Primary non function } \\
\text { Immediate function } \\
\text { Delayed graft function }\end{array}$ & $\begin{array}{c}13 \\
0 \\
87\end{array}$ & $\begin{array}{c}0 \\
32 \\
68\end{array}$ & $\begin{array}{l}<0.05^{\mathrm{a}} \\
<0.00^{\mathrm{a}} \\
0.07^{\mathrm{a}}\end{array}$ \\
\hline
\end{tabular}

${ }^{a}=$ Chi squared test

${ }^{\mathrm{b}}=$ Mean $\pm \mathrm{SD}$

${ }^{\mathrm{c}}=$ Log-rank $P$ value

A

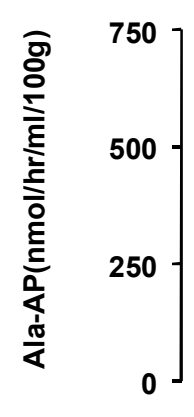

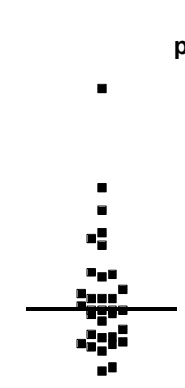

p $<0.05$ Mann Whitney U

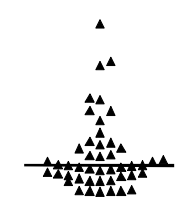

B

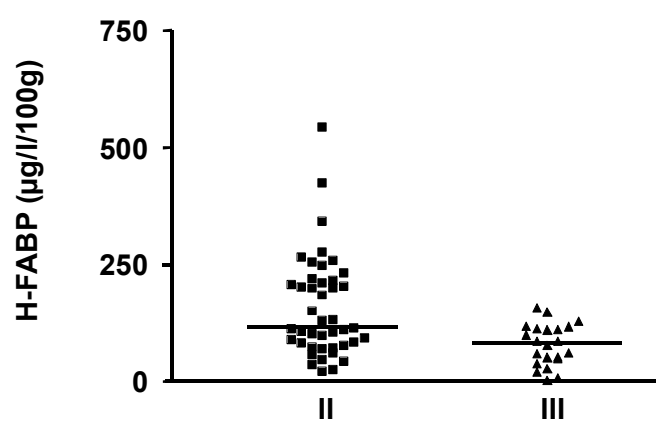

C

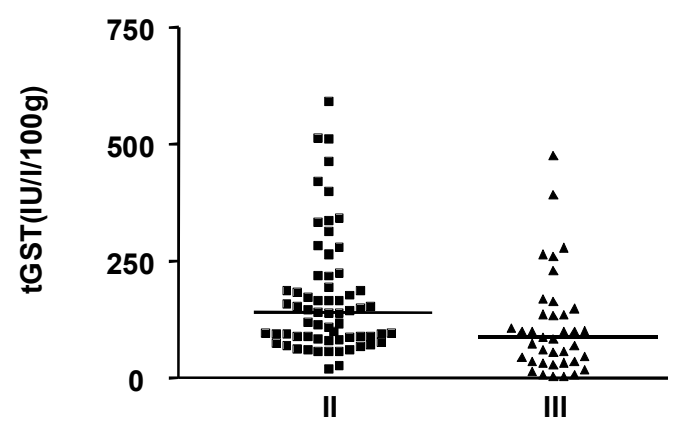

Figure 9.3 Perfusate tGST, Ala-AP, H-FABP levels at time T4 (fourth hour perfusion) in category II and III NHBD kidneys, whether transplanted or discarded (median values outlined): a) AlaAP,b) H-FABP, c) tGST

\subsection{Discussion}

With the increased shortage of suitable donors, there has been a renewed interest in marginal donors. This means that viability testing, which was previously not considered 
essential with NHBDs, is vital. An essential component in viability assessment is the analysis of suitable biochemical markers of tissue injury in machine perfusates pretransplant. During ischemia there is release of cytoplasmic contents of damaged cells into the interstitial and intravascular space. In spite of the use of tGST in machine perfusion as an accepted viability criterion, there is still a 6 to $12 \%$ primary non-function rate in NHBD renal transplants. ${ }^{(24,25)}$ In addition, overcautious disqualification of presumed nonviable kidneys has been estimated to result in a discard rate of 9 to $34 \%$ of total procured NHBD kidneys. ${ }^{(25,26)}$ The rationale for the comparative investigation of tGST, Ala-AP and H-FABP as potential biochemical markers of tissue injury in NHBD kidneys depends on their relative differences in intracellular localization, function and molecular mass, together with the precedent for their use as tissue injury biochemical markers in other disorders as noted above.

A

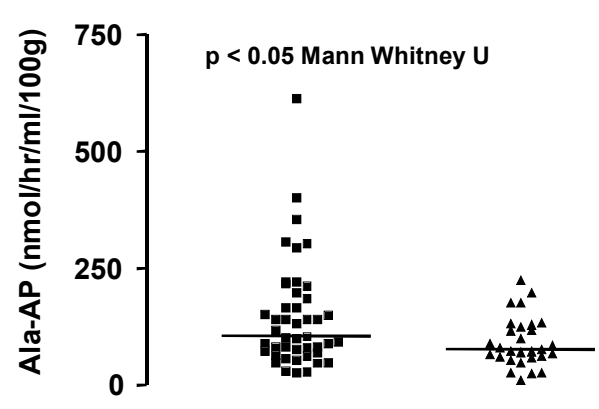

C

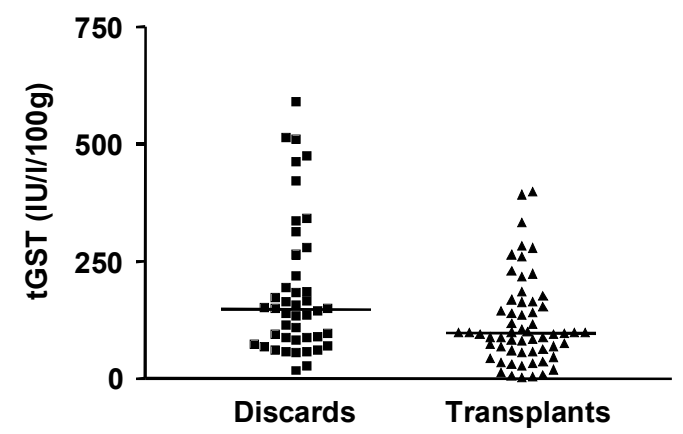

B

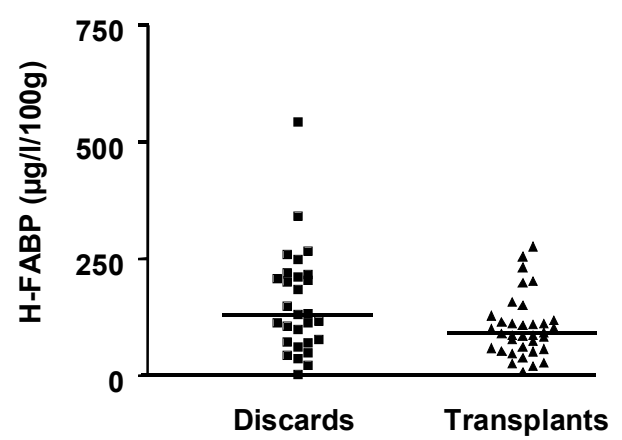

Figure 9.4 Perfusate tGST, Ala-AP, H-FABP levels at time T4 (4th hour of perfusion) in transplanted and discarded kidneys (median values outlined): a) Ala-AP, b) H-FABP, c) tGST

In the present investigation, the activities of tGST (Fig. 9.1a) and Ala-AP (Fig. 9.1b) and the concentration of H-FABP (Fig. 9.1c) showed similar increases in NHBD kidney perfusates over the $4 \mathrm{~h}$ machine perfusion period. The activities of each marker (Fig. 9.2a-c) were similarly raised (at corresponding perfusion time points) in discarded versus transplanted kidneys. Combining all of the above data (i.e., from controlled/uncontrolled categories and transplant/discarded kidneys) revealed a highly significant correlation between corresponding activities of tGST and Ala-AP $(r=0.7859, p<0.0001)$ and of tGST and H-FABP $(r=0.8843, p<0.0001)$. H-FABP shows a better correlation than Ala-AP and this is reflected in the $r$ value (Fig. 9.7). 


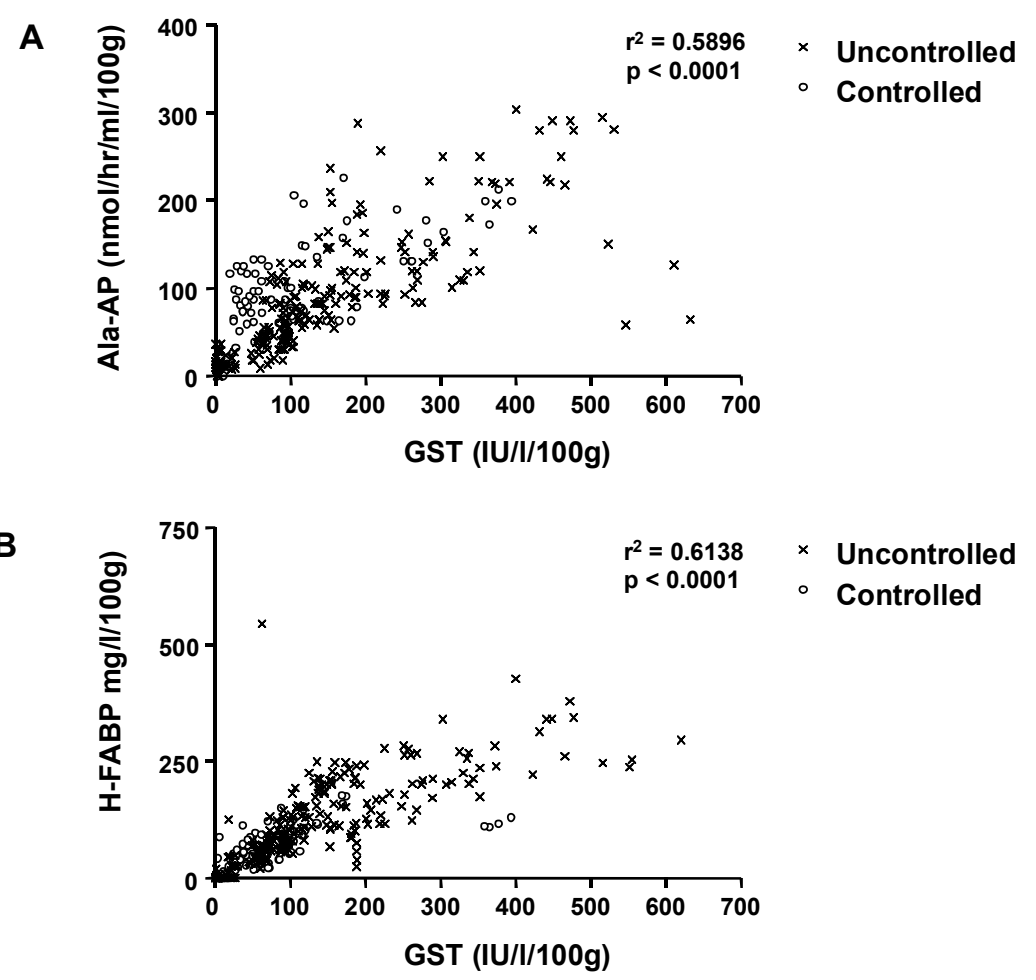

Acute tubular necrosis in renal transplants using NHBDs gives rise to delayed graft function, and this is expressed as reduced renal function at the time of discharge. ${ }^{(27)}$ This is illustrated in the serum creatinine and creatinine clearance at time of discharge and in poorer renal function in renal transplants of uncontrolled donors. However, there is a return to near "normal" function from 3 months post-operatively in both uncontrolled and controlled renal transplants, probably occurring as a result of the selection and use of the most optimal NHBD kidneys. ${ }^{(28,29)}$ Therefore when perfusate biomarkers were correlated to optimal renal function ( $>3$ months post-operatively) there was no correlation to either serum-creatinine nor creatinine clearance.

Our conclusion is that next to donor age, donor medical history, macroscopic appearance, warm ischemic time and ex vivo perfusion, biomarkers like tGST, Ala-AP and H-FABP represent comparable pre-transplant indicators of immediate kidney viability and shortterm kidney-function. Although the biomarkers do not predict the efficacy of renal function in the longer term, the use for short-term screening of kidney function does lead to a survival rate of NHBD kidneys which is sufficient to serve as an important source to match the increasing waiting lists. 

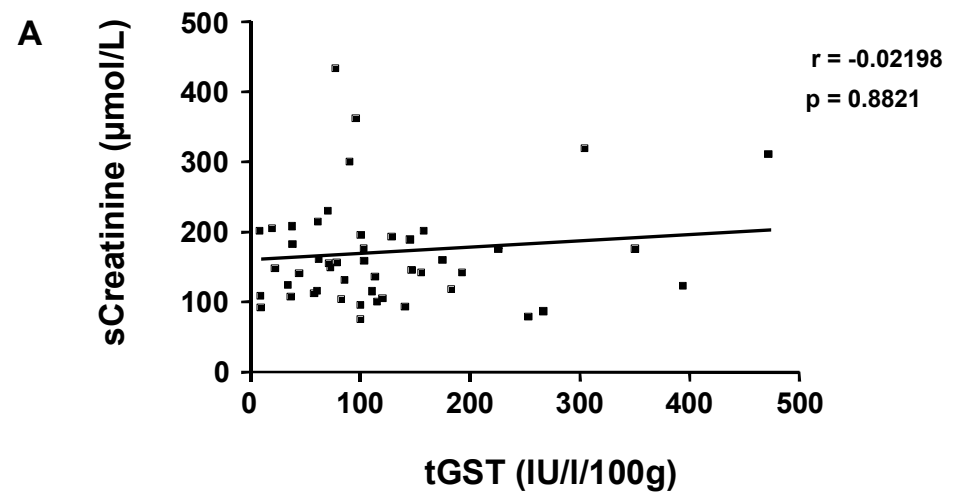

Figure $\quad 9.6$ Scatterlot serum creatinine and biomarkers in kidney effluent: A) tGST, B) Ala$A P, \quad C) \quad H-F A B P \quad(r=S p e a r m a n$ correlation coefficient)

B

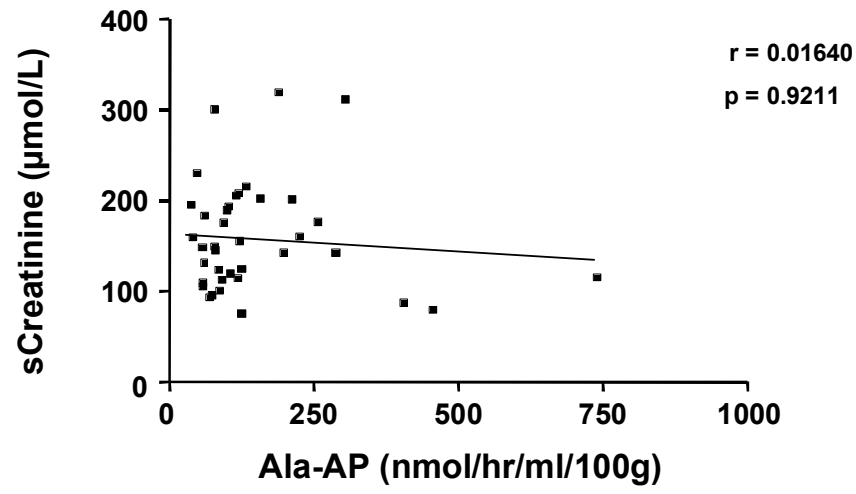

C

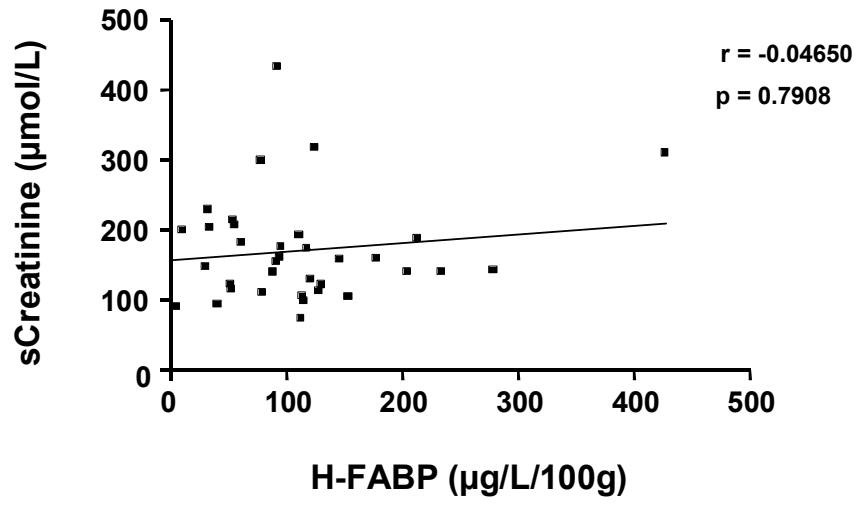

\subsection{References}

1. Terasaki P, Cho Y, Cecka J. Strategy for eliminating the kidney shortage. Clin Transpl 1997:11:265-7.

2. Balupuri S, Buckley P, Snowden C, Mustafa M, Sen B, et al. The trouble with kidneys derived from the non-heart-beating donor: a single center 10-year experience. Transplantation 2000;15:842-6.

3. Kievit J, Oomen A, Janssen M, van Kreel B, Heineman E, et al. Viability assessment of nonheart-beating donor kidneys by alpha glutathione-S-transferase in the machine perfusate. Transplant Proc 1997;29:1381-3.

4. Matteucci E, Carmellini M, Bertoni C, Boldrini E, Mosca F, et al. Urinary excretion rates of multiple renal indicators after kidney transplantation: clinical significance for early graft outcome. Ren Fail 1998;20:325-30. 
5. Glatz JFC, Van der Vusse GJ. Cellular fatty acid-binding proteins: their function and physiological signification. Prog Lipid Res 1996;3:243-82.

6. Holdt-Lehmann B, Lehmann A, Korten G, Nagel H, Nizze H, et al. Diagnostic value of urinary alanine aminopeptidase and $\mathrm{N}$-acetyl-b-D-glucosaminidase in comparison to a1microglobulin as a marker in evaluating tubular dysfunction in glomerulonephritis patients. Clin Chim Acta 2000;297:93-102.

7. Sarvary E, Borka P, Sulyok B, Peter A, Vass Z, et al. Diagnostic value of urinary enzyme determination in renal transplantation. Transpl Int 1996;9:S68-72.

8. Kootstra G, Daemen J, Oomen A. Categories of non-heart-beating donors. Transplant Proc 1995;27:2893-4.

9. Balupuri S, Strong A, Hoernich N, Snowden C, Mohamed M, et al. Machine perfusion for kidneys: how to do it at minimal cost. Transpl Int 2001;14:103-7.

10. Gok M, Shenton B, Strong A, Buckley P, Mohamed M, et al. Pump upgrade for machine perfusion at the Freeman Hospital in Newcastle. Transpl Int 2001;14:207.

11. Strange R, Spiteri M, Ramachandran S, Fryer A. Glutathione-S-transferase family of enzymes. Mutat Res 2001;482:21-6.

12. Feinfeld D, Levine R, Levine S, Fleischner G. Ligandin in perfusates from transplanted kidneys: a test for tubular necrosis. Nephron 1978;21:38-41.

13. Balupuri S, Buckley P, Mohamed M, Cornell C, Mantle D, et al. Assessment of non-heartbeating donor (NHBD) kidneys for viability on machine perfusion. Clin Chem Lab Med 2000;38:1103-6.

14. Habig W, Jakoby W. Assays for differentiation of glutathione-S-transferases. Methods Enzymol 1981;77:398-405.

15. Stange T, Kettmann U, Holzhausen H. Immunoelectron microscopic single and double labelling of aminopeptidase N (CD 13) and dipeptidyl peptidase IV (CD 26). Acta Histochem 1996;98:323-31.

16. Vlahovic P, Stefanovic V. Kidney ectopeptidases. Structure, functions and clinical significance. Pathol Biol 1998;46:779-86.

17. Mantle D, Hardy M, Lauffart B, McDermott J, Smith A, et al. Purification and characterization of the major aminopeptidase from human skeletal muscle. Biochem $J$ 1983;211:567-73.

18. Wodzig K, Kragten J, Hermens W, Glatz J, van Dieijen-Visser M. Estimation of myocardial infarct size from plasma myoglobin or fatty acid-binding protein. Influence of renal function. Eur J Clin Chem Clin Biochem 1997;35:191-8.

19. Yoshimoto K, Tanaka T, Somiya K, Tsuji R, Okamoto F, et al. Human heart-type cytoplasmic fatty acid-binding protein as an indicator of acute myocardial infarction. Heart Vessels 1995;10:304-9.

20. Trimble M, Harrington WJ, Bowman R. Fatty acid transport and metabolism in the isolated perfused rat kidney. Curr Probl Clin Biochem 1977;8:362-70.

21. Maatman R, Van Kuppevelt T, Veerkamp J. Two types of fatty acid-binding protein in human kidney. Isolation, characterization and localization. Biochem J 1991;273:759-66.

22. Wodzig K, Pelsers M, van der Vusse G, Roos W, Glatz J. One-step enzyme-linked immunosorbent assay (ELISA) for plasma fatty acid-binding protein. Ann Clin Biochem 1997;34:263-8.

23. Schreiber A, Specht B, Pelsers M, Glatz J, Borchers T, et al. Recombinant human heart-type fatty acid-binding protein as standard in immunochemical assays. Clin Chem Lab Med 1998;36:283-8.

24. Elwell R, Ward K, James C, Butterworth P, Veitch P, et al. Outcome of referrals to a nonheart-beating kidney retrieval team over a 5-year period. Transplant Proc 1997;29:3549.

25. Shiroki R, Hoshinaga K, Higuchi T, Tsukiashi Y, Kubota Y, et al. Prolonged warm ischemia affects long-term prognosis of kidney transplant allografts from non-heart-beating donors. Transplant Proc 1998;30:111-3. 
26. Alvarez J, Barrio R, Javier A, Ruiz F, Iglesias J, et al. Non-heart-beating donors from the streets. An increasing donor pool source. Transplant 2000;70:314-7.

27. Alonso A, Buitron J, Gomez M, Fernandez GA, Fernandez RC, et al. Short- and long-term results with kidneys from non-heart-beating donors. Transplant Proc 1997;29:1378-80.

28. Gok M, Buckley P, Shenton B, Balupuri S, El-Sheikh M, et al. Long-term renal function in kidneys from non-heart-beating donors: A single-centre experience. Transplant 2002;74: 664-9.

29. van der Sande F, Christiaans M, Kho M, Kievit Y, Kootstra G, et al. Outcome of transplantation of non-heart beating donor kidneys: a single centre experience. The XVII World Congress of The Transplantation Society, Montreal, Canada 1998;Abstracts. 


\section{Liver fatty acid-binding protein as a sensitive serum marker of} acute hepatocellular damage in liver transplant recipients

Part of this chapter is published:

Pelsers MMAL, Morovat A, Alexander GJM, Hermens WT, Trull AK, et al. Liver fatty acid-binding protein as a sensitive serum marker of acute hepatocellular damage in liver transplant recipients. Clin Chem 2002;48:2055-7. 


\subsection{Abstract}

Liver-type fatty acid-binding protein (L-FABP) is a $15 \mathrm{kD}$ protein that is released rapidly from damaged hepatocytes. We evaluated serum L-FABP measurements for the early detection of acute hepatocellular damage associated with acute rejection episodes in a population of liver transplant recipients. The sensitivity of L-FABP was compared with that of the currently used markers alpha glutathione-S-transferase $(\alpha-\mathrm{GST})$ and alanine aminotransferase (ALT). Serum L-FABP and $\alpha$-GST concentrations were measured immunochemically and ALT was assayed enzymatically. A reference range and cut-off value (also termed reference value) for L-FABP in plasma were established in a healthy donor population and showed no age or sex differences. In contrast, a circadian rhythm with elevated nocturnal levels was observed. Routine daily samples from 20 liver transplant recipients who had sustained a total of 21 episodes of acute allograft rejection, were analysed. Acute rejection was diagnosed either histologically or, when liver biopsy was contra-indicated, by general clinical criteria. A significant $(>50 \%)$ increase in serum L-FABP occurred in association with all 21 acute rejection episodes, whereas $\alpha$-GST increased in $20(95 \%)$ and ALT in $16(76 \%)$ episodes. L-FABP increased on average 1.0 day (95\% C.I. $=0.5$ to 1.5 days) earlier than serum ALT and on average 0.3 days $(95 \%$ C.I. $=-0.1$ to 0.6 days) earlier than $\alpha$-GST. L-FABP increased on average 1.5 days $(95 \%$ C.I. $=0.7$ to 2.2 days) earlier than the day treatment was started. L-FABP provides a sensitive means of detecting acute hepatocellular damage with comparable sensitivity as $\alpha$-GST, currently regarded the most sensitive biochemical marker of acute liver injury.

\subsection{Introduction}

Serum tests of acute hepatocellular injury, including ALT and aspartate aminotransferase, are commonly used to investigate the presence, and monitor the progress, of liver disease. $^{(1)}$ The current liver function tests, however, lack sensitivity, and, with the exception of ALT, adequate specificity for liver disease. Although ALT can be measured very quickly and cost-effectively on a routine clinical analyzer, the fact remains that the plasma level of this large protein $(96 \mathrm{kD})$ rises rather late above the reference value after cell injury. The release of cytoplasmic proteins from the damaged hepatocytes into the vascular system follows tissue necrosis caused by e.g., acetaminophen intoxication, ischemia and reperfusion injury, trauma or rejection after transplantation. Because the hepatocytes are in close contact with the vasculature due to wide endothelial clefts and no interstitial barrier, smaller proteins diffuse more rapidly into the circulation than large proteins like with injured cardiomyocytes ${ }^{(2)}$ and would therefore increase earlier in serum above their reference value after acute hepatocellular damage (see Chapter 2.5.1). New specific and sensitive markers of liver injury in general are needed for patient monitoring. ${ }^{(3)}$

Recently, $\alpha$-GST has been introduced as the most sensitive and specific marker of hepatocellular damage currently commercially available. This cytoplasmic $26 \mathrm{kD}$ protein, present in liver, kidney and intestine, is released rapidly from damaged hepatocytes, and has a short in vivo plasma half-life. ${ }^{(4-7)}$ Although not completely hepatocyte specific, it was shown in a randomized trial to look at the clinical benefit, that using $\alpha$-GST for indication of hepatocellular injury due to rejection after liver transplantation, mortality and morbidity decreased due to the more rapid augmentation of immunosuppressive drugs. ${ }^{(5)}$ 
In search of even smaller and more specific cytoplasmic proteins of liver injury, L$\mathrm{FABP}^{(8)}$ may be a promising new marker. L-FABP occurs mainly in the liver, but in small quantities also in kidney and small intestine. ${ }^{(8-11)}$ In healthy male rats, L-FABP is expressed in hepatocytes in a declining portal-to-central gradient in the hepatic lobule. ${ }^{(9)}$ Extensive studies on another type of FABP, namely heart-type FABP (H-FABP), present in heart and skeletal muscle ${ }^{(12,13)}$, show that this protein is rapidly released following myocardial injury, and is regarded as a sensitive marker of myocardial infarction. ${ }^{(13-18)}$ More details are presented in Chapter 2. As the molecular weights of all FABPs are comparable $^{(8)}$, we expect L-FABP to be similar in its diagnostic performance for the rapid detection of liver injury as H-FABP is for cardiac and skeletal muscle injury ${ }^{(12-18)}$ and IFABP for intestinal injury. ${ }^{(19,20)}$ Until now, no studies on human L-FABP release following hepatocellular injury are known.

The aim of this study was to compare serum levels of L-FABP with ALT and $\alpha$-GST for the more rapid detection of hepatocellular injury. For L-FABP, an enzyme-linked immunoassay was developed and optimized. The population of patients chosen was a group of liver transplant recipients who had episodes of acute hepatocellular rejection during their posttransplantation stay in the hospital. Such patients are intensely monitored during their hospitalisation period to control their periods of rejection. ${ }^{(21-25)}$ Acute rejection as final diagnosis is currently based on liver biopsy data. ${ }^{(26)}$ Clinical symptoms like fever, malaise and jaundice as well as liver function tests indicate whether a biopsy has to be taken. ${ }^{(27)}$ As L-FABP has a short in vivo half-life ${ }^{(8)}$ and decreases rapidly with the resolution of hepatocellular injury, it can also be used to study the effect of increased administration (augmentation) of immunosuppressive drugs.

Since renal excretion is the main route of removal of FABPs from the circulation $^{(28)}$, kidney function was assessed by measuring plasma creatinine clearance rates. It is known that renal impairment leads to prolonged elevation in plasma values of $\mathrm{FABP}^{(28)}$ and this can, therefore, underestimate the effect of immunosuppressive drugs. We also measured H-FABP as marker for skeletal muscle injury during surgery. To our knowledge, this is the first study to suggest L-FABP as a promising new biochemical marker for the early detection of hepatocellular injury.

\subsection{Materials and methods}

\subsubsection{Serum samples: Patient group}

Twenty-one liver transplant recipients (15 males, 6 females) were monitored for a period of up to 3 months after transplantation. Daily serum samples from these patients (median 15,5; range 9 to 25) were routinely obtained (usually in midmorning) up to 3 months and were analysed for L-FABP, $\alpha$-GST and ALT. Rejection episodes were diagnosed either histologically or, when biopsy was contra-indicated $(n=3)$, by previously published clinical criteria based on deteriorating liver function tests, increased prothrombin time and a rise in the peripheral blood eosinophil count. ${ }^{(2)}$ Immunosuppressive therapy consisted of treatment with steroids, azathioprine, and either tacrolimus or cyclosporin A. Of the 21 patients studied, 18 had a liver biopsy and received specific treatment with augmented immunosuppression for biopsy-proven acute hepatocellular rejection, usually in the form of 3 daily doses of $1 \mathrm{~g}$ intravenous methyl-prednisolone. The remaining 3 patients received treatment for acute rejection, but for clinical reasons, were not biopsied in the period immediately before treatment was implicated. 
Based on the imprecision of the liver function tests, above the reference value, an increase of at least $50 \%$ in relation to the previous daily value in serum concentration or activity of L-FABP, $\alpha$-GST and ALT activity was taken to be significant. A correlation between such a significant increase and an acute rejection episode was considered to be present if the increase occurred in the period from 4 days prior to 3 days after either a biopsy-proven episode or the start of treatment for the episode. Changes in serum LFABP, $\alpha$-GST and ALT in association with acute hepatocellular rejection were compared with one another and in relation to the time of the start of specific treatment for rejection.

\subsubsection{Plasma samples: Normal range for circulating L-FABP}

In order to determine the reference range for circulating L-FABP, EDTA plasma samples were obtained, from a subset of 80 (40 males, 40 females) out of 312 donors visiting the blood bank of Liège, Belgium ${ }^{(14)}$ (see Chapter 5$)$. For the assessment of intra-individual biologic variation (Chapter 5), citrated blood samples were taken from young, apparently healthy volunteers (6 male and 6 female; age range 19 to 27 years) recruited from the student population of Maastricht University. Samples were obtained at the following time points in a $24 \mathrm{~h}$ cycle: 09.30, 11.00, 14.00, 17.00, 20.00, 23.00, 03.00, 07.00, 09.30. Samples were immediately centrifuged and the plasma fraction aliquoted and frozen at $80^{\circ} \mathrm{C}$ until use. The study was approved by the medical ethics committee of the University Hospital Maastricht, and all subjects gave informed consent. Although these samples were both from other studies, there were no storage problems (data not shown) as was previously established for H-FABP. ${ }^{(13)}$

\subsubsection{Immunoassay I: L-FABP}

Serum and plasma concentrations of L-FABP were measured with an enzyme-linked immunosorbent assay (ELISA) developed together with HyCult biotechnology (Uden, the Netherlands). No influences of different matrices (like citrate) were observed. Briefly, 96-well microtitre plates were coated with a monoclonal antibody against human LFABP. No cross-reactivity was shown with other types of FABP. To separate wells, 100 $\mu 1$ of either recombinant human L-FABP (range 0 to $20 \mu \mathrm{g} / \mathrm{L}$ ) or plasma/serum samples (diluted at least 5-fold) was added. Following $1 \mathrm{~h}$ incubation, the plates were washed 3 times with phosphate buffered saline/0.1\% BSA/0.05\% Tween-20 (PBT), and $100 \mu 1$ of a biotinilated monoclonal antibody was added to each well. After $1 \mathrm{~h}$ incubation, the plates were washed 3 times and $100 \mu 1$ horseradish peroxidase-conjugated streptavidin was added to each well. The plates were incubated for $1 \mathrm{~h}$, after which they were washed again 3 times, and $100 \mu \mathrm{l}$ tetramethylbenzidine (Lucron Bioproducts, Gennep, The Netherlands) was added to each well. Following a 10 min incubation, the reaction was stopped by the addition of citric acid, and the optical density of each well was measured at $450 \mathrm{~nm}$ by the use of a Titertek Multiscan II spectrophotometer (Labsystems, Helsinki, Finland). All incubations were performed at room temperature. The intra- and inter-assay coefficients of variation (CV) were $<5 \%$ and $<15 \%$ at L-FABP concentrations of 2 and $20 \mu \mathrm{g} / \mathrm{L}$ respectively.

\subsubsection{Immunoassay II: H-FABP}

The serum concentration of H-FABP as marker for skeletal muscle injury was measured with an ELISA obtained from HyCult biotechnology (Uden, the Netherlands) as 
described previously ${ }^{(13)}$ (see Chapter 7). Normal plasma H-FABP value is $1.5 \mu \mathrm{g} / \mathrm{L}$ and the reference value is $6 \mu \mathrm{g} / \mathrm{L} .^{(14)}$ There is no cross-reactivity of the used monoclonals with other types of FABP.

\subsubsection{Immunoassay III: $\alpha-G S T$}

Serum and plasma $\alpha$-GST concentrations were measured by the use of an enzyme immunometric assay kit obtained from Biotrin International, Dublin, Ireland. The interassay coefficients of variation (CV) were $14 \%$ and $5.5 \%$ at $\alpha$-GST concentrations of 7.5 and $25 \mu \mathrm{g} / \mathrm{L}$ respectively. The reference value is $10 \mu \mathrm{g} / \mathrm{L}$.

\subsubsection{Enzymatic assay: ALT}

Serum ALT was measured on a Du Pont Dimension multichannel analyser (Du Pont, Wilmington, DE, USA) according to the manufactures instructions. The CV of the ALT method was less than $12 \%$ at the reference value of $50 \mathrm{IU} / \mathrm{L}$.

\subsubsection{Kinetic assay: Serum creatinine}

Serum creatinine concentrations were measured in a standardized clinical chemistry laboratory via the Jaffe rate method on a Beckman Synchron LX-20 pro, according to the manufacturer's instructions. The creatinine reference value is $120 \mu \mathrm{M}$.

\subsubsection{Statistics}

Mann-Whitney test for unpaired values was used to evaluate significant differences in the healthy donor group for age, sex and circadian rhythm. $p<0.05$ was regarded as significantly different.

\subsection{Results}

\subsubsection{Normal L-FABP concentrations}

The assay is linear from 0 to $4 \mu \mathrm{g} / \mathrm{L}$ and samples need to be diluted at least 5 fold to prevent matrix effects. A frequency plot indicates a Gaussian distribution of the normal L-FABP plasma values (data not shown). The average circulating L-FABP concentration in plasma was $9.46 \pm 3.6 \mu \mathrm{g} / \mathrm{L}$ (mean $\pm \mathrm{SD}$; $95 \%$ confidence interval $4.8-16.9 \mu \mathrm{g} / \mathrm{L}$ ). Figure 10.1a shows the normal values of circulating plasma L-FABP according to sex and age. There were no significant changes in plasma L-FABP concentrations in healthy male or female individuals between 21 and 70 years of age. The circadian variation in circulating L-FABP concentrations is shown in Figure $10.1 \mathrm{~b}$. The mean L-FABP concentration during the $09.30-17.00$ period $(6.9 \pm 2.8 \mu \mathrm{g} / \mathrm{L})$ were $17 \%$ higher $(p<0.01)$ than the LFABP serum concentration obtained in the $17.00-03.00$ period $(5.8 \pm 1.3 \mu \mathrm{g} / \mathrm{L})$. The LFABP concentrations then increase by $82 \%$ during the $03.00-09.30$ period $(10.5 \pm 3.6$ $\mu \mathrm{g} / \mathrm{L})$. From the mean value of $9.46 \mu \mathrm{g} / \mathrm{L}$ and the 97.5 percentile of $16.9 \mu \mathrm{g} / \mathrm{L}$, a useful reference value of $17 \mu \mathrm{g} / \mathrm{L}$ can be calculated so all circadian variations are below this reference value. 


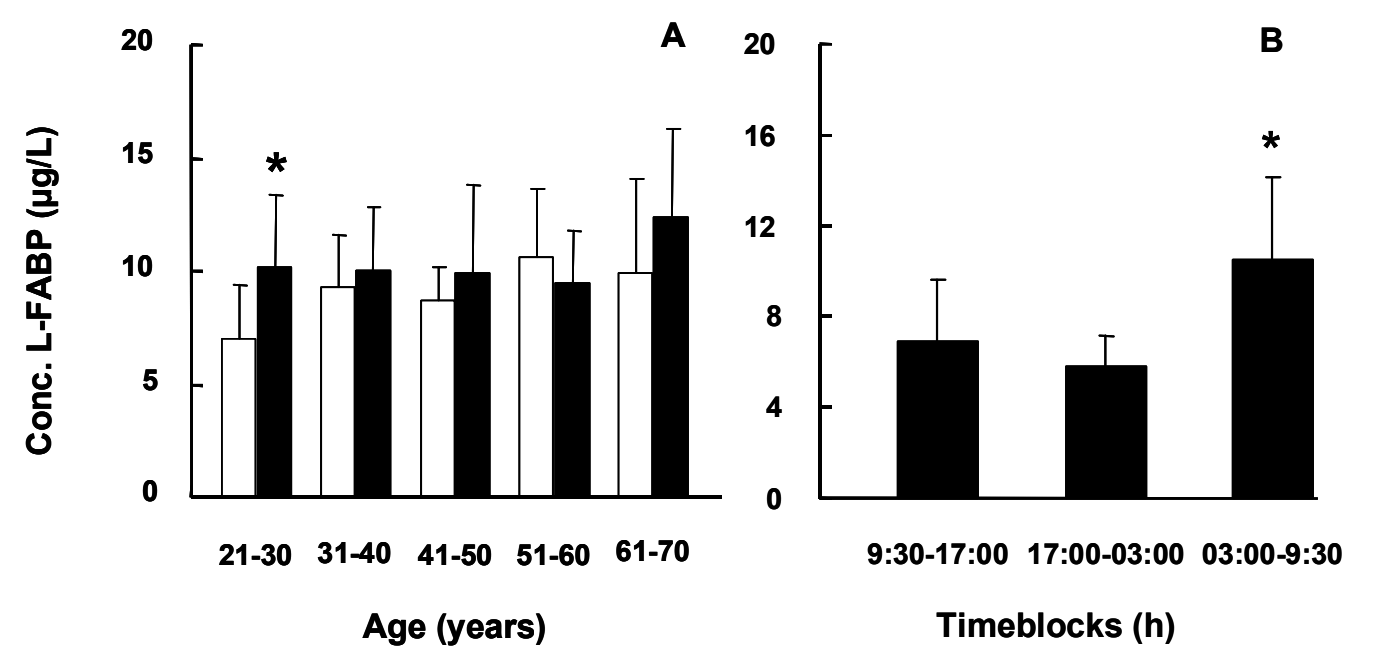

Figure 10.1 A) Normal plasma L-FABP value in different female (white bars)/male (black bars) age groups (each bar represents $n=8$ ). Values are expressed as mean $\pm S D$. B) L-FABP plasma values of healthy young donors (each bar represents $n=6$ ) during different timeblocks $(9.30-17.00$ daytime, 17.00-03.00 evening, 03.00-9.30 night) in the day. ${ }^{*}=p<0.05$

\subsubsection{Liver injury during rejection periods}

Figure 10.2 shows the changes in protein levels of all 3 markers in 4 representative patients. L-FABP and $\alpha$-GST rise earlier than ALT in association with rejection and, due to their short half-life, decrease more rapidly after successful treatment compared with ALT (see Fig. 10.2).

A significant $(>50 \%)$ increase in serum L-FABP occurred in correlation with all 21 acute rejection episodes studied, whereas $\alpha$-GST increased in $20(95 \%)$ and ALT in only $16(76 \%)$ episodes (Fig. 10.3). L-FABP increased on average 1.0 day $(95 \%$ C.I. $=0.5$ to 1.5 days) earlier than serum ALT and on average 0.3 days ( $95 \%$ C.I. $=-0.1$ to 0.6 days) earlier than $\alpha$-GST. L-FABP increased on average 1.5 days ( $95 \%$ C.I. $=0.7$ to 2.2 days) earlier than the day treatment was started. In addition, the magnitude of the increase in serum L-FABP values in association with acute rejection episodes was generally greater than that of $\alpha$-GST. On average, discriminator values (peak serum value/reference value) of L-FABP were 22 while $\alpha$-GST (5.9) and ALT (7.1) were much less. 

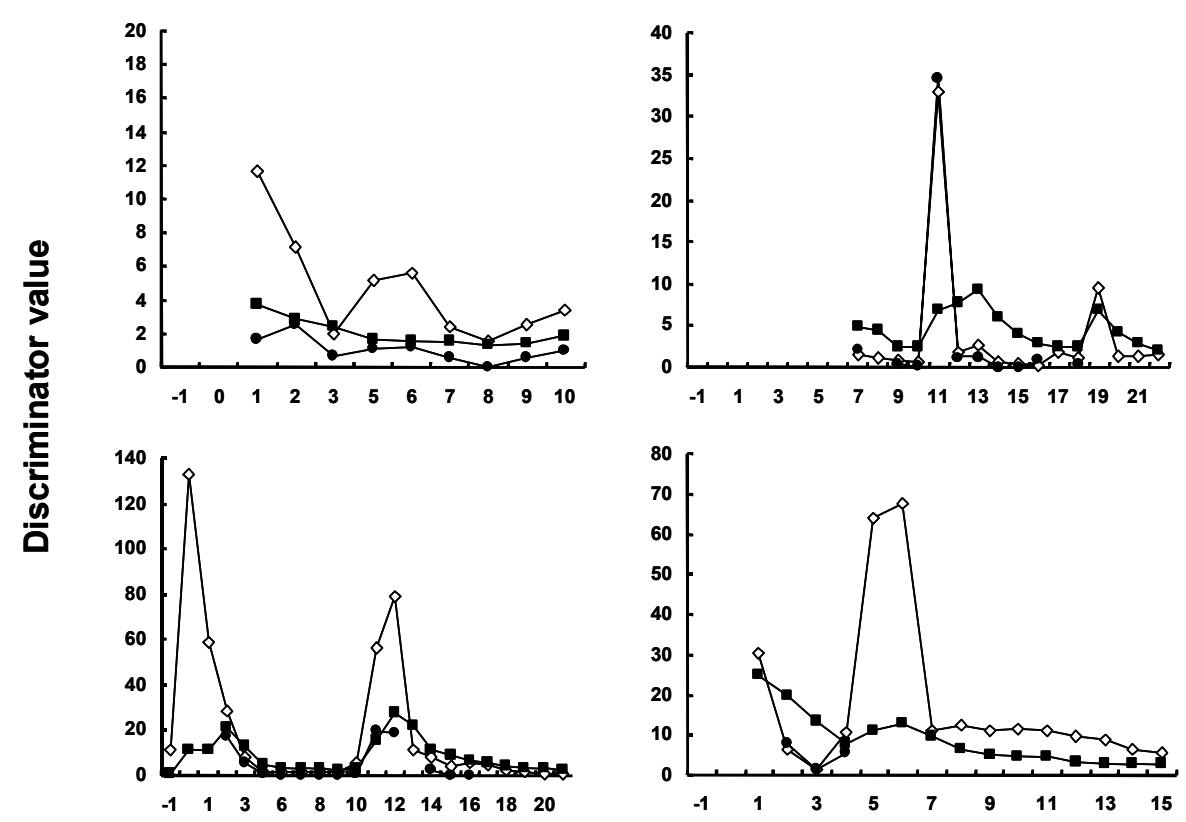

Days after transplantation

Figure 10.2 Protein release after transplantation during 18 days of 4 representative patients. Values are expressed as discriminator value (plasma concentration/reference value) $\diamond=$ L-FABP (reference value $17 \mu \mathrm{g} / \mathrm{L}$ ), $\bullet=\alpha-G S T$ (reference value $10 \mu \mathrm{g} / \mathrm{L}$ ), $\boldsymbol{\bullet}=\mathrm{ALT}$ (reference value $50 \mathrm{U} / \mathrm{L}$ ).

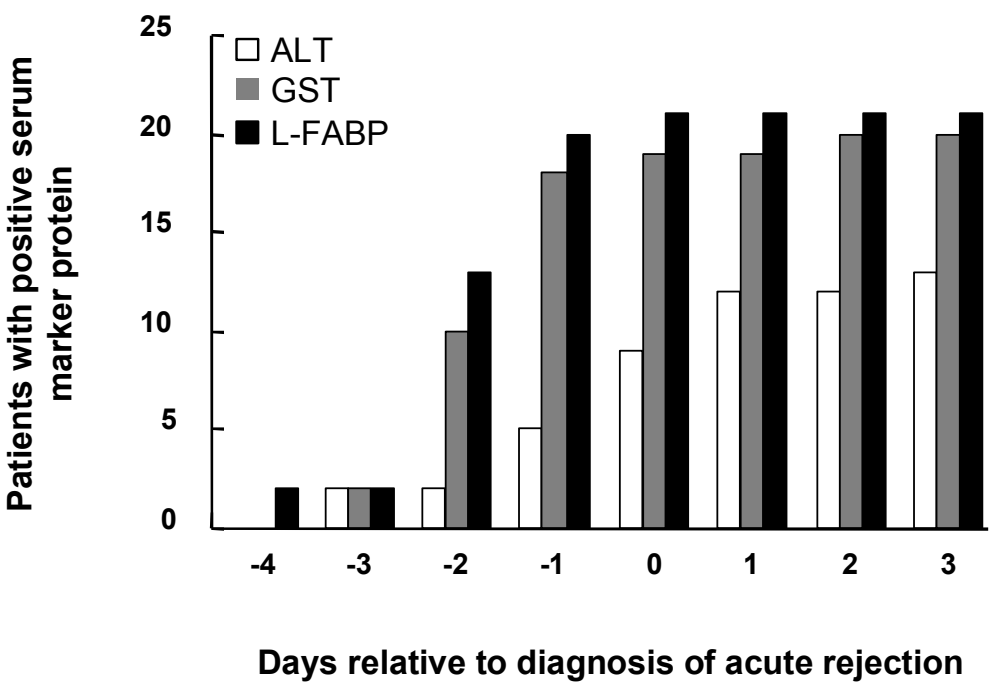

Figure 10.3 Cumulative number of patients with a significant $(>50 \%)$ increase in serum marker protein concentration or activity relative to the day of diagnosis of rejection.

\subsubsection{L-FABP release from damaged allograft}

As the transplanted livers are subject to ischemia/reperfusion injury induced by transplantation of the graft, increased levels of L-FABP can be caused by ischemic injury as well as by rejection injury. Therefore, H-FABP, being a protein capable of detecting skeletal muscle injury but not liver injury, was also measured. In Figure 10.4, the massive 
protein release directly after transplantation in a specific patient is given. Skeletal muscles are injured during surgery and H-FABP is released. L-FABP is released from allograft due to ischemia/reperfusion injury and follows the same clearance pattern as $\mathrm{H}$ FABP up to five days after surgery. No rejection was diagnosed. However, in the biopsy confirmed rejection period (day 5-11), no H-FABP is released, so the L-FABP release during this period is specifically due to rejection of the allograft (Fig. 10.4).

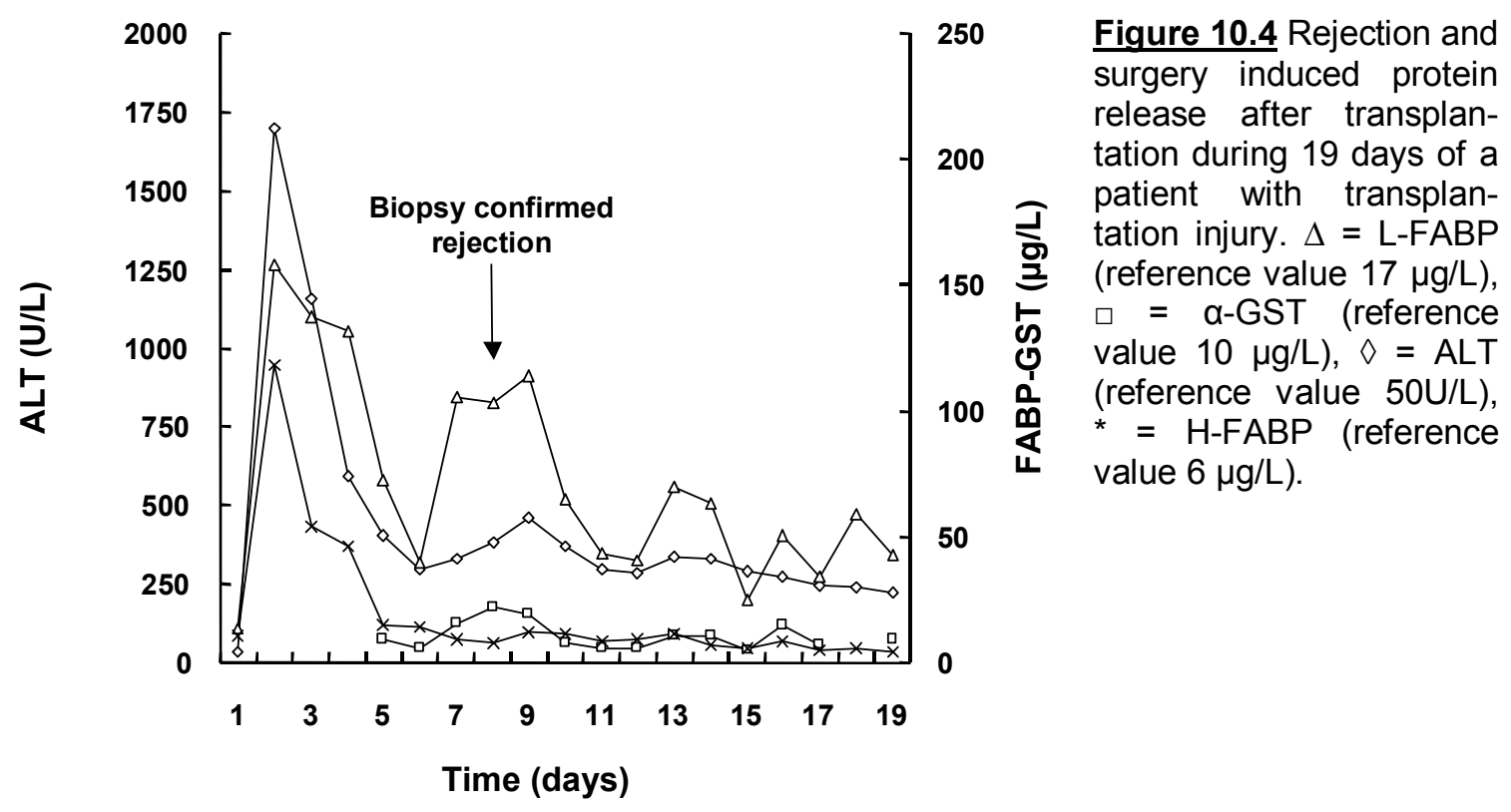

\subsubsection{Renal function}

From the creatinine concentrations measured in all 20 patients of our study group, 4 were above the reference value of $120 \mu \mathrm{M}$, indicating renal impairment as was confirmed by patient end diagnosis. In total 13 patients had decreased creatine clearance rates which can lead to prolonged higher plasma values of L-FABP and $\alpha$-GST.

\subsection{Discussion}

In previous studies we established the heart-type FABP as an early marker for myocardial infarction. ${ }^{(13)}$ Small cytoplasmic FABP is rapidly released into the bloodstream. Due to the low circulating plasma level, FABP rises quickly above the reference value and is therefore very useful for the detection of mild and severe organ injury. Due to the short in vivo half-life, FABP can also be applied to monitor patient treatment. In this study it is shown that after liver injury, the serum L-FABP level increased earlier than $\alpha$-GST above the reference value and can therefore be determined in plasma as the earliest marker of liver injury. In establishing a reference range we found, in contrast to the H-FABP type $^{(14)}$, neither age- nor sex dependent differences in plasma L-FABP values. However, looking at within-day variation it was shown that during the night, plasma L-FABP values increase significantly. This can be explained by the fact that clearance of L-FABP by the kidneys is less during the night as the glomular filtration rate decreases. We have already proven this for H-FABP. ${ }^{(14)}$ Taking the biological variation into account, the reference value $(95 \%$ confidence interval) for liver injury indicated by L-FABP is 
calculated at $17 \mu \mathrm{g} / \mathrm{L}$. The rise in normal plasma values during the night is below this reference value and therefore does not lead to false positive values. Because all patient samples are taken during midmorning, we suspect no influence of the circadian rhythm on the outcome of this study.

After transplantation, patients are monitored for fever, jaundice and malaise. When these symptoms occur, liver function is also tested by the measurement of ALT as routine marker and $\alpha$-GST as it has already shown to decrease mortality and morbidity. ${ }^{(5)}$. We added L-FABP to this spectrum. Biopsies were taken to confirm rejection. Our study reveals that L-FABP rises significantly in all rejection periods and can be detected earlier than $\alpha$-GST and ALT. It is also proven to be earlier increased when the day of treatment is taken as reference. These data are comparable with previous studies of van Nieuwenhoven et al. ${ }^{(2)}$ where they show that small cytoplasmic proteins diffuse earlier into the vascular system after cell injury than large proteins. As L-FABP and $\alpha$-GST are 14 and $26 \mathrm{kD}$ respectively, their release patterns will be rather similar compared to ALT (96 kD), although $\alpha$-GST often appears in it's dimeric isoform of $52 \mathrm{kD}$. However, because of the abundant content of L-FABP in liver tissue, the magnitude of increasement of serum values after liver injury is higher than of $\alpha$-GST and ALT, making L-FABP a more sensitive marker. This sensitivity could even be enhanced as more frequent bloodsampling allows better monitoring of the rise of a serum marker.

As livers are subject to ischemia/reperfusion during the period of donor death, cessation, transport and transplantation, tissue injury will occur. This leads to graft L-FABP detectable in the receiving patient directly after transplantation as seen in patients whose blood was collected directly after surgery. H-FABP was taken as marker for skeletal muscle injury and increased L-FABP serum values directly after transplantation correlated with increased H-FABP levels. The release pattern was similar in the subsequent days indicating only ischemic surgical injury and no rejection, as confirmed by the fact that no biopsies were taken in the first few days after surgery. However, increased L-FABP plasma values during rejection periods (confirmed by biopsy) showed no rise in H-FABP indicating that this is directly related to liver injury and no other trauma. Therefore care must be taken using only biochemical markers directly after transplantation.

Another point is kidney function. Our study shows that 4 transplant recipients had decreased kidney function indicated by creatinine plasma values above the reference value. Due to the decreased clearance rate, proteins are kept prolonged in circulation leading to permanent higher plasma values of the biochemical markers. ${ }^{(28,30)}$ Because LFABP and $\alpha$-GST are normally cleared from the plasma within $24 \mathrm{~h}$ they can be used as markers for the indication of effects of immunosuppressive therapy. When kidney function is decreased the problem might be that immunosuppressive therapy is augmented for a longer period then necessary. This problem could not be studied in our patient population as the amount of blood samples per day was not sufficient to properly investigate the clearance rate of the markers. There is no effect of kidney function on the rise of the marker proteins, only on the clearance rate. Therefore the only effect can be an underestimation of the immunosuppressive treatment.

In conclusion we can state that L-FABP is a new promising marker for detection of hepatocellular injury. Further studies have to be performed to indicate that the use of LFABP can lead to earlier interventions in treatment and better mortality and morbidity rates in liver transplantations. Until now, $\alpha$-GST is not routinely used in assessment of patients in clinical practice because the time of immunological detection is too long for 
starting efficient treatment. Although L-FABP is now available as immunoassay, biosensor developments ${ }^{(31,32)}$ and latextest assays ${ }^{(33)}$ will shorten assay time, reduce labourintensity and costs, leading to a proper use of L-FABP in clinical practice. The use of non-heart-beating-donors is more and more subject of investigation in studies concerning the improvement of allograft availability. ${ }^{(34)}$ As these allografts are even more exposed to ischemia/reperfusion injury, tissue injury markers will gain more and more interest.

\subsection{References}

1. Dufour DR, Lott JA, Nolte FS, Gretch DR, Koff RS, et al. Diagnosis and monitoring of hepatic injury. I. Performance characteristics of laboratory tests. Clin Chem 2000;46;2027-49.

2. Van Nieuwenhoven FA, Musters RJP, Post JA, Verkleij GH, van der Vusse GJ, Glatz JFC. Release of proteins from isolated neonatal rat cardiomyocytes subjected to simulated ischemia or metabolic inhibition is independent of molecular mass. J Mol Cell Cardiol 1996; 28:1429-34.

3. Trull AK. The clinical validation of novel strategies for monitoring transplant recipients. Clin Biochem 2001;34:3-7.

4. Trull AK, Facey SP, Rees GW, Wight DGD, Noble-Jamieson G, et al. Serum $\alpha$-glutathione S-transferase, a sensitive marker of hepatocellular damage associated with liver allograft rejection. Transplant 1994;58:1345-51.

5. Hughes VF, Trull AK, Gimson A, Friend PJ, Jamieson N, et al. Randomized trial to evaluate the clinical benefits of serum $\alpha$-glutathione-s-transferase concentration monitoring after liver transplantation. Transplant 1997;64:1446-52.

6. Becket GJ, Hayles JD. Plasma gluthatione-S-transferase: biomedical applications. Adv Clin Chem 1993;30:281-3.

7. Platz KP, Mueller AR, Haller GW, Müller C, Wenig M, et al. Determination of $\alpha$ - and $\pi$ Gluthatione-S-transferase will improve monitoring after liver transplantation. Transplant proc 1997;29:2827-9.

8. Glatz JFC, Van der Vusse GJ. Cellular fatty acid-binding proteins: their function and physiological signification. Prog Lipid Res 1996;3:243-82.

9. Bass NM, Barker ME, Manning JA, Jones AL, Ockner RK. Acinar heterogeneity of fatty acid-binding protein in the livers of male, female and clofibrate treaded rats. Hepatology 1989;9:12-21.

10. Gordon JI, Alpers DH, Ockner RK, Strauss AW. The nucleotide sequence of rat liver fatty acid-binding protein mRNA. J Biol Chem 1983;258:3356-63.

11. Ockner RK, Manning JA Kane JP. Fatty acid-binding protein. Isolation from rat liver, characterization and immunochemical quantification. Biol Chem 1982;257:7872-8.

12. Van Nieuwenhoven FA, Kleine AH, Wodzig KWH, Hermens WT, Kragten HA, et al. Discrimination between myocardial and skeletal muscle injury by assessment of the plasma ratio of myoglobin over fatty acid-binding protein. Circulation 1995;92:2848-54.

13. Glatz JFC, Van der Voort D, Hermens WT. Fatty acid-binding protein as the earliest available plasma marker of acute myocardial injury. J Clin Lig Ass 2002;25:167-77.

14. Pelsers MMAL, Chapelle JP, Knapen M, Vermeer C, Muijtjens AMM, et al. Influence of age, sex and day-to-day and within-day biological variation on plasma concentrations of fatty acid-binding protein and myoglobin in healthy subjects. Clin Chem 1999;45:441-3.

15. Glatz JF, Kleine AH, van Nieuwenhoven FA, Hermens WT, van Dieijen-Visser MP, et al. Fatty acid-binding protein as a plasma marker for the estimation of myocardial infarct size in humans. Br Heart $J$ 1994:71:135-40.

16. Ishii J, Wang JH, Naruse H, Taga S, Kinoshita M, et al. Serum concentrations of myoglobin vs human heart-type cytoplasmic fatty acid-binding protein in early detection of acute myocardial infarction. Clin Chem 1997;43:1372-8. 
17. Haastrup B, Gill S, Kristensen SR, Jorgensen PJ, Glatz JF, et al. Biochemical markers of ischemia for the early identification of acute myocardial infarction without ST segment elevation. Cardiology 2000;94:254-61.

18. Okamoto F, Sohmiya K, Ohkaru Y, Kawamura K, Asayama K, et al. Human heart-type cytoplasmic fatty acid-binding protein (H-FABP) for the diagnosis of acute myocardial infarction. Clinical evaluation of H-FABP in comparison with myoglobin and creatine kinase isoenzyme MB. Clin Chem Lab 2000;38:231-8.

19. Marks WH, Gollin G. Biochemical detection of small intestinal allograft rejection by elevated circulating levels of serum intestinal fatty acid-binding protein. Surgery 1993;114:206-10.

20. Kanda T, Fujii H, Fujita M, Sakai Y, Ono T, et al. Intestinal fatty acid-binding protein is available for diagnosis of intestinal ischemia: immunochemical analysis of two patients with ischemic intestinal diseases. Gut 1995;36:788-91.

21. Ascher N, Stock PG, Bumgardner GL, Payne WD, Najarian JS. Infection and rejection of primary hepatic transplant in 93 consecutive patients treated with triple immunosuppressive therapy. Surg Gynecol Obstet 1988;167:474-84.

22. Neuhaus P, Bechstein WO, Blumhardt G, Wiens M, Lemmens P, et al. Comparison of quadruple immunosuppression after liver transplantation with ATG or IL-2 receptor antibody. Transplant 1993;55:1320-7.

23. Starzl TE, Todo S, Fung J, Demetris AJ, Venkataremmam R, et al. FK506 for liver, kidney, and pancreas transplantation. Lancet 1989; 2:1000-4.

24. European FK506 Multicentre Liver Study Group. Randomized trial comparing tacrolimus (FK506) and cyclosporin in prevention of liver allograft rejection. Lancet 1994;344:423-8.

25. Neuhaus P, Blumhardt G, Bechstein WO, Platz KP, Jonas S, et al. Comparison of FK506and cyclosporin A-based immunosuppresion in primary orthopic liver transplantation: a single center experience. Transplant 1995;59:31-40.

26. Wight DGD. Pathology of liver transplantation. In: Symmeers WS, ed. Systemic Pathology, Volume 11: Liver, biliary tract and exocrine pancreas. New York: Churchill Livingstone, 1994;543-96.

27. Adams D. Mechanisms of liver allograft rejection in man. Clin Sci 1990;78:343-50.

28. Wodzig KWH, Kragten JA, Hermens WT, Glatz JFC, van Dieijen-Visser MP. Estimation of myocardial infarct size from plasma myoglobin or fatty acid-binding protein. Influence of renal function. Eur J Clin Chem Biochem 1997;35:191-8.

29. Hughes VF, Trull AK, Joshi O, Alexander GJM. Monitoring eosinophil activation and liver function following liver transplantation. Transplant 1998;65:1334-9.

30. De Groot MJ, Wodzig KW, Simoons ML, Glatz JF, Hermens WT. Measurement of myocardial infarct size from plasma fatty acid-binding protein or myoglobin, using individually estimated clearance rates. Cardiovasc Res 1999;44:315-24.

31. Schreiber A, Feldbrügge R, Key G, Glatz JFC, Spener F, et al. An immunosensor based on disposable electrodes for rapid estimation of fatty acid-binding protein, an early marker of myocardial infarction. Biosens Bioelectron 1997;12:1131-7.

32. Key G, Schreiber A, Feldbrügge R, McNeil CJ, Jorgenson P, et al. Multicenter evaluation of an amperometric immunosensor for plasma fatty acid-binding protein: an early marker for acute myocardial infarction. Clin Biochem 1999;32:229-31.

33. Robers M, van der Hulst FF, Fischer MAJG, Roos W, Salud CE, et al. Development of a rapid microparticle-enhanced turbidimetric immunoassay for fatty acid-binding protein in plasma, an early marker of acute myocardial infarction. Clin Chem 1998;44:1564-7.

34. Reich DJ, Munoz SJ, Rothstein KD, Nathan HM, Edwards JM, et al. Controlled non-heart beating-donor liver transplantation. Transplant 2000;70:1159-66. 


\section{Intestinal-type and liver-type fatty acid-binding protein in the intestine: tissue distribution and clinical utility}

Part of this chapter is published:

Pelsers MMAL, Namiot Z, Kisielewski W, Namiot A, Januszkiewicz M, et al. Intestinal-type and liver-type fatty acid-binding protein in the intestine. Tissue distribution and clinical utility. Clin Biochem 2003;36:529-35. 


\subsection{Abstract}

Intestinal-type fatty acid-binding protein (I-FABP) has been proposed as plasma marker for the detection of acute intestinal injury. However, intestinal mucosa also expresses liver-type FABP (L-FABP). We have investigated the tissue distribution of I-FABP and L-FABP in segments of the human intestine along the duodenal to colonal axis and the potential of both proteins to serve as plasma marker for the diagnosis of intestinal injury. FAT/CD36 was measured to compare membrane fatty acid uptake mechanism with the cytoplasmic fatty acid transport proteins. I-FABP, L-FABP and FAT/CD36 were measured with specific immuno-assays in autopsy samples of the intestine (duodenum, jejunum, ileum and colon) of 23 subjects. I-FABP and L-FABP were also measured in plasma samples from patients $(n=51)$ with intestinal and/or hepatic disease. Plasma reference values were established in normal healthy individuals $(n=92)$. The I-FABP tissue contents in duodenum, jejunum, ileum, proximal colon and distal colon amounted to $2.22,4.79,1.04,0.27$ and $0.25 \mu \mathrm{g} / \mathrm{g}$ ww, respectively. L-FABP tissue contents were markedly higher, amounting to 124 and $198 \mu \mathrm{g} / \mathrm{g} w \mathrm{w}$ in duodenum and jejunum, and to 58,26 and $44 \mu \mathrm{g} / \mathrm{g}$ ww in ileum, proximal colon and distal colon, respectively. FAT/ CD36 tissue content showed the same pattern and ranged from 10.4 in duodenum to 20.2, $17.2,5.9$ and $6.6 \mu \mathrm{g} / \mathrm{g}$ ww in jejunum, ileum and proximal and distal colon respectively. Elevated plasma levels of both I-FABP and L-FABP were found in patients suffering from intestinal diseases, while only L-FABP was increased in cases of purely hepatocellular injury. I-FABP, L-FABP and FAT/CD36 show a similar pattern of tissue distribution along the duodenal to colonal axis with highest tissue contents found in the jejunum but in each intestinal segment a $>40$-fold higher content of L-FABP than of IFABP. Accordingly, besides I-FABP, also L-FABP is a useful plasma marker for the detection of intestinal injury, especially in patients undergoing intestinal surgery.

\subsection{Introduction}

The analysis of specific tissue proteins or enzymes in plasma is a common approach for the detection of tissue necrosis and is widely used for detection of liver, muscle and heart injury. ${ }^{(1)}$ However, for the early detection of intestinal injury due to decreased perfusion of the small bowel, inflammation or rejection, no protein is routinely analyzed. Several studies have investigated the use of biochemical markers like hexoaminidase and lactate dehydrogenase $^{(2)}$ or physiological markers like mucosal $\mathrm{pH}^{(3)}$ but these were nonconclusive. By analogy to the use of cytoplasmic heart-type fatty acid-binding protein (H-FABP) for detection of heart- and muscle injury, the cytoplasmic intestinal fatty-acid binding protein (I-FABP) is a proposed marker for the detection of intestinal injury. IFABP occurs in the enterocytes of small intestine and constitutes $2 \%$ of enterocyte protein. ${ }^{(4-6)}$ Several studies have described the use of I-FABP for the detection of rat intestinal injury after acute ischemic diseases ${ }^{(2)}$, rejection ${ }^{(7,8)}$ and necrotic enterocolitis, ${ }^{(9)}$ but with different outcomes in the human setting. ${ }^{(10-18)}$ Furthermore, the tissue content of I-FABP is still unknown, so that plasma I-FABP cannot yet be used for quantification of the amount of tissue injury.

Interestingly, intestinal cells also express liver-type FABP (L-FABP), which occurs in liver and additionally in kidney. ${ }^{(19,20)}$ However, the possibility of using L-FABP and/or a combination of I-FABP and L-FABP as plasma marker for detection of intestinal injury has not yet been explored. When intestinal ischemia is limited to a period of less than $2 \mathrm{~h}$, 
only the villi are affected while the crypt cells remain intact, and there is a rapid recovery of function. ${ }^{(21)}$ Because I-FABP and L-FABP are mainly expressed in the villi and not in the crypt, ${ }^{(4,5,11)}$ we hypothetised that both proteins may be early and sensitive plasma markers of intestinal ischemia.

The aim of our study was to investigate the tissue distribution and contents of both IFABP and L-FABP in human intestine along the duodenal to colonal axis in autopsy samples and to study the potential of these proteins as plasma marker for the detection of intestinal injury in patients. Because the proteins may show a distinct pattern of tissue distribution, expressing their ratio in plasma after intestinal injury might be useful to locate the necrotic stage and improve surgical procedures. Heart-type FABP (H-FABP), which is expressed in smooth muscle cells ${ }^{(2)}$, was measured to investigate whether intestinal autopsy samples are comparable in their amount of muscle cells. FAT/CD36 was measured to evaluate fatty acid uptake in the small intestine and to be compared with L- and I-FABP tissue content. Finally, for establishing a reference value for I-FABP, the influence of age, gender and circadian rhythm on normal plasma concentrations was studied in healthy individuals.

\subsection{Materials and methods}

\subsubsection{Human tissue}

Human intestinal tissue samples were obtained from autopsies of 23 subjects (Medical Academy, Bialystok and Mental Hospital, Choroszcz, Poland), performed at $17 \pm 4 \mathrm{~h}$ after death (mean $\pm \mathrm{SD}$ ), and divided into duodenum, jejunum, ileum, proximal colon and distal colon. The samples then were directly frozen in liquid nitrogen. Human liver tissue, used for investigation of the tissue content of both FABPs, was obtained during routine surgery and after informed consent. Subsequent sample preparations were performed at $4^{\circ} \mathrm{C}$. The studies were approved by the respective local medical ethical committees.

Before analyses, tissues were homogenized (3-16\% w/v) in SET-buffer (0.25 M sucrose, $10 \mathrm{mM}$ EDTA, $10 \mathrm{mM}$ Tris, $\mathrm{pH}$ 7.4) using an Ultra-Turrax homogenizer (IKA Werke, Breisgau, Germany). After sonication, samples were centrifuged (1000 g) and divided into a supernatant fraction (containing the cytoplasmic proteins) and a pellet fraction (containing the membrane located FAT/CD36). Both were stored at $-80^{\circ} \mathrm{C}$ until analyses.

\subsubsection{Plasma samples}

Plasma samples were obtained after informed consent (District Hospital, Bialystok, Poland) from two groups of patients. One group consisted of patients with either severe intestinal injury (due to mesenteric infarction or hernia, $n=5$ ) or with intestinal adhesions $(n=3)$, from whom plasma samples were obtained immediately before and at several days after surgery. The other group consisted of patients with intestinal ischemia $(n=5)$, Crohn's disease $(n=6)$, primary biliary cirrhosis $(n=6)$, obstruction of the extrahepatic biliary tree $(n=5)$, ileus $(n=7)$, acute pancreatitis $(n=5)$, liver damage caused by drugs or alcohol $(n=5)$, or liver carcinoma $(n=4)$, from whom plasma samples were collected once a day starting upon admission and during several days thereafter.

In order to study the influence of age (range 21 to 70 years) and sex on the biological variation of circulating I-FABP and L-FABP, a subset of 80 plasma samples (40 males, 40 females) was obtained from 312 apparently healthy individuals visiting the blood bank 
of Liège, Belgium, as previously described in Chapter $5 .{ }^{(23)}$ For the study of withinperson biological variation (circadian rhythm), blood samples were obtained from young and apparently healthy volunteers (six men and six women; ages 19 to 27 years) recruited from the student population of Maastricht University. Samples were obtained at the following time points: at 9.30, 11.00, 14.00, 17.00, 20.00, 23.00, 00.30, 7.00 and $9.30 \mathrm{~h}$. The study was approved by the medical ethical committee of the Academic Hospital Maastricht and all subjects gave informed consent.

\subsubsection{Immunoassay of FABP types}

Tissue and plasma concentrations of both I-FABP and L-FABP were measured with specific enzyme-linked immunosorbent assays (ELISA) developed in collaboration with HyCult biotechnology (HK 404 and HK 406, Uden, the Netherlands).

Briefly, 96-well microtitre plates were coated with an antibody against either human IFABP (polyclonal) or L-FABP (monoclonal). To separate wells were added $100 \mu 1$ of recombinant human calibrator (I-FABP, range 0 to $5 \mu \mathrm{g} / \mathrm{L}$; L-FABP, range 0 to $20 \mu \mathrm{g} / \mathrm{L}$ ) or tissue/plasma samples (diluted at least 5-fold). Samples were routinely measured in duplicate. Following $1 \mathrm{~h}$ incubation, the plates were washed 4 times, and $100 \mu \mathrm{l}$ of a biotinilated polyclonal- (I-FABP) or monoclonal (L-FABP) antibody was added to each well. After $1 \mathrm{~h}$ incubation, the plates were washed 4 times and $100 \mu \mathrm{l}$ horseradish peroxidase-conjugated streptavidin was added to each well. The plates then were incubated for $1 \mathrm{~h}$, after which they were washed 4 times, and $100 \mu$ tetramethylbenzidine (TMB, Lucron Bioproducts, Gennep, the Netherlands) was added to each well. Finally, following a 10 min incubation, the reaction was stopped by the addition of citric acid, and the optical density of each well was measured at $450 \mathrm{~nm}$ by the use of a Titertek Multiscan II spectrophotometer (Labsystems, Helsinki, Finland). All incubations were performed at room temperature.

H-FABP was measured with a sandwich ELISA obtained from HyCult biotechnology (Uden, the Netherlands) as described in Chapter 3. ${ }^{(24)}$ Normal plasma H-FABP concentration is $1.5 \mu \mathrm{g} / \mathrm{L} .^{(23,24)}$ Using standards of 2 and $12 \mu \mathrm{g} / \mathrm{L}$, the intra- and interassay variations were $<5 \%$ and $<11 \%$. The detection limit of the assay was $0.3 \mu \mathrm{g} / \mathrm{L}$. All three ELISA's are specific for their antigen, because cross-reactivity of the used monoclonals with other types of FABP was $<0.01 \%$. ${ }^{(24)}$

\subsubsection{Immunoassay for FAT/CD36}

For FAT/CD36 measurements, we developed via phage display technology a sandwich ELISA of the antigen-capture type as described previously. ${ }^{(25)}$ Briefly, H9c2 cell line (derived from embryonic rat heart, ATCC, CRL 1446) was used for stable transfection of rat FAT/CD36 (expression vector PSG5-FAT). Before selection, cells were grown to confluency in Dulbeco's modified Eagle's medium (DMEM, Gibco BRL, Life Technologies, Gaithersburg, MD, USA) supplemented with $9 \%(\mathrm{v} / \mathrm{v})$ fetal bovine serum (FBS) (SEBAK, Aidenbach, Germany) and 0.05\% gentamicin under 95\% air $/ 5 \% \mathrm{CO}_{2}$ $\left(\mathrm{H}_{2} \mathrm{O}\right.$ saturated). Northern- and Western blot analysis of 15 cell-lines obtained after transfection confirmed the expression of FAT at RNA and protein level. Two FAT/CD36-cell transfectants were selected: 1A3 showing high levels of FAT/CD36 mRNA expression, and 3B3, showing no measurable FAT/CD36 mRNA expression. ${ }^{(26)}$ Both cell lines show equal growth rates. 
The phage library used in the selections was a subset of the library, with 6 billions clones, as described by Vaughan et al. ${ }^{(27)}$, and was prepared from the naive V-gene pool of the Blymphocytes from 43 non-immunized human donors. After three rounds of selection (each round of selection approximately $2 \times 10^{13}$ phage colony forming units (cfu) were used) on $1 \mathrm{~A} 3$ and $3 \mathrm{~B} 3$, the specificity of the selected phage antibodies was tested on whole cells as well as recombinant proteins, both via ELISA. The diversity of antibody fragments displayed on phage was determined by DNA fingerprint analyses of the antibody scFv fragment inserts as previously described. ${ }^{(28)}$

An ELISA of the antigen capture type (sandwich ELISA) was developed using monoclonal antibody 131.4 (IgG1 type, raised against CD36 purified from human platelets) ${ }^{(29)}$ as catcher and purified phage as detector (Fig. 11.1). Phage antibodies crossreacting with human $\mathrm{CD} 36$ were produced and purified from E.coli TG1. In a polyvinylchloride microtitre plate (Falcon type 3912, Beckton Dickinson, Oxnard, CA), $200 \mathrm{ng} /$ well $\mathrm{mAb} 131.4$ was coated overnight at $4^{\circ} \mathrm{C}$ in $0.1 \mathrm{M}$ sodium bicarbonate buffer ( $\mathrm{pH}$ 9.4). The wells then were rinsed five times with PBS containing $0.1 \%(\mathrm{w} / \mathrm{v})$ BSA and $0.05 \%(\mathrm{v} / \mathrm{v})$ Tween-20 (PBT). Thereafter, wells were blocked for 30 min with 100 $\mu 1 /$ well of $\mathrm{PBS} / 2 \%$ Marvel. Following 5 washing steps with PBT, $100 \mu 1$ standard containing $0-1 \mathrm{mg} / \mathrm{L}$ recombinant 6 -His FAT in $\mathrm{PBS} / 0.4 \%$ Triton $\mathrm{X}-100$ was added per well. Tissue- and cell membrane samples were first diluted $1: 1$ in PBS/4\% Triton X-100 and incubated at $37^{\circ} \mathrm{C}$ for $1 \mathrm{~h}$. After centrifugation for 2 min to remove cell debris, samples were diluted to PBS $/ 0.4 \%$ Triton X-100 and added to the plate $(100 \mu \mathrm{l} / \mathrm{well})$. After incubation for $90 \mathrm{~min}$, wells were washed 5 times with PBT. Then, phage $\left(2 \times 10^{11}\right.$ colony forming units (cfu)/well in PBS/2\% Marvel) were added and incubated for 90 min. After 5 washes with PBT, 1/5000 diluted sheep anti-fd labeled with horseradish peroxidase in $\mathrm{PBS} / 2 \%$ Marvel was added (100 $\mu 1 /$ well). After one hour incubation and 5 washes, plates were developed with $100 \mu \mathrm{TMB} /$ well. The reaction was stopped after 10 min with $50 \mu 15 \% \mathrm{H}_{2} \mathrm{SO}_{4} /$ well and the absorbance was read at $450 \mathrm{~nm}$ using a Titertek Multiscan MkII microplate reader.

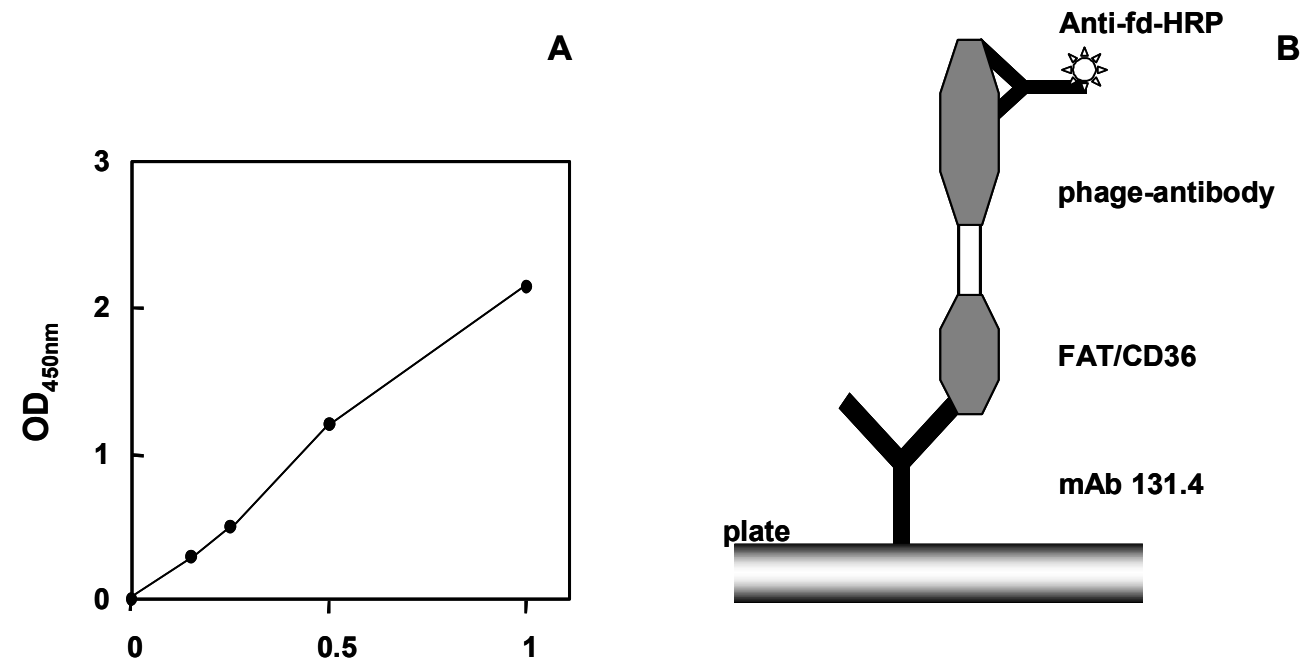

FAT/CD36 mg/L

Figure 11.1 Principle of FAT/CD36 ELISA: A) Calibration curve, B) ELISA setup. 


\subsubsection{Statistics}

Wilcoxon signed ranks test for unpaired values was used to evaluate significant differences in the tissue sections of the small intestine. $p<0.05$ was regarded as significantly different. Data are expressed as median with $25-75$ percentiles.

\subsection{Results}

\subsubsection{I-FABP and L-FABP ELISA}

The sandwich-type ELISAs for I-FABP and L-FABP each showed a detection limit of $0.1 \mu \mathrm{g} / \mathrm{L}$ (measured with standard of $0 \mu \mathrm{g} / \mathrm{L}$; mean+3SD for $\mathrm{n}=10$ ). The calibration curve was linear up to $5 \mu \mathrm{g} / \mathrm{L}$ for I-FABP and up to $20 \mu \mathrm{g} / \mathrm{L}$ for L-FABP. For both assays, using standards of 2 and $5 \mu \mathrm{g} / \mathrm{L}$, the intra-assay and inter-assay coefficients of variation $(\mathrm{CV})$ were $<5 \%$ and $<15 \%$, respectively.

\subsubsection{FAT/CD36 ELISA}

The sandwich-type ELISA for FAT/CD36 showed a detection limit of $50 \mu \mathrm{g} / \mathrm{L}$ (measured with standard of $0 \mu \mathrm{g} / \mathrm{L}$; mean+3SD for $\mathrm{n}=10$ ). The calibration curve was linear from 50 to $1000 \mu \mathrm{g} / \mathrm{L}$. Using standards of 200 and $1000 \mu \mathrm{g} / \mathrm{L}$, the intra-assay and inter-assay coefficients of variation $(\mathrm{CV})$ were $<10 \%$ and $<15 \%$, respectively.

\subsubsection{Intestinal-, liver- and heart-type FABP and FAT/CD36 tissue contents}

The tissue content of I-FABP varies along the small intestine (Fig. 11.2, panel A). Colon contains the lowest amount, i.e., $0.25 \mu \mathrm{g} / \mathrm{g}$ ww $(0.15$ to 0.41$)$. The I-FABP contents of the duodenum, jejunum and ileum are significantly higher than those of colon $(p<0.001)$ with jejunum showing the highest content, amounting to $4.8 \mu \mathrm{g} / \mathrm{g} w \mathrm{w}$ (2.5 to 7.5). I-FABP could not be detected in liver tissue (data not shown).

The tissue content of L-FABP follows a similar pattern along the small intestine, ranging from $26 \mu \mathrm{g} / \mathrm{g}$ ww (14 to 39) in colon to $198 \mu \mathrm{g} / \mathrm{g}$ ww (109 to 383) in jejunum (Fig. 11.2, panel B). The L-FABP contents of the duodenum, jejunum and ileum are significantly higher than those in colon $(p<0.001)$. Liver tissue contains $2.7 \mathrm{mg} / \mathrm{g}$ ww L-FABP. The calculated ratio of L-FABP over I-FABP was found to be not significantly different along the intestinal tract, ranging from 51 in duodenum to 110 in colon (data not shown).

The H-FABP tissue content measured in the small intestine samples shows no significant changes along the small intestinal tract (Fig. 11.2, panel C), indicating comparable amounts of smooth muscle cells in the intestinal tissue samples. The ratio of L-FABP over H-FABP is significantly different $(p<0.05)$ between the duodenum to ileum segment $(29 ; 15$ to 57$)$ and the colon segment $(14 ; 6$ to 19$)$.

FAT/CD36 tissue contents measured in the small intestine samples (Fig. 11.2, panel D) show a similar pattern compared to L-FABP and I-FABP tissue distribution along the duodenal to colonal axis, ranging from $10.4 \mu \mathrm{g} / \mathrm{g}$ ww (3.5 ro 12.8) in duodenum to 20.2 $\mu \mathrm{g} / \mathrm{g}$ ww (7.7 to 30.5 ) in jejunum and $17.2 \mu \mathrm{g} / \mathrm{g}$ ww (6.7 to 30.0$), 5.9 \mu \mathrm{g} / \mathrm{g}$ ww (2.89 to 10.8 ) and $6.6 \mu \mathrm{g} / \mathrm{g}$ ww (3.3 to 12.3 ) in ileum, distal- and proximal colon respectively. 


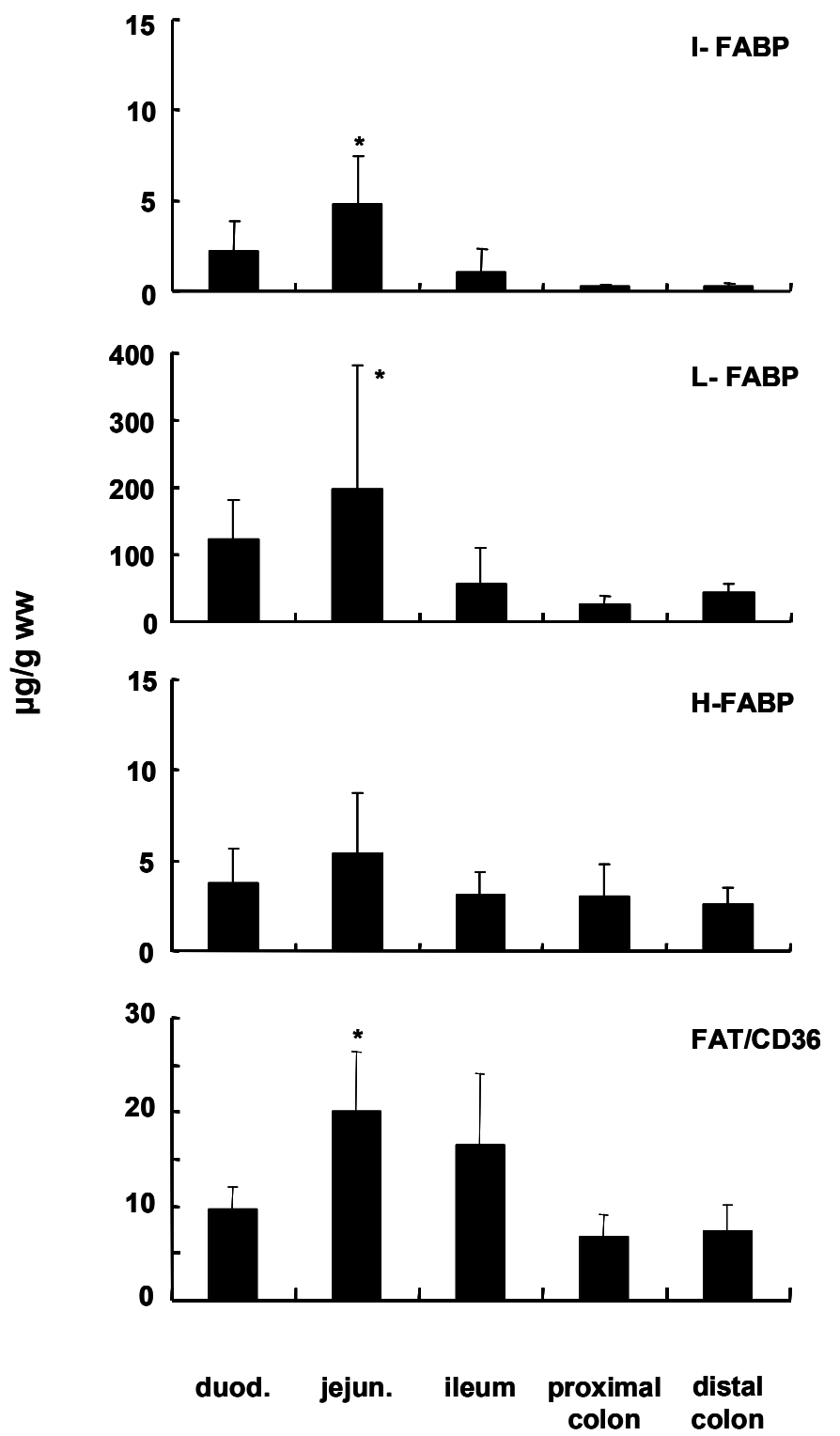

Figure 11.2 Tissue contents of $\mathrm{I}-$ FABP (first panel), L-FABP (second panel), H-FABP (third panel) and FAT/CD36 (fourth panel) in segments of human intestine. Data are median values with $25-75$ percentiles for autopsy samples from 23 subjects. * $=p<0.05$, statistically significant different compared to duodenum.

\subsubsection{Plasma I-FABP and L-FABP reference values}

I-FABP was not detectable in plasma of healthy individuals indicating that the concentration is below the detection limit of the assay $(<0.1 \mu \mathrm{g} / \mathrm{L})$. As a result, the possible influence of age, gender and circadian rhythm could not be assessed. The normal concentration of L-FABP in plasma of healthy individuals was $9.46 \mu \mathrm{g} / \mathrm{L}$ (4.8 to 16.9) and that of H-FABP $1.5 \mu \mathrm{g} / \mathrm{L}$ (1.1 to 2.1 ) and both were not influenced by sex (Table 11.1). We previously reported that during aging plasma $\mathrm{H}-\mathrm{FABP}$ increases slightly but that of L-FABP does not change. ${ }^{(23,30)}$ During the night, plasma L-FABP and H-FABP each were significantly higher than during the day or evening (Table 11.1), most likely due to a decreased glomular filtration rate. ${ }^{(30)}$ This effect already has been noticed for $\mathrm{H}$ FABP plasma concentrations of healthy individuals. ${ }^{(23)}$ L-FABP reference value was 17 $\mu \mathrm{g} / \mathrm{L}$. ${ }^{(30)}$ 
Table 11.1 Influence of sex and circadian rhythm on plasma FABP concentration in apparently healthy individuals.

\begin{tabular}{|l|c|l|l|}
\hline & \multicolumn{3}{|c|}{ Plasma FABP concentration $(\boldsymbol{\mu g} / \mathbf{L})$} \\
\hline & I-FABP & \multicolumn{1}{|c|}{ L-FABP } & H-FABP \\
\hline Men & $<0.1$ & $9.8(8.2-12.1)$ & $1.6(1.3-1.9)$ \\
\hline Women & $<0.1$ & $8.5(7.1-11.1)$ & $1.4(1.0-1.8)$ \\
\hline Daytime (09.30-17.00 h) & $<0.1$ & $6.9(5.0-7.1)$ & $0.8(0.5-1.0)$ \\
\hline Evening (17.00-01.00 h) & $<0.1$ & $5.9(4.8-6.6)$ & $0.9(0.6-1.3)$ \\
\hline Night $\mathbf{( 0 1 . 0 0 - 0 9 . 3 0 ~} \mathbf{~})$ & $<0.1$ & $10.2(7.9-11.7)^{\star}$ & $1.1(0.7-1.5)^{*}$ \\
\hline Reference value & $0.1(10)$ & $17.0(30)$ & $6.0(23)$ \\
\hline
\end{tabular}

The influence of sex was studied in a population 21 to 70 years of age ( $n=40$ for either sex), and that of circadian rhythm in a young population: 19 to 27 years of age $(n=12)$. Values are expressed as median with 25-75 percentiles. I-FABP, intestinal-type FABP; L-FABP, liver-type FABP; H-FABP, heart-type FABP. * Statistically significant from day time and evening samples, $p<0.01$.

\subsubsection{Plasma I-FABP and L-FABP concentrations in disease}

In the group of patients with severe intestinal necrosis, which was confirmed by surgery and due to either mesenteric infarction or hernia, before surgery plasma L-FABP was significantly elevated in all cases, while plasma I-FABP was elevated in 4 out of 5 cases (Fig. 11.3 left and middle panel). In the patients with adhesions, before surgery, I-FABP and L-FABP were slightly elevated in 1 out of 3 cases (Fig. 11.3 right panel). Furthermore, in each of the pre-surgical samples the L-FABP concentration was $>50$-fold higher than that of I-FABP. In the days after surgery, plasma concentrations of both markers dropped markedly. In three cases plasma I-FABP remained below the detection limit of $0.1 \mu \mathrm{g} / \mathrm{L}$.

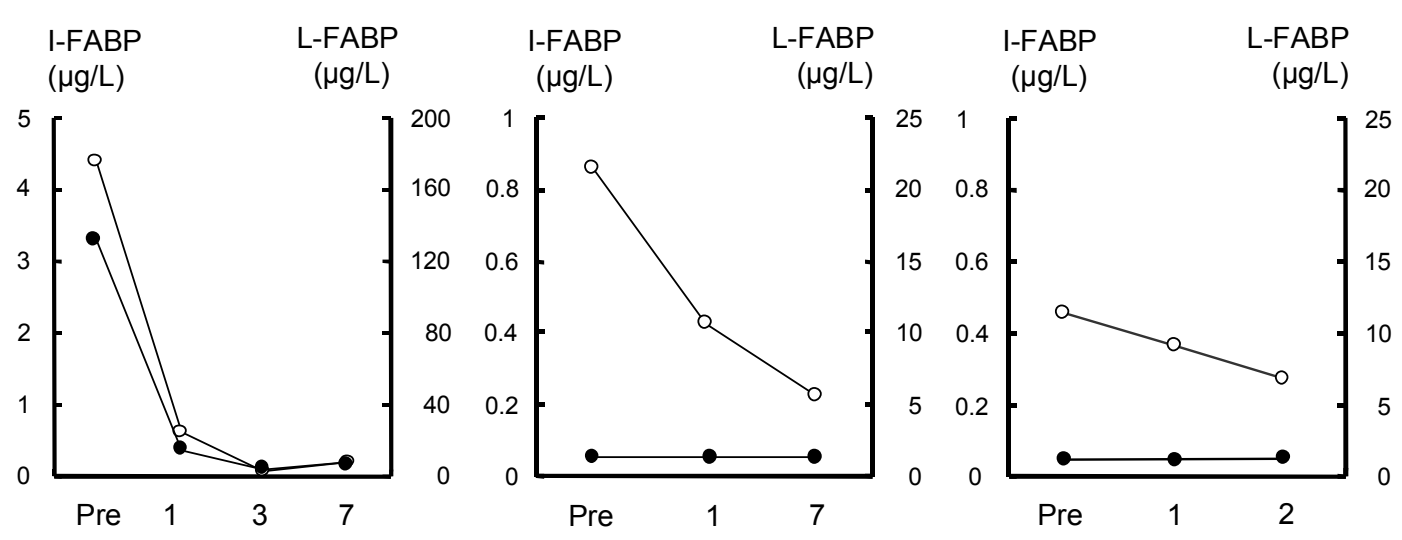

Time after surgery (days)

Figure 11.3 Examples of plasma concentrations of I-FABP $(\bullet)$ and L-FABP $(0)$ in three individual patients, preoperatively (pre) and at different days after surgery. Patients were clinically diagnosed as having ileum necrosis caused by femoral hernia resection (left pane/), small intestine necrosis caused by hernia inguinalis (middle panel), and ileus caused by adhesions (right panel). Note the differences in scale. 
Marked differences were observed among the admission plasma samples obtained from patients with various intestinal and/or hepatic diseases (Fig. 11.4). For this evaluation, a value of $0.1 \mu \mathrm{g} / \mathrm{L}$ was taken as reference value for I-FABP, and $17 \mu \mathrm{g} / \mathrm{L}$ for L-FABP. Elevated plasma levels of I-FABP were observed in 3 out of 5 patients with intestinal ischemia, in 2 out of 6 patients with Crohn disease, in 4 out of 6 patients with primary biliary cirrhosis, in 1 out of 5 patients with obstruction of the extrahepatic biliary tree, and in 2 out of 7 patients with ileus (Fig. 11.4). Plasma L-FABP was elevated in these same patients, and additionally in 9 patients from these groups who showed no increase in I-FABP. Similar results were obtained for the plasma samples obtained from these patients on other days during hospitalization (data not shown).

Acute pancreatitis was associated with elevated plasma L-FABP in 3 out of 5 cases, but no rise in I-FABP (Fig. 11.4). Similarly, liver carcinoma and drug-induced or alcoholinduced liver injury resulted in elevated plasma L-FABP, while I-FABP was increased only in two cases of liver carcinoma.

The ratio of the plasma concentration of L-FABP over that of I-FABP, calculated only for the 13 patients in whom both markers were elevated, was found to show appreciable scatter (range 25 to 500). However, in the cases of intestinal ischemia, Crohn's disease and ileus, the plasma L-FABP over I-FABP ratio was $<100(n=7)$, while in the cases of biliary cirrhosis and liver carcinoma this ratio was $>100(n=6)$.

$\mathrm{H}-\mathrm{FABP}$ was not detectable in plasma of patients with intestinal injury, except for one patient with acute pancreatitis. The localisation of H-FABP in rodent pancreas has been described previously. ${ }^{(31)}$ The ratio of L-FABP over H-FABP for discriminating colon injury to duodenal-ileum segment injury could therefore not be established.

\subsection{Discussion}

This study documents, for the first time, the contents of the cytoplasmic fatty acidbinding proteins I-FABP, L-FABP, and H-FABP in segments of human intestine. In addition, it is shown that in cases of intestinal injury both I-FABP and L-FABP can be found in plasma, whereby the markedly higher intestinal tissue content of L-FABP, when compared to that of I-FABP, is reflected in proportional differences in plasma concentrations of these proteins.

\subsubsection{Distribution of I-FABP, L-FABP and FAT/CD36 in human intestine}

Although several studies already described I-FABP as plasma marker for intestinal injury, ${ }^{(2,7-18)}$ the tissue content of this protein was unknown, and hence the relative amount of injury could not be estimated. This led us to investigate the intestinal content of I-FABP as well as that of L-FABP, which also occurs in this tissue. I-FABP and LFABP were found to show a similar pattern of distribution along the duodenal to colonal axis with highest tissue contents found in the jejunum. This finding coincides with the segmental differences in I-FABP mRNA expression and I-FABP protein distribution as reported for rodents ${ }^{(6)}$, and with the major involvement in dietary fatty acid uptake of the jejunum. ${ }^{(4)}$ FAT/CD36 tissue contents were also for the first time studied in human tissue and confirmed the dietary fatty acid uptake pattern. The pattern was similar to the FAT/CD36 mRNA levels expressed in rat enterocytes of the small intestinal tract ${ }^{(32)}$. 

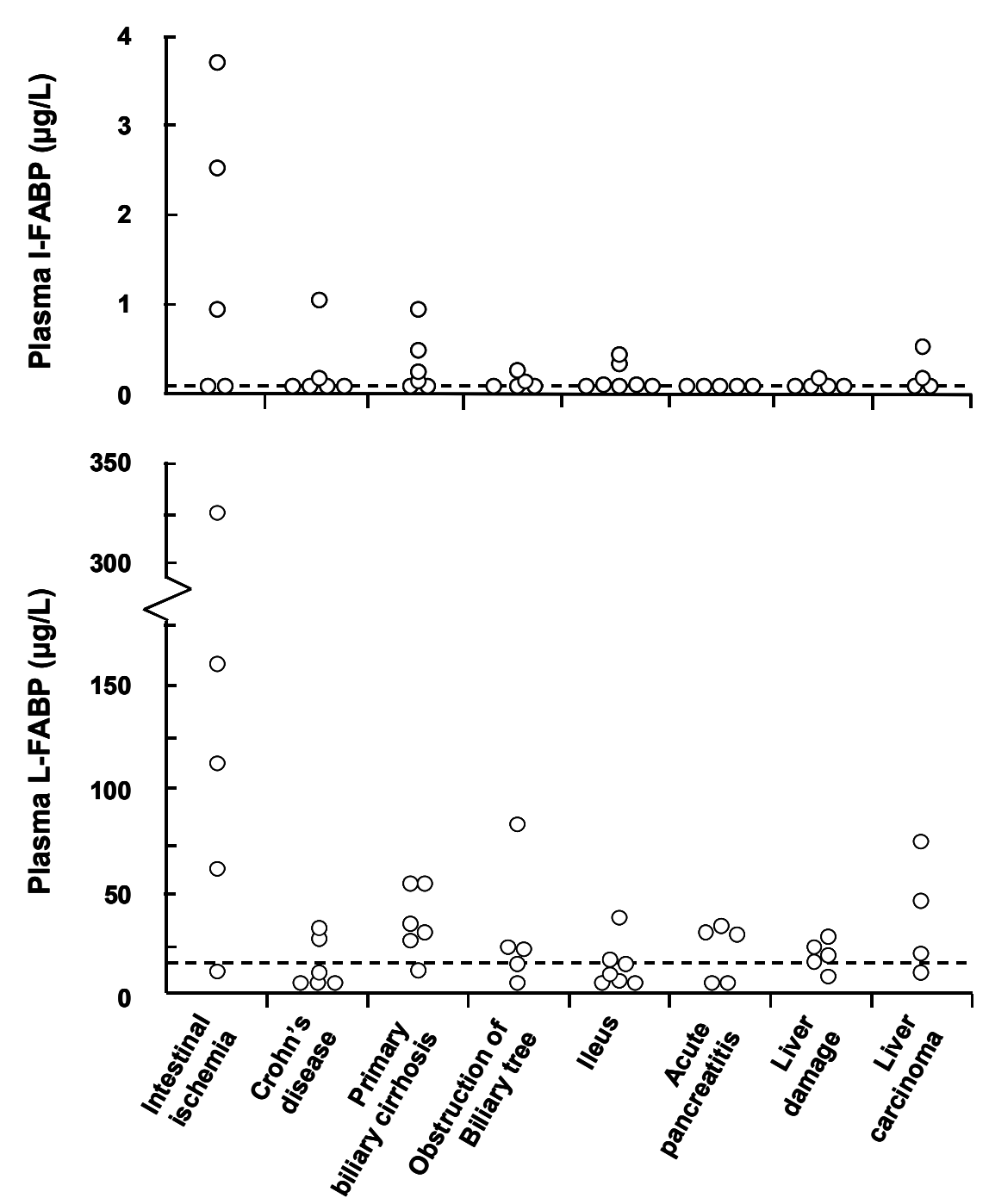

Figure 11.4 Plasma concentrations of I-FABP (upper panel) and L-FABP (lower panel) in 43 individual patients with various intestinal and/or hepatic diseases as measured in the admission blood sample. Dashed lines refer to the reference values of I-FABP $(0.1 \mu \mathrm{g} / \mathrm{L})$ and of L-FABP $(17$ $\mu \mathrm{g} / \mathrm{L})$.

Throughout the intestine the L-FABP tissue content was approximately 40-fold higher than that of I-FABP, so that the ratio of L-FABP over I-FABP could not distinguish among different segments of the intestine. This observation already indicates that for patients with intestinal injury it will be virtually impossible to use the ratio of the plasma concentrations of these proteins for locating the site of injury. However, the ratio of the tissue contents of L-FABP over H-FABP, which latter protein resides in smooth muscle cells $^{(31)}$ and was assayed for comparison, revealed a significantly different value between colon and the small intestine.

\subsubsection{Plasma concentrations of I-FABP and L-FABP in healthy individuals}

Before investigating the utility of I-FABP and L-FABP as potential markers for intestinal injury, a reference range was established using plasma samples from 80 healthy individuals to assess age and sex variation and from 12 healthy young individuals to 
assess circadian variation. Unfortunately, all samples showed an I-FABP concentration below the detection limit of the assay $(<0.1 \mu \mathrm{g} / \mathrm{L})$, so that possible effects on variation of plasma I-FABP could not be documented. This low plasma concentration of I-FABP confirms various previous studies by others ${ }^{(2,7)}$ with the exception of one other study in which a relatively high I-FABP plasma concentration of up to $65 \mu \mathrm{g} / \mathrm{L}$ was reported. ${ }^{(15)}$ Most likely this latter high value relates to different properties of the (recombinant) calibrator of their assay because the reported detection limit of the assay was as high as $20 \mu \mathrm{g} / \mathrm{L}{ }^{(15)}$ A proper comparison of native and recombinant protein may solve this issue. $^{(33)}$ As reported previously, ${ }^{(30)}$ the L-FABP plasma concentration of healthy individuals shows no age nor sex influences, but is susceptible to a circadian rhythm with highest values found during the night. This circadian rhythm is explained by the fact that elimination of FABPs occurs mainly by renal clearance ${ }^{(34)}$ and that the glomular filtration rate decreases during the night. ${ }^{(30)}$

\subsubsection{Clinical utility of I-FABP and L-FABP}

Several previous studies have indicated I-FABP as a promising plasma marker for detecting intestinal injury, although a recent human study reported a lack of utility of plasma I-FABP in predicting intestinal allograft rejection. ${ }^{(18)}$ In a patient population we analyzed retrospectively the utility of plasma I-FABP and L-FABP in different intestinal and hepatocellular diseases. In patients undergoing intestinal surgery, the plasma concentrations of both proteins were highest presurgically and dropped in the days after surgery, which matches with a successful treatment. Importantly, plasma L-FABP was elevated in all 8 patients studied while plasma I-FABP was slightly elevated in only 5 patients. This relates to both the markedly lower tissue content of I-FABP and the detection limit of the assay for I-FABP of $0.1 \mu \mathrm{g} / \mathrm{L}$, and suggests that for perioperative monitoring of patients by L-FABP is more useful than by I-FABP.

When examining admission plasma samples from groups of patients with various diseases, we noticed that, in general, for diseases affecting mainly the intestinal tract (i.e., intestinal ischemia) both I-FABP and L-FABP plasma levels were elevated, while for strictly hepatic diseases (i.e., alcohol induced injury and liver carcinoma) only plasma LFABP was increased. Again, as described above for the surgery patients, in case of intestinal injury plasma L-FABP was elevated in more cases than was plasma I-FABP. Interestingly, when both plasma L-FABP and I-FABP were increased, their ratio could distinguish between purely intestinal injury (L-FABP over I-FABP ratio <100) and intestinal injury combined with liver injury (ratio $>100$ ). Taken together, these preliminary findings suggest that both I-FABP and L-FABP may be suitable plasma markers for diagnosing intestinal injury and that, when both are elevated, these markers allow the discrimination between purely intestinal injury and combined intestinal and liver injuries. Thus, an elevated plasma I-FABP concentration would refer to intestinal injury, but does not exclude liver injury, while an elevated plasma L-FABP concentration may have resulted from either intestinal or liver injury.

\subsubsection{Quantification of intestinal injury}

The availability of the tissue contents of I-FABP and L-FABP in segments of human intestine and the sensitivity of their assays in plasma allows the estimation of the minimal amount of intestinal injury detectable by an elevated plasma FABP concentration. The instantaneous release of the contents of $1 \mathrm{~g}$ tissue $(0.3$ to $5 \mu \mathrm{g}$ I-FABP) into plasma 
would result in a plasma I-FABP concentration between 0.1 and $2 \mu \mathrm{g} / \mathrm{L}$, which is clearly detectable with the immunoassay. However, the half-life time of FABP in plasma is only about $22 \mathrm{~min}^{(35)}$, while the release from tissue may occur more slowly. Nevertheless, we conclude that intestinal injury in the order of magnitude of gram-equivalents of tissue would be detectable. Note that estimation of injury size is hampered by the marked variation in tissue content along the duodenal to colonal axis, i.e., no distinction can be made between a minor injury of the jejunal segment and a larger injury of the colonal segment.

In view of these results, the fact that of the patients with intestinal diseases studied a considerable number showed no elevation of plasma I-FABP (17 out of 29 patients) nor of plasma L-FABP ( 8 out of 29 patients), which finding agrees with reports on I-FABP from other investigators ${ }^{(11,14-18)}$, indicates that not all types of intestinal disease are associated with (a significant degree of) tissue necrosis. In this respect it should be noted that, besides necrosis, cells may also die by classical apoptosis whereby cellular contents are not released into the circulation. In addition, the finding that H-FABP was not elevated in these patients suggests that in intestinal disease the smooth muscle layer surrounding the intestine is hardly or not affected.

\subsubsection{Concluding remarks}

In summary, we have presented preliminary data showing that both I-FABP and L-FABP are potential plasma markers for monitoring intestinal injury and that L-FABP is relatively more sensitive because of a markedly higher intestinal tissue content of this protein. To determine the specificity and sensitivity of these assays a larger study with a prospectively enrolled, non-biased population will be needed. The documented intestinal tissue contents of I-FABP and L-FABP will allow the estimation of intestinal injury size from their release patterns into plasma with time, in analogy to the use of plasma $\mathrm{H}$ FABP for quantification of infarct size following acute myocardial infarction. ${ }^{(34)}$ Future studies should also include more frequent blood sampling so that fluctuations in the plasma concentrations of these proteins can be taken into account. Finally, the introduction of these markers in routine clinical practice will be facilitated by the availability of point-of-care test formats. Rapid detection systems already available for $\mathrm{H}$ FABP, such as a micro-particle enhanced immunoassay ${ }^{(36)}$, an amperometric enzyme immunosensor $^{(37)}$ and a lateral-flow assay ${ }^{(38)}$, illustrate the feasibility of their development.

\subsection{References}

1. Mair J. Progress in myocardial damage detection: new biochemical markers for clinicians. Crit Rev Clin Lab Sci 1997;34:1-66.

2. Gollin G, Marks C, Marks WH. Intestinal fatty acid-binding protein in serum and urine reflects early ischemic injury to the small bowel. Surgery 1993;113:545-51.

3. Andersen LW, Landrow L, Baek L, Jansen E, Baker S. Association between gastric intramucosal $\mathrm{pH}$ and splanchnic endotoxin, antibodies to endotoxin, and tumor necrosis factor alpha concentrations in patients undergoing cardiopulmonary bypass. Crit Care Med 1993;21:210.

4. Glatz JFC, Van der Vusse GJ. Cellular fatty acid-binding proteins: their function and physiological signification. Prog Lipid Res 1996;3:243-282.

5. Ockner RK, Manning JA. Fatty acid-binding protein in small intestine. J Clin Invest 1974;54:326-38. 
6. Sacchettini JC, Hauft SM, Van Camp SL, Cistola DP, Gordon JL. Developmental and structural studies of an intracellular lipid binding protein expressed in the ileal epithelium. $J$ Biol Chem 1990;265:19199-207.

7. Marks WH, Gollin G. Biochemical detection of small intestinal allograft rejection by elevated circulating levels of serum intestinal fatty acid-binding protein. Surgery 1993;114:206-10.

8. Morrisey PE, Gollin G, Marks WH. Small bowel allograft rejection detected by serum intestinal fatty acid-binding protein is reversible. Transplant 1996;61:1451-5.

9. Gollin G, Marks WH. Elevation of circulating intestinal fatty acid-binding protein in luminal contents-initiated model of NEC. J Pediatr Surg 1993;28:367-70.

10. Guthmann F, Börchers T, Wolfrum C, Wustrack T, Bartholomaus S, et al. Plasma concentration of intestinal- and liver FABP in neonates suffering from necrotizing enterocolitis and in healthy preterm neonates. Mol Cell Biochem 2002;239:227-34.

11. Lieberman JM, Sacchettini J, Marks C, Marks WH. Human intestinal fatty acid-binding protein: report of an assay with studies in normal volunteers and intestinal ischemia. Surgery 1997; 121:335-42.

12. Holmes JH, Lieberman JM, Probert CB, Marks WH, Hill ME, et al. Elevated intestinal fatty acid-binding protein and gastrointestinal complications following cardiopulmonary bypass: a preliminary analysis. J Surg Res 2001;100:192-6.

13. Kuo PC, Morris J, Marks WH, Lieberman JM, Johnson DL, et al. Human syngeneic intestinal transplantation: evaluation of enterocyte viability with serum levels of intestinal fatty acidbinding protein. Clin Transplant 1996;10:282-6.

14. Sonnino R, Ereso G, Arcuni J, Franson R. Human intestinal fatty acid-binding protein in peritoneal fluid is a marker of intestinal ischemia. Trans Proc 2000;32:1280.

15. Kanda T, Fujii H, Fujita M, Sakai Y, Ono T, et al. Intestinal fatty acid-binding protein is available for diagnosis of intestinal ischemia: immunochemical analysis of two patients with ischaemic intestinal diseases. Gut 1995;36:788-91.

16. Kanda T, Fujii H, Tani T, Marukami H, Suda T. Intestinal fatty acid-binding protein is a useful diagnostic marker for mesenteric infarction in humans. Gastroenterology 1996;110:339-43.

17. Edelson MB, Sonnino R, Bagwell C, Lieberman J, Marks WH, et al. Plasma intestinal fatty acid-binding protein in neonates with necrotizing entercolitis: a pilot study. J Ped Surg 1999;34:1453-7.

18. Kaufman SS, Lyden ER, Marks WH, Lieberman J, Sudan DL. Lack of utility of intestinal fatty acid-binding protein levels in predicting intestinal allograft rejection. Transplant 2001;71:1058-60.

19. Bass NM, Barker ME, Manning JA, Jones AL, Ockner RK. Acinar heterogeneity of fatty acid binding protein expression in the livers of male, female and clofibrate-treated rats Hepatology 1989;9:12-21.

20. Ockner RK, Manning JA, Kane JP. Fatty acid-binding protein. Isolation from rat liver, characterization and immunochemical quantification. J Biol Chem 1982;257:7872-8.

21. Robinson JW, Mirkovitch V. The recovery of function and microcirculation in small intestinal loops following ischemia. Gut 1972;13:784-9.

22. Van Nieuwenhoven FA, Kleine AH, Wodzig KWH, Hermens WT, Kragten HA, et al. Discrimination between myocardial and skeletal muscle injury by assessment of the plasma ratio of myoglobin over fatty acid-binding protein. Circulation 1995;92:2848-54.

23. Pelsers MMAL, Chapelle JP, Knapen M, Hermens WT, Glatz JFC. Influence of age, sex and day-to-day and within-day biological variation on plasma concentrations of fatty acid-binding protein and myoglobin in healthy subjects. Clin Chem 1999;45:441-3.

24. Wodzig KWH, Pelsers MMAL, Van der Vusse GJ, Roos W, Glatz JFC. One-step enzymelinked immunosorbent assay (ELISA) for plasma fatty acid-binding protein. Ann Clin Biochem 1997;34:263-8.

25. Pelsers MM, Lutgerink JT, Nieuwenhoven FA, Tandon NN, van der Vusse GJ, et al. A sensitive immunoassay for fatty acid translocase (CD36) using phage antibodies selected on 
cell transfectants: abundant presence of FAT/CD36 in cardiac and red skeletal muscle and upregulation in diabetis. Biochem $J$ 1999;3:407-14.

26. Van Nieuwenhoven FA, Luiken JFP, De Jong YF, Grimaldi PA, van der Vusse GJ, Glatz JFC. Stable transfection of fatty acid translocase (CD36) in a rat heart muscle cell line (H9c2) J Lipid Res 1998;39:2039-47.

27. Vaughan TJ, Williams AJ, Pritchard K., Osbourn JK., Pope AR, et al. Human antibodies with sub-nanomolar affinities isolated from a large non-immunized phage display library Nat. Biotechnol 1996;14: 309-14.

28. Marks JD, Hoogenboom HR, Bonnert TP, McCafferty J, Griffiths AD, Winter G. By-passing immunization. Human antibodies from V-gene libraries displayed on phage. $J$ Mol Biol 1991;222:581-97.

29. Matsuno K, Diaz-Ricart M. Montgomery RR, Aster RH, Jamieson GA, Tandon NN. Inhibition of platelet adhesion to collagen by monoclonal anti-CD36 antibodies $\mathrm{Br} \mathrm{J}$ Haematol 1996;92:960-67.

30. Pelsers MMAL, Morovat A, Alexander GJM, Hermens WT, Trull AK, et al. Liver fatty acidbinding protein as a sensitive serum marker of acute hepatocellular damage in liver transplant recipients. Clin Chem 2002;48:2055-7.

31. Watanabe $M$, Ono $T$, Kondo $H$. Immunohistochemical studies on the localisation and ontogeny of heart fatty acid-binding protein in the rat. J Anat 1991;174:81-95.

32. Chen M, Yingkui Y, Braunstein E, Georgeson KE, Harmon MH. Gut expression and regulation of FAT/CD36: possible role in fatty acid transport in rat enterocytes. Am J Physiol Endocrinol Metab 2001; 281:E916-23.

33. Schreiber A, Specht B, Pelsers MMAL, Glatz JFC, Börchers T, et al. Recombinant human heart-type fatty acid-binding protein as standard in immunochemical assays. Clin Chem Lab Med 1998;36:283-8.

34. Wodzig KWH, Kragten JA, Hermens WT, Glatz JFC, van Dieijen-Visser MP. Estimation of myocardial infarct size from plasma myoglobin or fatty acid-binding protein. Influence of renal function. Eur J Clin Chem Biochem 1997;35:191-8.

35. de Groot MJ, Wodzig KW, Simoons ML, Glatz JF, Hermens WT. Measurement of myocardial infarct size from plasma fatty acid-binding protein, using individually estimated clearance rates. Cardiovasc Res 1999;44:315-24.

36. Robers M, van der Hulst FF, Fischer M, Roos W, Salud CE, et al. Development of a rapid microparticle-enhanced turbidimetric immunoassay for fatty acid-binding protein in plasma, an early marker of acute myocardial infarction. Clin Chem 1998;44:1564-7.

37. Key G, Schreiber A, Feldbrügge R, McNeil CJ, Jorgenson P, et al. Multicenter evaluation of an amperometric immunosensor for plasma fatty acid-binding protein: an early marker for acute myocardial infarction. Clin Biochem 1999;32:229-31.

38. Watanabe T, Ohkubo Y, Matsuoka H, Kimura H, Sakai Y, et al. Development of a simple whole blood panel test for detection of human heart-type fatty acid-binding protein. Clin Biochem 2001;34:257-63. 


\section{Brain-type and heart-type fatty acid-binding proteins in the brain; tissue distribution and clinical utility.}

Part of this chapter will be published:

Pelsers M, Hanhoff T, van der Voort D, Arts B, Peters M, Ponds R, et al. Brain-type and hearttype fatty acid-binding protein in the brain; tissue distribution and clinical utility. Clin Chem, in press. 


\subsection{Abstract}

Detection of brain injury via serum markers is not yet a standard procedure in clinical practice, although several proteins like S100B, neuron specific enolase (NSE), myelin basic protein and glial fibrillary acidic protein show promising results. We have investigated the tissue distribution of B-FABP and H-FABP in segments of the human brain and the potential of either protein to serve as a plasma marker for the diagnosis of brain injury. B-FABP and H-FABP were measured immunochemically in autopsy samples of the brain $(n=6)$, and in serum samples from (i) patients with mild traumatic brain injury (MTBI, $\mathrm{n}=130$ ), and (ii) depressed patients undergoing bilateral electroconvulsive therapy $(\mathrm{ECT}, \mathrm{n}=14)$. The marker proteins $\mathrm{S} 100 \mathrm{~B}$ and NSE were measured for comparison. Reference values of B-FABP and H-FABP were established in normal healthy individuals $(n=92)$. Frontal-, temporal-, occipital lobe, striatum, pons and cerebellum showed different tissue contents of B-FABP and of H-FABP. B-FABP tissue content ranged from $0.8 \mu \mathrm{g} / \mathrm{g}$ ww in striatum to $3.1 \mu \mathrm{g} / \mathrm{g}$ ww in frontal lobe. H-FABP tissue contents were markedly higher, ranging from $16.2 \mu \mathrm{g} / \mathrm{g}$ ww in cerebellum to 39.5 $\mu \mathrm{g} / \mathrm{g} w \mathrm{w}$ in pons. No B-FABP was detected in serum of normal healthy donors. H-FABP serum reference value was $6 \mu \mathrm{g} / \mathrm{L}$. In the MTBI study, serum levels of B-FABP were elevated in $68 \%$ and of $\mathrm{H}-\mathrm{FABP}$ in $70 \%$ of the patients, compared to elevated concentrations of S100B in $45 \%$ and of NSE in $51 \%$ of the patients. In ECT, B-FABP serum levels were elevated in $6 \%$ of all samples ( 2 out of 14 patients), while H-FABP was above its reference value of $6 \mu \mathrm{g} / \mathrm{L}$ in $17 \%$ of all samples ( 8 out of 14 patients), and S100B was above its reference level of $0.3 \mu \mathrm{g} / \mathrm{L}$ in $0.4 \%$ of all samples. B-FABP and $\mathrm{H}-$ FABP show a different pattern of tissue content with highest contents found in the frontal lobe and pons, respectively. However, in each part of the brain, the content of H-FABP is at least 10 times higher than that of B-FABP. The patient studies indicate that B-FABP and $\mathrm{H}-\mathrm{FABP}$ are more sensitive markers for minor brain injury than the currently used markers S100B and NSE.

\subsection{Introduction}

Rapid detection of tissue injury is very important for stratifying patient treatment and improved clinical outcome. Therefore, research in the field of brain-specific proteins as biochemical plasma markers for neurological disorders or brain injury is expanding. Protein S100B, NSE, myelin basic protein and the recently introduced glial fibrillary acidic protein are presently being evaluated as marker proteins in cerebrospinal fluid and/or blood for detection of brain injury in neurological patients ${ }^{(1-3)}$, patients with cerebrovascular accidents $^{(4)}$, traumatic brain injury ${ }^{(5)}$, stroke $^{(6)}$, global cerebral ischemia due to cardiac arrest or cardiopulmonary bypass surgery ${ }^{(7,8)}$, tumor cerebri ${ }^{(9)}$ and dementia $^{(10)}$, eventually even to locate the site of injury (neuron, glia or myelin). Although S100B is the most promising marker, conflicting results on elevated S100B serum concentrations after cardiac injury ${ }^{(11.12)}$ indicate that the specificity of this protein is limited.

By analogy to the use of heart-type fatty acid-binding protein (H-FABP) as plasma marker for the rapid detection of cardiac injury ${ }^{(13,14)}$, the FABP types occurring in brain, i.e., brain-type FABP (B-FABP) and H-FABP ${ }^{(15)}$, may be suitable markers for the detection of brain injury. B-FABP and H-FABP are members of a family of nine distinct FABP types, each named after the tissue of its first detection. ${ }^{(16)}$ FABPs are $15 \mathrm{kD}$ 
cytoplasmic non-enzymatic proteins, involved in the intracellular buffering and transport of long chain fatty-acids. FABPs are released rapidly from damaged cells into the circulation and are cleared from the circulation by the kidney with a plasma half-life of 20 min. ${ }^{(14)}$ B-FABP was first identified in the brain of rodents showing a various tissue expression during development. ${ }^{(15,17)}$ In mouse adult stage, B-FABP expression is very weak and only detected in glial cells (presumptive astrocytes) of the white matter. ${ }^{(17-19)}$ Unlike B-FABP, H-FABP is detected in the neurons of the gray matter (neuronal cell bodies) in mouse and rat and constitutes $0.01 \%$ of total brain cytosolic protein. ${ }^{(15,20)}$

The aim of our study was to investigate the tissue distribution and contents of B-FABP and H-FABP in human brain and to study the potential of these proteins as serum marker for the detection of brain injury in patients. Two groups of patients were studied, (i) patients with mild traumatic brain injury (MTBI), and (ii) a controlled study population of depressed patients undergoing bilateral electroconvulsive therapy (ECT). In order to establish an upper reference level for B-FABP, we attempted to measure plasma concentrations in healthy individuals of various age and gender. ${ }^{(21)}$

\subsection{Materials and methods}

\subsubsection{Human brain tissue}

Human brain tissue samples, were obtained during autopsy of 6 subjects ( 5 female, 1 male; age 51-71 y), (Medical Academy, Bialystok, and Mental Hospital, Choroszcz, Poland), and were divided into frontal-lobe, temporal-lobe, and occipital lobe, striatum, pons and cerebellum, and directly frozen in liquid nitrogen. Subsequent sample preparations were performed at $4^{\circ} \mathrm{C}$. The study was approved by the local Medical Ethical Committee and samples were obtained after informed consent of the relatives.

Before analyses, tissues were homogenised (5-16\% w/v) in SET-buffer $(10 \mathrm{mM}$ Tris, $2 \mathrm{mM}$ EDTA, $0.25 \mathrm{M}$ sucrose, $\mathrm{pH}$ 7.4) using an Ultra-Turrax homogenizer $(3 \times 15$ sec at $24.000 \mathrm{rpm}$, with 15-s intervals of cooling on ice, IKA Werke, Breisgau, Germany). After sonication (3 x $15 \mathrm{sec}$, with 15-s intervals of cooling on ice, MSE ultrasonic disintegrator), samples were centrifuged (10 min, $1000 \mathrm{~g}$ ), and the supernatant, containing cytoplasmic proteins, was stored at $-80^{\circ} \mathrm{C}$ until analyses.

\subsubsection{Plasma and serum samples}

Normal healthy controls

In order to determine the biological variation of circulating B-FABP on the reference range, plasma samples (EDTA) were obtained from 80 healthy individuals (40 males, 40 females; age 21-30, 31-40, 41-50, 51-60, 61-70 y; each group $n=8$ ) visiting the blood bank of Liège, to study the influence of age and gender, and from another 12 healthy individuals (citrated plasma; 6 males, 6 females; age 19-27 y,) from the Maastricht University student population to study the influence of circadian rhythm. ${ }^{(21)}$ No difference was observed between plasma or serum. ${ }^{(21)}$

\section{Mild traumatic brain injury (MTBI)}

Patients $(n=130)$ were included in this study when all of the following criteria were met: 1) a blunt blow to the head resulting in post-traumatic amnesia of less than 1 hour; 2) initial loss of consciousness of less than 15 min; 3) Glasgow Coma Scale score $>13$ on presentation at the Emergency Department, and 4) absence of focal neurological signs. 
Approval from the local Medical Ethical Committee review board was obtained prior to the study. During 2 years, all patients presenting with MTBI at the Emergency Department of the University Hospital Maastricht were examined. Duration of posttraumatic amnesia and loss of consciousness were estimated on information from patient and witness. If patients arrived at the Emergency Department within $6 \mathrm{~h}$ following the trauma, and met the criteria for MTBI listed above, informed consent was obtained and blood samples for biochemical marker measurements were taken. Causes of trauma included traffic accidents, accidents in and around the house, accidents at work, sport accidents and battering.

Patients with alcohol abuse were excluded. After clotting, samples were centrifuged at $4000 \mathrm{~g}$ for $20 \mathrm{~min}$ at $4^{\circ} \mathrm{C}$, and after separation from the clot, serum was stored at $-20^{\circ} \mathrm{C}$.

\section{Electroconvulsive therapy (ECT)}

Serum samples $(\mathrm{n}=234)$ were obtained after informed consent (University Hospital Maastricht) from 14 depressed patients undergoing bilateral ECT (on average 10 successive treatment sessions, two times a week). Blood samples were taken on different time points (before ECT, and $1 \mathrm{~h}$ and $3 \mathrm{~h}$ after ECT) during these sessions so that a total of 9 to 28 samples were collected per patient. After clotting, samples were centrifuged and serum was stored at $-20^{\circ} \mathrm{C}$.

\subsubsection{Development of a B-FABP immunoassay}

\section{Production of recombinant $B-F A B P$ and antibodies against $B-F A B P$}

Human B-FABP was expressed and purified as described before. ${ }^{(22)}$ For antibody production, rabbits (white New Zealand) were immunized with $300 \mu \mathrm{g}$ purified recombinant B-FABP and boosted every four weeks with $200 \mu \mathrm{g}$ B-FABP. Polyclonal antibodies were purified by affinity chromatography using $\mathrm{CH}$-activated Sepharose 4B (Pharmacia) coupled with purified B-FABP. Specifically bound antibodies were eluted with $10 \mathrm{mM}$ sodium citrate, $20 \mathrm{mM}$ sodium phosphate, $\mathrm{pH} 2.8$, and immediately neutralised with $0.5 \mathrm{M}$ phosphate buffer, $\mathrm{pH}$ 7.4. The antibodies then were dialysed against PBS with $0.02 \%$ sodium azide and stored at $4^{\circ} \mathrm{C}$.

\section{Specificity detection via Western blotting}

To test specificity and cross reactivity of the antibodies used in the ELISA, samples of Band H-FABP (both $1 \mu \mathrm{g}$ and $10 \mu \mathrm{g}$ in each case) were separated on a $13.5 \%$ SDS-PAGE, blotted on a HyBond nitrocellulose membrane (Amersham Biosciences), and immunodecorated with purified polyclonal antibodies against B-FABP and with monoclonal antibodies against H-FABP (67D3 and 66E2, being catcher and detector antibodies, respectively, in the H-FABP ELISA, HyCult biotechnology, Uden, the Netherlands). ${ }^{(23)}$ Secondary antibodies, conjugated to HRP, were employed in a 1:10.000 dilution. For visualization, ECL Western Blotting Detection Reagents (Amersham Biosciences) were used.

\section{Development of an immunoassay for $B-F A B P$}

Purified polyclonal antibodies were either used as catcher antibody (primary) or as detector antibody (secondary). The latter was biotinylated using D-biotinoyl-6amidohexanoic acid $\mathrm{N}$-hydroxysuccinimide ester (Roche) according to manufacturer's instructions. An enzyme-linked immunosorbent assay of the antibody capture type 
(sandwich ELISA) was developed and performed in MaxiSorb microtiter plates (Nunc). All incubations were done at $37^{\circ} \mathrm{C}$ for $1 \mathrm{~h}$ with a total volume of $100 \mu \mathrm{l} /$ well. First, primary antibody $(2.5 \mu \mathrm{g} / \mathrm{ml})$ was coated in $0.1 \mathrm{M}$ sodium carbonate $(\mathrm{pH} 9.6)$. After washing with phosphate buffered saline (PBS, pH 7.4), the wells were blocked with $0.5 \%$ BSA in PBS. After washing with PBS, B-FABP standard and 2-5 fold diluted samples in sample buffer (PBS, 0.5\% BSA, 0.05\% Tween 20) were applied. Following incubation with the secondary biotinylated antibody $(2.5 \mu \mathrm{g} / \mathrm{ml})$, and with streptavidin-peroxidase diluted 1:10.000 in sample buffer, $o$-Phenylendiamine $(1 \mathrm{mg} / \mathrm{ml}$ in $50 \mathrm{mM}$ sodium citrate, $\mathrm{pH}$ 5.0, supplemented with $\left.0.15 \% \mathrm{H}_{2} \mathrm{O}_{2}\right)$ was used as peroxidase substrate $(5-10 \mathrm{~min}$ incubation at room temperature). The reaction was stopped by addition of $1 \mathrm{M} \mathrm{H}_{2} \mathrm{SO}_{4}$, and absorption at $492 \mathrm{~nm}$ with $405 \mathrm{~nm}$ as reference was measured using Microplate Reader MPP 4008 (Mikrotek Laborsysteme). Additionally, specificity testing was performed also with epidermal-type FABP, liver-type FABP and intestinal-type FABP.

\subsubsection{Immunoassay of H-FABP, myoglobin, S100B and NSE}

Tissue and plasma concentrations of H-FABP were measured with a sandwich-type ELISA obtained from HyCult biotechnology (HK 403; Uden, the Netherlands) exactly as described previously. ${ }^{(21,23)}$ Intra- and interassay coefficients of variation were $<12 \%$. In healthy individuals plasma $\mathrm{H}-\mathrm{FABP}$ is $1.5 \mu \mathrm{g} / \mathrm{L}$, while $6 \mu \mathrm{g} / \mathrm{L}$ is taken as clinical cut-off value. $^{(21)}$

Myoglobin was also measured because the ratio of the plasma concentration of myoglobin over that of H-FABP is indicative for skeletal muscle injury. ${ }^{(25,26)}$ Myoglobin was measured with an electro-chemiluminescence immuno assay (ECLIA method, Elecsys $\left.{ }^{\circledR}\right)$. Intra- and inter-assay coefficients of variation were $<10 \%$. In healthy individuals plasma myoglobin is $27 \mu \mathrm{g} / \mathrm{L}$, and $60 \mu \mathrm{g} / \mathrm{L}$ is taken as clinical cut-off value. $^{(21)}$

The S100B protein concentration was measured with use of a commercially available immunoluminometric assay (Lia-mat Sangtec 100, Sangtec Medical, Bromma, Sweden). According to the manufacturer's instructions, this assay distinguishes between the A1 and B subunits of the S100 protein and measures the $\beta$-subunit as detected by the three monoclonal antibodies SMST 12, SMSK 25, and SMSK 28. The $\beta$-subunit of the S100 protein is known to be predominantly expressed $(80-96 \%)$ in human brain. ${ }^{(27,28)}$ Each measurement was performed in duplicate according to the manufacturer's recommendations. As indicated by the manufacturer, the limit of detection of the assay $\left(B_{0}+3 \mathrm{SD}\right)$ was $0.02 \mu \mathrm{g} / \mathrm{L}$, and the within- and between-assay imprecision $(\mathrm{CV})$ was $5.5 \%$ and $10 \%$, respectively, for concentrations of $0.28-4.17 \mu \mathrm{g} / \mathrm{L} ; 0.3 \mu \mathrm{g} / \mathrm{L}$ was taken as clinical cut-off value.

Neuron specific enolase was measured using a commercially available radioimmunoassay (Pharmacia NSE RIA, Pharmacia \& Upjohn, Uppsala Sweden) according to the manufacturer's instructions. Intra- and interassay coefficients of variation were $<7.5 \%$ at $6 \mu \mathrm{g} / \mathrm{L},<4.7 \%$ at $19 \mu \mathrm{g} / \mathrm{L}$ and $<8.4 \%$ at $90 \mu \mathrm{g} / \mathrm{L} ; 10 \mu \mathrm{g} / \mathrm{L}$ was taken as clinical cut-off value.

\subsubsection{Statistics}

Wilcoxon signed ranks test for unpaired values was used to evaluate significant differences among the tissue sections of the brain. $p<0.05$ was regarded as significantly different. All data are expressed as mean $\pm \mathrm{SD}$. 


\subsection{Results}

\subsubsection{B-FABP ELISA}

Western blot analysis showed that the monoclonal anti-H-FABP antibody 67D3, used as catcher in the ELISA, slightly cross reacts with B-FABP (Fig. 12.1). However, no crossreaction with B-FABP was seen with the monoclonal anti H-FABP antibody 66E2, used as detector in the ELISA (Fig. 12.1). In both blots, recombinant H-FABP was added as positive control. B-FABP $(1000 \mu \mathrm{g} / \mathrm{L})$ was also applied in the H-FABP ELISA and was not detectable. The polyclonal anti B-FABP antibodies showed no cross-reaction with human H-FABP (Fig. 12.1). In this blot, recombinant B-FABP was added as positive control. H-FABP $(1000 \mu \mathrm{g} / \mathrm{L})$ was also applied in the B-FABP ELISA and was not detectable. In both ELISAs, no cross-reaction was detectable with liver-type, intestinaltype or epidermal-type FABPs. Therefore, the sandwich-type ELISAs will specifically detect either B-FABP or H-FABP. The B-FABP ELISA showed a detection limit of 5.0 $\mu \mathrm{g} / \mathrm{L}$ (blanc+2SD, $\mathrm{n}=10$ ), and the calibration curve was linear between 10 to $100 \mu \mathrm{g} / \mathrm{L}$. Using calibrators of 20 and $100 \mu \mathrm{g} / \mathrm{L}$, the intra- and inter-assay coefficients of variation (CV), calculated from 10 repetitive measurements, were $<6 \%$ and $<15 \%$, respectively.

\subsubsection{Brain tissue contents of B-FABP and H-FABP}

In each part of human brain studied, the tissue contents of H-FABP were found to be $>10$ fold higher than those of B-FABP (Fig. 12.2). Data are expressed as mean \pm SD. The ratio of H-FABP over B-FABP is only significantly different $(p<0.05)$ in striatum compared to that in frontal lobe and in cerebellum (Fig. 12.2).

\section{Plasma $B-F A B P$ and $H-F A B P$ reference concentrations}

B-FABP was not detectable in plasma of healthy individuals, indicating that the concentration is below $5 \mu \mathrm{g} / \mathrm{L}$ i.e., below the detection limit of the assay. As a result, possible influences of age, gender and circadian rhythm could not be assessed. H-FABP in plasma of normal individuals was $1.5 \mu \mathrm{g} / \mathrm{L}$, as described previously. ${ }^{(21)}$ Plasma $\mathrm{H}-$ FABP was higher during the night than during daytime, due to a decreased glomular filtration rate. Age and gender also slightly influenced the normal range of plasma $\mathrm{H}-$ FABP. ${ }^{(21)}$

\section{Mild traumatic brain injury}

B-FABP serum concentrations were elevated ( $>5 \mu \mathrm{g} / \mathrm{l})$ in 88 out of 130 patients, while $\mathrm{H}-$ FABP levels $(>6 \mu \mathrm{g} / \mathrm{L})$ were elevated in 91 patients (Table 12.1). Protein S100-B serum levels were elevated $(>0.3 \mu \mathrm{g} / \mathrm{l})$ in 59 patients and NSE serum levels $(>10 \mu \mathrm{g} / \mathrm{L})$ in 66 patients. The median (2.5-97.5 percentile) ratio of serum concentrations of H-FABP over B-FABP was $0.58(0.1-8.4)$. B-FABP and H-FABP were both elevated in $45 \%$ of all serum samples, while $23 \%$ showed only elevated H-FABP serum levels and $16 \%$ only elevated B-FABP levels. Both proteins were negative in the remaining $16 \%$ of the serum samples. 


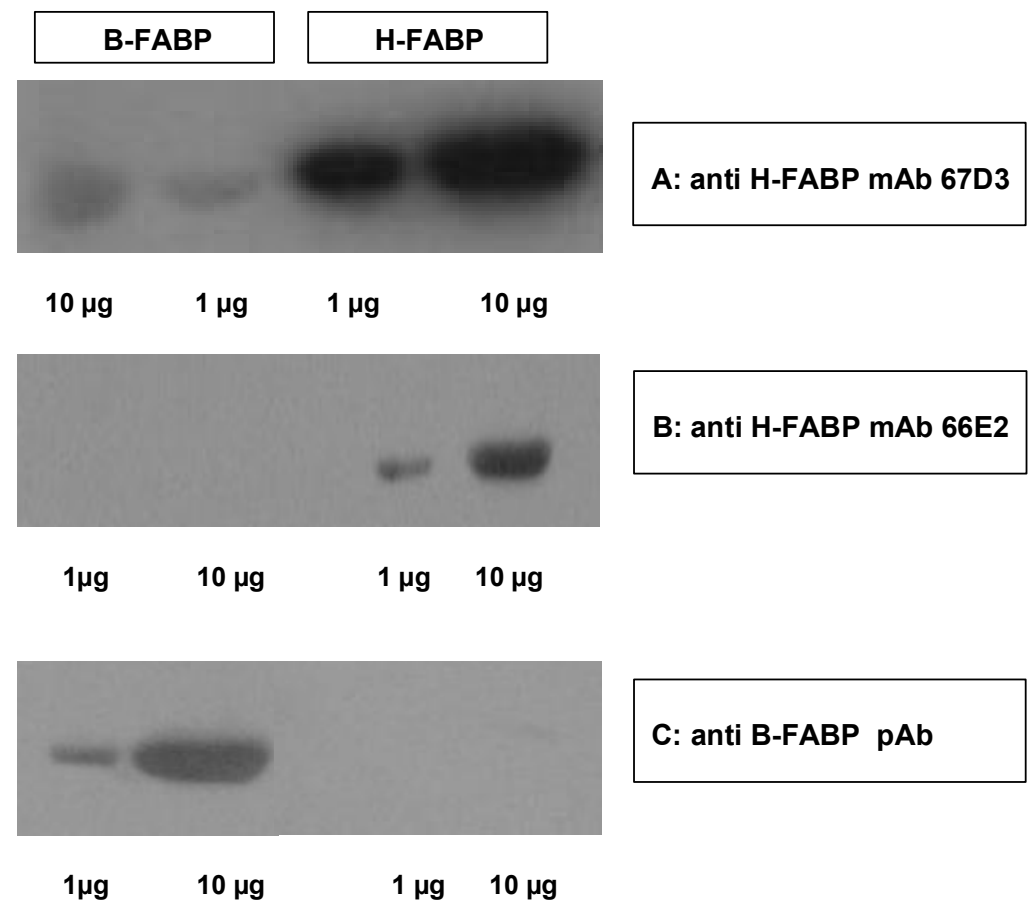

Figure 12.1 Western blot of A) monoclonal anti H-FABP antibody 67D3, B) monoclonal anti H-FABP 66E2 antibody and $C$ ) polyclonal anti B-FABP antibody with recombinant $B$ FABP and H-FABP.

\section{Electroconvulsive therapy}

In all 234 serum samples examined, S100B concentrations were below the reference value of $0.3 \mu \mathrm{g} / \mathrm{L}$ (except for a single sample with an elevated concentration of 0.35 $\mu \mathrm{g} / \mathrm{L})$ (Table 12.2). B-FABP serum concentrations could only be detected ( $>5 \mu \mathrm{g} / \mathrm{L})$ in 15 samples of which 13 were from a single patient. H-FABP serum levels were above reference value of $6 \mu \mathrm{g} / \mathrm{L}$ in 39 samples ( 8 out of 14 patients), in 8 of which B-FABP was also elevated.

In the 39 serum samples with elevated H-FABP, plasma myoglobin was $62.8 \pm 31.8 \mu \mathrm{g} / \mathrm{L}($ mean $\pm \mathrm{SD})$, and 15 samples of these were above cut-off $(>60 \mu \mathrm{g} / \mathrm{L})$. The latter indicates skeletal muscle injury. However, the myoglobin over H-FABP ratio in these samples was $7.7 \pm 2.9$ (mean $\pm \mathrm{SD}$ ), which is markedly lower than that found in skeletal muscle tissue (ratio 20-70) ${ }^{(25)}$, thus indicating the contribution of H-FABP released from tissues other than skeletal muscle, i.e., the brain. In two of these samples the myoglobin over H-FABP ratio was 47 and 36, reflecting a dominant contribution from skeletal muscle injury in these cases.

To exclude biological variation, pre- and post ECT H-FABP values were assessed in patients with elevated H-FABP serum levels $(\mathrm{n}=8)$ and ranged from $5.1 \pm 1.9 \mu \mathrm{g} / \mathrm{L}$ pre ECT, to $8.0 \pm 3.5 \mu \mathrm{g} / \mathrm{L}$ and $6.9 \pm 3.9 \mu \mathrm{g} / \mathrm{L}$ one and three hours post ECT, respectively.

\subsection{Discussion}

This study documents, for the first time, the tissue contents of B-FABP and H-FABP in various parts of the adult human brain and shows that in some selected patients having had minor brain injury either one or both proteins are present in blood plasma in elevated concentrations. These findings indicate the possible use of B-FABP and H-FABP as biochemical markers of brain injury. 

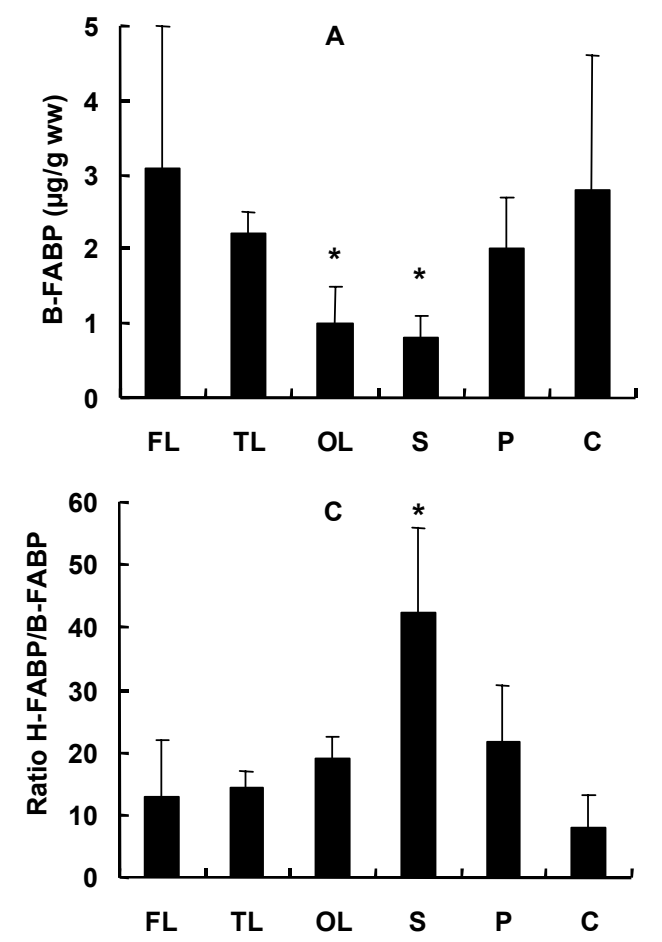

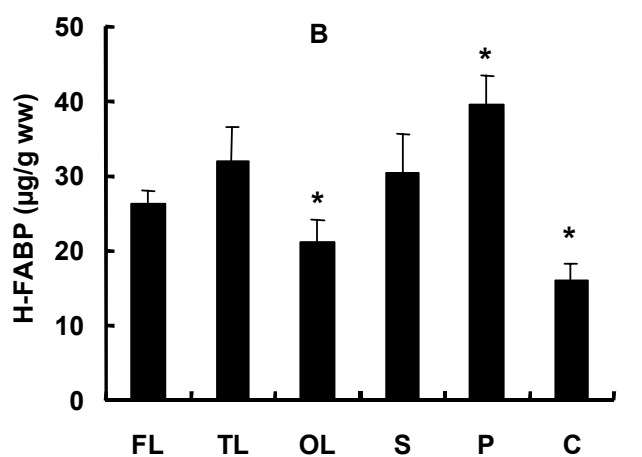

Figure 12.2 Brain tissue content (expressed as $\mu \mathrm{g} / \mathrm{g} \mathrm{ww}$ ) of A) B-FABP and B) H-FABP and C) their ratio from occipital lobe to striatum (FL, frontal lobe; TL, temporal lobe; OL, occipital lobe; S, striatum; P, pons; C, cerebellum).

${ }^{*} p<0.05$

Table 12.1 Concentrations of different biochemical marker proteins in serum samples of patients $(n=130)$ with MTBI.

\begin{tabular}{|c|c|c|c|c|}
\hline Marker protein & $\begin{array}{c}\text { Clinical cutoff } \\
\text { value (CCV) } \\
(\boldsymbol{\mu g} / \mathbf{L})\end{array}$ & $\begin{array}{c}\text { Serum samples } \\
\text { above CCV } \\
(\mathbf{n})\end{array}$ & $\begin{array}{c}\text { Serum samples } \\
\text { above CCV } \\
(\%)\end{array}$ & $\begin{array}{c}\text { Range } \\
\text { above CCV } \\
(\boldsymbol{\mu g} / \mathrm{L})\end{array}$ \\
\hline B-FABP & 5 & 88 & 68 & $5.2-128$ \\
\hline H-FABP & 6 & 91 & 70 & $6.5-182$ \\
\hline S100B & 0.3 & 59 & 45 & $0.31-10.5$ \\
\hline NSE & 10 & 66 & 51 & $10.1-100$ \\
\hline
\end{tabular}

\subsubsection{Distribution of B-FABP and H-FABP in human brain}

Although several studies already described the occurrence of B-FABP and H-FABP in specific cells in the brain ${ }^{(29,30)}$, the total tissue contents of these proteins was unknown as was the possible clinical utility due to lack of quantitative data. Therefore, we developed a B-FABP ELISA and measured the brain contents of both B-FABP and H-FABP, and investigated whether brain injury in MTBI and in ECT can be detected from the release of these proteins into blood plasma.

B-FABP tissue content was highest in the frontal lobe, while H-FABP tissue content was highest in pons. Because it has been shown that the expression of both FABPs alters during development in rodents ${ }^{(19,20)}$, it is likely that in humans the tissue contents, and also their ratio, may alter from postnatal to adult development. This aspect needs further investigation. 
Table 12.2 Concentrations of different biochemical marker proteins in 234 serum samples of 14 patients with ECT

\begin{tabular}{|c|c|c|c|c|}
\hline Marker protein & $\begin{array}{c}\text { Clinical cutoff } \\
\text { value (CCV) } \\
(\boldsymbol{\mu g} / \mathbf{L})\end{array}$ & $\begin{array}{c}\text { Serum samples } \\
\text { above CCV } \\
(\mathbf{n})\end{array}$ & $\begin{array}{c}\text { Serum samples } \\
\text { above CCV } \\
(\%)\end{array}$ & $\begin{array}{c}\text { Range } \\
\text { above CCV } \\
(\boldsymbol{\mu g} / \mathbf{L})\end{array}$ \\
\hline B-FABP & 5 & 15 & 6.4 & $7.2-51$ \\
\hline H-FABP & 6 & 39 & 17 & $6.2-20$ \\
\hline S100B & 0.3 & 1 & 0.4 & 0.35 \\
\hline
\end{tabular}

An important finding was that the ratio of H-FABP over B-FABP differs among the various parts of the human brain studied, indicating that this ratio may be used in plasma or serum to locate the site of brain injury. In the MTBI study, the H-FABP over B-FABP ratio was assessed in serum and found to be 0.58 , indicating a relatively higher release of B-FABP compared to H-FABP. However, no data (e.g. PET scan or MRI) were available to correlate the localization of brain injury with the serum data. In addition, as stated above, potential drawbacks for using the ratio of H-FABP over B-FABP are the developmental and age related changes in tissue expression of both proteins. Future studies have to address these issues in order to establish the utility of expressing a serum ratio of $\mathrm{H}-\mathrm{FABP}$ over $\mathrm{B}-\mathrm{FABP}$.

\subsubsection{B-FABP and H-FABP as biochemical markers of brain injury}

Although Guillaume et al. ${ }^{(31)}$ recently proposed the possible use of H-FABP as plasma marker for detection of Creutzfeld-Jacob disease, no quantitative data of B-FABP and HFABP as markers for brain injury have been presented before. To properly investigate the clinical utility of B-FABP and H-FABP as potential markers for brain injury, we attempted to establish a serum reference range using plasma samples from 80 healthy individuals for age and gender variation and from another 12 healthy individuals for circadian rhythm variation. Unfortunately, all samples showed a B-FABP concentration below the detection limit of the assay $(<5 \mu \mathrm{g} / \mathrm{L})$, so that possible effects on variation of plasma B-FABP could not be documented. The H-FABP plasma value of healthy individuals has been studied before and was found to increase during aging, was significantly higher in men compared to women, and was susceptible to a circadian rhythm with highest values found during the night concomitant with a decrease in the glomular filtration rate. ${ }^{(21)}$

Because traumatic brain injury is a major cause of morbidity and mortality, we investigated 130 MTBI patients. Although current knowledge about the pathophysiology of MTBI is limited, traumatically induced axonal damage is thought to be the pathophysiological mechanism in $\mathrm{MTBI}^{(32)}$, as demonstrated by elevated levels of $\mathrm{S} 100 \mathrm{~B}$ and NSE. ${ }^{(33,34)}$ In our MTBI group, both B-FABP and H-FABP were elevated in significantly $(p<0.05)$ more cases $(68$ and $70 \%$, respectively) than were protein $\mathrm{S} 100 \mathrm{~B}$ $(45 \%)$ and NSE (51\%), indicating a clear difference in sensitivity (Table 12.2). However, no significant correlations were found among serum levels of each of the biomarkers as only $45 \%$ of the samples showed both elevated levels of B-FABP and H-FABP, suggesting either different release kinetics or injury in different areas of the brain. The latter seems more likely because the release kinetics are not expected to differ among types of FABP. ${ }^{(14,35)}$ Firstly, the FABPs, and also myoglobin and S100B, are cytosolic proteins and, therefore, released simultaneously from injured cells. Secondly, the release 
of cerebrovascular proteins into blood plasma is dependent on the disruption of the blood-brain barrier (reviewed recently by Marchi et al. ${ }^{(36)}$ ), but because these proteins are of similar size (FABP, $15 \mathrm{kD}$; myoglobin, $17 \mathrm{kD}$; S100B, $22 \mathrm{kD}$ ), they will not be discriminated while passing the blood-brain barrier. Thirdly, their similar size also implies the elimination of these proteins from plasma to occur by renal clearance and at equal rates. As a result, both $\mathrm{FABPs}{ }^{(35)}$, and $\mathrm{S} 100 \mathrm{~B}^{(37)}$ show a plasma half-life time of 20$25 \mathrm{~min}$, indicating that the so-called diagnostic time window is limited indeed but similar for the FABPs and S100B. The use of B-FABP and H-FABP as biomarkers for early identification and treatment stratification of MTBI patients presenting with headache, dizziness, and nausea in the Emergency Room may well improve patient care and outcome. It is known that in patients with acute ischemic injury, rapid start of treatment will decrease the amount of neuronal cell death. ${ }^{(36)}$

Electroconvulsive therapy (ECT) is an effective method for treatment of mental illness. Although this method is still subject to debate, several studies have reported that no structural brain damage occurs during such therapy. ${ }^{(38)}$ Thus, ECT, especially bilateral

ECT, appears to be an effective short-term treatment for severe depression. ${ }^{(39)}$ Nevertheless, in our study we found 2 patients (out of 14) with elevated B-FABP levels during therapy, indicating minor brain injury. Clinical data indicated no other reasons for brain injury in these patients. In addition, H-FABP was randomly elevated in 39 samples (8 of 14 patients). Because one of the side-effects of ECT is muscle stiffness and $\mathrm{H}$ FABP can also be released from cardiac or skeletal muscle ${ }^{(14)}$, we measured myoglobin in these samples as the plasma myoglobin/H-FABP ratio is indicative for the tissue that is injured (skeletal muscle, ratio 20-70; cardiac muscle, ratio $3-5) .{ }^{(25,26)}$ The mean ratio $( \pm \mathrm{SD}$ ) was $7.7 \pm 2.9$, which indicates, assuming no cardiac muscle injury, that release of H-FABP from brain was more important than release from skeletal muscle. Taken together, these findings show that ECT not only causes some skeletal muscle injury, but in selected cases also minor brain injury as evidenced from the release of H-FABP. Because S100B was elevated in only 1 out of 234 serum samples, the ECT study also shows that H-FABP is a more sensitive marker for minor brain injury than the currently used S100B.

\subsubsection{Concluding remarks}

In summary, we have shown in two distinct patient groups that B-FABP and H-FABP may be useful markers for minor brain injury because they display a higher sensitivity than S100B. ECT may induce minor brain injury, but correlations between injury and function will depend on the localization of the injury. The same holds true for MTBI. Future studies have to confirm these observations. Now that the FABP tissue contents are known, and assuming that the release of FABPs into the circulation is the result of release from damaged brain cells rather than changes in permeability of the blood-brain barrier $^{(36)}$, the size of brain injury may be estimated from the cumulative release of FABP into plasma, provided that (i) frequent blood samples are taken, (ii) an exact location of the infarct is confirmed by a MRI scan, and (iii) the changes in tissue expression of the FABPs during aging are known.

Although B-FABP and H-FABP appear to be rapidly released into the circulation, early detection of acute brain injury like stroke would allow the early installment of therapy only when rapid detection systems are available. For H-FABP, rapid assays are already available, such as a micro-particle enhanced immuno-assay ${ }^{(40)}$, an amperometric enzyme immuno-sensor $^{(41)}$ and lateral-flow assays. ${ }^{(42)}$ In addition, new developments in on-line 
measurement of $\mathrm{FABP}^{(43)}$ would enable rapid detection of brain injury and/or changes in permeability of the blood-brain barrier, for instance during cardiac by-pass surgery due to reduced blood flow. ${ }^{(7)}$ However, renal impairment, complement activation and lowered body temperature can influence the plasma protein pattern and will have to be taken into account.

Now that thrombolytic therapy after an acute ischemic stroke is a an important new step to reduce the severity of brain injury ${ }^{(4)}$, rapid detection of brain injury and monitoring the effects of thrombolytic treatment is likely to receive increased attention in the future.

\subsection{References}

1. Lamers KJB, Vos P, Verbeek MM, Rosmalen F, van Geel WJA, et al. Protein S-100B, neuron-specific enolase (NSE), myelin basic protein (MBP) and glial fibrillary acidic protein (GFAP) in cerebrospinal fluid (CSF) and blood of neurological patients. Brain Res Bull 2003;61:261-4.

2. Rothermundt M, Peters M, Prehn JHM, Arolt V. S100B in brain damage and neurodegeneration. Microsc Res Tech 2003;60:614-32.

3. Verbeek MM, De Jong D, Kremer HP. Brain-specific proteins in cerebrospinal fluid for the diagnosis of neurodegenerative diseases. Ann Clin Biochem 2003;40:25-40.

4. Aurrel A, Rosengren LE, Karlsson B, Ollson J, Zbornikove V, et al. Determination of S-100 and glial fibrillary acidic protein concentration in CSF after brain infarction. Stroke 1991;22:1254-8.

5. Romner B, Ingebrigtsen T, Kongstad P, Borgesen SE. Traumatic brain damage: serum S-100 protein measurements related to neuroradiological findings. J Neurotrauma 2000;17:641-7.

6. Herrmann M, Vos PE, Wunderlich MT, de Bruijn CH, Lamers KJ. Release of glial tissue specific protein after acute stroke: a comparative analysis of serum concentrations of protein S-100B and glial fibrillary acidic protein. Stroke 2000;31:2670-7.

7. Kilminster S, Treasure T, McMillam T, Holt DW. Neuropsychological change and S-100 protein release in 130 unselected patients undergoing cardiac surgery. Stroke 1999;30:186974.

8. Martens P, Raabe A, Johnsson. Serum S-100 and neuron-specific enolase for prediction of regaining consciousness after global cerebral ischemia. Stroke 1998;29:2363-6.

9. Nakagawa H, Yamada M, Kanayama T, Tsuruzono K, Miyawaki Y, et al. Myelin basic protein in the cerebrospinal fluid of patients with brain tumors. Neurosurg 1994;34:825-33.

10. Nooijen PTGA, Schoonderwaldt HC, Wevers RA, Hommes OR, et al. Neuronspecific enolase, S-100 protein, myelinbas protein and lactate in CSF in dementia. Dement Geriatr Cogn Disord 1997;8:169-73.

11. Mussack T, Biberthaler P, Kanz KG, Wiedemann E, Gippber-Steppert C, et al. Serum S$100 \mathrm{~B}$ and interleukine-8 as predictive marker for comparative neurologic outcome analysis of patients after cardiac arrest and severe traumatic brain injury. Crit Care Med 2002;30:266974.

12. Missler U, Orlowski N, Nötzold A, Dibbelt L, Steinmeier E, et al. Early elevation of S-100B protein in blood after cardiac surgery is not a predictor of ischemic cerebral injury. Clin Chim Acta 2002;321:29-33.

13. Ishii J, Wang JH, Naruse H, Taga S, Kinoshita M, et al. Serum concentrations of myoglobin vs human heart-type cytoplasmic fatty acid-binding protein in early detection of acute myocardial infarction. Clin Chem 1997;43:1372-8.

14. Glatz JFC, Van der Voort D, Hermens WT. Fatty acid-binding protein as the earliest available plasma marker of acute myocardial injury. J Clin Lig Assay 2002;25:167-77.

15. Myers-Pane SC, Hubbel T, Pu L, Schnütgen F, Börchers T, et al. Isolation and characterization of two fatty acid-binding proteins from mouse brain. $J$ Neurochem 1996;66:1648-56. 
16. Glatz JFC, Van der Vusse GJ. Cellular fatty acid-binding proteins: their function and physiological signification. Prog Lipid Res 1996;3:243-82.

17. Kurtz A, Zimmer A, Schnütgen F, Brüning G, Spener F, et al. The expression pattern of a novel gene encoding brain-fatty acid binding protein correlates with neuronal and glial cell development. Development 1994;120:2637-49.

18. Feng L, Hatten ME, Heintz N. Brain lipid-binding protein (BLBP): a novel signaling system in the developing mammalian CNS. Neuron 1994;12:895-908.

19. Pu L, Igbavboa U, Wood WG, Roths JB, Kier AB, et al. Expression of fatty acid binding protein is altered in aged mouse brain. Mol Cell Biochem 1999;198:69-78.

20. Heuckeroth RO, Birkenmeier EH, Levin MS, Gordon JI. Analysis of the tissue-specific expression, developmental regulation, and linkage relationships of a rodent gene encoding heart fatty acid binding protein. J Biol Chem 1987;262:9709-17.

21. Pelsers MMAL, Chapelle JP, Knapen M, Hermens WT, Glatz JFC. Influence of age and sex and day-to-day and within-day biological variation on plasma concentrations of fatty acidbinding protein and myoglobin in healthy subjects. Clin Chem 1999;45:441-3.

22. Balendiran GK, Schnütgen F, Scapin G, Börchers T, Xhong N, et al. Crystal structure and thermodynamic analysis of human brain fatty acid-binding protein. $J$ Biol Chem 2000;275:27045-54.

23. Wodzig KWH, Pelsers MMAL, Van der Vusse GJ, Roos W, Glatz JFC. One-step enzymelinked immunosorbent assay (ELISA) for plasma fatty acid-binding protein. Ann Clin Biochem 1997;34:263-8.

24. Roos W, Eymann E, Symannek M, Duppenthaler J, Wodzig KWH, et al. Monoclonal antibodies to human heart fatty acid-binding protein. J Immunol Methods 1995;183:149-53.

25. Van Nieuwenhoven FA, Kleine AH, Wodzig WH, Hermens WT, Kragten HA, et al. Discrimination between myocardial and skeletal muscle injury by assessment of the plasma ratio of myoglobin over fatty acid-binding protein. Circulation 1995;92:2848-54.

26. Sorichter S, Mair J, Koller A, Pelsers MMAL, Puschendorf B, et al. Early assessment of exercise induced skeletal muscle injury using plasma fatty acid-binding protein. Brit J Sports Med 1998;32:121-4.

27. Jensen R, Marshak DR, Anderson C, Lukas TJ, Watterson DM. Characterization of human brain S100 protein fraction: amino acid sequence of S100ß. J Neurochem 1985;45:700-5.

28. Baudier J, Glasser N, Haglid K, Gerard D. Purification, characterization and ion binding properties of human brain S100b protein. Biochim Biophys Acta 1984;790:164-73.

29. Owada Y, Utsunomiya A, Kondo H. Spatio-temporally differential expression of the mRNA for brain- and skin-type but not heart-type fatty acid-binding proteins following kainic acid systemic administration in the hippocampal glia of adult rats. Mol Brain Res 1996;42:156-60.

30. Sellner PA, Chu W, Glatz JFC, Berman NEJ. Developmental role of fatty acid-binding proteins in the mouse brain. Dev Brain Res 1995;89:33-46.

31. Guillaume E, Zimmerman C, Burkhard P, Hochstrasser D, Sanches J. A Potential cerebrospinal fluid and plasmatic marker for the diagnosis of Creutzfeldt-Jakob disease. Proteomics 2003;3:1495-9.

32. Povlishock JT, Jenkins LW. Are the patho-biological changes evoked by traumatic brain injury immediate and irreversible? Brain Pathol 1995;5:415-26.

33. Skogseid I, Nordby H, Urdal P, Paus E, Lilleaas F. Increased serum Creatine Kinase BB and Neuron Specific Enolase following head injury. Acta Neurochir (Wien) 1992;115:106-11.

34. Ingebritsen T, Romner B, Trumpy J. Managment of minor head injury: the value of early computed tomography and serum protein S-100 measurements. J Clin Neuroscience 1997;4:29-33.

35. De Groot MJM, Wodzig KWH, Simoons ML, Glatz JFC, Hermens WT. Measurement of myocardial infarct size from plasma fatty acid-binding protein or myoglobin, using individually estimated clearance rates. Cardiovasc Res 1999;44:315-24.

36. Marchi N, Cavaglia M, Fazio V, Bhudia S, Hallene K, et al. Peripheral markers of bloodbrain barrier damage. Clin Chim Acta 2004;342:1-12. 
37. Jönsson H, Johnsson P, Hoglund P, Alling C, Blonquist S. Elimination of S100B and renal function after cardiac surgery. J Cardiothorac Vasc Anesth 2000;6:698-701.

38. Devanand DP, Dwork AJ, Hutchinson ER, Bolwig TG, Sackheim HA. Does ECT alter brain structure? Am J Psychiatry 1994;151:957-70.

39. UK ECT Review Group. Efficacy and safety of electroconvulsive therapy in depressive disorders: a systematic review and meta-analysis. Lancet 2003;361:799-808.

40. Robers M, van der Hulst FF, Fischer M, Roos W, Eisenwiener H, et al. Development of a rapid microparticle-enhanced turbidimetric immunoassay for fatty acid-binding protein in plasma, an early marker of acute myocardial infarction. Clin Chem 1998;44:1564-7.

41. Key G, Schreiber A, Feldbrügge R, McNeil CJ, Jørgenson P, et al. Multicenter evaluation of an amperometric immunosensor for plasma fatty acid-binding protein: an early marker for acute myocardial infarction. Clin Biochem 1999;32:229-31.

42. Watanabe T, Ohkubo Y, Matsuoka H, Kimura H, Sakai Y, et al. Development of a simple whole blood panel test for detection of human heart-type fatty acid-binding protein. Clin Biochem 2001;34:257-63.

43. Van der Voort D, Pelsers MMAL, Korf J, Hermens WT, Glatz JFC. Development of a displacement immunoassay for human heart-type fatty acid-binding protein in plasma: the basic conditions. Biosens Bioelectron 2003,19:465-71.

44. Broderick JP, Hacke W. Treatment of ischemic stroke. Part I: Recanalization strategies. Circulation 2002;106:1563-69. 
Chapter 12 


\section{General discussion}

\subsection{Tissue injury and disease}

Tissue injury may arise, for instance, from trauma, poisoning or rejection but predominantly is the result of ischemia/reperfusion (I/R). The reduction of blood-flow due to either surgical procedures, organ procurement for transplantation or an occluded artery leads to a state of hypoxia as the cells then are deprived from sufficient oxygen. Occlusion of an artery may occur when atherosclerotic plaques are formed, although the heart can compensate for the gradual decrease in blood flow up to $70 \%$ occlusion. However, when the fibrous cap of the plaques become thin and unstable due to vascularization and the formation of foam cells within the plaque, rupture of the plaque is likely to occur. ${ }^{(1)}$ The exposure to sub-endothelial collagen and von Willebrand factor then induces adherence of platelets and triggers the coagulation cascade and formation of a thrombus (Fig. 13.1). ${ }^{(2)}$ This thrombus can lead to massive ischemia in the coronary arteries and, when fragmentized and released into the circulation, also to lung and brain embolic vascular occlusions resulting for instance in stroke.

During ischemia, cells and tissues undergo rapid changes in metabolic flux, signaling pathways and surface molecule expression. ${ }^{(3,4)}$ After re-connection of the vasculature or re-establishment of the circulation by thrombolytic therapy ${ }^{(2,5)}$, oxygen is re-applied to the cells and repair mechanisms are set into place. However, during ischemia, free radicals accumulate intracellular and after reperfusion, are also flushed into the system, resulting in activation of the inflammatory cascade with activation, adhesion and migration of neutrophils. The latter cause so-called secondary tissue injury by oxidative burst. ${ }^{(4)}$ Therefore, the administration of anti-inflammatory drugs like c1esterase inhibitors $^{(6)}$ after thrombolytic therapy is currently being investigated to reduce tissue injury after myocardial infarction.

Besides prevention of the occurrence and rupture of atherosclerotic plaques, also an earlier diagnosis will help to limit the total amount of tissue injury. An earlier diagnosis will allow the earlier installment of appropriate therapy aimed at reduction of tissue injury.

\subsection{Clinical relevance of biochemical markers for detection of tissue injury}

In many diseases like myocardial infarction, stroke, embolic vascular occlusions, unstable angina pectoris and cardiac surgery, tissue injury is an important parameter. Due to cell death, cytoplasmic proteins are released by the cell and diffuse into the circulation (see Chapter 2). ${ }^{(7)}$ The rapid detection of these cell death indicators (biochemical markers), is of major importance for stratifying patient management and improving treatment. Not only can positively diagnosed patients be treated more effectively, a major reduction in hospital costs is achieved when negatively diagnosed patients can be sent home safely instead of being hospitalized for observation. 
The successful implication of biochemical markers in the early phase of designing the appropriate treatment strategy is dependent on several factors. First, marker proteins differ in the time needed to be released from damaged cells into the circulation, as well as in the rate of elimination from plasma; these two parameters together determine the plasma reference value. Therefore, at present much effort is made to identify those, tissue specific proteins, which are earlier elevated above their plasma reference value than currently used biomarker proteins. Secondly, the application of new technologies for more rapid analyses of these biochemical markers is needed to permit an earlier evaluation. In particular, the improvement of bedside testing, i.e., the so-called point-ofcare testing, receives much attention and will dramatically stimulate the clinical application of biochemical marker proteins.

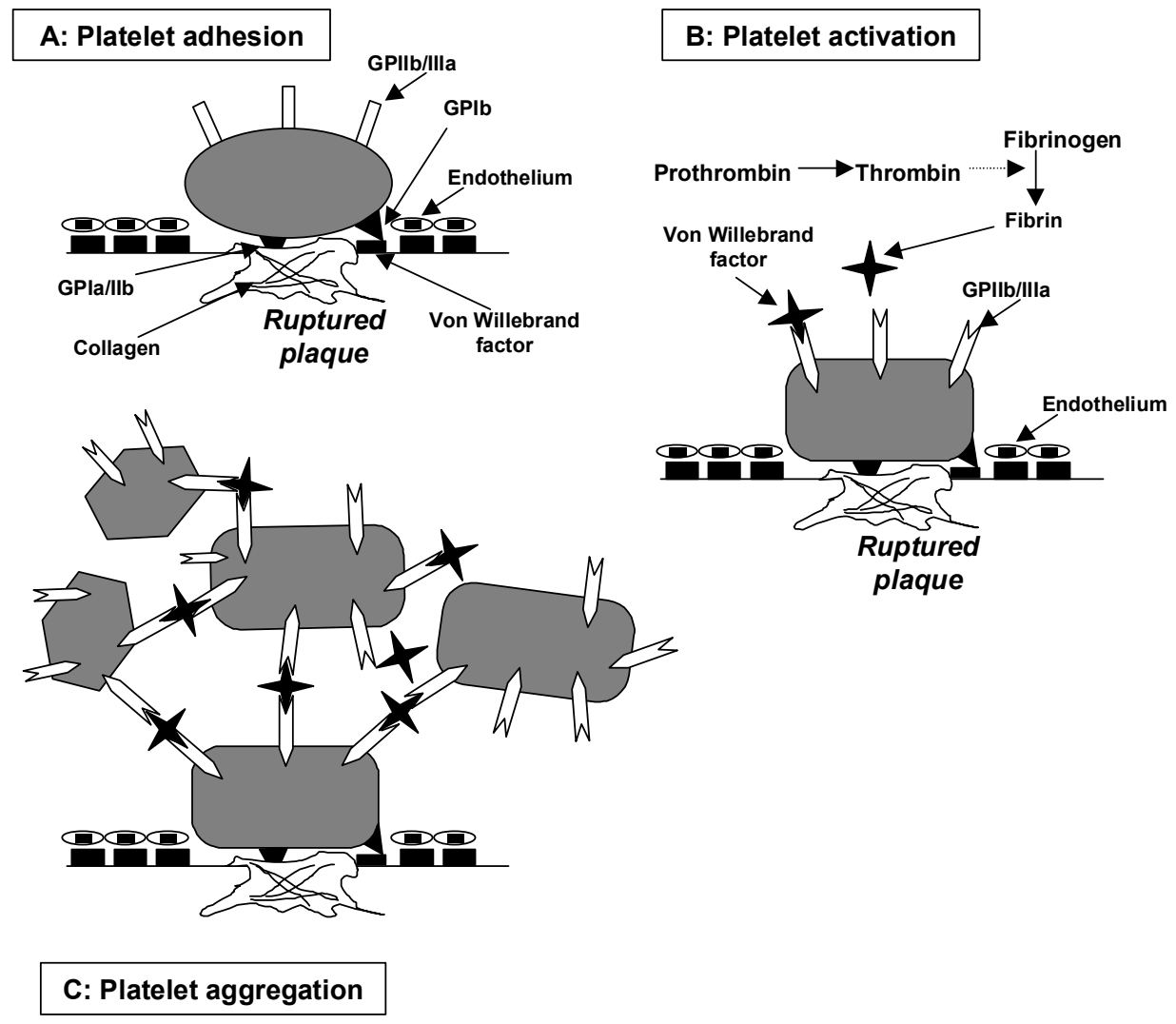

Figure 13.1 A) Rupture of a fibrous plaque exposes the subendothelial proteins collagen and von Willebrand factor, leading to adhesion via the platelet's surface receptors. B) This adhesion causes platelet activation, which triggers a conformational change in the platelet's glycoprotein (GP) Ilb/llla receptor and generates the enzyme thrombin, from circulating prothrombin, which converts fibrinogen to fibrin. Fibrin and von Willebrand factor vWF bind to the (GP) Ilb/llla receptor. C) Fibrin and vWF are multivalent, so they bind to (trap) multiple activated platelets leading to their aggregation. Together they make up the framework of a white thrombus.

Adapted from reference 2 with permission.

\subsection{FABP in tissue injury detection}

Following cell death, intracellular proteins are released and diffuse via the interstitium and the endothelial clefts into the circulation. Because the size of these clefts ranges from wide in liver via small in heart and narrow in skeletal muscle to practically impermeable 
in brain (blood-brain barrier), small proteins appear more rapidly into the circulation than large proteins. ${ }^{(7)}$ The time of significant elevation of these biochemical markers above the reference level in plasma is dependent on the rate at which the plasma value of these proteins rises after injury. ${ }^{(8,9)}$ This rise is dependent on the tissue content, molecular size and half-life in plasma of the respective protein. The ideal marker for tissue injury detection, therefore, would be a tissue specific protein with small molecular size, high tissue content and low plasma value in healthy individuals.

\subsubsection{Reference value}

When investigating the clinical utility of a new biochemical marker protein, a proper reference interval and a reference value, also termed clinical cut-off value or upper reference limit, have to be established first. Biological variation in plasma protein levels due to age, sex, circadian rhythm and day-to-day variation has to be investigated in healthy individuals and non-symptomatic patients. Many investigators have used the $95 \%$ confidence interval (mean+2SD) in plasma levels of normal healthy individuals as reference value, although nowadays the $99 \%$ confidence interval (mean $+3 \mathrm{SD}$ ) is more and more becoming the standard as new and more sensitive detection methods are being developed. Another method to calculate the reference value is via receiver operating characteristic (ROC) curves. Here sensitivity and specificity are compared in groups of symptomatic- versus non-symptomatic patients to express the ability of a reference value to discriminate patients having the disease from those with similar complaints but not having the disease. ${ }^{(10,11)}$

\subsubsection{Heart}

The field of cardiac injury is a good example of the development of biochemical markers for rapid and specific detection of tissue injury. Already since 30 years ${ }^{(12)}$, next to patient history and ECG, the typical rise and fall of plasma values of cardiac proteins is part of three criteria to diagnose myocardial injury in patients with acute coronary syndromes. Recent revision of the protocol for detection of cardiac injury in such cases has even enhanced the value of biochemical markers. ${ }^{(13)}$

Because the time between onset of symptoms and entrance of the patient in the emergency department, i.e., the hospital delay, is not always known, distinction should be made between "early" and "late" markers. When the time of onset of symptoms is known, the choice for measurement of an early or a late marker can be made. However, in case that the time of onset is unknown, both types of markers should be measured so as to extend the so-called diagnostic window. ${ }^{(14)}$ Relatively large cardiac marker proteins like CK-MB and LDH enter the circulation rather slow and can not be applied as early markers. Currently, the troponins, due to their cardiac specificity, are generally accepted as suitable late markers. ${ }^{(15)}$ The troponins (types T, I and C) are structural components of the cardiac muscle and first need to be released and fragmented from the tropomyosin complex before they enter the circulation. ${ }^{(16)}$ Therefore, the troponins are late markers. In addition, they are elevated in plasma for several days, which makes them even more suitable for late diagnosis.

H-FABP and myoglobin each are early markers and are rapidly cleared from the circulation by the kidneys. Therefore, they are very useful as early marker in the time interval up to approximately 24-36 h after onset of symptoms. As their plasma levels peak between 6 and $12 \mathrm{~h}$ after infarction and return to normal within 24 to $36 \mathrm{~h}$ 
(depending on the use of thrombolytics), they can also be used to indicate a reinfarction. ${ }^{(17)}$ Although myoglobin is currently recommended as preferred early cardiac marker $^{(13)}$, H-FABP would be a better choice. As stated in Chapter 2, H-FABP has a higher specificity and sensitivity than myoglobin for the detection of myocardial injury, which is expressed in a higher area under the curves of the ROC analysis. ${ }^{(18-22)}$ Due to the relatively low plasma concentration of H-FABP in healthy individuals ${ }^{(23)}$ and its high tissue content, H-FABP shows a sensitivity that even allows the detection of minor myocardial injury in patients with chronic heart failure or unstable angina pectoris ${ }^{(24-26)}$ (see Chapter 6). The prognostic value of plasma H-FABP for recurrent events in patients with chronic heart failure, as found in this study ${ }^{(26)}$, is significantly better than that for cTnT and, therefore, should be subject of further clinical studies.

When investigating the relative increase of plasma H-FABP values (Chapter 2, Fig. 2.4) between admission and 1-2 $\mathrm{h}$ after admission, irrespective of the absolute plasma concentration (i.e., whether below or above the reference value), H-FABP shows a superior performance for exclusion of acute myocardial injury. ${ }^{(8,9)}$ However, for proper use of this relative rise in H-FABP, patients have to be admitted to the hospital within $6 \mathrm{~h}$ after onset of symptoms as peak values of H-FABP are reached between 6 and $12 \mathrm{~h}$ after onset. $^{(14)}$ Taken together, a combination of H-FABP as early marker and troponin T or I as late marker would be the ideal set of markers for a proper diagnostic window for the detection of acute coronary syndromes.

\subsubsection{Skeletal muscle}

Although predominantly expressed in cardiomyocytes, H-FABP is also expressed in skeletal muscle and, therefore, can be used as marker for skeletal muscle injury (Chapter 7). This application for muscle injury detection can be exploited in training programs of athletes as was investigated in downhill running ${ }^{(27)}$ and rowing ${ }^{(28)}$, but also in horses to investigate muscle stiffness or skeletal muscle injury after racing (Chapter 4).

The potential drawback of skeletal muscle H-FABP release for the application of H-FABP as cardiac marker can be overcome by also measuring myoglobin and expressing the ratio. The plasma ratio of myoglobin over H-FABP discriminates myocardial injury (ratio between 2 and 5) from skeletal muscle injury (ratio between 20 and 70). ${ }^{(28,29)}$

This ratio can also be used in coronary by-pass surgery to discriminate between either a post-operative myocardial infarction or skeletal injury due to surgery ${ }^{(30-33)}$, thereby applying an additional clinical parameter for the surgeon to decrease mortality in this procedure.

\subsubsection{Kidney}

Another new finding is the monitoring of H-FABP, released from kidney distal tubular cells, for toxicity testing (Chapter 8 ) or for viability testing of non-heart-beating donor kidneys (Chapter 9).

Applying different compounds, it was shown that H-FABP is a good marker for detection of distal tubular injury. Similarly, L-FABP needs to be evaluated as marker for proximal tubular injury as both GST isoforms showed this application. Gentamicin and mercuric chloride induce differently located major nephrotic injury, while cyclosporin shows only minor injury. 
As the pool for donor kidneys is still not coping with the needs for transplantation, new ways have to be investigated to increase the number of available transplantable kidneys. Although kidneys from non-heart-beating donors are subject to a period of ischemia, it is shown in perfusion effluent that viability testing via biochemical marker proteins and kidney perfusion characteristics can predict the short-term function of these kidneys. ${ }^{(34-36)}$ For this purpose, H-FABP performed comparable with GST and Ala-AP, with the tendency of H-FABP being the most sensitive marker. Although these protein markers did not predict the efficacy of renal function in the long-term, the use for short-term screening of kidney function does lead to a survival rate of non-heart-beating-donor kidneys which is sufficient to serve as an important source to match the increasing waiting lists. Because the marker proteins performed comparable, test-costs and total measurement time will be of major importance for implication of one of these proteins.

TotalGST is a relatively inexpensive enzymatic assay, but the possible on-line measurement of $\mathrm{H}-\mathrm{FABP}^{(37)}$ in the perfusion effluent would be a perfect match of sensortechnology and clinical application.

\subsubsection{Liver}

Liver-type FABP is, next to H-FABP, the other FABP-type that shows multi-tissue expression. ${ }^{(38)} \mathrm{We}$ showed for the first time that L-FABP is a more sensitive marker of tissue injury due to rejection post-transplantation than the currently used markers GST and ALT (see Chapter 10). Although the liver is capable of regenerating large amounts of lost liver-tissue, a cascade of events after rejection leading to tissue injury and final dysfunction of the liver is life threatening to the patient and emphasizes the use of biochemical marker proteins for the rapid detection of rejection injury, followed by a better immunosuppressive treatment. The incorporation of GST already showed marked reduction in mortality and morbidity. ${ }^{(39)}$

\subsubsection{Intestine}

Although several studies already have evaluated I-FABP as marker for intestinal injury (Chapter 11), differences in assay calibrators and clinical outcome have prevented a routine clinical application of I-FABP. We have investigated tissue content of I-FABP and L-FABP in segments of the small intestinal tract and found, surprisingly, that the LFABP tissue content is markedly higher than that of tissue specific I-FABP. In line with this, L-FABP appeared a more sensitive marker than I-FABP for intestinal injury, as was also confirmed by Guthmann et al. ${ }^{(40,41)}$ However, should more sensitive assays for the detection of I-FABP be developed these would enable the measurement of relative small increases of plasma I-FABP values and more tissue-specific injury.

\subsubsection{Brain}

The most recent finding is that H-FABP and B-FABP are more sensitive markers for the detection of brain-injury than the currently used markers S100B and NSE. The fact that both FABPs were elevated in plasma of patients with mild trauma or electroshock therapy within $6 \mathrm{~h}$ was quite surprising because the blood-brain barrier is practically impermeable indicating that mild trauma and electroshock therapy also damage this barrier (see Chapter 12). ${ }^{(42)}$ Very recently, these data could be confirmed by preliminary results in 42 patients suffering from acute ischemic stroke (Wunderlich, Pelsers, 
unpublished observations) where H-FABP and B-FABP concentrations showed peak values already 2 to $3 \mathrm{~h}$ after onset of stroke, and both proteins remained elevated (Fig. 13.2).

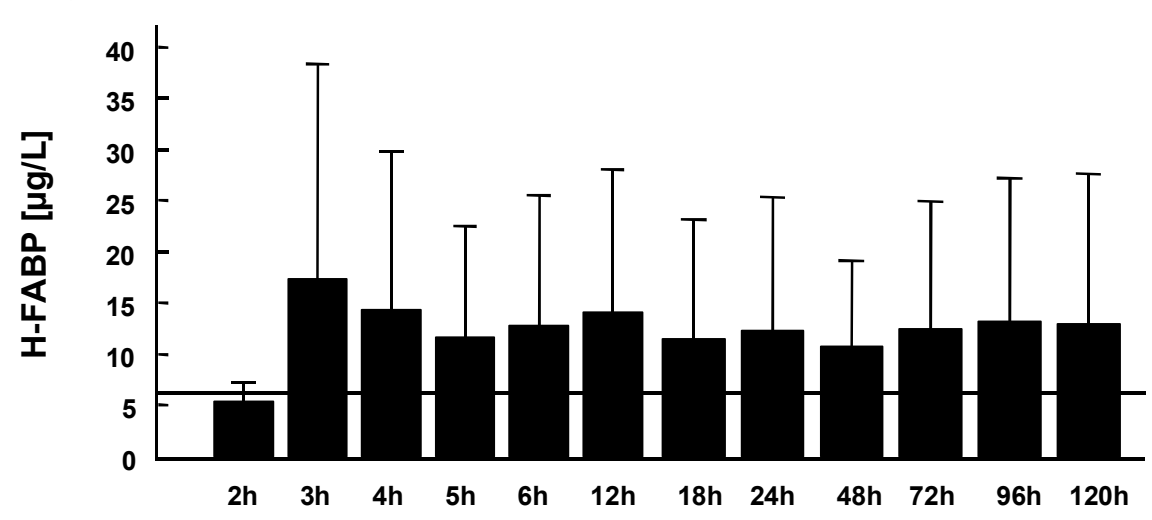

\section{Figure 13.2}

Release of $\mathrm{H}-\mathrm{FABP}$ (top panel) and BFABP (lower panel) in plasma of 42 consecutive patients admitted within $6 \mathrm{~h}$ (median $3 \mathrm{~h}$ ) after stroke onset. Line indicates the respective reference

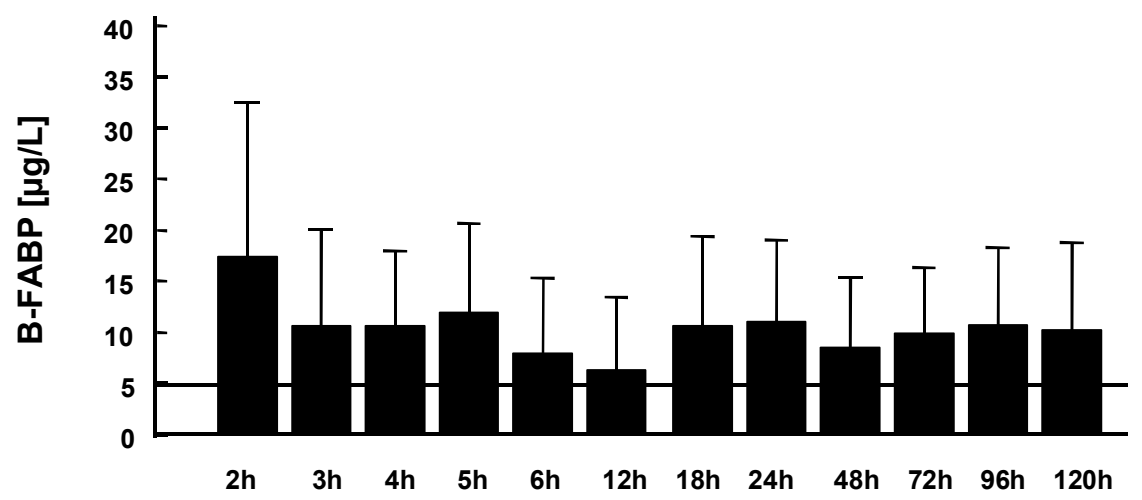

Time after stroke (h)

Although a larger infarction volume was associated with a higher H-FABP release, no correlation between FABP values and lesion volume or lesion location could be found. Unlike B-FABP, H-FABP concentrations were significantly associated with the National Institutes of Health stroke scale score and the functional outcome. These studies show for the first time quantitative data of plasma/serum H-FABP and B-FABP being elevated early after mild trauma, electroshock or acute stroke and therefore can be used as biochemical markers of brain damage. Both are not specific for cerebral infarction but indicate damage to neuronal and glial tissue. In conclusion, H-FABP may be of interest as an additional monitoring parameter and outcome predictor in acute ischemic stroke, but release kinetics need to be evaluated in cerebrospinal fluid and plasma to establish a proper diagnostic window.

\subsection{Point-of-care testing}

As outlined above, improvement of patient treatment by measuring early biochemical markers, requires their rapid analysis in plasma. The so-called point-of-care testing consists of (i) bedside testing by handhold devices instead of a time delay by sending samples to the clinical laboratory or (ii) decreased measurement time by more rapid testsystems.

Bedside testing is mainly based on semi-quantitative lateral flow assays, imbedded in either small size apparatus or handhold strips. Especially in the field of acute coronary 
syndromes, point-of-care testing provides important information to rapidly identify patients with myocardial injury. For instance, the Roche Cardiac Reader (Roche Diagnostics, Basel, Switzerland) is a tabletop system that measures both troponin $\mathrm{T}$ and myoglobin, in whole blood, in $12 \mathrm{~min}$. If samples are above cut-off value, clinicians can already start treatment while for a quantitative measurement, samples will be send to the central laboratory. Handhold strips as described by Chan et al. ${ }^{(43)}$ and Watanabe et al. ${ }^{(4)}$ also provide a yes or no answer. In general, a few drops of blood are added and plasma migrates into the sample pad due to capillary action. Monoclonal antibodies, often labeled with colloidal gold, migrate with the bound antigen to a detection zone where capture antibodies are coated. Aggregation of the antigen-antibody complex then leads to a visible line. The Cardiodetect ${ }^{\mathbb{B}}$ is a commercially available teststrip for detection of $\mathrm{H}$ FABP (Figs 13.3 and 13.4).

Decreased measuring time is another important parameter. Therefore, laborious sandwich-type immunoassays (ELISAs) are more and more replaced by automated micro-particle enhanced immunoassays like described by Robers et al. ${ }^{(45)}$ Enabling the patient sample to be delivered as soon as possible to a central lab or a near patient lab is also an important aspect to decrease logistics of patient sample measurement.

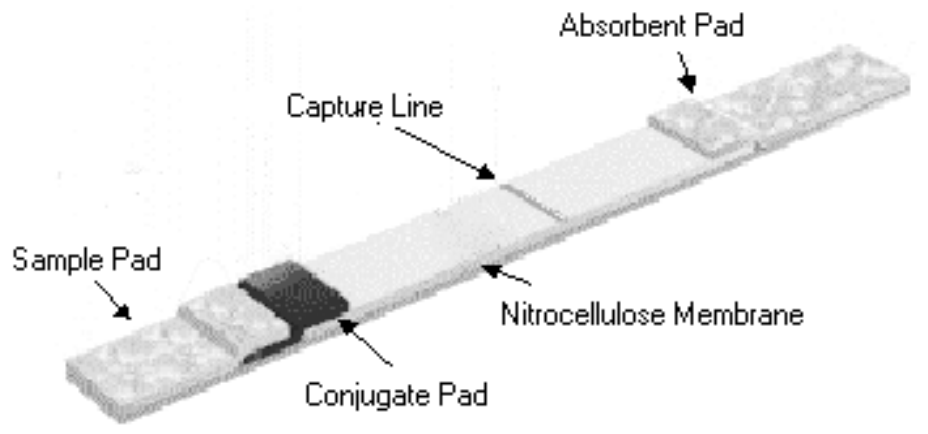

Figure 13.3 Presentation of Car dio-detect $^{\circledR}$ test, adapted from www.rennesens.de.

\subsection{Future perspectives}

FABP appears to be a pivotal parameter in rapid tissue injury detection. Although not all FABP types (H- and L-FABP) are tissue specific, they still have been reported as the most sensitive markers for early detection of myocardial, skeletal, kidney and brain injury (H-FABP), liver and intestinal injury (L-FABP), intestinal (I-FABP) and brain injury (BFABP). New rapid test systems applying specific monoclonal antibodies and antigens will allow FABP to be used in the clinical setting, together with other clinical parameters, to diagnose and treat patients as early as possible so that mortality and morbidity can be decreased. The ratio of plasma values of different FABP types might even be used to locate the site of tissue injury.

Future research mainly should focus on 3 aspects. First, the prognostic value of most diagnostic markers has not been evaluated properly and needs more study. Especially in patients with chronic heart failure, in which a continuous low grade cell damage is reported, H-FABP shows a significant better negative predictive value than cTnT for the appearance of recurrent events (see Chapter 6). Second, serial measurements of marker proteins will increase the sensitivity and specificity of the markers as a relative increase, independent of absolute plasma values, already can indicate tissue injury, even when plasma values are below reference value. This observation will allow the clinician to start treatment as early as possible, which is not only important for myocardial injury (see 
Chapter 2), but also for detection of rejection injury of kidney- or liver transplants, intestinal diseases and brain injury due to stroke or mild trauma. The third focus is to effectively monitor the plasma values of biochemical markers and to allow serial measurements by on-line monitoring. Changes in the release pattern of FABP in the patients plasma can be measured with biosensors ${ }^{(37,46)}$, allowing not only detection of tissue injury, but also estimation of the extent of damage, monitoring patients who are prone to develop tissue injury and for risk stratification.

Therefore, the application of FABP as tissue injury marker has great potential for many clinical purposes.

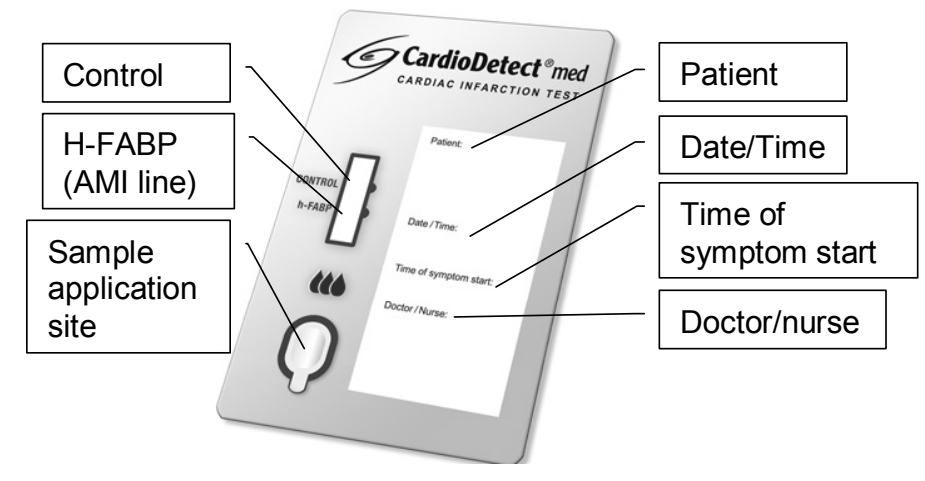

Figure 13.4 Schematic presentation of the test strip used as part of the Cardiodetect cards

\subsection{References}

1. Scott J. The pathogenesis of atherosclerosis and new opportunities for treatment and prevention. J Neural Transm Suppl 2002;63:1-17.

2. Azzazy HM, Christenson RH. Cardiac markers of acute coronary syndromes: Is there a case for point-of-care testing? Clin Biochem 2002;35:13-27.

3. Maxwell SR, Lip GY. Reperfusion injury: a review of the pathophysiology, clinical manifestations and therapeutic options. Int J Cardiol 1997;58:95-117.

4. Fondevilla C, Busuttil RW, Kupiec-Weglinski JW. Hepatic ischemia/reperfusion injury-a fresh look. Exp Mol Pathol 2003;74:86-93.

5. Wong CK, White HD. Acute myocardial infarction: Fibrinolytic therapy. Curr Treat Options Cardiovasc Med 2004;6:15-38.

6. De Zwaan C, Kleine AH, Diris JH, Glatz JF, Wellens HJ, et al. Continuous 48 h C1-inhibitor treatment, following reperfusion therapy, in patients with acute myocardial infarction. Eur Heart J 2002;23:1670-7.

7. Hermens WT. Mechanisms of protein release from injured heart muscle. Dev Cardiovasc Med 1998;205:85-98.

8. Haastrup B, Gill S, Kristensen SR, Jorgensen PJ, Glatz JFC. Biochemical markers of ischemia for the early identification of acute myocardial infarction without ST segment elevation. Cardiol 2002;94:254-61.

9. Chan CPY, Sanderson JE, Glatz JFC, Cheng WS, Hempel A, et al. A superior early myocardial infarction marker-human heart-type fatty acid-binding protein. Zeitschr Kardiol 2004; in press.

10. Metz CE. Basic principles of ROC analysis. Semin Nucl Med 1978;8:283-98.

11. Zweig MH, Campbell G. Receiver-operating characteristics (ROC) plots: a fundamental evaluation tool in clinical medicine. Clin Chem 1993;39:561-77.

12. World Health Organization, Working Group on the Establishment of Ischemic Heart Disease Registers. Report of the Fifth Working Group, Copenhagen. In: Report no. Eur 8201 (5). World Health Organization, Geneva, 1971. 
13. Alpert JS, Thygesen K, Antman E, Bassand JP. Myocardial infarction redefined-A consensus document of The Joint European Society of Cardiology/American College of Cardiology Committee for the redefinition of myocardial infarction. J Am Coll Cardiol. 2000;36:959-69.

14. Glatz JFC, van der Voort D, Hermens WT. Fatty acid-binding protein as the earliest available plasma marker of acute myocardial injury. J Clin Lig Ass 2002;25:167-77.

15. Newby LK, Goldmann BU, Ohman EM. Troponin: an important prognostic marker and risk stratification tool in non-ST-segment elevation acute coronary syndromes. $J$ Am Coll Cardiol 2003;41:31S-36S.

16. Diris JH, Hackeng CM, Kooman JP, Pinto YM, Hermens WT, et al. Impaired renal clearance explains elevated troponin T fragments in hemodialysis patients. Circulation 2004;109:23-5.

17. Glatz JFC, Kleine AH, van Nieuwenhoven FA, Hermens WT, Van Dieijen-Visser MP, et al. Fatty acid-binding protein as a plasma marker for the estimation of myocardial infarct size in humans. Br Heart $J$ 1994;71:135-40.

18. Ishii J, Wang JH, Naruse H, Taga S, Kinoshita M, et al. Serum concentrations of myoglobin vs heart-type cytoplasmic fatty acid-binding protein in early detection of acute myocardial infarction. Clin Chem 1997;43:1372-8.

19. Glatz JFC, Haastrup B, Hermens WT, de Zwaan C, Barker J, et al. Fatty acid-binding protein and the early detection of acute myocardial infarction: the EUROCARDI multicenter trial Circulation 1997;96:215.

20. Ghani F, Wu AHB, Graff L, Petry C, Armstrong G, et al. Role of heart-type fatty acidbinding protein in early detection of acute myocardial infarction. Clin Chem 2000;46:718-9.

21. Okamoto F, Sohmiya K, Okhura Y, Kawamura K, Asayama K, et al. Human heart-type cytoplasmic fatty acid-binding protein (H-FABP) for the diagnosis of acute myocardial infarction. Clinical evaluation of H-FABP in comparison with myoglobin and creatine kinase isoenzyme MB. Clin Chem Lab Med 2000;38:231-8.

22. Nakata T, Hashimoto A, Hase M, Tsuchihaski K, Shimamoto K. Human heart-type fatty acid-binding protein as an early diagnostic and prognostic marker in acute coronary syndromes. Cardiology 2003;99:96-104.

23. Pelsers MM, Chapelle JP, Knapen M, Vermeer C, Muijtjens AMM, et al. Influence of age, sex and day-to-day and within-day biological variation on plasma concentrations of fatty acid-binding protein and myoglobin in healthy subjects. Clin Chem 1999;45:441-3.

24. Katrukha A, Bereznikova A, Filatov V, et al. Improved detection of minor ischemic cardiac injury in patients with unstable angina by measurement of cTnI and fatty acid-binding protein (FABP). Clin Chem 1999;45:A139 (abstract).

25. Setsuta K, Seino Y, Ogawa T, Arao M, Miyatake Y, et al. Use of cytosolic and myofibril markers in the detection of ongoing myocardial damage in patients with chronic heart failure. Am J Med 2002;113:717-22.

26. Pelsers MMAL, Bakker J, Pinto YM, Van Dieijen-Visser MP, Hermens WT, et al. Plasma fatty acid-binding protein outperforms troponin $\mathrm{T}$ as a sensitive marker for myocardial injury in heart failure. Clin Chem Lab Med 2003;41:S11.6(abstract).

27. Sorichter S, Mair J, Koller A, Pelsers MMAL, Puschendorf B, et al. Early assessment of exercise induced skeletal muscle injury using plasma fatty acid-binding protein. Brit J Sport Med 1998;32:121-4.

28. Yuan Y, Kwong AW, Kaptein WA, Fong C, Tse M, et al. The responses of fatty acid-binding protein and creatine kinase to acute and chronic exercise in junior rowers. Res $Q$ Exerc Sport 2003; $74: 277-83$.

29. Van Nieuwenhoven FA, Kleine AH, Wodzig KWH, Hermens WT, Kragten JA, et al. Discrimination between myocardial and skeletal muscle injury by assessment of the plasma ratio of myoglobin over fatty acid-binding protein. Circulation 1995;92:2848-54.

30. Fransen EJ, Maessen JG, Hermens WT, Glatz JFC. Demonstration of ischemia-reperfusion injury separate from postoperative infarction in CABG patients. Ann Thoracic Surg 1998;65:48-53. 
31. Hayashida N, Chihara S, Akasu K, Oda T, Tayama E, et al. Plasma and urinary levels of heart fatty acid-binding protein in patients undergoing cardiac surgery. Jpn Circ J 2000;64:18-22.

32. Suzuki K, Sawa Y, Kadoba K, Takahashi T, Ichikawa H, et al. Early detection of cardiac damage with fatty acid-binding protein after cardiac operations. Ann Thorac Surg 1998;65:54-8.

33. Petzold T, Feindt P, Sunderdiek U, Boeken U, Fischer Y, et al. Heart-type fatty acid-binding protein (H-FABP) in the diagnosis of myocardial injury in coronary artery bypass grafting. Eur J Cardiothor Surg 2001;19:859-64.

34. Gok MA, Pelsers MMAL, Glatz JFC, Shenton BK, Peaston R, et al. Use of two biomarkers of renal ischemia to assess machine-perfused non-heart-beating donor kidneys. Clin Chem 2003;49:172-5.

35. Gok MA, Pelsers MMAL, Glatz JFC, Bhatti AA, Shenton BK, et al. Comparison of perfusate activities of glutathione S-transferase, alanine aminopeptidase and fatty acid-binding protein in the assessment of non heart-beating donor kidneys. Ann Clin Biochem 2003:40:252-8.

36. Gok MA, Pelsers MMAL, Glatz JFC, et al. Do tissue damage markers used to assess machine perfused NHBD kidneys predict long term renal function post-transplant? Clin Chim Acta 2003;338:33-43.

37. Van der Voort D, Pelsers MMAL, Korf J, Hermens WT, Glatz JFC. Development of a displacement immunoassay for human heart-type fatty acid-binding protein in plasma: the basic conditions. Biosens Bioelectron 2003;19:465-71.

38. Glatz JFC, van der Vusse GJ. Cellular fatty acid-binding proteins: their function and physiological signification. Prog Lipid Res 1996;3:243-82.

39. Hughes VF, Trull AK, Gimson A, Friend PJ, Jamieson N, et al. Randomized trail to evaluate the clinical benefits of serum $\alpha$-glutathione s-transferase concentration monitoring after liver transplantation. Transplant 1997;64:1446-52.

40. Guthmann F, Börchers T, Wolfrum C, Wustrack T, Bartholomaus S, et al. Plasma concentration of intestinal- and liver-FABP in neonates suffering from necrotizing enterocolitis and in healthy preterm neonates. Mol Cell Biochem 2002;239:227-34.

41. Pelsers MMAL, Namiot Z, Kisiekewski W, et al. Intestinal-type and liver-type fatty acidbinding protein in the intestine: tissue distribution and clinical utility. Clin Biochem 2003;36:529-35.

42. Pelsers M, Hanhoff T, van der Voort D, de Kruijk J, Twijnstra A, et al. Tissue specific types of fatty acid-binding proteins, B- and H-FABP, as novel markers for detection of brain injury. Clin Chem Lab Med 2003;41:P7.98.

43. Chan CPY, Sum KW, Cheung KY, et al. Development of a quantitative lateral-flow assay for rapid detection of fatty acid-binding protein. J Immunol Methods 2003;279:91-100.

44. Watanabe T, Ohkubo Y, Matsuoka H, et al. Development of a simple whole blood panel test for detection of human heart-type fatty acid-binding protein. Clin Biochem 2001;34:257-63.

45. Robers M, Van der Hulst FF, Fischer MAJG, et al. Development of a rapid microparticleenhanced turbidimetric immunoassay for plasma fatty acid-binding protein, an early marker of acute myocardial infarction. Clin Chem 1998;44:1564-67.

46. Van der Voort D, Pelsers MMAL, Korf J, Hermens WT, Glatz JFC. A displacement immunoassay for human heart-type fatty acid-binding protein in plasma. J Immunol Methods, in press. 


\section{Summary}

Reduction of patient morbidity and mortality, but also of hospital costs, are major goals in human health care research. A proper and rapid diagnosis of the status of the patient, either by the general practitioner or at the hospital, is therefore crucial. Besides anamnesis and medical history, blood parameters are becoming more and more important to properly diagnose the status of the patient. Especially in the case of management of patients with acute tissue injury, these so-called biochemical markers have become important diagnostic and prognostic parameters. Because of the general finding that 'time saves tissue', the sooner tissue injury is detected, the better patient treatment can be implemented and the more tissue can be saved. The routine application of biochemical markers eventually will lead to a reduction in morbidity and mortality, and also to a reduction in hospital costs as patients with non-disease-specific symptoms can be sent home safely.

One of the promising new markers for tissue injury detection is cytoplasmic fatty acidbinding protein $(\mathrm{FABP})$. This small $(15 \mathrm{kD})$ protein is involved in cellular long-chain fatty acid metabolism and is abundantly expressed in tissues with an active fatty acid metabolism like heart and liver. After cell damage, cellular proteins are released into the interstitium and will diffuse through endothelial clefts into the circulation. Because these clefts differ in size, small cytoplasmic proteins like FABP diffuse more rapidly through the clefts and appear earlier in the blood than large proteins.

This thesis describes the use of different types of cytoplasmic FABP for the detection of tissue injury in patients with myocardial injury, chronic heart failure, unstable angina, skeletal muscle injury, kidney toxicity and transplantation, liver transplantation, intestinal injury and brain injury, as is briefly outlined in Chapter 1.

In Chapter 2, a general review is presented on the current status of different FABP types, in comparison with established blood markers, for the detection of several organ related tissue injuries. Assay development, point-of-care testing and clinical studies are evaluated. Especially in the field of myocardial injury it is shown that heart-type FABP (H-FABP) is the superior marker for the sensitive and early detection of acute myocardial injury (AMI). Within $6 \mathrm{~h}$ after onset of symptoms, H-FABP shows a significantly higher specificity and sensitivity than the currently used early marker myoglobin $(\mathrm{Mb})$. Because cardiac troponins $\mathrm{T}$ and I are specific but rather late markers for detection of AMI, HFABP as early marker and $\mathrm{cTnT}$ or $\mathrm{cTnI}$ as late marker would be the ideal combination to cover the complete diagnostic window for AMI. A new approach to detect myocardial injury more rapidly is to increase the frequency of blood sampling by measuring H-FABP both in the admission sample and $1 \mathrm{~h}$ after admission. Several studies showed that the rise in H-FABP plasma concentration, even below clinical reference value, already indicates the progression of an AMI. This sensitive detection of myocardial injury by H-FABP may also be applied in patients with unstable angina and chronic heart failure and here $\mathrm{H}$ FABP outperforms troponin due to its high tissue content and low normal value.

In Chapter 3 the development of a rapid and sensitive immunoassay for human H-FABP is described. This assay is based on the use of high affinity monoclonal capture and detector antibodies (mAbs) recognizing different epitope groups on the protein molecule. 
The simultaneous incubation of the tissue/plasma/serum sample with the (immobilized) capture antibody and the (conjugated) detector antibody, allowed a total performance time of only $45 \mathrm{~min}$. The low intra- and inter-assay variation and detection limit of the assay permit an accurate determination of H-FABP in healthy individuals as well as the detection of micro-necrosis in patients with unstable angina or heart failure (see below). The measuring range (at 25 -fold dilution) of up to $300 \mu \mathrm{g} / \mathrm{L}$ includes $>90 \%$ of reported H-FABP concentrations in AMI. As a result, the immunoassay is excellently suitable for determination of H-FABP in blood from patients entering the coronary care unit of the hospital for the early assessment or exclusion of myocardial injury.

Because fatty acid metabolism is an important subject of research, Chapter 4, evaluates the applicability of the human H-FABP ELISA in different animal studies. Crossreactivity of the selected $\mathrm{mAbs}$ was measured with recombinant and purified H-FABPs from different species. The assay was then applied in tissue and plasma samples to study either fatty acid metabolism or the use of H-FABP as diagnostic marker for heart and skeletal muscle injury. The mAbs recognize H-FABP in most species tested, with the exception of duck, woodpigeon and chicken. Cross-reactivity compared to purified human H-FABP ranged from 5\% to $66 \%$ among horse, dog, cattle, mouse, rat and goose. Variations in H-FABP tissue content, due to changes in fatty acid metabolism, were induced by development, hibernation, extensive flight, and streptozotocin induced diabetes. Diagnostic use of H-FABP as plasma marker was shown for skeletal muscle injury in racehorses and for detection of experimental myocardial injury in mice.

From these studies it was can concluded that H-FABP is a well-conserved protein during evolution and the newly developed immunoassay for human H-FABP can be applied for several animal model systems, because cross-reactivity of the monoclonal anti-human $\mathrm{H}$ FABP antibodies in different species is rather high.

In order to investigate the clinical application of a new biochemical marker, first a reference range and a reference value (also termed cut-off value or upper reference limit) need to be established so as to properly compare different studies and interpret clinical data. In Chapter 5, the influence of age, sex and biological variation on normal plasma $\mathrm{H}$ $\mathrm{FABP}$ and $\mathrm{Mb}$ concentrations in healthy individuals is extensively evaluated.

Median plasma concentrations of H-FABP and Mb were significantly lower in women than in men, but showed an increase during aging. This effect of aging was more prominent in the plasma concentration of H-FABP than that of Mb. For the within-day biological variation, a significant increase was seen in H-FABP plasma concentration during the night. This effect was due to a decreased nocturnal glomular filtration rate. The same trend was seen for Mb but this did not reach statistical significance. Time of day, age and sex do influence the reference value of both H-FABP and Mb. From these data, we suggest an upper reference value of $6 \mu \mathrm{g} / \mathrm{L}$ for $\mathrm{H}-\mathrm{FABP}$ and $60 \mu \mathrm{g} / \mathrm{L}$ for $\mathrm{Mb}$.

In Chapter 6 we compared the sensitivity, specificity and prognostic value of H-FABP and cTnT for minor myocardial injury during CHF and UAP.

Admission plasma samples were obtained from 62 patients with CHF and 23 patients with UAP. According to plasma concentrations of H-FABP and cTnT, patients were subdivided into four groups. In CHF, plasma cTnT was elevated in 28 patients, while plasma H-FABP was elevated in 42 patients. Interestingly, only 3 patients had a normal H-FABP level together with an elevated cTnT level, while 17 patients showed 
increased plasma H-FABP, despite a normal plasma cTnT concentration. These 17 patients $(29 \%)$ would normally not be treated as having myocardial injury. This finding was confirmed in the group with UAP, where 6 patients $(26 \%)$ had elevated H-FABP levels with normal cTnT levels. Kidney function did not influence the relative differences between H-FABP and cTnT for detection of myocardial injury.

When we compared the prognostic value of both markers for the prediction of recurrent cardiac events within 90 days, H-FABP had a significantly better negative predictive value than cTnT. Patients with plasma H-FABP concentration below the reference value had $19 \%$ chance of a recurrent cardiac event, while patients with a plasma cTnT below the reference value had a $43 \%$ chance of a recurrent cardiac event. Taken together, in this chapter we show that $(i)$ minor myocardial cell necrosis is detectable in a significant proportion of patients with CHF, (ii) H-FABP is a more sensitive marker for detection of minor myocardial injury than cTnT, (iii) H-FABP is a significantly better prognostic marker than $\mathrm{cTnT}$.

H-FABP is also expressed, although to a lower extent, in skeletal muscle. In Chapter 7, we evaluated $\mathrm{H}-\mathrm{FABP}, \mathrm{Mb}$ and creatine kinase (CK) as plasma marker for the early detection of exercise induced skeletal muscle injury after 20 min of downhill running, which is known to induce eccentric muscle injury. $\mathrm{Mb}$ and $\mathrm{H}-\mathrm{FABP}$ concentrations were already significantly elevated at $30 \mathrm{~min}$, but CK not until $2 \mathrm{~h}$ after exercise. Whereas plasma $\mathrm{Mb}$ and $\mathrm{H}-\mathrm{FABP}$ decreased to normal levels within $24 \mathrm{~h}$, CK activity remained elevated for $48 \mathrm{~h}$. The $\mathrm{Mb}$ over $\mathrm{H}-\mathrm{FABP}$ ratio in plasma after exercise was 15 , which excludes H-FABP release from myocardial injury. In this chapter we show that both $\mathrm{H}-$ FABP and $\mathrm{Mb}$ are more useful than $\mathrm{CK}$ for the early detection and monitoring of injury during repeated exercise bouts. In addition, the Mb over H-FABP ratio in the plasma identifies the type of muscle injured.

Continuing further exploring the application of H-FABP as tissue injury marker, we turned to the field of kidney injury by evaluating (i) nephrotoxicity and (ii) ischemic injury of non-heart-beating donor (NHBD) kidneys.

In Chapter 8 , kidney injury is evaluated in rats, induced either by administration of mercuric chloride, cyclosporin or gentamicin. Histopathology and urine marker concentrations clearly indicate that mercuric chloride induced a broad nephrotoxic effect, while cyclosporin induced a modest damage primarily to the ascending and distal tubules.

Gentamicin administration induced relatively the most severe injury as indicated by significantly elevated urinary levels of LDH, total protein, H-FABP and GST. Damage to the proximal convoluted tubules was shown by significantly elevated urinary levels of $\alpha$-GST. Other more distal regions of the nephron were also affected as shown by severely elevated levels of H-FABP and $\mu$ GST.

This chapter shows that the patterns of urinary markers are different for the three nephrotoxins used in this study and that these patterns appear to reflect the location and degree of injury. Both plasma and urinary H-FABP levels are suitable markers for detection of kidney distal tubular injury. In future studies, next to H-FABP, it would be of interest to study L-FABP as marker for detection of injury to the proximal kidney tubules because this protein is located in the proximal tubular cells.

In Chapter 9, we studied the use of H-FABP as viability marker for ischemic injured NHBD kidneys. Alanine amino-peptidase (Ala-AP) and H-FABP were investigated as 
alternative biochemical tissue injury markers to total GST activity (tGST) in tissue perfusate samples from 74 kidneys from controlled (intensive care department; withdrawal of treatment) and uncontrolled (accident and emergency department) NHBDs. During perfusion, a parallel response was seen for each of the three markers in the perfusates of controlled and uncontrolled NHBD kidneys over the 4-h perfusion period. The levels of all markers were significantly higher in uncontrolled versus controlled donors and in discarded versus transplanted kidneys. Unfortunately, no correlation was found between pre-transplant biomarker concentrations and long-term renal function, as determined by creatinine clearance rate.

In this chapter we show that tGST, Ala-AP and H-FABP represent comparable pre-transplant indicators of immediate kidney viability and short-term kidney-function, with H-FABP tending to be the most sensitive marker. Although the biomarkers do not predict the efficacy of renal function in the longer term, the use for short-term screening of kidney function does lead to a survival rate of NHBD kidneys which is sufficient to serve as an important source to match the increasing waiting lists.

Another type of FABP with multiple tissue expression is L-FABP. This protein is abundantly expressed in liver and is rapidly released from damaged hepatocytes. In Chapter 10, we compared serum L-FABP with GST and ALT as markers for the early detection of hepatocellular damage associated with acute rejection episodes in a population of liver transplant recipients. A reference range and reference value for LFABP in plasma were established in a healthy donor population and showed no age or sex differences. In contrast, a circadian rhythm with elevated early morning levels was observed.

Routine daily samples from liver transplant recipients, who had sustained episodes of acute allograft rejection, showed that a significant $(>50 \%)$ increase in serum L-FABP concentration occurred in association with all acute rejection episodes, whereas $\alpha$-GST increased in $95 \%$ and ALT in $76 \%$ of all episodes. L-FABP increased on average 1.0 day earlier than serum ALT and on average 0.3 days earlier than $\alpha$-GST. L-FABP increased on average 1.5 days earlier than the day treatment was started.

These novel data are the first application of L-FABP as a sensitive means of detecting acute hepatocellular damage with comparable sensitivity as $\alpha$-GST, currently regarded the most sensitive biochemical marker of acute liver injury.

Intestinal-type fatty acid-binding protein (I-FABP) has been proposed as plasma marker for the detection of acute intestinal injury. However, intestinal mucosa also expresses LFABP. In Chapter 11, the tissue distribution of I-FABP and L-FABP is investigated in segments of the human intestine along the duodenal to colonal axis and the potential of both proteins to serve as plasma marker for the diagnosis of intestinal injury is studied. FAT/CD36 was measured to compare membrane fatty acid uptake with the cytoplasmic fatty acid transport proteins. Plasma reference values were established in normal healthy individuals.

We show a similar pattern of tissue distribution of I-FABP, L-FABP, H-FABP and FAT/CD36 along the duodenal to colonal axis with highest tissue contents found in the jejunum but in each intestinal segment a $>40$-fold higher content of L-FABP than of I-FABP. Accordingly, besides I-FABP, also L-FABP is a useful plasma marker for the detection of intestinal injury, especially in patients undergoing intestinal surgery. 
The latest development in the clinical utility of FABP is the detection of brain injury. In Chapter 12., we have investigated the tissue distribution of B-FABP and H-FABP in segments of the human brain and the potential of either protein to serve as a plasma marker for the diagnosis of brain injury. B-FABP and H-FABP were measured in autopsy samples of the brain, and in serum samples from patients with mild traumatic brain injury and depressed patients undergoing bilateral electroconvulsive therapy. The marker proteins S100B and NSE were measured for comparison. Reference values of B-FABP and H-FABP were established in normal healthy individuals.

In this chapter we show that B- FABP and H-FABP have a different pattern of tissue content with highest contents found in the frontal lobe and pons, respectively. However, in each part of the brain, the content of H-FABP is at least 10 times higher than that of B-FABP. The patient studies indicate that B-FABP and H-FABP are more sensitive markers for minor brain injury than the currently used markers S100B and NSE.

In Chapter 13 of this thesis, we present a general discussion on the use of FABP as serum/plasma marker for the detection of tissue injury. Rapid release from damaged cells and diffusion into the circulation make FABP a prominent early marker. Especially the combination of their high concentration tissue contents and low normal plasma values provides the possibility of a rapid rise above the respective reference values and, thus, an early indication of the appearance of tissue injury. However, improvement of patient treatment by measuring early biochemical markers requires their rapid analysis in plasma by point-of-care testing. Here bedside testing by handhold devices or decreased measurement time by more rapid test-systems would allow a more rapid identification of the patient status, which is important especially in the field of acute coronary syndromes.

Future research on the clinical utility of FABP mainly should focus on three aspects. First, prognostic value. Especially in patients with chronic heart failure, in which continuous low-grade cell damage is reported, H-FABP shows a significant better negative predictive value than cTnT for the appearance of recurrent events (see Chapter 6). Second, serial measurements of marker proteins will increase the sensitivity and specificity of the markers as a relative increase, independent of absolute plasma values, already can indicate tissue injury, even when plasma values are below the reference value. This observation will allow the clinician to start treatment as early as possible, which is not only important for myocardial injury (see Chapter 2), but also for detection of rejection injury of kidney- or liver transplants, intestinal diseases and brain injury due to stroke or mild trauma. The third focus is to effectively monitor the plasma values of biochemical markers and to allow serial measurements by on-line monitoring. Changes in the release pattern of FABP in the patient plasma can be measured with biosensors, allowing not only detection of tissue injury, but also estimation of the extent of damage, monitoring patients who are prone to develop tissue injury and for risk stratification.

As a final conclusion of this thesis we would like to state that the application of FABP as tissue injury marker has great potential for many clinical purposes. 


\section{Samenvatting}

Het terugdringen van niet alleen de morbiditeit en mortaliteit, maar ook van ziekenhuiskosten, zijn belangrijke doelstellingen in gezondheidszorgonderzoek. Een goede en snelle diagnose van de status van een patiënt, hetzij door de huisarts, of in het ziekenhuis, is daarom belangrijk. Behalve anamnese en medisch verleden, worden bloedparameters hierbij steeds belangrijker. Vooral bij de beoordeling van patiënten met acute weefselschade, zijn zogenaamde biochemische markers belangrijke diagnostische en vaak ook prognostische parameters gebleken. Omdat in het algemeen geldt dat een eerder gestarte behandeling leidt tot minder weefselschade, 'tijd spaart weefsel', zal sneller aantonen van weefselschade door middel van routinematig gebruik van biochemische markers, resulteren in een betere behandeling van de patiënt, en uiteindelijk een verminderde morbiditeit en mortaliteit. Tevens zullen ziekenhuiskosten verminderen omdat patiënten met niet ziekte-gerelateerde klachten veilig naar huis kunnen.

Een van de veelbelovende nieuwe markers voor het aantonen van weefselschade is het cytoplasmatisch vetzuurbindend eiwit (in het Engels fatty acid-binding protein, afgekort FABP $)$. Dit relatief kleine $(15 \mathrm{kD})$ eiwit is betrokken bij het metabolisme van langketenige vetzuren en komt in overmaat voor in weefsels met een actief vetzuurmetabolisme, zoals hart en lever. Na het optreden van celschade, komen cellulaire eiwitten in het interstitium terecht, en zullen daarna diffunderen door openingen in het endotheel, waarna ze in de bloedbaan terechtkomen. Omdat deze openingen in het endotheel qua grootte verschillen, kunnen kleine eiwitten zoals FABP sneller door de vaatwand diffunderen dan grote eiwitten, en verschijnen hierdoor dus ook sneller in de bloedbaan.

In dit proefschrift wordt de toepassing beschreven van verschillende typen FABP voor het aantonen van weefselschade bij patiënten met een acuut myocard infarct (AMI), chronisch hartfalen, onstabiele angina, skeletspierschade, nier-toxiciteit en niertransplantatie, levertransplantatie, darmschade of hersenschade, zoals in het kort in hoofdstuk 1 is weergegeven.

Hoofdstuk 2 geeft een overzicht van de huidige status van verschillende FABP-typen, in vergelijking met huidige bloedmarkers, voor het specifiek meten van weefselschade. Verder worden in dit hoofdstuk de ontwikkeling van assays, point-of-care testen, en klinische studies geëvalueerd. Vooral op het gebied van hartschade is gebleken dat het hart-type FABP (H-FABP) de meest vroege marker is voor het aantonen van een AMI. Binnen 6 uur na het optreden van klachten, is H-FABP significant specifieker en gevoeliger dan de momenteel gebruikte vroege marker myoglobine $(\mathrm{Mb})$. Omdat de cardiale troponines $\mathrm{T}(\mathrm{cTnT})$ en I (cTnI) specifiek zijn maar relatief laat (na ongeveer 6 uur) een infarct kunnen bevestigen of uitsluiten, zou één van deze troponines samen met H-FABP een ideale combinatie vormen om het zogenoemde 'diagnostic window' van AMI te dekken. Om hartschade snèller te kunnen aantonen zou men vaker bloed kunnen afnemen, bijvoorbeeld bij binnenkomst en 1 uur na binnenkomst van de patiënt. Verschillende studies hebben aangetoond dat een stijging van de plasma concentratie van 
H-FABP, zelfs indien geen van de concentraties boven de klinische referentie waarde uitstijgt, al een beginnend infarct aan kan geven.

In hoofdstuk 3 wordt de ontwikkeling van een snelle en gevoelige immunoassay (ELISA) voor de bepaling van humaan H-FABP beschreven. Deze assay is gebaseerd op het gebruik van hoogaffine monoklonale catcher- en detector antilichamen die verschillende epitopen op het eiwit molecuul herkennen. Door gelijktijdige incubatie van het te onderzoekn monster (weefsel, serum/plasma) met het plaatgebonden catcher antilichaam en het gelabelde detector antilichaam, is een assaytijd van slechts 45 min mogelijk. De lage intra- en interassay variatie en de lage detectielimiet van de assay maken een nauwkeurige bepaling mogelijk van H-FABP bij zowel gezonde individuen (normaal waarde), als bij patiënten met onstabiele angina (UAP) of chronisch hartfalen (CHF) (micronecrose, zie hierna). Het meetbereik (bij een 25-maal verdunning) tot $300 \mu \mathrm{g} / \mathrm{L}$ omvat $>90 \%$ van alle gerapporteerde H-FABP concentraties in AMI patiënten. Daarom is deze immunoassay uitermate geschikt voor de kwantificering van H-FABP in bloed van patiënten die de Eerste Hart Hulpvan een ziekenhuis binnenkomen, waarbij hartschade bevestigd dan wel uitgesloten moet worden.

Omdat het vetzuurmetabolisme een belangrijk onderwerp van onderzoek is,wordt. in hoofdstuk 4 de toepasbaarheid van de humane H-FABP ELISA bekeken in verscheidene proefdierenstudies. De kruisreactiviteit van de geselecteerde monoklonale antilichamen werd gemeten met behulp van recombinante- en gezuiverde H-FABP's van verschillende diersoorten. De assay werd toegepast op weefsel en plasma monsters om ofwel het vetzuurmetabolisme, ofwel het gebruik van H-FABP als diagnostische marker voor harten skeletspierschade te onderzoeken. De monoklonale antilichamen herkennen H-FABP in het gros van de onderzochte diersoorten, behalve bij de eend, houtduif en kip. Vergeleken met gezuiverd humaan H-FABP varieerde de kruisreactiviteit van 5\% tot $66 \%$ tussen paarden, honden, rundvee, muizen, ratten en ganzen. Variaties in de weefselinhoud van H-FABP, door veranderingen in vetzuurmetabolisme, waren het gevolg van verschillen in ontwikkelingsstadium, winterslaap, lange-afstands vluchten, en ziekten (bv. diabetes). Het diagnostische gebruik van H-FABP als plasma marker voor skeletspierschade werd aangetoond in racepaarden, en voor het aantonen van experimenteel geïnduceerde hartschade in muizen. Uit dit onderzoek werd geconcludeerd dat H-FABP tijdens de evolutie goed geconserveerd is, en dat de nieuw ontwikkelde immunoassay voor H-FABP voor verschillende diermodellen bruikbaar is.

Om de toepasbaarheid van een nieuwe biochemische marker te kunnen bepalen, moet allereerst een referentiebereik en een referentiewaarde (ook wel cut-off waarde of upper reference waarde genoemd) worden bepaald. Zo kunnen ook verschillende studies en de daarbij behorende klinische gegevens correct vergeleken en geïnterpreteerd worden. In hoofdstuk 5 wordt de invloed van leeftijd, geslacht en biologische variatie op de normale $\mathrm{H}-\mathrm{FABP}$ en $\mathrm{Mb}$ plasmawaarden in gezonde individuen bestudeerd.

De gemiddelde plasmawaarden van beide markers zijn significant lager in vrouwen dan in mannen. Verder bleek dat de plasma concentratie van de markers hoger werd bij een toename van de leeftijd, en dat dit effect meer prominent was bij H-FABP dan bij Mb. Voor de variatie binnen één dag werd een significant verhoogde H-FABP plasma concentratie gedurende de nacht aangetoond. Dit effect wordt toegeschreven aan een verminderde glomulaire filtratiesnelheid. Dezelfde trend werd gevonden voor $\mathrm{Mb}$, 
maar hier was geen sprake van statistisch significante verschillen. De tijd van de dag, leeftijd en geslacht beïnvloeden de referentie waarde van zowel H-FABP als Mb. Naar aanleiding van deze data stellen we een referentie waarde voor van $6 \mu \mathrm{g} / \mathrm{L}$ voor $\mathrm{H}-\mathrm{FABP}$ en $60 \mu \mathrm{g} / \mathrm{L}$ voor $\mathrm{Mb}$.

Het gebruik van H-FABP in vergelijking met cTnT voor het aantonen van minimale hartschade in patiënten met CHF en UAP wordt beschreven in hoofdstuk 6. Recente studies tonen aan dat progressieve verslechtering van de kamerfunctie in patiënten met CHF geassocieerd kan worden met het optreden van continue hartschade. Veel patiënten met CHF of UAP kunnen echter niet goed worden gediagnostiseerd omdat de huidige biochemische plasma markers niet gevoelig genoeg zijn.

Bij 62 patiënten met CHF en bij 23 patiënten met UAP werden bij binnenkomst bloedmonsters genomen. Naar aanleiding van de daarin gemeten H-FABP en cTnT plasma concentraties, werden de patiënten onderverdeeld in vier groepen. Bij de CHF patiënten was plasma cTnT in 28 patiënten verhoogd, terwijl plasma H-FABP verhoogd was in 42 patiënten. Belangrijk is dat slechts 3 patiënten een normaal H-FABP en een verhoogde cTnT waarde hadden, terwijl 17 patiënten (27\%) een verhoogde H-FABP met een normale cTnT plasma concentratie hadden. Deze $27 \%$ zou doorgaans niet behandeld worden voor hartschade. Dit resultaat werd ook gevonden in de groep van UAP patiënten, waar 6 patiënten $(26 \%)$ een verhoogde H-FABP concentratie gecombineerd met een onveranderde cTnT waarde hadden. Dit verschil tussen H-FABP en cTnT voor het aantonen van geringe hartschade werd niet beïnvloed door de nierfunctie.

Bij het vergelijken van de prognostische waarde van beide markers voor het voorspellen van nieuwe hartproblemen binnen 90 dagen, bleek dat H-FABP een significant betere negatief voorspellende waarde had dan cTnT. Patiënten met een $\mathrm{H}-$ FABP plasma concentratie onder de referentie waarde hadden $19 \%$ kans om opnieuw hartklachten te krijgen, terwijl patiënten met een cTnT plasma waarde onder de referentie waarde deze kans $43 \%$ was. Samengevat blijkt dat (i) geringe hartschade aantoonbaar is in het meerendeel van de patiënten met CHF, (ii) H-FABP, ten opzichte van cTnT, een gevoeligere marker is voor het aantonen van deze hartschade, (iii) H-FABP een significant betere prognostische marker is dan cTnT.

Omdat H-FABP, alhoewel in mindere mate, ook tot expressie komt in skelet spieren, hebben we in hoofdstuk 7 onderzocht of H-FABP ook bruikbaar is voor het vroeg aantonen van skeletspierschade. Plasma concentraties van H-FABP, Mb en creatine kinase $(\mathrm{CK})$ werden gemeten in gezonde sportdocenten na een 20 minuten durende looptest, die excentrische spierschade veroorzaakt. Mb en H-FABP waren binnen 30 minuten significant verhoogd in plasma, terwijl CK pas 2 uur na de training verhoogd was. De Mb en H-FABP concentraties bereikten weer normale waarden binnen 24 uur, terwijl de CK waarden verhoogd bleven gedurende 48 uur. De verhouding van $\mathrm{Mb}$ over $\mathrm{H}-\mathrm{FABP}$ in plasma bedroeg 15 hetgeen uitsluit dat H-FABP afkomstig is uit de hartspier. In dit hoofdstuk hebben we aangetoond dat zowel Mb als H-FABP beter bruikbaar zijn dan $\mathrm{CK}$ voor het snel aantonen en monitoren van schade geïnduceerd door fysieke training. Bovendien geeft de verhouding van $\mathrm{Mb}$ over H-FABP aan welk spiertype beschadigd is. 
In de speurtocht naar verdere toepasbaarheid van H-FABP als marker voor weefsel schade, werd het veld van nierschade betreden. Zowel de niertoxiciteit als de ischemische schade bij non-heart-beating donor (NHBD) nieren werden geëvalueerd.

Hoofdstuk 8 beschrijft de studie waarin aan ratten kwikchloride, cyclosporine of gentamicine werd toegediend. Histopathologie en urine concentraties van glutathion-Stransferase, totaal eiwit, en van lactaat dehydrogenase toonden aan dat kwikchloride vooral in het distale deel van de tubulus schade had veroorzaakt. Ook werd de nierfunctie sterk beïnvloedt, wat bleek uit een toegenomen urine volume (verminderde water opname, verhoogde creatinine- en ureum plasmawaarden). Distaal gelegen H-FABP was niet verhoogd in de urine; wellicht komt H-FABP eerder in de bloedbaan terecht dan in urine. Helaas waren er geen bloedmonsters beschikbaar om deze hypothese te bevestigen.

Bij cyclosporine bleek dat de schade in eerste instantie vooral in het distale deel van de tubulus was toegebracht. Dit werd bevestigd door een sterke toename van de urinewaarden van het distaal gelocaliseerde $\mu$-GST. Distaal gelegen H-FABP was verminderd in urine na behandeling van cyclosporine, wat veroorzaakt kan worden door een veranderde uitstortroute, zoals eerder gesuggereerd. De door cyclosporine geïnduceerde nierschade bleek gering (relatief weinig toename in plasma ureum concentratie en urine volume).

Gentamicine gaf de meeste nierschade, aangetoond door de significant verhoogde urinewaarden van LDH, totaal eiwit, H-FABP en GST. De hoge $\alpha$-GST concentratie in urine geeft schade aan de proximale tubulus aan. Andere meer distaal gelegen delen van de nieren waren ook beschadigd, aangetoond door sterk verhoogde waarden van H-FABP en $\mu$-GST.

Dit hoofdstuk geeft aan dat de patronen van urine markers verschillen tussen de drie toxines, en dat de patronen de localisatie en mate van schade aangeven. Zowel plasma als urinewaarden van H-FABP zijn geschikte parameters voor de detectie van nierschade aan de distale tubulus. In toekomstige studies zou het L-FABP als proximale schade marker bestudeerd kunnen worden.

In hoofdstuk 9, staat de studie beschreven waarin het gebruik van H-FABP als viabiliteits marker voor ischemische NHBD nieren wordt bestudeerd. Gedurende machine perfusie van NHBD nieren wordt door middel van flow karakteristieken en ischemie markerwaarden de viabiliteit van deze waardevolle bron van transplantatie nieren onderzocht.

Alanine amino-peptidase (Ala-AP) en H-FABP werden vergeleken met totale GST activiteit (tGST) in perfusaat monsters van 74 nieren van gecontroleerde (intensive care afdeling, behandeling gestopt) en ongecontroleerde (ongeluk en eerste hulp) NHBDs. Tijdens de 4 uur durende perfusie vertoonden de drie bovengenoemde markers een vergelijkbaar verloop bij beide typen nieren. Alle markerwaarden waren in de nietgecontroleerde groep significant hoger dan in de gecontroleerde groep, en ook in de nietversus wel transplanteerbare nieren. Een significante correlatie werd gevonden tussen tGST, Ala-AP en H-FABP. Er werd echter geen correlatie gevonden tussen markerconcentraties voor de transplantatie en de nierfunctie op lange termijn, welke bepaald kan worden door de snelheid van creatinineklarings.

In dit hoofdstuk beschrijven we tGST, Ala-AP en H-FABP als zijnde vergelijkbare parameters voor het bepalen van directe nier-viabiliteit en de nierfunctie op korte termijn. Hierbij lijkt H-FABP de meest gevoelige marker te zijn. Alhoewel de markers niet de efficiëntie van de nierfunctie op de lange termijn kunnen voorspellen, 
lijdt een screening van de nierfunctie op korte termijn tot een verbeterde overlevingskans van NHBD nieren, zodat op deze manier het probleem van groeiende wachtlijsten aangepakt zou kunnen worden.

Een ander type FABP dat in meerdere weefsels tot expressie komt is het L-FABP. Dit eiwit is in overmaat aanwezig in de lever en komt snel vrij bij schade aan levercellen. In hoofdstuk 10 beschrijven we de studie waarin serum L-FABP wordt geëvalueerd als marker voor het aantonen van levercelschade in relatie met afstotingsperioden bij transplantatie patiënten. De gevoeligheid van L-FABP werd vergeleken met de huidige markers $\alpha$-GST en alanine aminotransferase (ALT). Een referentiebereik en referentiewaarde voor L-FABP werd bepaald in een gezonde donorpopulatie, waaruit bleek dat er geen verschillen waren tussen leeftijd en geslacht. Het circadische ritme bleek wel te verschillen, in de nacht werden namelijk verhoogde waarden gemeten.

Uit de dagelijkse samples van transplantatie patiënten met biopt bevestigde acute afstotingsreacties geanalyseerd bleek dat L-FABP serum concentratie significant $(>50 \%)$ verhoogd was tijdens alle afstotings episoden, terwijl $\alpha$-GST tijdens $95 \%$ van de episoden en ALT in 76\% van alle episoden verhoogd was. L-FABP was gemiddeld 1.0 dag eerder verhoogd dan ALT en gemiddeld 0.3 dagen eerder dan $\alpha$-GST. L-FABP was gemiddeld 1.5 dag eerder verhoogd, dan de dag waarop de behandeling werd gestart.

Deze studie geeft voor het eerst de toepasbaarheid aan van L-FABP als gevoelige marker voor acute levercelschade.

Het intestinaal-type, I-FABP, zou een marker kunnen zijn voor het aantonen van acute darmschade, ware het niet dat ook L-FABP in de darmwand tot expressie komt. Daarom is er gekeken naar de weefselverdeling van I- en L-FABP in segmenten van de humane darm van duodenum naar colon (zie hoofdstuk 11). Verder werd de mogelijke functie van beide eiwitten als plasma marker voor de diagnose van darmschade bestudeerd. Het plasmamembraaneiwit vetzuurtranslocase (FAT/CD36) werd gemeten om de vetzuuropname te kunnen vergelijken met de localisatie van cytoplasmatische vetzuurtransporteiwitten. Plasma referentiewaarden werden bepaald in gezonde individuen.

$\mathrm{Er}$ is een vergelijkbare weefselverdeling van I-FABP, L-FABP, H-FABP en FAT/CD36, van duodenum naar colon, met de hoogste waarde in het jejunum, maar voor L-FABP geldt dat deze waarde ten opzichte van het I-FABP $>40$ keer hoger is. Tevens concluderen we dat naast I-FABP, ook het L-FABP gerekend kan worden tot een geschikte plasma marker voor de detectie van darmschade.

De laatste ontwikkeling op het gebied van klinische toepasbaarheid van FABP is het aantonen van hersenschade (hoofdstuk 12). Alhoewel het gebruik van serum markers bij hersenschade nog niet een standaard klinische methode is, zijn er wel enkele markers bekend die als zodanig gebruikt zouden kunnen worden, namelijk S100B, neuron specifiek-enolase (NSE), myeline basaal eiwit, en het glial fibrillaire eiwit. Wij hebben de weefselverdeling van B-FABP en H-FABP in verschillende delen van de hersenen onderzocht, en de klinische toepasbaarheid bij hersenschade. Beide eiwitten werden gemeten in autopsiemonsters, in serum monsters van patiënten met milde hersenschade en van depressieve patiënten die bilaterale electroconvulsieve therapie ondergingen. Ter vergelijking werden ook de markereiwitten S100B en NSE gemeten. Referentiewaarden voor B-FABP en H-FABP werden bepaald in gezonde individuen. 
Verschillende weefselwaarden van het B-FABP en H-FABP werden gevonden in de frontale-, temporale-, occipitale kwab, striatum, pons en cerebellum, waarbij de weefselwaarde H-FABP significant hoger was dan van B-FABP. B-FABP was niet aantoonbaar in het serum van gezonde individuen. Bij $68 \%$ van de patiënten met milde hersenschade waren de B-FABP serumwaarden verhoogd en in $70 \%$ van deze patiënten was het H-FABP verhoogd. S100B was slechts in $45 \%$ en NSE in $51 \%$ van deze patiënten verhoogd. In de studie betreffende de electroconvulsieve therapie was B-FABP in $6 \%$ van alle samples verhoogd, en H-FABP in $17 \%$ van alle samples. S100B was slechts in $0.4 \%$ van alle samples in deze studie verhoogd.

Uit bovengenoemde studies blijkt dat zowel B-FABP als H-FABP gevoeliger markers zijn voor hersenschade dan S100B en NSE.

In hoofdstuk 13, wordt de algemene discussie weergegeven over het gebruik van FABP als serum/plasma marker voor het aantonen van weefselschade. Snelle uitstort vanuit beschadigde cellen en snelle diffusie naar de circulatie maken van FABP een veelbelovende marker.

De kwaliteiten van een vroege marker zijn afhankelijk van de kwantificeringsmethode. Een snelle analyse verbetert namelijk de mogelijkheid tot behandeling van een patiënt. 'Bedside' testen en snelle testsystemen verkorten de meettijd, waardoor het diagnostiseren van de patiënt versneld kan worden, wat vooral van belang is bij mensen met acute coronaire syndromen.

Vervolgonderzoek naar de klinische toepasbaarheid van FABP zal zich grotendeels richten op drie aspecten. Ten eerste op de prognostische waarde van FABP. Uit de hartfalenstudie (hoofdstuk 6), bleek al dat H-FABP een betere voorspellende waarde had dan het cTnT. Ten tweede zullen opeenvolgende metingen van markereiwitten in de bloedbaan de sensitiviteit en specificiteit van een marker vergroten. Onafhankelijk van de plasmawaarde op zich, kan een stijging van de concentratie onder de referentiewaarde al een indicatie zijn van zich ontwikkelende schade. Dit stelt een arts in staat de behandeling eerder te starten. Ten derde zou het onderzoek gericht moeten zijn op het continue kunnen meten van de markers met biosensoren. Hierdoor is niet alleen het snel aantonen van schade mogelijk, maar kan er ook een schatting gemaakt worden van de hoeveelheid schade, en bestaat er de mogelijkheid tot het monitoren van patiënten die een vergroot risico hebben op het ontwikkelen van weefselschade.

Naar aanleiding van het onderzoek beschreven in dit proefschrift concluderen we dat voor diverse klinische doelen het gebruik van FABP als marker van weefselschade van grote waarde zal zijn. 


\section{Dankwoord}

Promoveren is te vergelijken met het schieten van een pijl. Een goede voorbereiding, het juiste materiaal, en doelgericht werken zijn onontbeerlijk. Alhoewel je in beginsel alleen verantwoordelijk bent voor je schot, is de samenwerking in een team vaak net die extra stimulans om te kunnen gloreren. Zonder samenwerking zou ook dit proefschrift veel moeilijker tot stand zijn gekomen. In dit dankwoord wil ik daarvoor iedereen (en dat zijn er velen) bedanken.

Natuurlijk eerst mijn promotoren. Beste Jan, de vrijheid die je me hebt geboden om al het onderzoek te kunnen doen is een enorme stimulans geweest om dit proefschrift te schrijven. Voor eigen onderzoek, nieuwe technieken, cursussen, presenteren en publiceren kon ik altijd bij je binnenlopen. Je rode pen zal onlosmakelijk verbonden zijn met de quote dat het artikel vrijwel klaar is, op enkele kleine wijzigingen na. Ook op persoonlijk vlak waardeer ik je begrip voor de thuissituatie die ook op het werk merkbaar was. Bedankt voor alles.

Beste Wim, ook jou wil ik erg bedanken voor de goede persoonlijke contacten die we hebben gehad in de afgelopen jaren. Eerst met ellipsometrie, daarna als deskundige op het gebied van weefselschade. Je enthousiasme was kenmerkend toen ik je vroeg om copromoter te worden. Je kritische blik, uitstekende formuleringen en de relativerende kijk op allerlei zaken, hebben het onderzoek en dit proefschrift enorm vooruit geholpen.

Dan heb ik in de afgelopen jaren, zoals gezegd, met velen mogen samenwerken. Ik zal proberen om dit in een chronologische volgorde te plaatsen.

Allereerst Eduoard, Paul, Rob, Monica Galli en Edgar. Bedankt voor de heerlijke tijd bij Biochemie. Mariet en Trees, bedankt voor de vele "sociale" momenten. Daarnaast wil ik ook alle collega's van deze bloedstollende afdeling bedanken voor de fijne tijd. De bloedstolling heeft nog steeds mijn aandacht en zal via Daniëlle zeker uitgebreid worden.

Dan Fysiologie, hier heb ik veel collega's zien komen en gaan. Zeker de mensen in mijn naaste omgeving wil ik hier bedanken. Will Wodzig, het was een waar genoegen om samen onderzoek te doen, eerst als ELISA experts, daarna als latexdeskundigen! Markus was je opvolger en ook jou wil ik bedanken, samen met Ferenc en Mark. Ook Yvonne, Frans en Appie maakten het werk bij Fysiologie erg plezierig. Anita, Roy, Andries en Daniëlle maakten "de zuidkant" van fysiologie gezellig (sorry Daniëlle voor de screensavers van de mannen). Bij negen jaar Fysiologie horen zeer zeker ook Peter, Theo en Theo, Jodil, Frank, Joep, Karin, Danny, Kristel, Martijn, Jos, Karin, Claire, Linda, Richard, Marc, Luc, Ger, Mirjam, Frits en alle andere collega's van Microcirculatie, Chemische technologie en Electrofysiologie.

Faag display technologie was een zeer mooi uitstapje richting moleculaire genetica in combinatie met antilichaam onderzoek naar FAT/CD36. Met Henny Hoogenboom als inspirerende onderzoeksleider en Jan, Nicole, Jan Willem, Hans, Edith, Math, Peter en alle andere collega's van CESAME en pathologie was dit een inspirerende tijd. Hier heb ik mijn mooiste onderzoeksmoment beleefd. Een late vrijdagmiddag in de zomer op een 
vrijwel verlaten afdeling. Kleuren van je ELISA plaat met de eerste selecties van antilichamen op membraaneiwitten. Het oplichten van positieve klonen en de vrijwel lege kant met negatieve klonen betekende de eerste faag antilichamen tegen ons membraaneiwit en dat in slechts 2 maanden. Ongeloof en blijdschap wisselden zich af. Vrijdagmiddag is de tijd gebleken voor succesvolle experimenten.

Dan het FABP onderzoek. Met alle samenwerkingsverbanden en de zeer prettige FABP mini-workshops zijn er veel mensen die ik wil bedanken voor hun bijdrage aan het onderzoek in dit proefschrift.

Allereerst de Münster groep, bestaande uit Frits, Torsten, Göran, Thorsten, Rheinhard en zeer zeker Andrea. Ich habe mich sofort zuhause gefülhlt in euhre Gruppe und bin noch immer sehr beindruckt von euhre Untersuchungen im FABP bereich. Danke sehr fur die schone zeit in Münster (das Blaue Haus im Winter und den Biergarten im Sommer!)

Florian Guthmann (het Berlijnse anatomisch museum zal ik nooit meer vergeten), Lionel Clemont, Philippe Besnard, Helen Poitier en Isabelle Niot (Dyon heeft mijn mosterd smaak voorgoed veranderd), George Siegenthaler (zijn we in Geneve, is de fontein uit!) en natuurlijk de onvergetelijke Jean Paul Cader (het canton zingen bij het diner op de Eifeltoren was het "hoogtepunt" van alle FABP workshops, Qui Qui Qui, Non Non Non), zij allen maakten de discussies over FABP erg stimulerend.

Het project met HyCult biotechnology was uiteindelijk de start van dit proefschrift. Wim Buurman, jouw kennis en anekdotes van de immunologie en de wetenschap in het algemeen zijn onovertroffen. Gaby en Loek, na vele mails en bestellingen begint de FABP verkoop nu te lopen. Bedankt voor de fijne samenwerking.

Zonder interesse van klinische partners is het moeilijk als kleine groep klinische onderzoeken van de grond te krijgen. Echter, met Jaap Bakker en Paul Menheere is het laatste jaar een stroomversnelling geweest, heen en weer pendelend tussen hartfalen en hersenschade. Hoofdstuk 6 en 12 zijn aan jullie beiden opgedragen, zonder de mensen bij de hartfalen polie tekort te doen, want daar mocht ik altijd nieuwe patiënten bekijken. Ook Roland, Onno, en Marja wil ik bij deze erg bedanken. Het Euregio congres voor klinisch chemici was een inspiratie voor de toekomst. Ik hoop dat we nog veel mogen samenwerken.

Calum McNeil from the University of Newcastle Upon Tyne has been one of the inspiring people of the EUROCARDI trial and I would like to thank you for all your help and the wonderful time in Newcastle and in Hong Kong (I hope next time there is more beef). I also would like to thank Anna and Steve from Cambridge Life Sciences for the nice stay.

Rheinhard Renneberg and Helma Kaptein have made the time in Hong Kong one I will never forget. A totally different world, but still the same research. The horses, the races but most of all Hong Kong itself were wonderful. Thank you.

Alireza Morovat and Andrew Trull are the people that learned me a lot about liver injury. Cambridge is one of the most romantic places I have ever seen, full of life and beautiful 
university buildings. Thank you very much for your help. Someday, I hope to organize EMBODY II.

Johannes Mair and Stefan Sorichter helped me to evaluate H-FABP as marker for skeletal muscle injury, from marathons in Berlin and Hawaii, to "downhill" running in the lab. Vielen dank ihr beiden.

Jean Paul Chapelle (University Liège) en Marjon Knapen, bedankt voor de biologische variatie in dit proefschrift.

The gentlemen of Hoffmann-La Roche (Eisenwiener, Salud and Drees), thank you for the nice meetings on our FABP diagnostic research project.

Kristian Thygensen and Jan Ravkilde. Next time I visit Aarhus, I will stay away from green fish soup! Thank you for the myocardial injury work.

Pat Butler (University of Birmingham) and Ann Elise O Jordal (Norway Department of Fischeries) thank you for opening the new field of animal FABP research with migrating goose and Atlantic salmon. This is really basic and fun research.

Muhammed Gok from the Newcastle Transplantation Centre. You detect kidney injury as quick as you report on it. Thanks for the cooperation.

Dai Davis from Astra Zeneca. Kidney toxicity is a more complex proces than I thought. Thank you for your input in this thesis.

Zbigniew Namiot, Jan Gorski and all the other Polish doctors. It was an honour to be able to prepare together with you the pearl in the crown on your scientific work. I hope our FAT/CD36 data will be equally rated. Thank you very much.

Marja en Fanny, een treinreis van Maastricht naar Elsloo is zonder jullie nooit meer hetzelfde. Dankjewel.

Dan onze nieuwe groep, Moleculaire Genetica. Hier werden we bijzonder hartelijk ontvangen. Een jonge, uitstekende groep met enthousiaste mensen en veel nieuwe apparatuur. Beste Martin, Wilma, Lee, Anne, Ronit, Daniëlle, Menno, Marjon, Monique, Guillaume, Patrick, Arjan, Mathijs, Kristiaan, Petra, Hanneke, Celine, Vivian, Iris en Willem. Ik hoop dat we nog veel gezellige dagjes uit en koffie pauzes mogen hebben.

Als bijna laatste onze eigen group. Vetzuurmetabolisme is een proces van vele aparte factoren, die niet zonder elkaar kunnen functioneren. Jan, je professorschap kon op geen beter moment komen en geeft de kwaliteit van het onderzoek aan. Mister Joost, achter je "verstrooide" karakter schuilt een gedreven onderzoeker, wars van regeltjes en politiek. Debby, nog even doorzetten. Beste Susan, het gaat je lukken! Bedankt voor al je "buurt"minuutjes. Roy, na lang twijfelen nu eindelijk je toekomst gevonden. Onze tijd samen op de fysiologie kamer zal ik niet vergeten, ik zal proberen mijn toonhoogte met zingen en fluiten te verbeten. Je zult een goede combinatie tussen wetenschap, journalistiek en muziek vinden, dat weet ik zeker. Veel succes met je promotie verder. 
Dan mijn nieuwe kamergenoot Will. Oude rot in het vak, het is ... in nuth en hauwe veer mehr get te .he jung. Jouw zang kwaliteiten en de altijd aanwezige opgewektheid zijn een levendig onderdeel van het lab. Onze kamer aan het einde van de gang is klein en gezellig, laten we het zo houden.

Beste familie en vrienden, ik hoop dat jullie nu zien wat me vooral het laatste jaar zoveel tijd heeft gekost.

Piet en Anita, (onvergetelijke vakanties, zwoele zomer avonden, twinkelende kennedy mars en lange gesprekken), René en Nicole (carnaval, Frankrijk en grieken), Mark en Diana (nog een snoepje?), bedankt voor alles en dat we nog lang vrienden mogen zijn.

Pap en mam, jullie staan altijd voor me klaar, in voor- en tegenspoed. Ik hoop dat we nog vele dingen samen kunnen doen. Eric, nu je als paranimf naast me staat hoop ik dat je verlost bent van je afwas trauma en ziet dat mijn "studeren" na het eten toch nog nuttig is geweest. Marjolein, Frank, Toos en Danny. Ik ken geen gezin met een zo hoog doctor gehalte, helaas pas ik met mijn nog niet ontwikkelde bouwvakkers-capaciteiten er nog niet helemaal bij. Er wordt aan gewerkt.

Lieve Inge en Lars, het boekje van papa is nu ook klaar. Ik draag dit proefschrift op aan jullie beiden. Als het moeilijk was, waren jullie mijn inspiratie. Dat we samen een mooi leven mogen hebben, jullie verdienen het.

Lieve Daniëlle, jouw bijdrage aan dit proefschrift is enorm. Ben je net gepromoveerd, is er nog geen tijd voor vakantie. Vele uren heb je besteed aan de lay-out, figuren maken en het doorlezen van alle tekst. Het was bijna een tweede promotie voor je, zoveel heb ik aan je te danken. Van samenwerken naar samenwonen, het is niet niks. Toch deed je het. We vormen een goed team samen, zoals ook bij Technopartner bleek. Laten we inderdaad zo, saampjes en met zijn vieren, verder gaan. Op naar ons feest en vakantie, eindelijk. 


\section{Curriculum vitae}

De auteur van dit proefschrift, Maurice Pelsers, werd geboren in 1968 in het Limburgse Elsloo. Na het behalen van het Havo diploma in 1985, en het Atheneum diploma in 1987 aan de scholengemeenschap "Groenewald" te Stein, werd de keuze gemaakt voor de opleiding tot biochemisch analist aan de Hogere Laboratoriumschool te Sittard. Deze opleiding was perfect te combineren met het bedrijven van de handboogsport in de Nederlandse jeugdselectie. Hierdoor konden er meerdere buitenlandse toernooien, tot aan het EK toe, bezocht worden terwijl de medestudenten moesten zwoegen. Met de stage 'zuivering en lokalisatie onderzoek van L- $\alpha \mathrm{H}$ aminopeptidase in Pseudomonas putida' bij de toenmalige afdeling Bio-organische Chemie van DSM Research te Geleen werd de opleiding in 1991 afgerond.

In maart 1992 begon hij als research analist bij de afdeling Biochemie van de Universiteit Maastricht (toen nog Rijksuniversiteit Limburg geheten) aan het project "Anti-fosfolipiden antilichamen en de relatie met trombose". Daar werd de basis gelegd voor het opzetten en evalueren van immunoassays. Het ellipsometrie onderzoek naar de binding van anti-cardiolipine antilichamen aan de verschillende isovormen van $\beta_{2}$ glycoprotein was de eerste aanzet voor eigen onderzoek.

In 1994 volgde de overstap naar de afdeling Fysiologie waar een multicenter studie was gestart naar het gebruik van het eiwit FABP als vroege marker voor het aantonen van een acuut hart-infarct. Hier werden, naast alle klinische aspecten van onderzoek, op vele gebieden nieuwe technieken aangeleerd, waaronder biosensor- en faag-display technologie. Tevens werden hier de eerste stappen op het gebied van publiceren en presenteren gezet met een onderzoek naar het vetzuurmetabolisme in migrerende ganzen. In 1996 werd het onderzoek voortgezet in het project "Ontwikkeling van immunoassays met betrekking tot het quantificeren van nier-, lever- en darmschade", in samenwerking met HyCult Biotechnology te Uden. In 2001 nam het promotieonderzoek naar het gebruik van FABP als plasma marker voor het aantonen van weefselschade concrete vormen aan. Tevens werden er zijdelings taken verricht zoals de ontwikkeling van een immunoassay voor FAT/CD36 voor de bestudering van het vetzuurmetabolisme in diabetes en de ondersteuning bij de ontwikkeling van een on-line biosensor voor H-FABP.

$\mathrm{Na}$ vele immunoassays, AIO-cursussen, workshop- en congresbezoeken, klinische samenwerkingsverbanden, Biopartner ondernemers cursussen, Hong Kongse race paarden, Noorse zalmen en Canadese eekhoorns, werd dit proefschrift geschreven. De auteur zal zich na de verdediging hiervan verder gaan begeven op het pad der wetenschap, wellicht in combinatie met een Life Science ondernemerschap.

In de tussenliggende vrije tijd is Maurice meerdere malen Nederlands (team) en Limburgs (team en individueel) kampioen handboogschieten geworden en runt hij sinds 1998 een organisatie bureau voor sportieve en recreatieve evenementen. 


\section{List of publications}

Full papers relevant to this thesis

- Roos W, Eymann E, Symannek M, Duppenthaler J, Wodzig KWH, Pelsers MMAL, et al. Monoclonal antibodies to human heart fatty acid-binding protein. $J$ Immun Methods 1995; 183:149-53.

- Wodzig KWH, Pelsers MMAL, van der Vusse GJ, Roos W, Glatz JFC. One-step enzyme-linked immunosorbent assay (ELISA) for serum fatty acid-binding protein. Ann Clin Biochem 1996;33:1-6.

- Hermens WT, Pelsers MMAL, Mullers-Boumans ML, de Zwaan C, Glatz JFC. Combined use of markers of muscle necrosis and fibrinogen conversion in the early differentiation of myocardial infarction and unstable angina. Clin Chem 1998;44:890-2.

- Schreiber A, Soecht B, Pelsers MMAL, Glatz JFC, Börchers T, Spener F. Recombinant human heart-type fatty acid-binding protein as standard in immunochemical assays. Clin Chem Lab Med 1998;36:283-8.

- Sorichter S, Mair J, Koller A, Pelsers MMAL, Puschendorf B, Glatz JFC. Early assesment of exercise induced skeletal muscle injury using plasma fatty acid binding protein. Br J Sports Med 1998;32:121-4.

- Hoogenboom HH, Lutgerink JT, Pelsers MMAL, Rousch MJ, Coote J, Van Neer N, et al. Selection-dominant and non-accessible epitopes on cell-surface receptors revealed by cell-panning with a large phage antibody-library. Eur $J$ Bochem 1999;260:774-84.

- Pelsers MMAL, Bishop CM, Butler PJ, Glatz JFC. Fatty acid-binding protein content of heart and skeletal muscles of the migratory barnacle goose during development. $A$ J Physiol 1999;276:R637-43.

- Pelsers MMAL, Chapelle JP, Knapen M, Vermeer C, Glatz JFC. Influence of age, sex and day-today and within-day biological variation on plasma concentrations of fatty acid-binding protein and myoglobin in healthy subjects. Clin Chem 1999;45:441-3.

- Pelsers MMAL, Lutgerink J, Nieuwenhoven FA, Tandon NN, van der Vusse GJ, Arends JW, et al. A sensitive immunoassay for fatty acid translocase (CD36) using phage antibodies selected on cell transfectants: abundant presence of FAT/CD36 in cardiac and red skeletal muscle and upregulation in diabetis. Biochem J 1999;3:40714.

- Aartsen WM, Pelsers MMAL, Hermens WT, Glatz JFC, Daemen MJAP, Smits JFM. Heart fatty acid-binding protein and cardiac troponion $\mathrm{T}$ plasma concentrations as 
markers for myocardial infarction after coronary ligation in mice. Pfluglers Arch 2000;439:416-22.

- Pelsers MMAL, Morovat A, Alexander GJM, Hermens WT, Trull AK, Glatz JFC. Liver fatty acid-binding protein as a sensitive serum marker of acute hepatocellular damage in liver transplants. Clin Chem 2002;48:2055-7.

- Gok M, Pelsers, MMAL Glatz JFC, Bhatti AA, Shenton B, Peaston R, et al. Comparison of perfusate activities of gluthathione S-transferase, alanine aminopeptidase and fatty acid-binding protein in the assessment of non-heart-beating donor kidneys. Ann Clin Biochem 2003;40:252-8.

- Gok M, Pelsers MMAL, Glatz JFC, Shenton BK, Buckley PE, Cornell C, et al. Creatinine clearance and viability of biomarkers of machine perfused non-heart-beat donors: is there a correlation? Transplant Proc 2003;35:768.

- Gok M, Pelsers MMAL, Glatz JFC, Shenton BK, Buckley BK, et al. Do tissue damage markers used to assess machine perfused NHBD kidneys predict long term renal function post-transplant? Clin Chim Acta 2003;338:33-43.

- Gok M, Pelsers MMAL, Glatz JFC, Shenton B, Peaston R, Cornell C, et al. Assesment of machine perfused NHBD kidneys using two biomarkers of renal ischemia. Clin Chem 2003;49:172-5.

- Pelsers MMAL, Namiot Z, Kisiekewski W, Namiot A, Januszkiewicz M, Hermens WT, et al. Intestinal-type and liver-type fatty acid-binding protein in the intestine: tissue distribution and clinical utility. Clin Biochem 2003,36:529-535.

- Van der Voort D, Pelsers MMAL, Korf J, Hermens WT, Glatz JFC. Development of a displacement immunoassay for human heart-type fatty acid-binding protein in plasma: the basic conditions. Biosens Bioelectron 2003;19:465-71.

- Pelsers MMAL, Hanhoff T, van der Voort D, de Kruijk J, Twijnstra A, Rudzinski W, et al. Tissue specific types of fatty acid-binding proteins, B- and H-FABP, as novel markers for detection of brain injury. Clin Chem, in press.

- Pelsers MMAL, Hermens WT, Glatz JFC. Performance of FABP as plasma marker of tissue injury. Invited review for Clin Chim Acta, in press. 


\section{Awards}

- Bursary Project from the Local Scientific Committee for presentation of a poster entitled "Liver fatty acid-binding protein as a sensitive serum marker of acute hepatocellular damage in liver transplants", Euromedlab, Prague, June 2001.

- Life Sciences Limburg "Innovation Poster award "Fatty acid-binding protein: a plasma marker for the early detection of tissue necrosis" Cells at work, Euregional Life Sciences Conference, Maastricht, November 2002.

- Poster award for "Tissue specific types of fatty acid-binding proteins, B- and HFABP, as novel markers for detection of brain injury". Euregio Congress of Clinical Chemistry and Laboratory Medicine, Aken, October 2003.

- Winner Xpert Learning Xperience, an entrepeneur start-up simulation game, Technopartner, Vaals, May 2004. 